Universidade de São Paulo

Faculdade de Arquitetura e Urbanismo

Programa de Pós Graduação em Arquitetura e Urbanismo

\title{
Acessibilidade à Paisagem
}

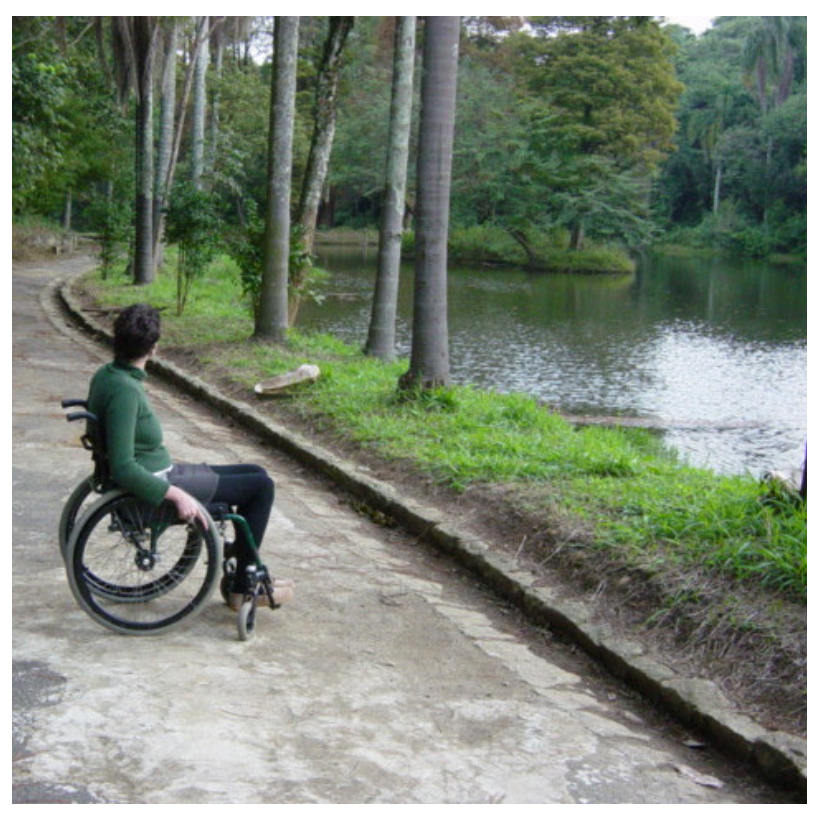




\section{Acessibilidade à Paisagem}

Daniela Vaz

Orientador: Fábio Mariz Gonçalves

A presente dissertação destina-se à Faculdade de Arquitetura de Urbanismo da Universidade de São Paulo para obtenção do grau Mestre.

Área de concentração: Paisagem e Ambiente

São Paulo, fevereiro de 2008. 
AUTORIZO A REPRODUÇÃO E DIVULGAÇÃO TOTAL OU PARCIAL DESTE TRABALHO, POR QUALQUER MEIO CONVENCIONAL OU ELETRÔNICO, PARA FINS DE ESTUDO E PESQUISA, DESDE QUE CITADA A FONTE.

E-mail: dani_vaz@yahoo.com

\begin{tabular}{|l} 
Vaz, Daniela \\
V393a Acessibilidade à paisagem / Daniela Vaz. - - São Paulo, \\
2008. \\
263 p. : il. \\
Dissertação (Mestrado - Área de Concentração: Paisagem e \\
Ambiente) - FAUUSP. \\
Orientador: Fábio Mariz Gonçalves. \\
1.Acessibilidade ao meio físico 2.Espaços livres 3.Espaço \\
público 4.Arquitetura paisagística (Projetos) I.Título \\
CDU 72-056.26 \\
\hline
\end{tabular}




\section{Dedicatória}

Dedico este trabalho

Ao meu filho, Mateus, que em tão pouco tempo mudou completamente o rumo da minha vida.

Aos meus pais pelo esforço, pelo empenho e por acreditar que sempre é possível chegar mais longe. 


\section{Agradecimentos}

Aos meus pais, Romilda e Henrique.

Aos meus irmãos Raquel e Felipe.

Ao Professor Dr. Fábio Mariz Gonçalves, orientador do trabalho.

Às professoras Dra. Catharina Cordeiro Lima e Dra. Sheila Walbe Ornstein, pelas contribuições ao longo do trabalho e na Banca de Qualificação.

Ao Arquiteto Fábio Augusto Toscano Bellini pelas boas idéias e pelo companheirismo.

À Professora Maria Aparecida das Chagas por todo acompanhamento acadêmico e revisões textuais.

À Doutora Fátima de Oliveira Oliver, à Neuraci de Souza Moreno, à Engenheira Maria Clara Barros Santos, à Doutora Maria Elisabete Lopes e à Mestra Silvana Serafino Cambiaghi, as quais auxiliaram no encaminhamento das coletas de dados e análises diversas.

Ao Sr. Hércules Vergari, gerente de manutenção e Sr Herbert Klassa, gerente de gestão de pessoas do Parque Playcenter.

À Arquiteta Cristina T. S. Laiza da Empresa Municipal de Urbanização (EMURB).

Ao Arquiteto José Renato Soilbelmann Melhem coordenador do Programa Passeio Livre da Prefeitura de São Paulo.

À Guarda Civil Municipal de São Paulo, pelo apoio durante às visitas à Praça da Sé. 


\section{Resumo}

Nesta pesquisa o objetivo é trazer à tona a discussão sobre a acessibilidade universal, no espaço livre projetado. Buscando evidenciar dificuldades encontradas não só por pessoas com deficiências, mas também por toda sociedade, no uso do território. Focando na sensibilização dos profissionais, especialmente arquitetos paisagistas.

Este estudo busca discutir aspectos da concepção de projetos que, embora existam legislações e normas que tratem da questão de forma bastante ampla, a prática da construção da cidade "real" não garante os direitos adquiridos legalmente.

Os espaços livres de uso público são locais onde se desenvolve a cidadania e têm fundamental importância no processo de inclusão social.

Alguns espaços construídos, embora de acordo com a norma (NBR 9050 - Acessibilidade a Edificações, Mobiliário, Espaços e Equipamentos Urbanos), muitas vezes, não atende à pessoa com deficiência ( $P C D)$, porque o meio externo não é acessível. 


\section{Abstract}

In this research the purpose is to bring to light the discussion about universal accessibility on the designed free space, by trying to make evident the difficulties found not only by the disabled, but also by the entire society. It focuses on the professional, especially architects and landscape architects.

This study tries to argue different aspects of the project conception which, even though there are laws and norms that handle the issue in an ample way, the practice of the "real" city construction does not guarantee the rights acquired legally.

The public free spaces are spaces where the citizenship is developed and are really important in the process of social inclusion.

Some of the built spaces sometimes doesn't consider the disabled, although they follow the law (NBR 9050), because the exterior is not accessible. 


\section{Lista de figuras}

FIGURA 1 - RAMPA INCLUSA SOBRE A ESCADA - INSERÇÃO APÓS A CONCEPÇÃO DO PROJETO. O RESULTADO FINAL NÃO ATENDE CORRETAMENTE AO CADEIRANTE, POIS NÃO POSSUI INCLINAÇÃO CORRETA NEM CORRIMÃOS, TAL COMO ESTÁ PODE OCASIONAR ACIDENTES, ESPECIALMENTE EM IDOSOS, CRIANÇAS E PESSOAS COM DEFICIÊNCIA VISUAL (ESTABelecimento na Rua Avanhandava).

FigURA 2 - SiSTEMA PARA O ACESSO UnIVERSAL

FiguRA 3 - PASSEIO dE MANSKI Foto: GEHL; GEMZOE, 2002.

FigURA 4 - AUDITORIUM FORECOURT FoUTAIN - LAWRENCE HALLPRIN, 1970.

Figura 5 - TSuKuba CENTRE SQUare. Foto: GEHL; GEMZOE, 2002.

FiguRA 6 - CLOUD GARDENS. Foto: GEHL; GEMZOE, 2002.

Figura 7 - Ponto de PARADA EM CURITIBA. Foto: GEHL; GEMZOE, 2002.

Figura 8 - Pionner Courthouse Square. Foto: GeHL; GEMZOE, 2002.

Figura 9 - PionNer Courthouse Souare. Foto: GeHL; GeMZOE, 2002.

FIGURA 10 - O DEMOLIDOR REPRESENTA BEM O QUE SACKS PENSA SOBRE A COMPENSAÇ̃̃O DA DEFICIÊNCIA.

Figura 11 - Gráfico Pessoas com DeficiênCIAS No BRASIL

Figura 12 - Gráfico Pessoas com DeficiênCia no Brasil

FigURA 13 - GRÁFICO TIPOS DE DEFICIÊNCIAS NO BRASIL

FiguRA 14 - PRINCÍPIO 1 - IgUALDADE DE USO

FiguRA 15 - PRINCÍPIO 2 - FLEXIBILIDADE DE USO

FiguRA 16 - PRINCÍPIO 3 - SimPLICIDADE E INTUIÇÃO

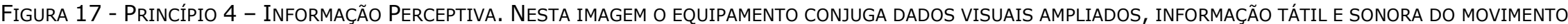
REALIZADO.

Figura 18 - PrincíPIO 5 - TOLERÂNCIA AO ERro

FIGURA 19 - PRINCÍPIO 6 - BAIXO ESFORÇO FÍSICO

Figura 20 - Princípio 7 - Dimensão e EspaÇo Para AproximaÇ̃̃o e Uso

Figura 21 - Foto: EMURB - PraÇa da SÉ. RequalificaÇÃo do EspaÇo URbano. Apresentação em Power Point.

FiguRA 22 - PRAÇA DA LIBERDADE - ACESSO À PLATAFORMA DO METRÔ. OBSERVA-SE A UTILIZAÇÃO dE PISO TÁTIL DIRECIONAL PARA ORIENTAÇÃO DE PESSOAS COM DEFICIÊNCIA

VISUAL, PORÉM OS CORRIMÃOS NÃO ESTÃO INSTALADOS EM 2 ALTURAS E NÃO EXISTE OPÇÃO AO ACESSO DE CADEIRANTES PELA PRAÇA.

Figura 23 - PraÇa dA SÉ. DisPonível EM:

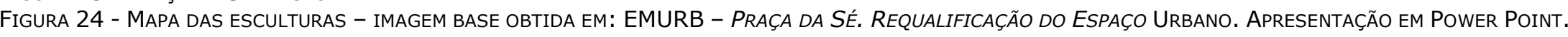

FigURA 25 - "CONDOR" - ESCULTURA DE BRUNO GIORGI.

Figura 26 - PRAÇA DO AUDITÓRIUM ForeCOURT DE LAWRENCE HALPRIN, EUA, 1961.

Figura 27 - Praça do Audiórium Forecourt de LaWrence halprin, EUA, 1961.

Figura 28 - PRAÇA DA SÉ. DisPonível EM:

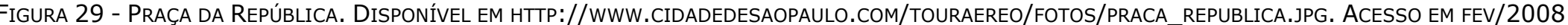

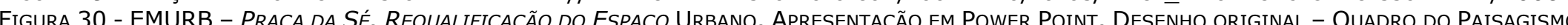
QUAPÁ

Figura 31 - Mapa dos arRedores da estação SÉ do Metrô - Metrô

Figura 32 -Imagem - EMURB - PraÇA da Sé. RequalificaÇão do EspaÇo URbano. Apresentação em Power Point. 
Figura 33 - EMURB - PraÇa da Sé. RequalificaÇÃo do EspaÇo Urbano. Apresentação em Power Point. Canteiro com densa VegetaÇÃo.

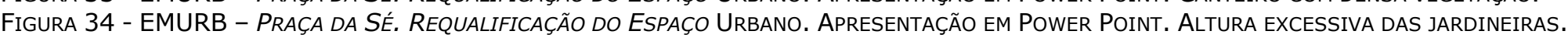

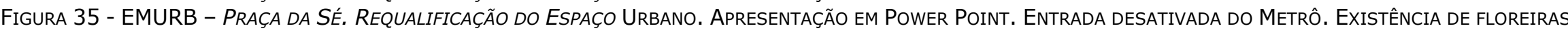
ALTAS E OCUPAÇÃO POR MORADORES DE RUA.

FIGURA 36 - EMURB - PRACA DA SÉ. REQUALIFICACÃO DO ESPAÇO URBANO. APRESENTAČ̃O EM POWER POINT. ESCADARIAS. NãO EXISTIAM ROTAS ACESŚ́VEIS.

Figura 37 - Planta da PRAÇA. PROJETO DE CONSTRUÇÃo E DEMOLIÇÃo - EMURB 89

FiguRA 38 - RAMPA EM CONSTRUÇÃo NA PRAÇA DA SÉ.

FIGURA 39 - FOTO DA RAMPA DE ENTRADA DA ESTAÇ̃̃O.

FIGURA 40 - PASSARELA SOBRE O FOSSO DO METRÔ.

Figura 41 - Construção de uma das RAMPAS dA ENTRAdA REATIVAda do Metrô.

Figura 42 - GRELHA dE VENTILAÇÃo do METRô.

Figura 43 - Obras de CONStRuÇão de novas floreiras no eixo leste-Oeste da PraÇA.

Figura 44 - Rebaixamento de FLOREIRAS EM FRENTE AO PALÁCiO DA JUSTIÇA.

FigURA 45 - CONSTRUÇÃo DA PASSARELA SOBRE O ESPELHO D'ÁGUA NO CENTRO DA PRAÇA DA SÉ.

FIGURA 46 - OBSERVAÇÃO PANORÂMICA DA PRAÇA EM OBRAS, COM AS FLOREIRAS REBAIXADAS.

FIGURA 47 - RAMPA DO ACESSO APÓS A REATIVAÇÃO DA ENTRADA DA ESTAÇÃO SÉ DO METRÔ.

Figura 48 - RAMPA DE ENTRADA PARA O ACESSO REATIVADO DO METRÔ. OBSERVAR PISO TÁtil dE ORIENTAÇÃo. 98

Figura 49 - PAssarela sobre o fosso da EstaÇão SÉ de Metrô.

FIGURA 51 - IMAGEM DOS PISOS TÁTEIS - INFORMATIVO TÉCNICO N.o 14 - USP LEGAL

Figura 50 - MURETA DE CANTEIRO ALAGADO. OBSERVAR PISO TÁTIL. 99

Figura 52 - CANTEIROS ALAGAdOS, JUNTO AO ESPELHO D'ÁGUA. OBSERVAR, AO FUNDO, TRECHO COM PISO INACABADO. 100

100

Figura 54 - RAMPA DE ACESSO AO EIXO LESTE-OESTE, JUNTO À RUA ANITA GARIBALDI.

FIGURA 55 - ESCADARIA NO EIXO NORTE-SUL, PRÓXIMO À RUA ANITA GARIBALDI. 101

Figura 56 - CALÇADA DA RUA ANITA GARIBALDI, JUNTO À PRAÇA, SENTIDO NORTE.

FigURA 57 - CALÇADA DA RUA ANITA GARIBALDI, JUNTO À PRAÇA, SENTIDO SUL. 102

Figura 58 - TRAVESSIA dA RUA ANITA GARIBALDI, PRÓXIMO AO PALÁCIO DA JUSTIÇA. 103

FIGURA 59 - PARQUE OIZUMI RYOKUCHI, OSAKA - JAPÃO. CADEIRANTE COM DEFICIÊNCIA VISUAL TOCANDO O LAGO. 108

FiguRA 60 - IMAGEM: CARTILHA PASSEIO LIVRE. DiSPONÍVEL EM: HTTP://WW2.PREFEITURA.SP.GOV.BR/PASSEIOLIVRE/INDEX.ASP

Figura 61 - CALCADA DA RUA OSCAR FREIRE. 114

Figura 62 - TRAVESSia NA RUA AVANHANDAVA.

FiguRA 63 - Foto: HEUDES REgIS 127

FigURA 64 - Foto: HEUDES REgIS 127

Figura 65 - Calçada da Avenida Eusébio Matoso em direÇÃo ao CEntro. À direita, AlÇA de acesso da Avenida Marginal do Rio Pinheiros. 129

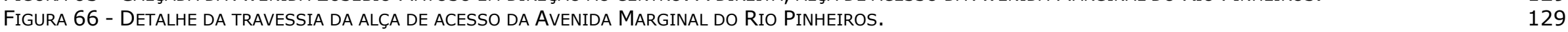

Figura 67 - CALÇADA DO BANCO ITAÚ.

FIGURA 68 - PASSEIO PÚBLICO PADRONIZADO E PERCURSO LIVRE DE OBSTÁCULOS. 130

Figura 69 - Acesso à Av. Eusébio Matoso. Rua SÃo Columbano, esquina com o Shopping Center Eldorado. 131

Figura 70 - CRuZamento da AV. Rebouças COM a Rua JoÃo Moura. 131

Figura 71 - CRuzamento da Av. Rebouças com Av. Brasil.

Figura 72 - Cruzamento da Av. Rebouças com Rua Joaquim Antunes. 
Figura 73 - Cruzamento da Av. Rebouças com Rua Henrique Schaumann.

Figura 74 - CRuzamento da Av. Rebouças COM Av. Brasil.

Figura 75 - Acesso da Av. Rebouças com a Av. Eusébio Matoso

Figura 76 - RAMPA BEM EXECUTAdA NA ESOUINA dA RUA DES. JoAQUim CELIDONio.

Figura 77 - Cruzamento da Av. Rebouças com a Rua JoÃo Moura.

Figura 78 - Cruzamento da Av. Rebouças com a Av. Pedroso de Moraes.

Figura 79 - Cruzamento da Av. Rebouças com a Av. Pedroso de Moraes.

Figura 80 - Cruzamento da Av. Rebouças com a Rua JoÃo Moura.

Figura 81 - ORELHÃo NA CALÇADA da AV. ReBOUÇAS.

Figura 82 - ORELHÃo, CRUZAMENTO dA RUA MARTE COM Av. EusÉbio Matoso.

FIGURA 83 - NBR 9050/2004 - SINALIZAÇÃO TÁTIL PARA VOLUMES SUSPENSOS.

FIGURA 84 - NBR 9050/2004 - BENGALA DE RASTREAMENTO PARA PESSOAS COM DEFICIÊNCIA VISUAL.

134

Figura 85 - Ponto de ÔNibus na Av. Eusébio Matoso, em FRENTE AO SHOPPing Center Eldorado. 136

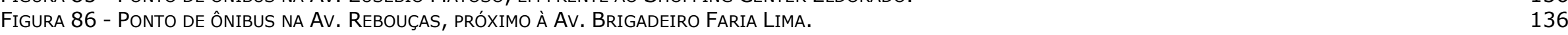

Figura 87 - DETALHE dE ABRIgO DE ÔNIBUS.Foto: FÁBIO A.T. BELLINI

Figura 88 - Av. REBOUÇAS, PRÓXIMO À RUA OSCAR FREIRE, SENTIDO CENTRO. EMENDAS NO PISO DESRESPEITANDO O ORIGINAL.

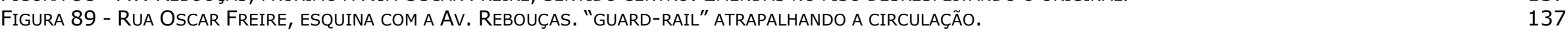

Figura 90 - Obras do Metrô, NA AV. RebOUÇAS, PRÓXIMO À Rua OSCAR FrEIRE. INTERVENÇÕES NA CALÇADA DIFICULTANDO A CIRCULAÇÃO.

FigURA 91 - ESOUINA dA RUA OSCAR FREIRE COM A Av. REBOUÇAS. EMENDAS NO PISO E MOBILIÁRIO URBANO, DIFICULTANDO A CIRCULACÃO, 137

Figura 92 - Esquina da Av. Eusébio Matoso com a Rua Cardeal Arco Verde. Posto de gasolina, em frente ao Shopping Center Eldorado.

Figura 93 - POSTO NA AV. REBOUÇAS, PRÓXIMO À RUA JOAQUIM ANTUNES.

Figura 94 - AdEQUAÇÃo ENTRE A GARAgEM DO LOTE E A CALÇADA PADRONIZADA.

FIGURA 95 - ESTACIONAMENTO DO BANCO DO BRASIL, JUNTO À CALÇADA REFORMADA.

Figura 96 - Av. RebouÇas, PRÓXimo à Alameda Gabriel Monteiro DA Silva. 140

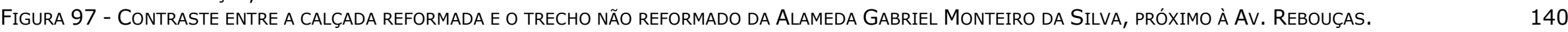

FIGURA 98 - NBR 9050/2004 - CORRIMÃO EM RAMPAS 141

Figura 99 - PASSARELA PRÓXIMA À Ponte EUSÉbio MATOSO.

Figura 100 - EM FRENTE AO SHOPPING CENTER ELDORADO, PONTO DE ÔNIBUS E AO FUNDO, PASSARELA DE PEDESTRES.

Figura 101 - Av. REBOUÇAS E PONTO DE ÔNIBUS VISTOS DE CIMA DA PASSARELA DO HOSPITAL DAS CLÍNICAS. 142

Figura 102 - ESCADARIA DE ACESSO, SOB A PASSARELA DO HOSPITAL DAS ClíNICAS (Av. ReBOUÇAS).

Figura 103 - UM DOS ACESSOS À PASSARELA DO HOSPITAL DAS CLÍNICAS (AV. REBOUÇAS, SENTIDO CENTRO). 143

FigURA 104 - CARRO ESTACIONADO, INVADINDO A CALÇADA DA AV. REBOUÇAS. 144

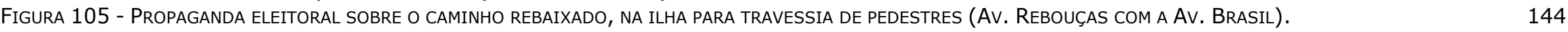

FIGURA 106 - CARRO ESTACIONADO SOBRE A CALÇADA, IMPEDINDO A CIRCULAÇ̃̃O DE PEDESTRES.

FIGURA 107 - CAMINHÃO ESTACIONADO, INVADINDO A CALÇADA. 144

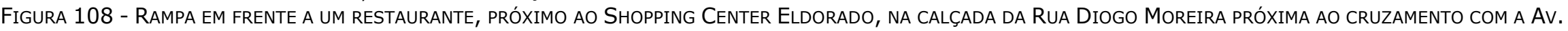

EUSÉBIO MATOSO.

FIGURA 109 - NBR 9050/2004 - REBAIXOS DE CALÇADAS

FIGURA 110 - NBR 9050/2004 - REBAIXOS DE CALÇADAS

Figura 112 - Início do tReCho Reformado de calçada. Esouina Rua dos Pinheiros com a Rua Mourato Coelho. 
Figura 113 - Calçada da Rua dos Pinheiros. Demarcação das faixas de uso.

Figura 114 - RUA DOS PinHEIROS, RAMPA DiRECIONANDO PARA O CRUZAMENTO COM A RUA CAPITÃo ANTÔNIO ROSA.

FIGURA 115 - RAMPA E FAIXA DE PEDESTRES - RUA DOS PINHEIROS, EM FRENTE À RUA TECAINDÁ.

Figura 116 - CALÇAdA NA RUa dos PinHeIROS. ObSERVAR TAMPO NA FAIXA LIVRE E DESNÍVEIS PARA ENTRADA DE AUTOMÓVEIS.

FiguRA 117 - PASSEIO ESTREITADO PELAS OBRAS DO METRÔ E PELO USO DE MOBILIÁRIO URBANO (LIXEIRAS).

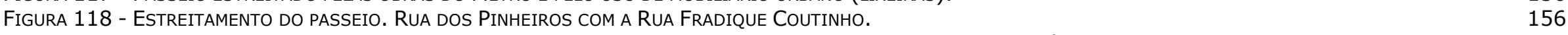

Figura 119 - Cruzamento da Rua dos Pinheiros com a Rua Fradique Coutinho, FeChado Pelas obras do Metrô. 156

Figura 120 - CalÇADA NA ESQUina do ENCONTRO DA RUA MATHEUS GROU COM A RUA DOS Pinheiros. 157

Figura 121 - ESTREITAMENTO do PASSEIO PELAS OBRAS DO METRÔ. OBSERVAR AUTOMÓVEL INVADINDO A CALÇADA NA FAIXA DE ACESSO AO LOTE. 157

Figura 122 - PASSEIO Na RUa dos Pinheiros. OBSERVAR FLOREIRA E RAMPA DE ACESSO AO IMÓVEL OBSTRUINDO A FAIXA LIVRE. 158

Figura 123 - Obras do Metrô ocupando a calçada da Rua dos Pinheiros, sentido Av. Marginal do Rio Pinheiros.

Figura 124 - RUA DOS PiNHEIROS. OBSERVAR INTERFACE ENTRE O PASSEIO E OS LOTES.

FiguRA 125 - RUA DOS PINHEIROS. CALÇADA EM CIMENTO RÚSTICO E LIXEIRAS.

Figura 126 - RUA dos PinHEIROS COM A RUA CAPITÃo ANTONNIO ROSA. Fim DO TRECHO REFORMAdo. 160

FIGURA 127 - NBR 9050/2004 - RAMPAS DE ACESSO PROVISÓRIO 163

FIGURA 128 - RUA JoÃo CACHOEIRA, ESQUINA COM A RUA JESUÍNO ARRUDA.

Figura 129 - CALÇADA ALARGADA. BANCOS E LOCALIZADOR DE LOJAS, CRIAM AMBIENTES DE DESCANSO. 167

Figura 130 - Mobiliário uRbano na calçada da Rua JoÃo CACHOEIRA.

FIGURA 131 - DETALHE DE LOCALIZADOR DE LOJAS. 168

FIGURA 132 - "ILHAS DE DESCANSO" E MOBILIÁRIO URBANO PRÓPRIO.

FIGURA 133 - NBR9050/2004 - ASSENTOS FIXOS 169

FIGURA 134 - DETALHE DA IMPLANTAÇÃO DE BANCOS. 169

FIGURA 135 - RUA JOÃO CACHOEIRA - ORELHÃO. 170

FIGURA 136 - NBR 9050/2004 - SINALIZAÇÃO TÁTIL DE ALERTA PARA OBSTÁCULOS SUSPENSOS. 170

Figura 137 - DETALHE DE ORELHÃo, RUA JoÃo CACHOEIRA.

FIGURA 138 - RUA JoÃo CACHOEIRA, ESQUINA COM A RUA TABAPUÃ. 171

Figura 139 - RUA JOÃO CACHOEIRA, ESQUINA COM A RUA JOAQUIM FLORIANO.

Figura 140 - RUA JoÃo CACHOEIRA, ESQUINA COM A RUA LEOPOLDO C. DE MAGALHÃES JR..

FIGURA 141 - RUA JoÃo CACHOEIRA, ESQUINA COM A RUA TABAPUÃ.

FIGURA 142 - NBR9050/2004 - REBAIXAMENTO DE ESOUINAS.

FIGURA 143 - RUA JoÃo CACHOEIRA, ESQUINA COM A RUA IAIÁ. 172

FIGURA 144 - TAMPOS DE CONCESSIONÁRIAS NA CALÇADA DA RUA JOÃO CACHOEIRA. 173

FIGURA 145 - VENDEDOR AMBULANTE ESTABELECIDO NA FAIXA DE SERVIÇOS. 173

FiguRA 146 - ESTABELECIMENTO, NA RUA JoÃo CACHOEIRA, UTILIZA A FAIXA DE ACESSO DO LOTE PARA COLOCAR MOSTRUÁRIO.

FIGURA 147 - BINGO, NA RUA JOÃO CACHOEIRA, UTILIZA A FAIXA DE ACESSO DO LOTE PARA COLOCAR MOBILIÁRIO. 174

FIGURA 148 - RUA JOÃO CACHOEIRA - RESTAURANTE COLOCA MESAS NA FAIXA DE ACESSO AO LOTE.

FIGURA 149 - PONTO DE TAXI NA RUA JOÃO CACHOEIRA.

FigURA 150 - BANCA DE JORNAL NA FAIXA DE ACESSO AO LOTE, OCUPANDO PARTE DA FAIXA LIVRE.

FIGURA 151 - BANCA DE JORNAL OCUPANDO, CORRETAMENTE, A FAIXA DE SERVIÇO.

177

Figura 153 - EstabeleCimentos na Rua JoÃo CACHOEIRA NÃo SE ADEQUARAM A ACESSibilidade. 177

Acessibilidade à Paisagem Página 11


Figura 154 - VAga PARA PCD, RUa JoÃo CACHOEIRA. SinAlizAÇÃo VERTICAL IMPEDINDO ABERTURA DE PORTA DOS AUTOMÓVEIS.

Figura 155 - VAGA PARA PCD, RUA JOÃo CACHOEIRA. ÁRVORE IMPEDINDO ABERTURA DE PORTA DOS AUTOMÓVEIS.

FIGURA 156 - NBR 9050/2004 - CONFIGURAÇÃO DE VAGAS PARA PCDS

FIGURA 157 - MOTO OCUPANDO A VAGA DE PCDS.

FIGURA 159 - LIMITE DAS INTERVENÇÕES - RUA LEOPOLDO COUTO MAGALHÃES JUNIOR.

FIGURA 160 - IMAGEM BASE RETIRADA DO SITE WWW.PLAYCENTER.COM.BR

FIGURA 161 - SKY COASTER IMAGEM DISPONÍVEL EM: WWW.PLAYCENTER.COM.BR

FIGURA 162 - BOOMERANG

FIGURA 163 - ARVORISMO IMAGEM DISPONÍVEL EM: WWW.PLAYCENTER.COM.BR

FIGURA 164 - BARCA VIKING. IMAGEM DISPONÍVEL EM: WWW.PLAYCENTER.COM.BR

FIGURA 165 - WAVE SWINGER. IMAGEM DISPONÍVEL EM: WWW.PLAYCENTER.COM.BR

FigURA 166 - WIND STORM. IMAGEM DISPONÍVEL EM: WWW.PLAYCENTER.COM.BR

FIGURA 167 - MAGIC MOTION. IMAGEM DISPONÍVEL EM: WWW.PLAYCENTER.COM.BR

FIGURA 168 - RODA GIGANTE. IMAGEM DISPONIVEL EM: WWW.PLAYCENTER.COM.BR

FigURA 169 - INSTALAÇÃO DAS NOITES DO TERROR - PLAYCENTER.

FIGURA 170 - DISPONÍVEL EM:

FIGURA 171 - FOTO MONTAGEM. BASE GEGRAN

FIGURA 172 - IMPLANTAÇÃO DO PAROUE PLAYCENTER - ENTORNO.

FIGURA 173 - ESQUEMA DE LINHAS DE TREM.

FIGURA 174 - ÔNIBUS DO PARQUE SEM ADAPTAÇÃO PARA CADEIRANTES.

FIGURA 175 - ÔNIBUS DO PARQUE TRAZENDO VISITANTES.

Figura 176 - Plano Diretor para 2007, FORNECIDO PELO PlayCENTER.

FIGURA 177 - TURBO DROP.

Figura 178 - CARROSSEL CAVALINHOS - DisPoníVEL EM:

FIGURA 179 - BOOMERANG

Figura 180 - Entrada do Playcenter. Vista interna.

Figura 181 - Catracas E detectores de metal na entrada do Playcenter. Vista interna.

Figura 182 - BilHeterias do PARque.

FIGURA 183 - CONTRASTE ENTRE O PISO REFORMADO E O ANTIGO.

FigURA 184 - QUIOSQUE DE ALIMENTAÇÃO.

Figura 185 - BALCÃo DA ATRAÇÃo. OBSERVAR A RELAÇÃo dA ALTURA EM RELAÇÃo Às CRIANÇAS.

FIGURA 186 - NBR 9050/2004 - BALCÕES

FiguRA 187 - PraÇA dE ALIMENTAÇÃo do PlayCENTER.

FiguRA 188 - MOBILIÁRIO DA PRAÇA DE ALIMENTAÇÃo DO PLAYCENTER.

Figura 189 - Desenível ENTRE A PRAÇA DE ALIMENTAÇÃo E A CiRCULAÇÃo do PARQUE. 217

FIGURA 190 - RAMPA IMPROVISADA PARA PCDS.

FIGURA 191 - ENTRADA DE SANITÁRIO.

FIGURA 192 - BALCÃO DE LANCHONETE DA PRAÇA DE ALIMENTAÇÃO.

FIGURA 193 - ENTRADA DE SANITÁRIO.

FIGURA 194 - ENTRADA DE SANITÁRIOS. OBSERVAR ENTRADA PARA SANITÁRIO FAMILIAR. 
FIGURA 195 - SINALIZAÇÃO DE SANITÁRIO ADAPTADO.

FiguRA 196 - PIA ADAPTADA DENTRO DE CABINE ADAPTADA. OBSERVAR SIFÃo DESPROTEGIDO.

FIGURA 197 - PIA DE SANITÁRIO. OBSERVAR O TRECHO DO TAMPO REBAIXADO.

FIGURA 198 - SANITÁRIO ADAPTADO.

FIGURA 199 - NBR9050/2004 - BARRAS DE APOIO PARA VASOS SANITÁRIOS

FIGURA 200 - NBR9050/2004 - PIA EM CORTE E EM VISTA, ALCANCES E ALTURAS 222

FIGURA 201 - NBR9050/2004 - POSICIONAMENTO DE ESPELHOS PARA CADEIRANTES 222

FIGURA 202 - ESCADA SEM SINALIZAÇÃO TÁTIL DE ALERTA E CORRIMÃOS. 223

FIGURA 203 - ESCADA DE BRINQUEDO COM CORRIMÃOS IRREGULARES. 223

FIGURA 204 - ESCADA DE BRINQUEDO, SEM CORRIMÃO. 223

FIGURA 205 - ESCADA SEM CORRIMÃO, SEM PISO TÁTIL E COM DEGRAUS IRREGULARES. 223

FIGURA 206 - ESCADA COM CORRIMÃOS FORA DE NORMA, SEM SINALIZAÇÃO TÁTIL E SEM ESPELHOS. 223

FIGURA 207 - ESCADARIA DE ACESSO AO BRINQUEDO. FALTA SINALIZAÇÃO TÁTIL. 223

FIGURA 208 - RAMPA IRREGULAR, SEM CORRIMÃO E COM UM DEGRAU NO PERCURSO. 224

224

FIGURA 210 - NBR9050/2004- RAMPAS E CORRIMÃOS 224

FIGURA 211 - RAMPA SEM PISO TÁTIL DE ALERTA, COM CORRIMÃOS IRREGULARES. 224

FIGURA 212 - RAMPA LATERAL À RAMPA, SEM SINALIZAÇÃO TÁTIL E CORRIMÃO. 224

FIGURA 213 - ENTRADA E ESPERA, DE BRINQUEDO, NO MESMO NÍVEL DO PISO.

FIGURA 214 - ENTRADA DE BRINQUEDO INFANTIL, EM NÍVEL COM O PISO. 225

FIGURA 215 - WAVE SWINGER. BRINQUEDO COM ASSENTOS INACESSÍVEIS. 226

FIGURA 216 - BARCA VIKING. BRINQUEDO COM ASSENTOS INACESSÍVEIS.

FIGURA 219 - NBR 9050/2004 - SINALIZAÇÃO HORIZONTAL E VERTICAL DE VAGAS PARA PCDS. 227

FIGURA 217 - PORTÃO DE ENTRADA DO ESTACIONAMENTO DO PLAYCENTER. 227

FIGURA 218 - VAGAS PARA VEÍCULOS DE CADEIRANTES. 227

FigURA 220 - PORTÃo DE ENTRADA E CALÇADA DO PARQUE. RUA INHAÚMA. 228

FiguRA 221 - CALÇADA DE ENTRADA DO PLAYCENTER. RUA INHAÚMA. 228

Figura 222 - Calçada do Parque. Av. Marginal do Rio Tietê. 228

Figura 223 - CALÇAdA LATERAL Ao estacionamento. RuA JosÉ Gomes FalcÃo.

Figura 224 - esouina da Rua José Gomes FalCÃo com a Av. Marginal do Rio Tietê.

Figura 225 - CALÇADA NA AV. MARQUÊS DE SÃo ViCENTE. 229

Figura 226 - PONTO de ÔNIBUS NA AV. MARQUÊS DE SÃo ViCENTE. 230

Figura 227 - Ponto de ÔNibus Av. MARginal do Rio Tietê. 230

FIGURA 228 - VAGA PARA VEÍCULO DE PCDS. 231

FigURA 229 - FALA DE MANUTENÇÃO NO PISO. ACESSO DO ESTACIONAMENTO PARA O PARQUE. 231

Figura 230 - ROTEIRO PERCORRIDO COM CADEIRANTE. MAPA BASE - PLANO DiRETOR PLAYCENTER - 2007.

FIGURA 231 - FICHA DE PERMISSÃO PARA UTILIZAÇÃO DE BRINQUEDOS POR PCDS 233

FIGURA 232 - CADEIRANTE ENTREGANDO FICHA NO BALCÃO DE INFORMAÇÕES. 233

FIGURA 233 - NBR 9050/2004 - BALCÕES 233

FIGURA 234 - RAMPA DE ENTRADA, AO LADO DAS CATRACAS. 234

FIGURA 235 - GRELHA A SER TROCADA.

Acessibilidade à Paisagem Página 13


FIGURA 236 - DETALHE DE VÃOS EM GRELHA.

FigURA 237 - GRELHA INSTALADA PARA A VEGETAÇÃO.

FIGURA 238 - GRELHA QUADRICULADA.

FIGURA 239 - LABIRINTO DE GRADIL E ESCADARIA DE ACESSO À BARCA VIKING.

FIGURA 240 - ACESSO PELA FILA DO SPLASH.

FIGURA 241 - FUNCIONÁRIO FAZENDO O TRANSLADO DA CADEIRANTE PARA A BARCA. ENTRADA PELA SAÍDA DO BRINQUEDO.

FigURA 242 - RAMPA REMOVÍVEL, DE MADEIRA, SENDO COLOCADA PARA PASSAGEM SOBRE O CANAL DO SPLASH. 236

FIGURA 243 - PONTE QUE LEVA À SAÍDA DA BARCA VIKING.

FIGURA 244 - RAMPA DE ACESSO AO SANITÁRIO.

FIGURA 245 - BEBEDOURO EM FRENTE AO SANITÁRIO.

FIGURA 246 - INSTALAÇÕES DENTRO DA CABINE, DE BANHEIRO, ADAPTADA.

FIGURA 247 - FUNCIONARIA

FIGURA 248 - CAMINHO PARA A RODAGIGANTE.

FIGURA 249 - ACESSO PARA RODA GIGANTE.

FIGURA 250 - QUIOSQUE DE VENDA DE ALIMENTOS.

FIGURA 251 - BURACOS NO PISO ANTIGO.

FIGURA 252 - LIMITE ENTRE O PISO REFORMADO E O ANTIGO.

FIGURA 253 - CAMINHO REFORMADO.

FIGURA 254 - APROXIMAÇÃO EM RELAÇÃO ÀS MESAS MÓVEIS, DA PRAÇA DE ALIMENTAÇÃO..

FigURA 255 - RAMPA ÍNGREME, SEM SINALIZAÇÃO E CORRIMÃOS, NO ACESSO À "CARCERAGEM DE MONSTROS".

FIGURA 256 - DETALHE DO ENCAIXE DA CADEIRA DE RODAS SOB A MESA.

FIGURA 257 - RAMPA DE PASSAGEM SOBRE O CÓRREGO.

FIGURA 258 - RAMPA DE PASSAGEM SOBRE O CÓRREGO.

FIGURA 259 - RAMPA DE PASSAGEM SOBRE O CÓRREGO.

FigURA 260 - RAMPA DE ACESSO AO MAGIC MOTION.

FIGURA 261 - RAMPA DO MAGIC MOTION.

FIGURA 262 - RAMPA DO MAGIC MOTION.

FIGURA 263 - INÍCIO DA SUBIDA DA RAMPA DO MAGIC MOTION.

FIGURA 264 - MAGIC MOTION.

FIGURA 265 - ACOMODAÇÕES PARA CADEIRANTES

FIGURA 266 - TRANSLADO DA CADEIRANTE PARA OS ASSENTOS DA PLATÉIA.
FIGURA 267 - CADEIRAS ARTICULADAS

FIGURA 268 - BALCÃO DO QUIOSQUE DE CHURRASCO.

FIGURA 269 - ENTRADA PARA O CARRINHO DA WIND STORM.

FIGURA 270 - PLATAFORMA DE EMBARQUE PARA A WIND STORM.

FIGURA 271 - RAMPA DE ACESSO À WIND STORM.

FIGURA 272 - RAMPA DE ACESSO À WIND STORM.

FIGURA 273 - ENTRADA DE SANITÁRIO.

FigURA 274 - DEGRAUS SOBRE A PLATAFORMA DO WAVE SWINGER.

FIGURA 275 - WAVE SWINGER.

FIGURA 276 - TRANSLADO DA CADEIRANTE PARA O WAVE SWINGER. 
FiguRA 277 - ESCADA DE ACESSO À PLATAFORMA DO WAVE SWINGER

FigURA 278 - MONITOR LEVANDO CADEIRANTE.

FiguRA 279 - VISITANTE do PARQUE, CADEIRANTE, EM FRENTE AOS DEGRAUS DE ACESSO AO SWING DANCE. 


\section{Abreviaturas}

ABNT - Associação Brasileira de Normas Técnicas

ADA - American with Disabilities Act

APO - Avaliação Pós-ocupação

AVAPE - Associação para Valorização e Promoção de Excepcionais

CEPAM - Centro de Estudos e Pesquisas de

Administração Municipal

CET - Companhia de Engenharia de Tráfego

COE - Código de Obras de Edificações do Município de São Paulo

CORDE - Coordenação Nacional para Integração da Pessoa Portadora de Deficiência

CPA - Comissão Permanente de Acessibilidade
CPTM - Companhia Paulista de Trens Metropolitanos

CTB - Código de Trânsito Brasileiro

EMURB - Empresa Municipal de Urbanização

EUA - Estados Unidos da América

FUNLAR - Fundação Lar Escola Francisco de Paula

HC - Hospital das Clínicas

IBGE - Instituto Brasileiro de Geografia e Estatística METRÔ - Companhia do Metropolitano de São Paulo NCSU - North Carolina State University

OMS - Organização Mundial da Saúde

ONU - Organização das Nações Unidas

PCD - pessoa com deficiência

SAV - Serviço de Atendimento ao Visitante 


\section{Sumário}

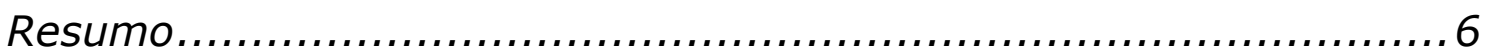

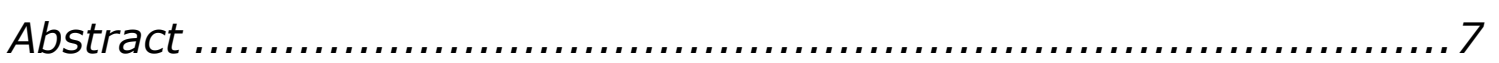

1. Apresentação .................................................... 18

1.1. Acessibilidade à paisagem.....................................22

1.2. Conceituação teórica ........................................... 29

1.3. Metodologia - aspectos gerais ................................. 34

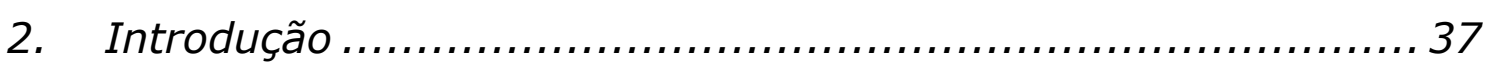

3. Desenho Universal ...........................................62

4. Estudo de caso - Praça da Sé ..........................................68 68

5. Estudo de caso - Calçadas....................................... 110

6. Estudo de caso - Playcenter .................................... 185

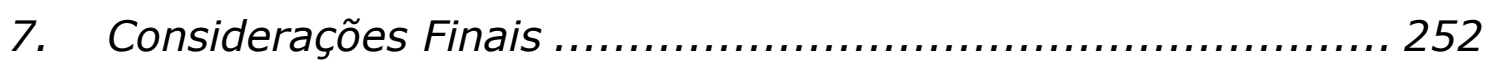

8. Referências ................................................... 256 


\section{Apresentação}

O presente estudo busca avaliar as condições de acessibilidade em espaços livres públicos ou espaços privados de uso coletivo. Apresentando não só análises técnicas e normativas dos espaços em si, mas também um panorama de como a questão está sendo incorporada aos projetos, com que qualidade, e em que medida ainda necessitam avançar.

Neste estudo, o espaço livre público é entendido como o espaço não edificado de uso público, ou seja, próprio de ações da vida pública.

Os espaços privados de uso coletivo são entendidos como os de propriedade privada, porém com características de "espacialidade social". Segundo Queiroga (in Discutindo a Paisagem, 2006), esses espaços são de uso de determinados grupos sociais específicos, como por exemplo, os shoppings centers e os clubes.

Serão analisados espaços livres públicos e espaços privados de uso coletivo, especialmente, porque não possuem o mesmo destaque que os espaços edificados, nas legislações e normas. 
Ao longo da história do desenho paisagístico o exercício do acesso para todos é uma prática difícil de ser encontrada e ainda hoje, grande parte dos projetos nacionais não leva em conta as pessoas com deficiência.

O direito à cidade também está longe de ser estendido a todos os cidadãos. Ao longo deste trabalho serão apresentados estudos de casos que demonstram que, mesmo em espaços onde existam projetos, as questões de acessibilidade e o acesso universal não estão incorporados à prática dos arquitetos. Quando encontradas soluções que atendem a estas questões, essas, geralmente, são insulares, não correspondendo a um conjunto de propostas, que possam viabilizar o acesso integrado, tão importante para medidas efetivas de inclusão.

A análise do espaço livre público voltado para a acessibilidade é um tema importante e pouco questionado nos trabalhos atuais. A acessibilidade só pode ser completa se tanto o meio construído como o espaço livre forem transformados. É no espaço livre público que se tem o acesso aos demais espaços, inclusive aos construídos. E é sobre esta questão que este trabalho objetiva trazer contribuição.

O estudo da acessibilidade tem avançado muito nos últimos anos no Brasil. Recentemente, autores têm apresentado trabalhos 
acadêmicos sobre o tema. A legislação e a Norma Brasileira de Acessibilidade (NBR 9050/2004), também nos apresentam um novo panorama. No entanto, ainda há muito a ser desenvolvido nesta área. Cidades históricas de relevo acidentado, edifícios históricos de difícil adaptação, áreas de preservação ambiental permanente, todos estes espaços são, por direito, de todos, porém novas soluções precisam ser apresentadas e representam desta forma um campo de estudo que se pode evoluir em grande proporção.

O objetivo deste trabalho é discutir as questões de acessibilidade, como forma de inclusão social, visando conquistar melhorias na qualidade de vida para todos.

Com base no estudo dos espaços livres públicos ou coletivos urbanos e nas questões de acessibilidade, analisar e comparar as condições na qualidade de vida, considerando aspectos da legislação e das condições de circulação e oportunidades.

Os espaços livres públicos e os coletivos privados avaliados foram projetados, concebidos por arquitetos, aprovados nos órgãos competentes, geridos com recursos e interesses atentos à questão e não a espaços da cidade ilegal. Sendo que os espaços projetados têm condições e necessidades de estar dentro dos parâmetros da 
acessibilidade, desde a sua concepção. "O espaço mal concebido acaba concretizando uma segregação não desejada, porém ainda muito presente na sociedade: o que foge do padrão deve ser afastado..." (BAHIA,COHEN e VERAS, 1998).

O espaço livre público é tema importante deste trabalho por tratar-se não somente de espaço de desenvolvimento da cidadania, mas também por ser grande obstáculo para o acesso a espaços construídos, os quais, embora possam ter sido adaptados em função de exigências legais, não podem ser acessados por falta de condições do meio externo a eles, que ainda não são trabalhados de forma global para atender a tais interesses. 


\subsection{Acessibilidade à paisagem}

Nos últimos anos observa-se um notável avanço nas questões que incorporam os direitos das pessoas com deficiência (PCDs).

São consideráveis as conquistas sociais refletidas em legislação, normas e regras de projeto de espaços livres. No entanto, este avanço nem sempre se reflete em espaços de qualidade e de igualdade, seja no conforto, na sociabilidade ou na possibilidade em desfrutar de um mesmo lugar ou paisagem. Muitas são as soluções utilizadas de forma destacada do partido arquitetônico do projeto, gerando espaços de exclusividade no sentido da segregação social e espacial. Os exemplos mais comuns são as rampas pertencentes a percursos secundários aos caminhos principais, os quais têm degraus ou escadarias.

Espaços de qualidade para todos, sem exclusão, podem surgir da utilização dos princípios do desenho universal ${ }^{1}$.

Um projeto para atender aos princípios do desenho universal deve buscar o acolhimento do maior número possível de pessoas, sem distinção. Para atender a tal objetivo, em primeiro lugar é

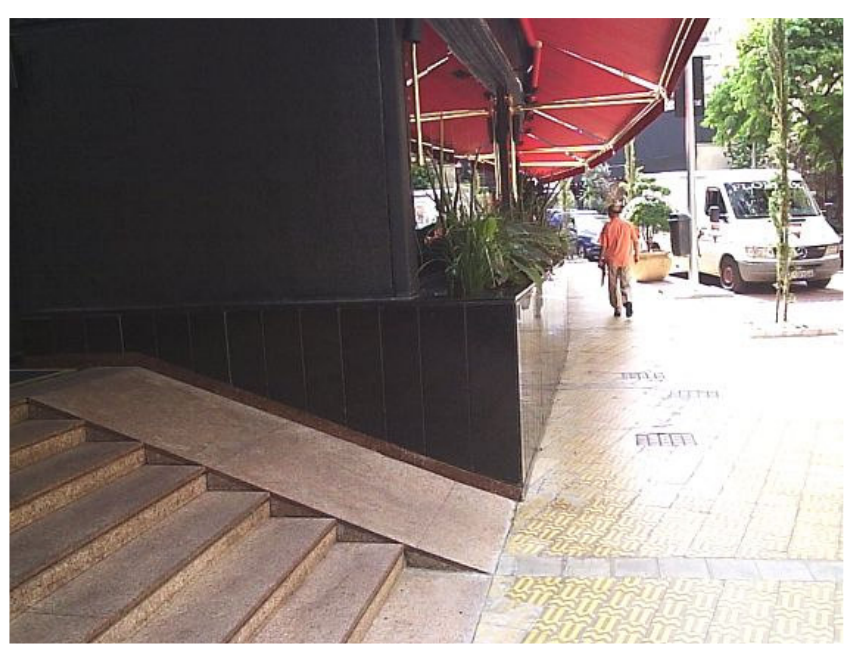

Figura 1 - Rampa inclusa sobre a escada - inserção após a concepção do projeto. O resultado final não atende corretamente ao cadeirante, pois não possui inclinação correta nem corrimãos, tal como está pode ocasionar acidentes, especialmente em idosos, crianças e pessoas com deficiência visual (estabelecimento na Rua Avanhandava).

${ }^{1}$ Para definição e princípios do Desenho Universal, consultar Capítulo 4. 
preciso que este conceito seja incutido nos arquitetos e projetistas de modo geral, para que a concepção de cada projeto parta deste pressuposto, fazendo com que as soluções sejam parte das propostas de projetos e que desta forma não criem espaços de exclusão, mas sim de conforto, de tal forma que todos possam usufruir sem se dar conta das soluções utilizadas para atender aos PCDs.

Não se pode falar em acessibilidade e em desenho universal sem se considerar, também, as questões de execução e manutenção. Para se chegar a um resultado efetivo, todos os aspectos devem ser considerados de forma precisa. Mesmo em projetos concebidos de forma correta, com materiais especificados com propriedade, a execução precisa ser cuidadosa, pois a diferença entre a acessibilidade e a barreira pode estar em $1 \mathrm{~cm}$. Atendendo a estas condições, a manutenção torna-se peça fundamental, para garantir que todo esse esforço continue valendo no uso do espaço.

É importante destacar que todos estes aspetos são importantes e não funcionam se qualquer um destes faltar, no entanto, todo processo começa nas mãos dos projetistas, na concepção.

$\mathrm{Na}$ outra ponta destes trabalhos estão o Poder Público, os clientes e a sociedade de modo geral, que precisam estar alinhados

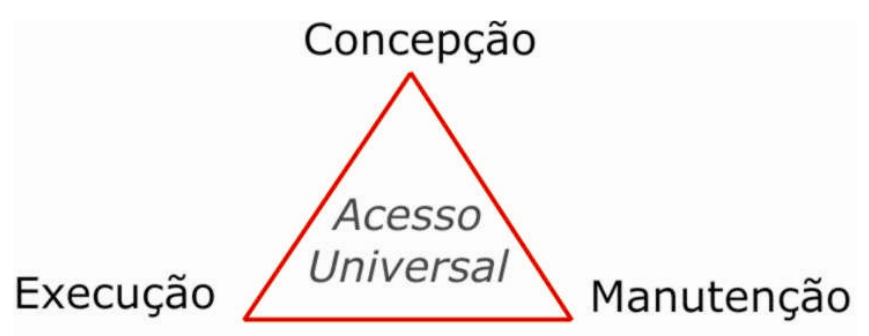

Figura 2 - Sistema para o Acesso Universal 
no mesmo objetivo, de tal forma, que possa haver cobranças e aceitações dentro deste contexto.

A legislação e a Norma atendem aos espaços edificados mais do que aos espaços livres. Como resultado o que se pode observar é o avanço maior nesses locais, chegando a bons projetos com mais freqüência. Entretanto, o espaço livre é a chave para obter-se acessibilidade plena, especialmente por conta das questões logísticas de uso. É pelo espaço livre que se dá acesso a todos os demais espaços físicos e, portanto, merece atenção especial.

Como dito anteriormente, os espaços avaliados, no presente trabalho, estão vinculados a projetos e não à autoconstrução da cidade. Como tal, desde a concepção têm obrigação de considerar as questões que atendam às PCDs, e nos casos apresentados nesta pesquisa, tratam-se de projetos recentes, ainda mais vinculados às reivindicações atuais. Vale destacar desde já, o projeto da Praça da Sé que, nesta dissertação, será apresentado em estudo de caso, como apresentação cuidadosa de propostas a problemas de projetos, encontrados no trato da acessibilidade.

Todas as pessoas possuem restrições para determinadas

atividades. Não se pode esperar, por exemplo, que uma gestante 
divirta-se em uma montanha-russa, nem que um cadeirante pratique arvorismo, no entanto, estas restrições de uso, não devem ser confundidas com restrições de acesso. Situação que será explicitada, posteriormente, no estudo de caso do Playcenter, que demonstra bem esta questão. Desde já se pode, no entanto, deixar claro que esta situação, de restrições de acesso, está ligada às barreiras arquitetônicas e barreiras culturais (ligadas ao preconceito).

Alguns projetos de referência, dentro do estudo de paisagem, como os de Lawrence Hallprin, em que a estética muitas vezes estava baseada em grandes desníveis e escadarias, fazem parte de uma época em que a acessibilidade não era uma pauta consolidada de projeto, no entanto, continuam sendo fonte de inspiração, sem incorporarem, ainda hoje, esta questão.

Por outro lado, novos projetos têm surgido com bons resultados de integração. No caso do Passeio de Manski (1998), em Kouvola, na Finlândia, a rua principal do pequeno povoado foi reformada e tornou-se um passeio público, enquadrado na paisagem finlandesa (GEHL; GEMZOE, 2002). Naquele passeio, existe um canal que acompanha parte do percurso, onde pequenas pontes de pedras cruzam o estreito canal e são elevadas a $2 \mathrm{~cm}$ do piso, para que

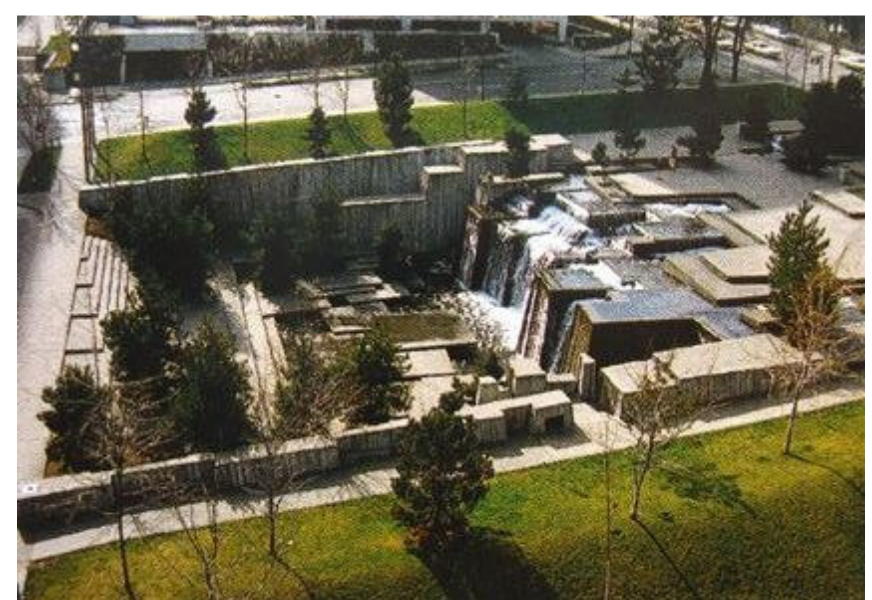

Figura 4 - Auditorium Forecourt Foutain - Lawrence Hallprin, 1970.

Foto: GEHL; GEMZOE, 2002.

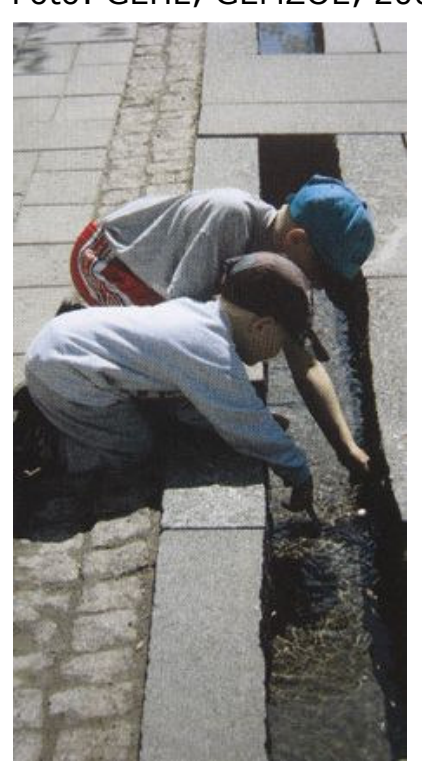

Figura 3 - Passeio de Manski Foto: GEHL; GEMZOE, 2002. 
sejam percebidas por pessoas com deficiência visual. Este detalhe de projeto atende às PCDs e da mesma forma, às demais pessoas, pois todos podem utilizar o mesmo percurso. Como foi pensado desde o início dos trabalhos de projeto, foi incorporado de maneira sutil à paisagem.

Ainda no âmbito internacional, pode ser citado o projeto Cloud Gardens, em Ontário no Canadá (1993). Trata-se de um parque urbano, com espaço restrito e desníveis consideráveis (GEHL; GEMZOE, 2002). O desenho, porém, atende às questões de acesso universal, utilizando-se de rampas e também de escadarias, de tal forma que o acesso se dá como passeios pelo jardim, em percursos que atendem a área como um todo e, em que se possa circular, sem se dar conta das técnicas de acessibilidade que incorporam rampas, margeadas por pequenas muretas, que orientam pessoas com deficiência visual.

No Japão, na cidade de Tsukuba, a Praça Tsukuba Centre Square (1983) foi projetada como praça principal para uma cidade que se constituiu em novo núcleo urbano fora de Tóquio (GEHL; GEMZOE, 2002). O partido de projeto da praça assemelha-se, em partes, aos desníveis utilizados por Hallprin em Auditorium Forecourt
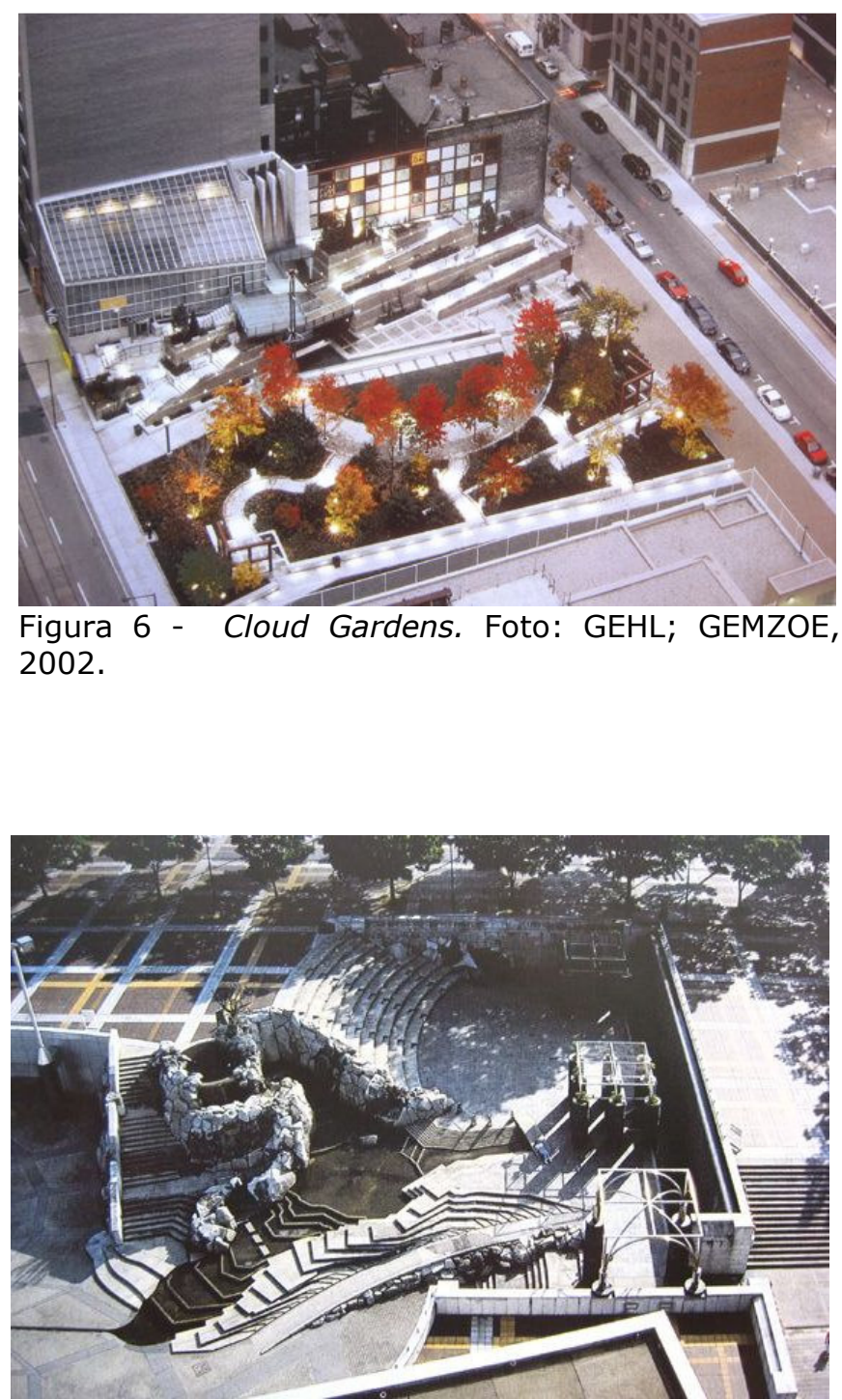

Figura 5 - Tsukuba Centre Square. Foto: GEHL; GEMZOE, 2002. 
Foutain. No projeto japonês, no entanto, existe uma rampa integrada ao conjunto que permite o acesso de cadeirantes.

No Brasil, a cidade de Curitiba apresenta uma solução interessante referente ao sistema de transporte urbano. Os pontos de parada dos ônibus são elevados e todos acessam os ônibus em nível, permitindo um rápido embarque. Para que cadeirantes ou mães com carrinhos de bebês subam para o embarque, existe uma plataforma elevatória mecânica que faz o trabalho.

Nos Estados Unidos, em Portland, Oregon (1982-84), a Pionner Courthouse Square é uma praça que foi projetada com a função de tornar-se um ponto de encontro, com desenho que priorizasse a atividade urbana (GEHL; GEMZOE, 2002). A escadaria, que funciona como atração principal da praça, possui uma rampa integrada ao desenho que permite às pessoas em cadeiras de rodas usarem o mesmo percurso das pessoas que utilizam a escada. Dentro dos parâmetros da Norma Brasileira, essa rampa possuiria alguns problemas, como a falta de corrimãos, por exemplo, que inviabilizaria aquele projeto. Porém, o mais importante a destacar é a solução utilizada que não apenas permitiu o uso de PCDs, mas tornou-se
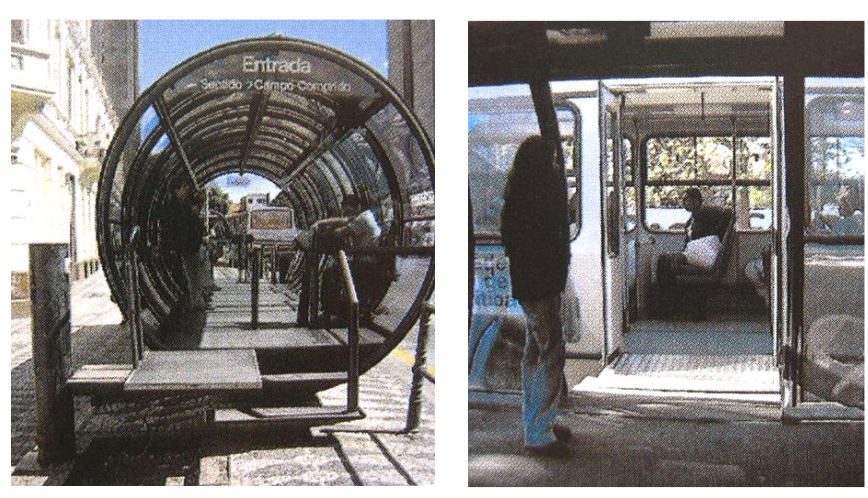

Figura 7 - Ponto de parada em Curitiba. Foto: GEHL; GEMZOE, 2002.

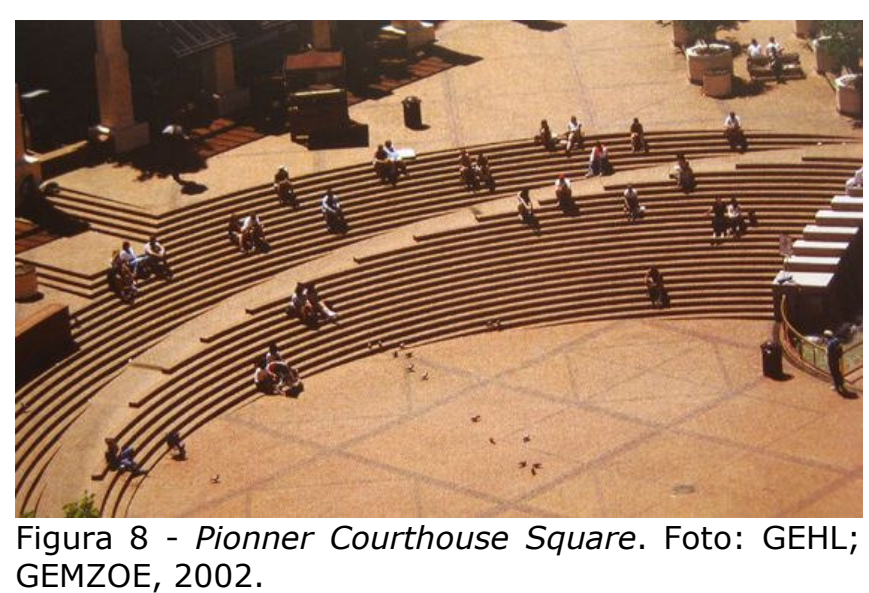


atração para os visitantes e não poderia ter o mesmo efeito se fosse pensada após a concepção do projeto.

Como pode ser visto, existem inúmeras possibilidades de atender às pessoas com deficiência, sem que isso se torne um problema a ser resolvido por imposição de lei. Se a prática projetual incorporar os conceitos do desenho universal, a concepção do desenho do espaço poderá trazer soluções que, não apenas, integrem as PCDs à sociedade, mas também crie espaços agradáveis em que todos possam desfrutar das oportunidades e das sensações de circular em um mesmo lugar.

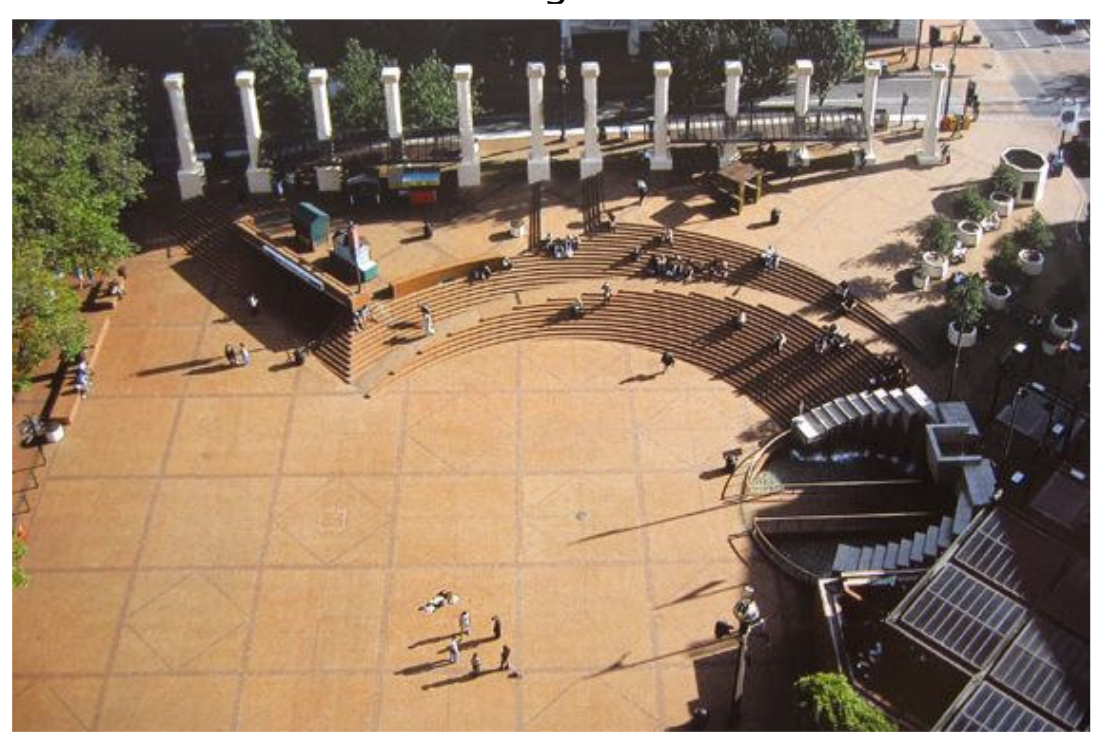

Figura 9 - Pionner Courthouse Square. Foto: GEHL; GEMZOE, 2002. 


\subsection{Conceituação teórica}

No campo nacional, a conceituação teórica sobre questões de acessibilidade foi apresentada por diversos autores. Em destaque, seguem abaixo comentários sobre alguns autores.

Burjato (2004) apresenta estudo de caso sobre o Parque VillaLobos e discorre sobre a necessidade de tornar os parques acessíveis como forma de inclusão ao lazer.

Bahia e Cohen (1998) trazem conceitos de capacidades, direitos das pessoas com deficiência e números, a partir dos quais, se demonstram as competências dos municípios nesta área e qual a importância de suas políticas públicas.

Em Cohen e Duarte (2004), o estudo sobre as condições de circulação pela cidade, para pessoas com dificuldade de locomoção $(P D L)$, baseia-se na psicologia ambiental, para avaliar os sentidos despertados pelas imagens dos lugares, considerando os diversos universos culturais.

Cambiaghi (2004) traz conceitos e exemplos de acessibilidade e inclusão e demonstra técnicas e a importância do ensino do desenho universal nas escolas de graduação em arquitetura. 
Lopes (2005) defende a tese da metodologia de análise e implementação de acessibilidade, nela se encontram técnicas, baseadas em estudos bibliográficos e avaliações pós-ocupação aplicáveis a diversos espaços e temas.

A bibliografia nacional acadêmica que trata da acessibilidade e do acesso universal é bastante recente, acarreta num panorama bastante atual das discussões a respeito do tema, no entanto demonstra também, que há bastante por produzir e amadurecer.

A Norma Brasileira de Acessibilidade - NBR9050/2004 apresenta os parâmetros técnicos para garantir a acessibilidade e norteia a produção legislativa. Nela são encontrados dados sobre alcance, proporções, dimensões e quantificações.

Os Anais do Seminário Acessibilidade no Cotidiano, que foram produzidos em 2004, no Rio de Janeiro, possuem coletânea de artigos apresentados no seminário, voltados para as mais diversas áreas relacionadas à acessibilidade e ao desenho universal, trazendo um panorama atual dos estudos e pesquisas mais recentes.

No campo da bibliografia internacional, existem trabalhos mais consolidados e teorias que orientam as tendências atuais. 
A ADA (American with Disabilities Act) é o mais conhecido estatuto de leis federal norte-americano voltado para os direitos das pessoas com deficiência. Esse estatuto refere-se às condições de trabalho, programas de governo e acesso a serviços e locais públicos.

Na Universidade da Carolina do Norte, onde surgiu o termo universal design (desenho universal), é apontado os princípios relacionados ao tema, além de trazer exemplos e publicações de projetos.

Em Universal Design Handbook há coletânea de artigos e estudos de casos dos mais variados temas, voltados para o desenho universal. Os espaços livres estão bem representados em artigos que orientam o presente trabalho.

Para métodos e conceito de Avaliação Pós Ocupação, as disciplinas AUT-5805 - Avaliação Pós-Ocupação (APO) do Ambiente Construído, de pós-graduação e a AUT - 537 Avaliação Pós-Ocupação, de graduação, contribuíram com esta dissertação de forma teórica e prática. A bibliografia para a disciplina de pós-graduação indicou a Coleção Habitare que, também colaborou para a aplicação de metodologia. 
No entendimento do que vem a ser um espaço livre, Queiroga em Discutindo a Paisagem (2006), contribuiu na conceituação e na distinção entre termos como público, privado e coletivo, dentro do contexto do espaço livre.

Yázigi (2000) traz panorama completo da história do passeio público, a importância deste no contexto da cidade, seja pelo aspecto espacial ou social.

Laurie (1983) apresenta cenário da história do paisagismo e dos conceitos que se modificaram ao longo dos tempos, com exemplos de planejamentos e projetos de paisagem. Nesse trabalho são verificadas evoluções dos conceitos de paisagem, tratando desde a geologia, ecologia, aspectos culturais e populacionais sem entrar no mérito específico da acessibilidade.

Em Novos Espaços Urbanos (GEHL; GEMZOE, 2002) há coletânea de projetos ou reformas de espaços livres recentes, e nele se pode avaliar o quanto as demandas, de acessibilidade, foram incorporadas aos desenhos, embora este não seja o tema da publicação, um olhar atento pode considerar estas questões. 
Contribuições no campo da sensibilidade trouxeram os livros: Um Antropólogo em Marte de Oliver Saks e os Contos Fantásticos do Século XIX, selecionados por Ítalo Calvino. Neste último, o conto Em Terra de Cego de Herbert George Wells (The country of the blind, 1899), em especial, apresentada a história de um vilarejo onde todas as pessoas são cegas e um forasteiro que é vidente (ou seja, que pode ver) passa ser o estranho, que diz coisas absurdas e comete erros constantemente. Saks, autor de Um Antropólogo em Marte, foi um neurologista britânico que escreveu livros sobre os casos de seus pacientes mais dramáticos. É interessante a forma como este autor vê os pacientes e suas deficiências, ele acredita que "(...) a singularidade de cada caso transforma o negativo da deficiência no positivo da compensação".

A bibliografia específica da área de paisagem, em sua maioria, não trata da acessibilidade e da inclusão. Em grande parte, essa bibliografia inclui como temas, mais recentes, os conceitos de espaços voltados para pedestres, aspectos ecológicos, culturais, desenho e projeto. O encontro do tema da paisagem versus desenho universal é possível de se obter, mais facilmente, em estudos internacionais.

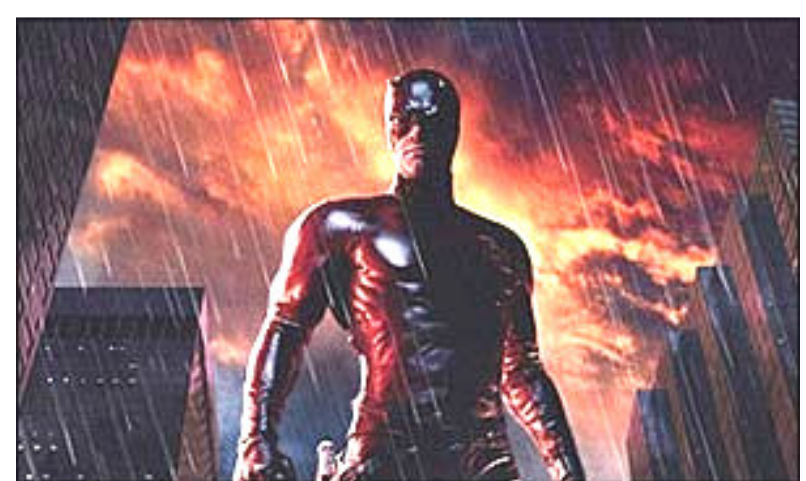

Figura 10 - O Demolidor representa bem o que Sacks pensa sobre a compensação da deficiência.

O Demolidor, Daredevil, foi criado em 1964 por Stan Lee depois da constatação "de que não existia ainda no mercado editorial nenhum herói com deficiência visual. Seguindo seu faro de que heróis parecidos com os próprios leitores, com suas qualidades, defeitos e fraquezas, tinham tudo para virar sucesso, apostou as fichas no garoto Matt Murdock, filho de um pugilista que perde a visão durante um acidente, mas vê aumentar seus outros sentidos, como o tato, o olfato e a audição. Adulto, Matt se transforma num advogado que luta pela justiça nos tribunais. Quando perde, veste seu uniforme vermelho e se transforma num guardião de Nova York, usando seus poderes na luta contra o crime".

Disponivel em:

http://cineweb.oi.com.br/index filme.php?id fil me $=495$. Acesso em 01/2008 


\subsection{Metodologia - aspectos gerais}

O trabalho baseou-se em duas vertentes de pesquisa, a bibliográfica e a empírica.

A primeira constitui de análise sobre os autores teóricos do tema, que introduzem os conceitos de inclusão e análise de elementos arquitetônicos e urbanísticos, sob 0 aspecto da acessibilidade, avaliação pós-ocupação, espaços livres e paisagismo.

A legislação, referente às pessoas com deficiência, foi utilizada nas diferentes esferas - federal, estadual e municipal - para nortear o que há de regras a serem cumpridas e também para avaliar em que medida atende às necessidades reais. A NBR9050/2004 é a maior referência em boa parte dos estudos de acessibilidade e também é importante, como apresentação de parâmetros e panorama de até onde os estudos têm alcançado.

A segunda vertente trata a análise dos espaços in loco, utilizando conceitos da Avaliação Pós Ocupação, especialmente por tratar-se de espaços já consolidados.

As áreas foram delimitadas em cada estudo de caso (calçadas, Praça da Sé e Playcenter). Como avaliação de desempenho, realizou- 
se visitas aos locais, entrevistas, medições, fotografias e análises,

balizadas por conhecimentos técnicos, e comparações com as recomendações da NBR 9050/2004 e legislação.

Foram estabelecidos contatos com os responsáveis pelas áreas estudadas, dirigentes ou gestores públicos, para então iniciar entrevistas com as "pessoas-chaves" para os estudos. A partir desses contatos, dados numéricos e projetos foram levantados, e puderam ser lidos, para depois se realizar medições in loco.

Avaliação, por parte de usuário, só foi possível no Playcenter, onde se pôde percorrer todo o parque em companhia de uma pessoa em cadeira de rodas. A aplicação de questionário e a tabulação dos dados, muito utilizadas na avaliação pós-ocupação, foram descartadas, por questões de viabilidade do estudo. Seriam necessárias muitas visitas e tempo, para que se pudesse obter uma quantidade razoável de entrevistados, que gerasse números estatisticamente confiáveis.

Este trabalho utilizou-se de alguns dos preceitos da avaliação pós-ocupação, porém não se trata da avaliação em si. Os aspectos considerados, como mais importantes, estão relacionados às questões de desenho e uso do espaço livre. 
Das avaliações preliminares resultaram constatações de problemas e soluções, ou mesmo de aplicações corretas de desenhos, em cada um dos estudos que, por sua vez, foram encaminhados aos respectivos dirigentes ou gestores públicos. No caso do Playcenter, este primeiro estudo foi encaminhado e as avaliações prosseguiram, sendo que, a dissertação final, também foi entregue à direção do parque, no sentido de tentar contribuir com a implementação do conceito e de retribuir a atenção dispensada. 


\section{Introdução}

Segundo o Censo 2000 do Instituto Brasileiro de Geografia e Estatística (IBGE), $14,5 \%$ da população brasileira possui algum tipo de deficiência física, mental ou sensorial permanente.

A expectativa de vida da população está aumentando, ou seja, a população está envelhecendo, e as habilidades pessoais vão se tornando cada vez mais debilitadas com o passar do tempo. Segundo - Guia de Acessibilidade em Edificações da Comissão Permanente de Acessibilidade (CPA), estima-se que nos próximos anos o Brasil terá $30 \%$ da população acima de 60 anos. Considerando a quantidade de idosos brasileiros, em função da população, o País ainda não é uma nação de idosos. No entanto, em números absolutos, São Paulo possui, hoje, um terço da população de idosos da Suécia - 4.203 .632 em números absolutos (LOPES, 2005).

No Brasil, a cada ano, 120 mil pessoas adquirem algum tipo de deficiência permanente, em decorrência de acidentes de trânsito,

Proporção da população Brasileira com pelo menos uma deficiênica (CENSO2000)

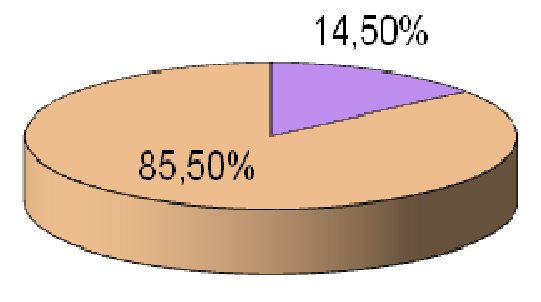

口com deficiência 口sem deficiênica

Figura 11 - Gráfico Pessoas com Deficiências no Brasil 
segundo dados da FUNLAR (Fundação Lar Escola Francisco de Paula -

Rio de Janeiro ${ }^{2}$ ).

Todas as pessoas, em algum momento da vida, terão sua mobilidade reduzida, seja temporária ou permanentemente (gravidez, mãe com criança no colo, carregando pacotes, uma fratura, senilidade...). Sendo assim, onde está o homem padrão? Nossas cidades estão em condições de atender às necessidades desse contingente? A quem elas podem atender?

Os projetos têm considerado, como referência de parâmetros antropométricos e de habilidades, homens com 25 anos de idade em condições perfeitas. No entanto, considerar esta parcela da população, exclui uma grande quantidade de pessoas para a utilização de espaços e equipamentos.

Apesar dos avanços de conscientização, em relação à diversidade humana, muitos projetistas ainda se utilizam de padrões médios para aplicá-los em seus desenhos. 2 BODSTEIN, Regina; RAMOS, Célia Leitão Ramos; HORTALE, Virgínia Alonso. Programa de
Reabilitação Comunitária - Experiência de Inclusão Social da Pessoa Portadora de Deficiência. FUNLAR. Rio de Janeiro, Prefeitura do Rio de Janeiro - 2003. 


\section{Definições}

De forma geral, consegue-se identificar um indivíduo com deficiências, devido a características físicas, sensoriais e mentais visíveis. No entanto, o que o termo significa exatamente é algo um pouco mais difícil de determinar. As definições estão geralmente associadas às barreiras encontradas pelas pessoas e são formuladas em função do tipo de serviço ou regulamento a que devem servir.

Segundo a Norma Brasileira de Acessibilidade, a NBR 9050/2004, deficiência é: "Redução, limitação ou inexistência das condições de percepção das características do ambiente ou de mobilidade e de utilização de edificações, espaço, mobiliário, equipamento urbano e elementos, em caráter temporário ou permanente". A Norma tem a finalidade de estabelecer parâmetros de projeto para "construção, instalação e adaptação de edificações, mobiliário, espaços e equipamentos urbanos às condições de acessibilidade", portanto, utiliza-se em sua definição de deficiência, aspectos que remetem à finalidade descrita, associada às questões referentes ao ambiente. 
Na Lei Federal no. 10.098 de 2000, o termo utilizado é: "pessoa portadora de deficiência ou com mobilidade reduzida"; e é definida como: "a que temporária ou permanentemente tem limitada sua capacidade de relacionar-se com o meio e de utilizá-lo". Esta lei determina a promoção da acessibilidade ao meio, assim como a NBR 9050/2004, porém, ao contrário dessa Norma, não coloca parâmetros técnicos.

A deficiência pode, de fato, segregar pessoas impactando de forma negativa a vida pessoal, social e profissional, no entanto, esse impacto pode ser minimizado ou mesmo dirimido em situações, ambientes e atitudes que levem em consideração as potencialidades do indivíduo e não suas limitações (ORGANIZAÇÃo INTERNACIONAL DO TRABALHO, 2006).

Segundo a Organização Internacional do Trabalho, a deficiência pode ser entendida como:

efeito determinado ambientalmente de um defeito que, em interação com outros fatores e dentro de um específico contexto social [pode trazer] desvantagem em seu/sua vida pessoal, social ou profissional. [Uma limitação] não é o resultado direto de uma limitação ou deficiência existente, mas o resultado de uma interação entre um indivíduo com deficiência, o contexto social e os ambientes imediatos. 
Segundo a NBR 9050/2004 - Acessibilidade a edificações, mobiliário, espaços e equipamentos urbanos -, acessibilidade é: "Possibilidade e condição de alcance, percepção e entendimento para a utilização com segurança e autonomia de edificações, espaço, mobiliário, equipamento urbano e elementos".

Para a Lei Federal no. 10.098 de 2000, a acessibilidade é: "condição de alcance para utilização, com segurança e autonomia, dos espaços, mobiliários e equipamentos urbanos, das edificações, dos transportes e dos sistemas e meios de comunicação, por pessoa portadora de deficiência ou com mobilidade reduzida".

A acessibilidade pode ser entendida como o desenho que segue normas e leis voltadas especificamente para pessoas com deficiência. É o caso, por exemplo, de um livro em Braille. Este pode ser lido, apenas, por pessoas que tenham conhecimento daquela linguagem, embora atenda às pessoas com deficiência visual, nem todas as pessoas podem lê-lo.

Outro conceito relacionado à acessibilidade é a adaptação. A adaptação refere-se às correções realizadas posteriormente, tornando um lugar, ou algo, utilizável por pessoas com deficiência.

Geralmente, as soluções encontradas se apresentam de maneira 
descolada do projeto de forma integral, demonstrando que a prática da inclusão, de pessoas com deficiência, ao espaço projetado não fez parte da concepção inicial do projeto, mas sim da atitude tardia de correção.

Sendo assim, o conceito mais atual e abrangente é o Desenho Universal $^{3}$ (Universal Design). O qual procura atender a todas as pessoas, independentemente da idade, habilidade física, habilidades sensoriais ou cognitivas. O desenho universal pode não atender, absolutamente, todas as pessoas, mas procura acolher o maior número possível de pessoas e, por isso, deve fazer parte da prática projetual. Com a utilização deste conceito, as habilidades são enfatizadas em detrimento das desabilidades e o conforto do uso se estende a qualquer pessoa, com ou sem deficiência, priorizando soluções simples e integradas.

${ }^{3}$ Para Desenho Universal, consultar capítulo 4. 


\section{Uma questão cultural}

A acessibilidade pode ser considerada sobre dois aspetos diferentes: o físico e o cultural. Considerando os fatores do meio físico, os problemas são conhecidos e relativamente fáceis de detectar, como os degraus, os balcões altos, etc. As condicionantes culturais são mais difíceis de serem percebidas, porém fundamentais no processo de inclusão. As pessoas que não possuem deficiência, ou não lidam com a questão, não costumam perceber os entraves à acessibilidade e acabam contribuindo para agravar o problema, seja criando os entraves físicos ou com reações de preconceito ou piedade no cotidiano.

A deficiência é um tema tratado desde a existência do homem, pois faz parte da diversidade humana.

$\mathrm{Na}$ Antigüidade, as pessoas que possuíam algum tipo de deficiência eram vistas como castigadas pelos deuses ou demônios. Após essa fase, a caridade e o assistencialismo passaram a ser praticados de forma piedosa e solidária e muitas vezes as pessoas 
com deficiência ficavam confinadas em instituições ou guetos, sendo muito ligadas a atitudes de cunho religioso ${ }^{4}$.

Em 1948, a Organização das Nações Unidas (ONU) lançou a Declaração dos Direitos Humanos. Neste documento, fica determinado que todas as pessoas possuem direitos iguais perante a lei, direito ao trabalho, à seguridade social, à igualdade e à liberdade. Nesse contexto, estão as questões de inclusão social da pessoa com deficiência, ainda em fase preliminar, na época.

Como conseqüência das Grandes Guerras, dos conflitos resultantes da Guerra Fria e da Guerra do Vietnã, criou-se uma multidão de pessoas mutiladas, que precisariam retomar suas vidas e exigiam participação social, após terem servido bravamente à pátria (especialmente no caso norte-americano), as questões de direito legal à acessibilidade e de cidadania fortalecem-se ${ }^{5}$.

Segundo Bahia, Cohen e Veras (1998), em 1963, foi criada a Comissão para o Desenho Livre de Barreiras em Washington - EUA, essa constituiu corrente ideológica para a produção de objetos,

4,5 GIL, Marta. Deficiência: uma forma de viver o mundo. Texto extraído do livro Município Acessível ao Cidadão - Unidade de Políticas Públicas - UPP. 
edifícios e espaços urbanos, a qual determinava que os problemas de acessibilidade estavam vinculados às barreiras encontradas no meio, e não exclusivamente à pessoa com deficiência, propiciando a segregação. De acordo com os mesmos autores, este conceito considerava não apenas remoção das barreiras, mas maneiras de não as criar.

No Brasil, em 1969 a Emenda Constitucional no 1 inicia a questão do reconhecimento dos direitos da pessoa com deficiência, considerando os casos de "invalidez" para a aposentadoria e assistência aos "excepcionais".

Em 1975, surgiu a Declaração dos Diretos das Pessoas Deficientes elaborada pela ONU, que garante direitos sociais, políticos, legais e de cidadania.

$\mathrm{Na}$ evolução dos conceitos de inclusão, nasce em 1989, na Universidade da Carolina do Norte - EUA - o Centro para o Desenho Universal (The Center for Universal Design - North Carolina State University - NCSU), fundando por Ronald L. Mace. O instituto desenvolve pesquisa, informação e oferece assistência técnica em acessibilidade e desenho universal para residências, construções, espaços livres, ambientes urbanos e produtos. 
Segundo Mace, "O desenho Universal é o desenho de produtos e ambientes utilizáveis por todas as pessoas, com a maior possibilidade possível, sem a necessidade de adaptações ou projetos específicos". O objetivo do desenho universal é simplificar a vida de todos através de produtos, informações e ambientes construídos mais adequados ao uso, do maior número de pessoas, sem grandes ou qualquer custo ${ }^{6}$.

Atualmente, o conceito de caridade e assistencialismo ainda não foi totalmente abolido, embora exista o discurso da integração e direitos iguais, necessários para garantir a inclusão na sociedade. Essa situação é reforçada pela falta de convivência com pessoas que possuem deficiência. A insuficiência de condições de acessibilidade, nos espaços livres públicos, faz com que, parte destas pessoas, fique confinada em suas residências ou em clínicas. $O$ ambiente construído é mais fácil de ser adaptado, porém, sem o meio urbano adaptado, não se tem acessibilidade, e sem esta, não há aceitação e integração. 


\section{A deficiência em números.}

A Organização Mundial da Saúde (OMS) estima que 10\% da população dos países em desenvolvimento, que não estejam em guerra, tenham algum tipo de deficiência.

No Censo de 2000, o IBGE aponta para um percentual de $14,5 \%$ da população, o equivalente a 24,5 milhões de brasileiros com pelo menos uma deficiência. Deste total, $48,1 \%$ é referente às deficiências visuais, 22,9\% deficiência motora, 16,7\% deficiência auditiva, 8,3\% deficiência mental e 4,1\% deficiência física.

Segundo estudo realizado pela Associação Fluminense de Reabilitação, publicado pela CORDE - Coordenadoria Nacional para Integração da Pessoa Portadora de Deficiência, a deficiência está mais presente em populações socialmente desfavorecidas e não se pode dizer ao certo se a deficiência é causa ou conseqüência de tal condição.

Ao serem avaliados, os dados do CENSO 2000, observa-se que a Região Nordeste possui o maior porcentual, com $16,7 \%$ da
Proporção da população Brasileira com pelo menos uma deficiênica (CENSO2000)

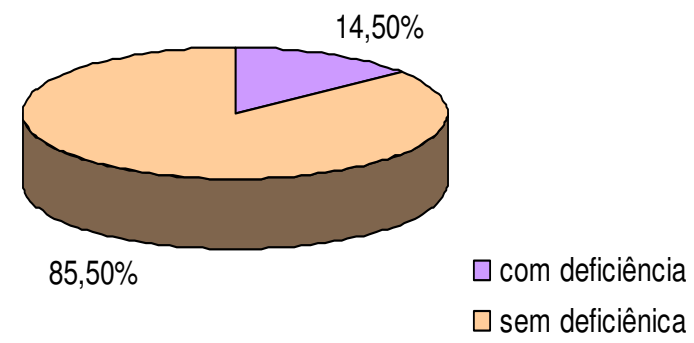

Figura 12 - Gráfico Pessoas com Deficiência no Brasil

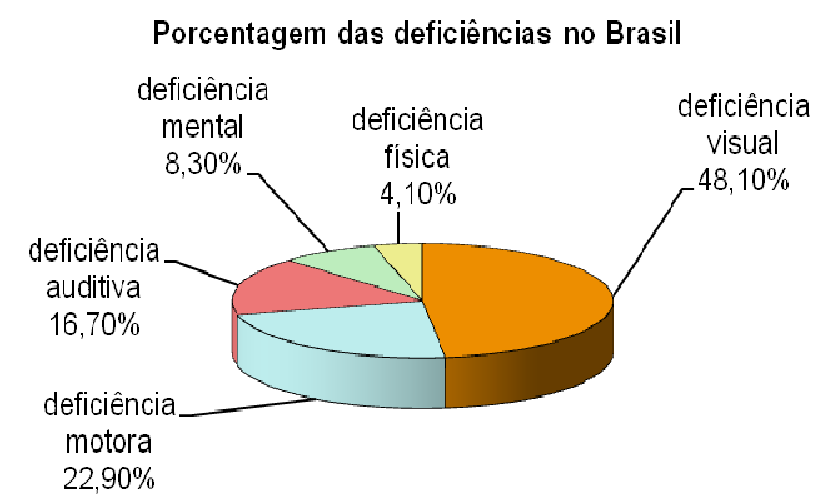

Figura 13 - Gráfico tipos de Deficiências no Brasil 
população com algum tipo de deficiência, enquanto que a Região Sudeste possui $12,9 \%$.

Essa disparidade demonstra que as questões, voltadas à pobreza, aumentam em grande proporção as deficiências, especialmente, se considerados os problemas de nutrição e atendimento à saúde.

A Região Nordeste do País possui os maiores índices de pobreza e fome, enquanto que nos estados ricos, como São Paulo e Paraná, embora também possuam problemas desta natureza, são de intensidade muito inferior, quando considerada a média nacional, por isso, a menor taxa de deficiência.

\begin{tabular}{|l|r|r|}
\hline $\begin{array}{l}\text { Grandes } \\
\text { Regiões }\end{array}$ & $\begin{array}{c}\text { Proporção da população } \\
\text { com pelo menos uma das } \\
\text { deficiências investigadas (\%) }\end{array}$ & $\begin{array}{c}\text { Distribuição da população } \\
\text { com pelo menos uma das } \\
\text { deficiências investigada } \\
(\%)\end{array}$ \\
\hline Brasil & 14,5 & 100,0 \\
\hline Norte & 16,1 & 8,5 \\
\hline Nordeste & 16,7 & 32,5 \\
\hline Sudeste & 12,9 & 38,1 \\
\hline Sul & 14,1 & 14,4 \\
\hline $\begin{array}{l}\text { Centro- } \\
\text { Oeste }\end{array}$ & 13,7 & 6,5 \\
\hline
\end{tabular}

Fonte: http://www.mj.gov.br/sedh/ct/corde/dpdh/sicorde/censo2000.asp

ata: a Região Sudeste possui maior número absoluto de pessoas com deficiências, apesar da menor porcentagem, por ser mais populosa. 
O grau de instrução das pessoas com deficiência também é indicador que demonstra a exclusão social. Das pessoas sem instrução alguma, ou com até 3 anos de estudo, 32,9\% possuem deficiência, segundo o IBGE. Aliada à questão da renda baixa dessa parcela da população, estão às dificuldades de circular pelos espaços livres públicos, de chegar às escolas e de encontrar escolas acessíveis. Desta forma, cria-se um ciclo vicioso, em que parcela das pessoas com deficiência não estUda porque a renda não permite criar alternativa, e não têm renda porque não têm condições de se instruírem. Quando consideradas pessoas com mais de 11 anos de estudo, as que possuem deficiência são apenas $10 \%$ do total.

Os dados relativos à porcentagem de pessoas com deficiência aumentam em função da faixa etária considerada. Segundo o CENSO 2000, até 14 anos de idade, a taxa de deficiência é de 4,3\%, para pessoas com mais de 65 anos a taxa passa a ser de $54 \%$, e para pessoas com 80 anos ou mais a taxa é de $70 \%$. 


\section{Causas das deficiências}

No Brasil, as causas das deficiências são diversas e comuns aos países ricos e aos países em desenvolvimento, segundo estudo do CEPAM (Fundação Prefeito Faria Lima - Centro de Estudos e Pesquisas de Administração Municipal).

De acordo com a Fundação, em comum com os países em desenvolvimento estão: a desnutrição, o mau atendimento ao parto, a falta ou a ineficácia do atendimento à saúde.

Dentre as causas de deficiências comuns aos países desenvolvidos, como alerta o CEPAM, estão os acidentes de trânsito, acidentes de trabalho, doenças ligadas ao estresse, enfermidades cardiovasculares, cerebrovasculares, diabetes e à poluição.

Outro fator é a violência urbana que faz vítimas, especialmente, nas grandes capitais brasileiras e essas são noticiadas freqüentemente nos jornais. A violência doméstica, praticada mais comumente contra mulheres e crianças é outro gerador de deficiências. Somado a estes fatores estão os problemas congênitos, inerentes à espécie humana. 
Neste panorama é importante destacar, que políticas públicas têm papel fundamental na prevenção à deficiência. Cuidados com a saúde pré-natal e pós-natal, atendimento à nutrição adequada, campanhas de vacinação, normas, programas e fiscalização para evitar acidentes de trabalho e de trânsito, são algumas das políticas públicas que trazem ganhos na prevenção à deficiência (PEREIRA, 2007). Como já foi apresentado anteriormente, estados brasileiros que possuem maior riqueza, e conseqüentemente, maior condição de atendimento à população, possuem menores índices de deficiências.

Segundo Pereira (2007), dados da OMS - Organização Mundial da Saúde - revelam que $70 \%$ das deficiências poderiam ser evitadas com medidas de prevenção. De acordo com a autora, considerandose questões financeiras, a prevenção tem impacto muito menor no orçamento, se comparado com os gastos em reabilitação, que requerem tecnologias mais avançadas. Se a prevenção custa menos que os tratamentos posteriores, então a falta de planejamento e atenção, aliados aos entraves burocráticos, dificultam a evolução das possibilidades de redução das taxas de deficiências no Brasil. 


\section{Legislação}

Segundo Lopes (2005), a legislação relativa às pessoas com deficiência começou no Brasil, em grande parte, em função de ações internacionais. Mesmo havendo legislação nacional voltada nesse sentido desde 1975, apenas em 1981, com o Ano Internacional das Pessoas Deficientes, instituído pela ONU, que ações relevantes começaram a ser desenvolvidas no País.

No período correspondente a 1985 a 1990, a autora destaca duas Leis Federais importantes, a Lei 7.405 de 1985 e a Lei 7.853 de 1989. A primeira dispõe sobre a obrigatoriedade da utilização do Símbolo Internacional de Acessibilidade em ambientes e locais acessíveis, ou que prestem serviços às pessoas com deficiência. A segunda trata das ações de apoio e integração social à pessoa com deficiência e cria a CORDE - Coordenadoria Nacional para Integração da Pessoa Portadora de Deficiência. A CORDE é o órgão federal, ligado à Secretaria Especial dos Direitos Humanos, responsável pela gestão e implementação de políticas públicas referentes às pessoas com deficiências, balizada também pelo Decreto no. 3.298 de 1999, que regulamenta a Lei 7.853 e dispõe sobre "a Política Nacional para 
a Integração da Pessoa Portadora de Deficiência, [e] consolida as normas de proteção".

A legislação subseqüente a esse período, de acordo com Lopes, assistiu à pessoa com deficiência especialmente nas questões dos benefícios, pensões, isenções e assistência social de modo geral, fatores muito importantes para a inclusão. Porém ainda bastante ligadas às demandas assistencialistas, sem incorporar ações com a ideologia de direito às oportunidades e inclusão social.

$\mathrm{Na}$ década de 90, surgiram leis e decretos, nas diferentes esferas nacionais contraditórias entre si, o que tornou a aplicação um tanto difícil, pois criou possibilidades de não implantar as determinações de uma lei em função de outras (LOPES, 2005).

Em 2000, a Lei Federal 10.098 estabeleceu normas e critérios, baseados na NBR 9050 de 1994, para promover acessibilidade em espaços públicos, transporte e na reforma e construção de edificações.

Em 2004, foi apresentada nova versão da NBR9050, com novos parâmetros, e também assinado o Decreto no. 5.296 que regulamenta as Leis $\mathrm{n}^{\circ}$. 10.048 e 10.098 de 2000 , citando em seu 
texto as normas da ABNT - Associação Brasileira de Normas

Técnicas, voltadas à acessibilidade. O Decreto trata das prioridades da pessoa com deficiência em suas atividades, e constitui critérios para fomentar a acessibilidade. Um aspecto a ser observado é que os parâmetros adotados pelo Decreto são conflitantes com a Norma e legislações anteriores, regulamentando quantidades e prazos divergentes sem, no entanto, impor sanções, desta forma, apenas o Ministério Público aplica as penas, dependendo do foco dos trabalhos em andamento no Ministério, ou de denúncias por parte dos cidadãos que se sintam lesados. Vale lembrar que o Decreto tem "força" maior que as leis, às quais regulamenta, e às demais leis de outras esferas de poder.

Um exemplo de contradição entre a Norma da ABNT e o Decreto é que a NBR9050/2004 estabelece que os sanitários acessíveis devem estar "preferencialmente próximos ou integrados às demais instalações sanitárias", já o Decreto 5.296/2004 determina que esses devem possuir "entrada independente dos sanitários coletivos, obedecendo às normas técnicas de acessibilidade da ABNT". 
Em São Paulo, a legislação estadual e municipal dá enfoque às questões de cunho prático, não se detendo especificamente a terminologias e definições. O município de São Paulo seguiu as tendências internacionais, compassando o surgimento da legislação municipal com os marcos internacionais.

Dentre as estaduais em destaque existe a Lei 3.710 de 1983, uma das primeiras leis estaduais com o tema, que estabelece as condições de acesso aos edifícios públicos, por pessoas com deficiências. O Decreto 33.824 de 1991 também versa sobre a adequação dos edifícios do estado à acessibilidade.

No Município, a Lei 9.199 de 1980 obriga os edifícios de uso público a garantirem acessibilidade da rua até a entrada da edificação. Foi um início, ainda que incipiente, para que o próprio Poder Público desse o exemplo.

A Lei 11.228 de 1992 regula o Código de Obras e Edificações do Município de São Paulo (COE). Esta lei em seu Decreto no. 33.329 de 1992 vincula as questões de acessibilidade à NBR 9050. No entanto, algumas colocações do COE diferem dos parâmetros apresentados pela Norma, como dimensões de sanitários e quantidade de vagas em estacionamento e, segundo Lopes (2005), requerem revisões. 
Já a Instrução Normativa / SAR / 01 / 2000 consiste em uma orientação legal para a compreensão e aplicação do conjunto de leis, decretos e normas regulamentares, que tratam da acessibilidade, definindo penalidades, que não existem em algumas dessas legislações.

As conquistas sociais brasileiras nasceram de movimentos reivindicatórios. A acessibilidade não é diferente. Porém, esses movimentos surgiram a partir de grupos sociais esclarecidos, e com poder de mobilização político e econômico. Desta forma, pode-se perceber que, os parâmetros e a literatura que tratam da acessibilidade e de direitos das pessoas com deficiência, estão voltados, especialmente, para os espaços construídos, em particular, aos locais freqüentados por pessoas de classes mais favorecidas, como shopping centers, teatros, restaurantes, etc..

$\mathrm{Na}$ prática, embora a legislação refira-se aos direitos de acessibilidade em transporte público, espaço livre público e coletivo, pouco de vê em projetos e em atendimento a essa legislação. Mesmo a Norma Brasileira de Acessibilidade, na sua última versão, a NBR $9050 / 2004$, pouco se detém no trato desta questão, visto que é complexa. Porém, o acesso universal ao meio externo, o espaço livre 
público, é mais importante do que a acessibilidade em edifícios, pois - acesso universal só pode ser alcançado de forma completa, se atingir a todos. Se o espaço externo, que é onde se dá a ligação de todos os edifícios, e onde se desenvolve a cidadania, não for utilizável por todos, de forma plena, os demais espaços, mesmo que acessíveis, passam a ser utilizados somente por uma específica classe social, a qual pode utilizar automóvel. 


\section{A questão sobre a inclusão social de pessoas com}

\section{deficiência .}

O acesso universal é um direito e uma questão cultural. A falta dele é fruto não de uma incapacidade do indivíduo, e sim de um meio deficiente, que limita e segrega pessoas com diferentes condições físicas, mentais e sensoriais.

Segundo Duarte e Cohen (2004), as pessoas com algum tipo de deficiência "Ao serem impedidas de experienciar os espaços construídos como a maioria das pessoas, as diferenças concretas das PDLs (pessoas com dificuldade de locomoção) ficam ainda mais evidentes e geram o peso psicológico da realidade de pertencer a uma minoria, contribuindo para o processo de segregação psicossocial e de exclusão espacial".

Segundo as autoras, quando uma pessoa com deficiência depara-se com uma barreira física, ou uma barreira gerada por atitudes de discriminação, é que ela se sente "diferente", desenvolvendo sentimentos de inferioridade. Desta forma, o espaço urbano exclui as pessoas com deficiência e estas rejeitam o espaço urbano por tais constrangimentos, se tornando um "ciclo vicioso". "A 
exclusão espacial e a exclusão social passam, então, a significar praticamente a mesma coisa" (DUARTE; COHEN, 2004).

Os espaços públicos deveriam ser exemplos de locais acessíveis, pois, um espaço chamado de público, por definição, não deve segregar pessoas, independentemente de suas condições, o que ainda não ocorre. Como exemplo, podemos citar:

- As condições das calçadas, inviáveis para circulação dos pedestres;

- Praças e parques inacessíveis e;

- O transporte público.

Os espaços de uso coletivo, mesmo que privados, também devem ser acessíveis e atender aos parâmetros da NBR 9050/2004, de acordo com o Decreto no. 5.296 de 2004.

O espaço livre público é o lugar de desenvolvimento da cidadania, e também um grande obstáculo para o acesso a ambientes construídos que, embora possam ter sido adaptados, em função de exigências legais, não podem ser acessados por falta de condições do meio externo a eles, que ainda não são trabalhados de forma global para atender a tais interesses. 
A presente dissertação pretende discutir a acessibilidade como forma de inclusão social e como parte da concepção de projetos. Os espaços avaliados estão vinculados a projetos e não a espaços da cidade ilegal, pois os espaços projetados têm condições e necessidade de estar dentro dos parâmetros da acessibilidade, desde a sua concepção.

Neste contexto, o Acesso Universal, deve contemplar a toda e qualquer pessoa, independentemente das características físicas, sensoriais, mentais e sociais, visto que a cidadania e a responsabilidade social fazem parte desta discussão.

A equiparação de oportunidades por meio da garantia de acesso constitui o caminho adequado para minimizar ou suprimir as barreiras sociais. Quando oportunidades como o acesso aos aspectos fundamentais da vida são concedidas a uma parcela da população e negadas às pessoas portadoras de deficiência, criam-se obstáculos à participação plena deste grupo na sociedade. Os efeitos desta atitude são a marginalização e a segregação sociais (BAHIA,COHEN e VERAS, 1998).

A questão da circulação e da orientação da pessoa com deficiência é o caso mais extremo a ser considerado em análise de condições de acessibilidade no espaço livre público. No entanto, 
sendo satisfeitas as necessidades dessa parcela da população, todos estarão usufruindo de melhor qualidade de vida.

O território é espaço de possibilidades, expressões concretas de como é possível permanecer vivo, apesar das dificuldades. Nele também é possível conhecer o sentido atribuído às coisas, à vida, compreender e empreender a produção de valores e trocas sociais. É ainda um dos lugares de produção de saberes sobre o mundo, sobre a deficiência, sobre os problemas e sobre soluções encontradas para superá-los (OLIVER, 2002). 


\section{Desenho Universal}

O termo original, Universal Design, foi criado nos Estados Unidos por Ronald L. Mace, fundador do The Center for Universal Design, da Universidade da Carolina do Norte em Raleigh.

Segundo Mace, "O desenho Universal é o desenho de produtos e ambientes utilizáveis por todas as pessoas, com a maior gama possível, sem a necessidade de adaptações ou projetos específicos". O objetivo do desenho universal é simplificar a vida de todos através de produtos, informações e ambientes construídos mais adequados ao uso do maior número de pessoas possível sem grandes ou qualquer custo $^{7}$. 
De acordo com o Center for the Universal Design, o desenho universal deve atender a 7 princípios ${ }^{8}$ :

1. Igualdade de Uso - deve ser utilizável por todos. De forma idêntica, ou pelo menos equivalente, evitando situações estigmatizadas;

2. Flexibilidade de Uso - o desenho deve acomodar a maior gama de habilidades e preferências de uso. Para isso é importante permitir diferentes formas de utilização, facilitar o emprego por destros e canhotos, promover a precisão e se adaptar ao ritmo de cada pessoa;

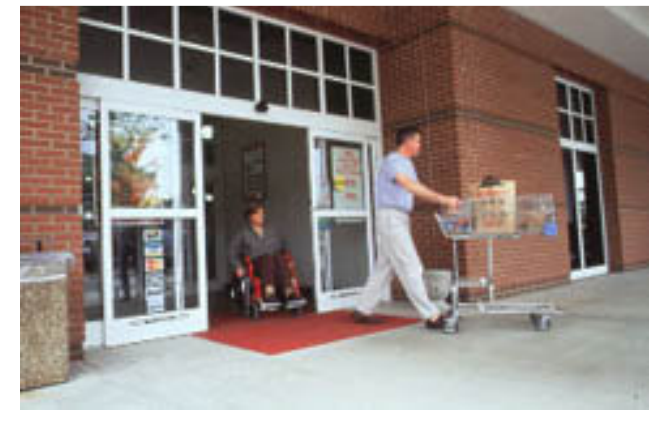

Figura 14 - Princípio 1 - Igualdade de Uso

Foto: http://www.design.ncsu.edu

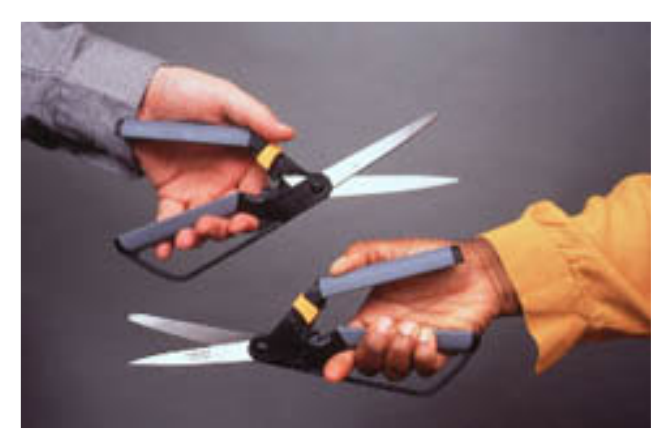

Figura 15 - Princípio 2 - Flexibilidade de Uso

Foto: http://www.design.ncsu.edu 
3. Simplicidade e Intuição - o desenho deve ser de fácil compreensão, não necessitando de conhecimento prévio, experiência ou grande concentração. Para atender a este princípio, devem-se eliminar complexidades desnecessárias, atender às expectativas de uso intuitivo e promover diálogo durante as operações, que permita o acompanhamento da tarefa;

4. Informação Perceptiva - as informações necessárias ao uso não podem depender das condições do ambiente do entorno, nem das habilidades sensoriais do usuário. Diversos modos de apresentação de informação, de maneira redundante, poderão permitir atingir este objetivo. O contraste entre a informação essencial e às demais, com máxima legibilidade, em diversos elementos de descrição, proporcionam maior possibilidade de compreensão;

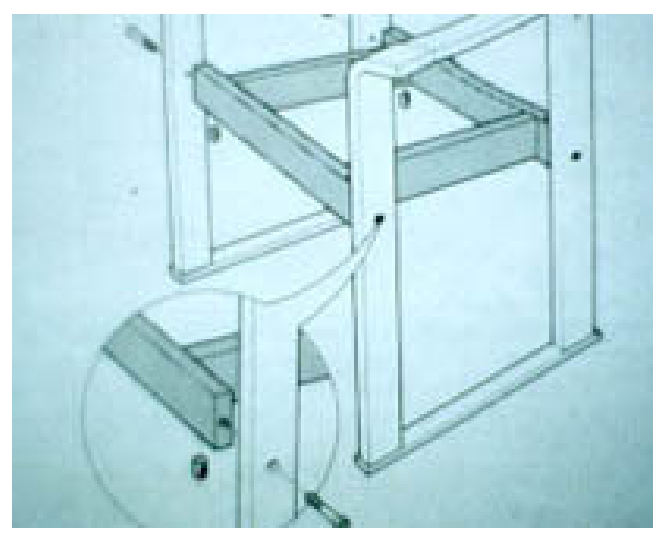

Figura 16 - Princípio 3 - Simplicidade e Intuição

Foto: http://www.design.ncsu.edu

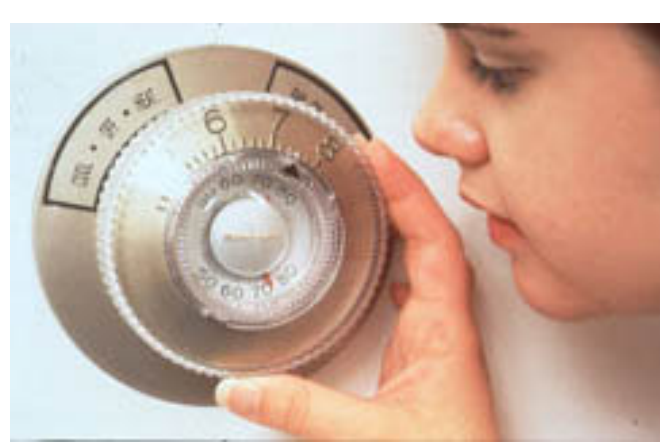

Figura 17 - Princípio 4 - Informação Perceptiva. Nesta imagem equipamento conjuga dados visuais ampliados, informação tátil e sonora do movimento realizado.

Foto: http://www.design.ncsu.edu 
5. Tolerância ao Erro - o desenho minimiza a possibilidade de erros e emite alerta para confirmar ações de importância relevante. Em caso de ações acidentais, o erro pode ser evitado.

6. Baixo Esforço Fí́sico - o desenho permite o uso eficiente e confortável com mínimo esforço, evitando a fadiga. Para isso é necessário que o usuário mantenha postura neutra durante a operação, que ações repetitivas sejam evitadas e que esforços de sustentação física sejam diminuídos.

7. Dimensão e Espaço que Permitam Aproximação e Uso Tamanho e espaço apropriados que permitam aproximação e manipulação de forma a manter o corpo seguro, a postura correta e a mobilidade.

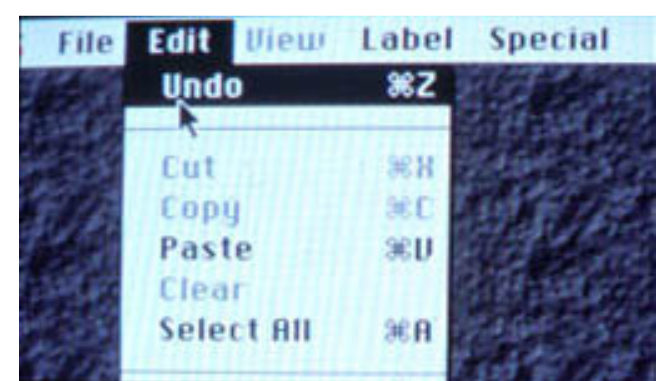

Figura 18 - Princípio 5 - Tolerância ao Erro

Foto: http://www.design.ncsu.edu

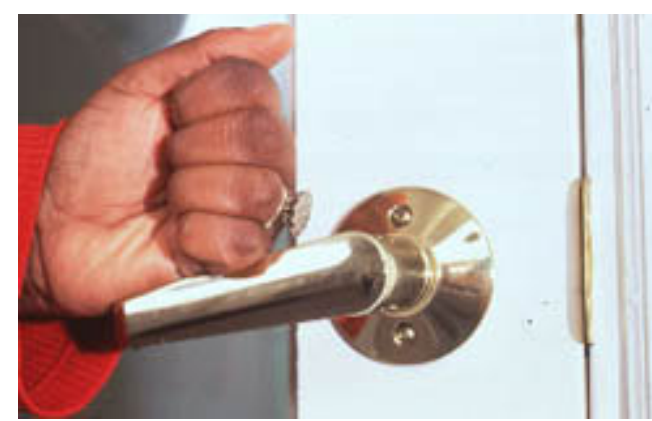

Figura 19 - Princípio 6 - Baixo esforço físico

Foto: http://www.design.ncsu.edu

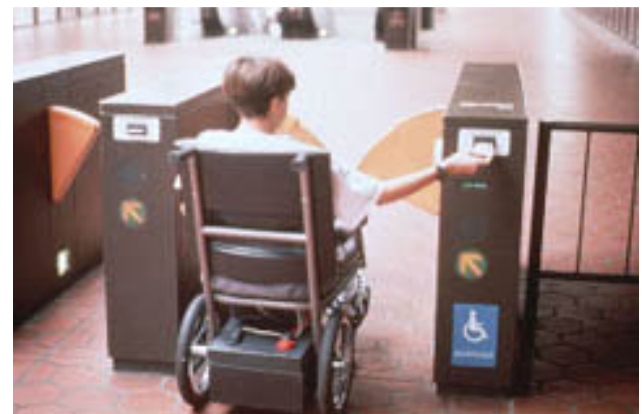

Figura 20 - Princípio 7 - Dimensão e

Espaço para Aproximação e Uso

Foto: http://www.design.ncsu.edu 
O desenho universal procura acolher todas as pessoas, independentemente da idade, habilidade física, sensoriais ou cognitivas. Muito embora a prática desse conceito não atinja a todas as pessoas, a maior parte possível delas é atendida. Assim, as habilidades são enfatizadas em detrimento das desabilidades e o conforto se estende a qualquer pessoa, priorizando soluções simples em lugar de múltiplas alternativas.

Atender a todas as pessoas de forma igualitária, no sentido total do conceito, torna-se algo utópico dentro da diversidade de condições físicas, culturais e cognitivas humanas. O mais importante, dentro deste contexto, é fazer com a sociedade o assimile para que a concepção de projetos passe a fazer parte do universo comum e as soluções possam surgir, não de regras ou normas, mas do bom senso e da criatividade.

Atendendo aos princípios do desenho universal, tem-se o conforto de saber que se está de acordo com as normas e legislações vigentes, as quais tratam da acessibilidade e direitos das PCDs, atraindo também, ganhos de imagem socialmente correta.

Os benefícios econômicos são ampliados na medida em que se aumenta a possibilidade de independência da pessoa com deficiência, 
dando-Ihe autonomia, o quê significa também, desocupar um indivíduo economicamente ativo, o qual não mais precisará dedicar seus cuidados integrais à PCD.

A criação de produtos e espaços de uso intuitivo poderá representar ganho financeiro, por propiciar sua utilização, independentemente da língua ou cultura. No caso dos produtos, essa possibilidade aumentará a quantidade de consumidores, e assim o preço unitário poderá diminuir.

Socialmente, o desenho universal proporciona a inclusão de pessoas, de forma democrática e cidadã. A sociedade cresce com a participação de todos e com a convivência com a diversidade.

No desenho do espaço livre, a aplicação do desenho universal pode gerar ganhos em qualidade de vida, através de acessos bem dimensionados, caminhos intuitivos, etc., trazendo soluções que não são específicas para as pessoas com deficiência, mas que atendam também a elas, da mesma forma. 


\section{Estudo de caso - Praça da Sé}

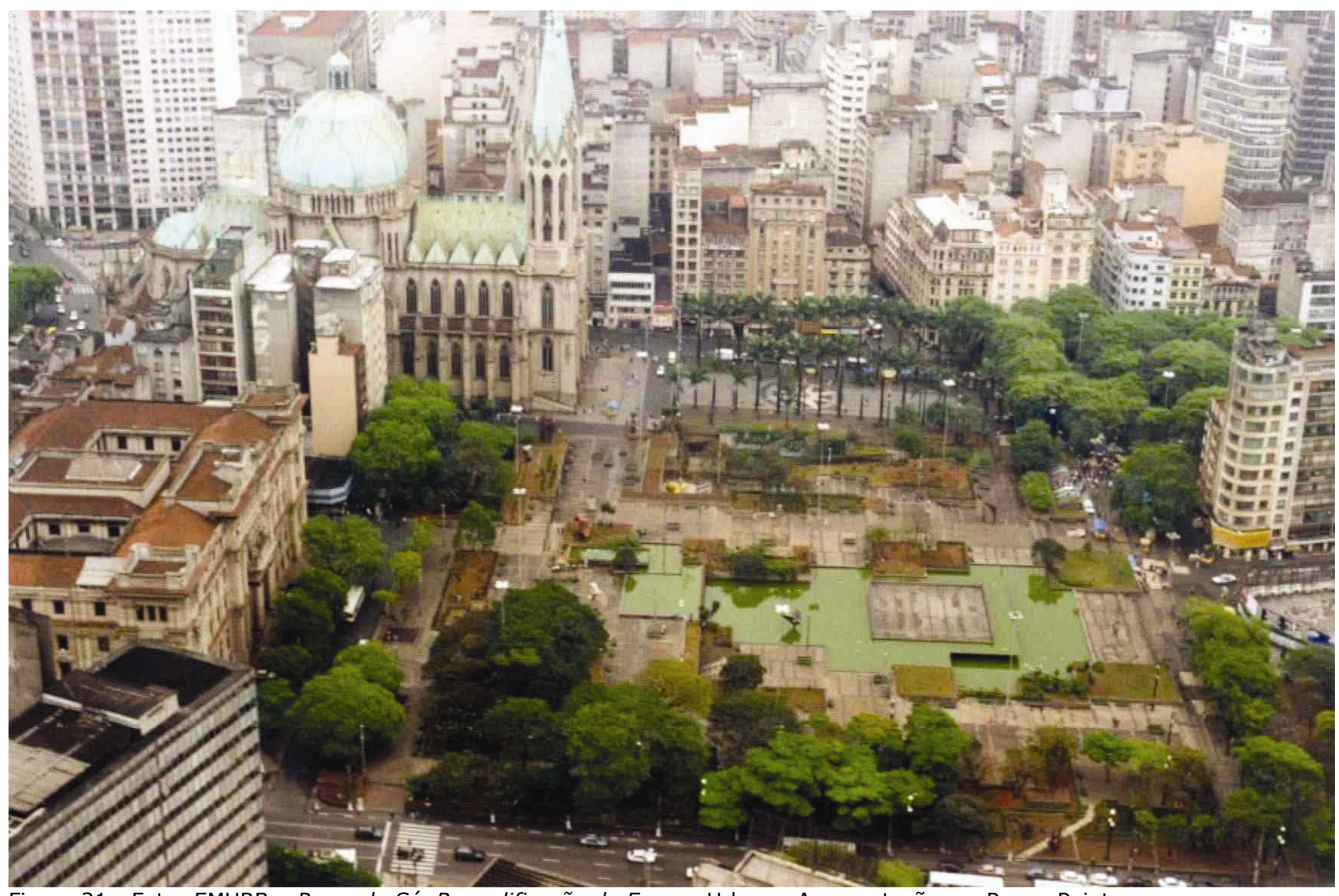

Figura 21 - Foto: EMURB - Praça da Sé. Requalificação do Espaço Urbano. Apresentação em Power Point. 


\section{Apresentação - Justificativa da escolha}

A Praça da Sé faz parte de um conjunto de praças, construídas na década de 70. De todas essas praças, a da Sé é a mais utilizada, a que tem maior visibilidade, maior escala e a primeira que sofreu ampla reforma. Da década de 70 para cá, houve uma série de avanços e conquistas em relação à acessibilidade.

Essa praça teve reformulação geral recentemente e incluiu os conceitos do Desenho Universal. Ela se configura como um bom exemplo de aplicação deste conceito, apresentando aspectos estéticos, acessíveis e funcionais muito interessantes. Ainda que tenham ocorridos alguns equívocos, a reforma proporcionou boas soluções, as quais serão apresentadas a seguir. 


\section{Metodologia do estudo de caso - Praça da Sé}

A delimitação física da Praça foi adotada para as análises de acessibilidade. No entanto, para melhor compreensão do significado da praça e de suas funções em relação à cidade, fez-se análise do entorno imediato, através de visitas e de fotos aéreas, considerando as inter-relações com o Metrô (Companhia Metropolitana de São Paulo).

A primeira etapa consistiu na busca de dados históricos relevantes sobre o local e de informações sobre os motivos e os responsáveis pela reforma. As consultas bibliográficas foram importantes durante esse processo, destacando-se Bartalini (1998), para entender o projeto inicial e as relações da Sé com o entorno. Pesquisas ao site da Prefeitura de São Paulo e de imprensa também foram fontes de informações.

Num segundo momento, houve o contato com a Empresa Municipal de Urbanização (EMURB), responsável pela reforma. As informações a respeito das diretrizes de projeto, documentação gráfica e autorização para visitar o canteiro de obras, foram fornecidas na entrevista com a arquiteta coordenadora Sra. Cristina T. S. Laiza. 
Durante as obras de reforma, em dezembro de 2006, fez-se a primeira visita ao local. Nessa ocasião realizou-se o primeiro roteiro fotográfico, acompanhado de explanações do engenheiro responsável pela obra da Praça da Sé, Sr. Roberto Steger.

A partir dos dados de projeto, documentação gráfica fornecida pela EMURB e o roteiro fotográfico preliminar, as análises de desempenho técnico foram iniciadas. A EMURB respondeu prontamente às dúvidas encontradas durante esse processo.

Após a inauguração da obra, em março de 2007, outro roteiro fotográfico foi realizado, com medições e constatações de qualidade e exatidão na execução, balizadas pelas recomendações da Norma Brasileira de Acessibilidade (NBR 9050/2004) e legislações.

Para este estudo de caso, não foram aplicados todos os preceitos da Avaliação Pós-ocupação, como utilização de chek list, análise de satisfação do usuário e aplicação de questionários, processo que requereria mais tempo. Os questionários, por exemplo, deveriam ser aplicados a um número de pessoas que representasse universo suficiente para obter resultado estatístico confiante. Embora esta análise de estudo de caso tenha o caráter de avaliação técnica, não se trata de um olhar específico de Avaliação Pós-ocupação. 
Mesmo utilizando parte destes métodos, a análise visa trazer um panorama das condicionantes de projetos e conseqüentes resultados para a acessibilidade, para a paisagem e para a inclusão.

Outras praças do Metrô que foram visitadas, para comparações das questões de acessibilidade, não possuíam soluções que garantissem plena circulação e visitação em toda a área de forma autônoma, como por exemplo, as Praças Ana Rosa, Liberdade e Santa Cecília.

Nesse estudo, baseado na NBR9050/2004, foram encontradas boas soluções e também problemas de acessibilidade. Os quais apontados e encaminhados à EMURB, que aceitou verificar essas

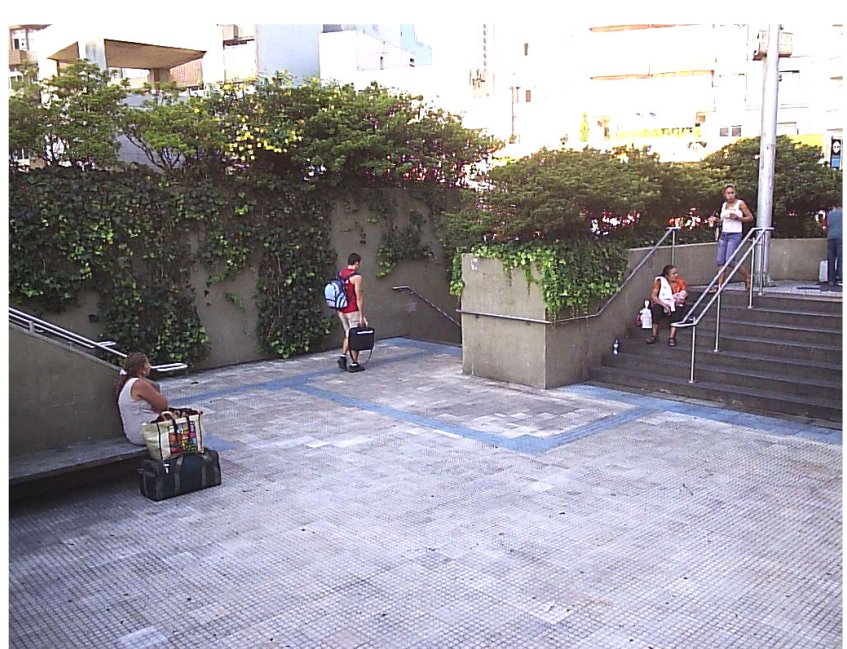

Figura 22 - Praça da Liberdade - acesso à plataforma do Metrô. Observa-se a utilização de piso tátil direcional para orientação de pessoas com deficiência visual, porém os corrimãos não estão instalados em 2 alturas e não existe opção ao acesso de cadeirantes pela praça. 


\section{Histórico da Praça da Sé}

O Largo da Sé data do início da formação da cidade de São Paulo. As Igrejas da Sé e de São Pedro, localizadas no Largo, foram demolidas em 1911 e 1912, para que a Praça tivesse seu tamanho ampliado em 5 vezes. Essas reformas fizeram parte das transformações ocorridas no início da República, momento em que ruas foram alargadas e as redes de luz e água foram instaladas ${ }^{9}$.

A Praça da Sé, desde o início foi local de intenso movimento em função das igrejas. A Catedral atraia grande número de pessoas para as missas e procissões.

A Catedral como é atualmente, foi inaugurada em 1952, junto com as reformas urbanísticas da Praça em comemoração ao 40 Centenário da Cidade ${ }^{10}$.

Em 1934, a Praça recebeu o Marco Zero da Cidade de São Paulo. Na década de 70 passou por reforma em função da Estação Sé de Metrô. Nessa época incluiu-se a Praça Clóvis Beviláqua como parte 
da Praça da Sé e em 1978 foi inaugurada com 50 mil metros quadrados ${ }^{11}$.

Segundo Bartalini (1988), os recursos financeiros disponíveis para as obras do Metrô eram fartos e davam condições para realizações e transformações urbanísticas. No caso da Praça da Sé, as demolições realizadas não eram necessárias para a construção da praça e da estação, mas elas ocorreram para que ali se obtivesse um grande espaço.

De acordo com o autor, a praça "possui uma carga simbólica e um conteúdo popular, onde se acumulam o político, o religioso e o cotidiano profano".

Ressalta ainda, o autor, que o primeiro anteprojeto da praça foi feito pelo Metrô, e o estudo dos espaços foi solicitado ao paisagista Roberto Burle Marx. Em decorrência da importância urbanística do local, a Empresa Municipal de Urbanização (EMURB) desenvolveu especial interesse, passando a tomar a frente do projeto.

A Praça foi então, construída com espelhos d'água, quedas d'água, jardineiras com acabamento em concreto e instalou-se

${ }_{11} \quad$ http://sampacentro.terra.com.br/textos.asp?id=106\&ph=2. Acesso em out/2006. 
luminárias ornamentais. Palmeiras de porte considerável, segundo Bartalini (1988), foram trazidas do Canal do Tamanduateí, para que o local tivesse aparência de "massa verde".

A Praça foi inaugura em fevereiro de 1978 com uma grande festa. Após a inauguração, grandes nomes da escultura fizeram trabalhos para a Praça, de acordo com levantamento da EMURB.

Além do Marco Zero, a Sé possui 15 esculturas e obras de arte, relacionadas a seguir.

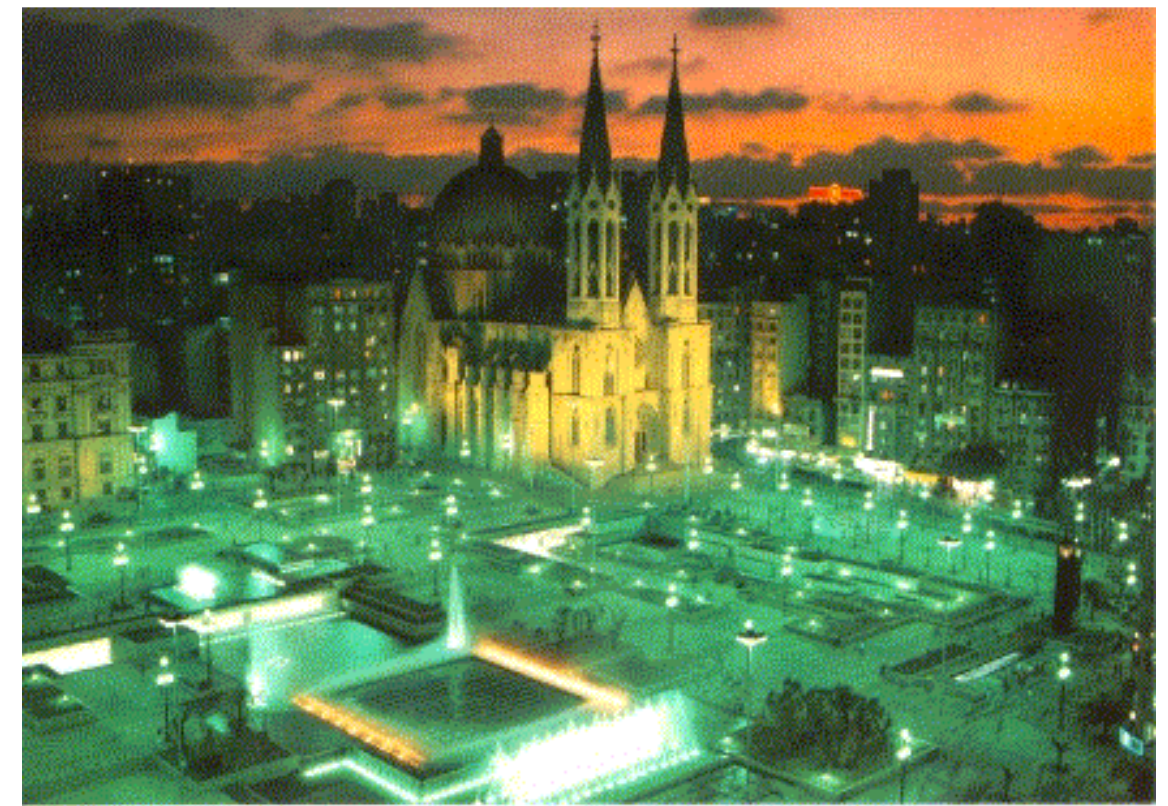

Figura 23 - Praça da Sé. Disponível em: http:// www.braziliantravel.com. 


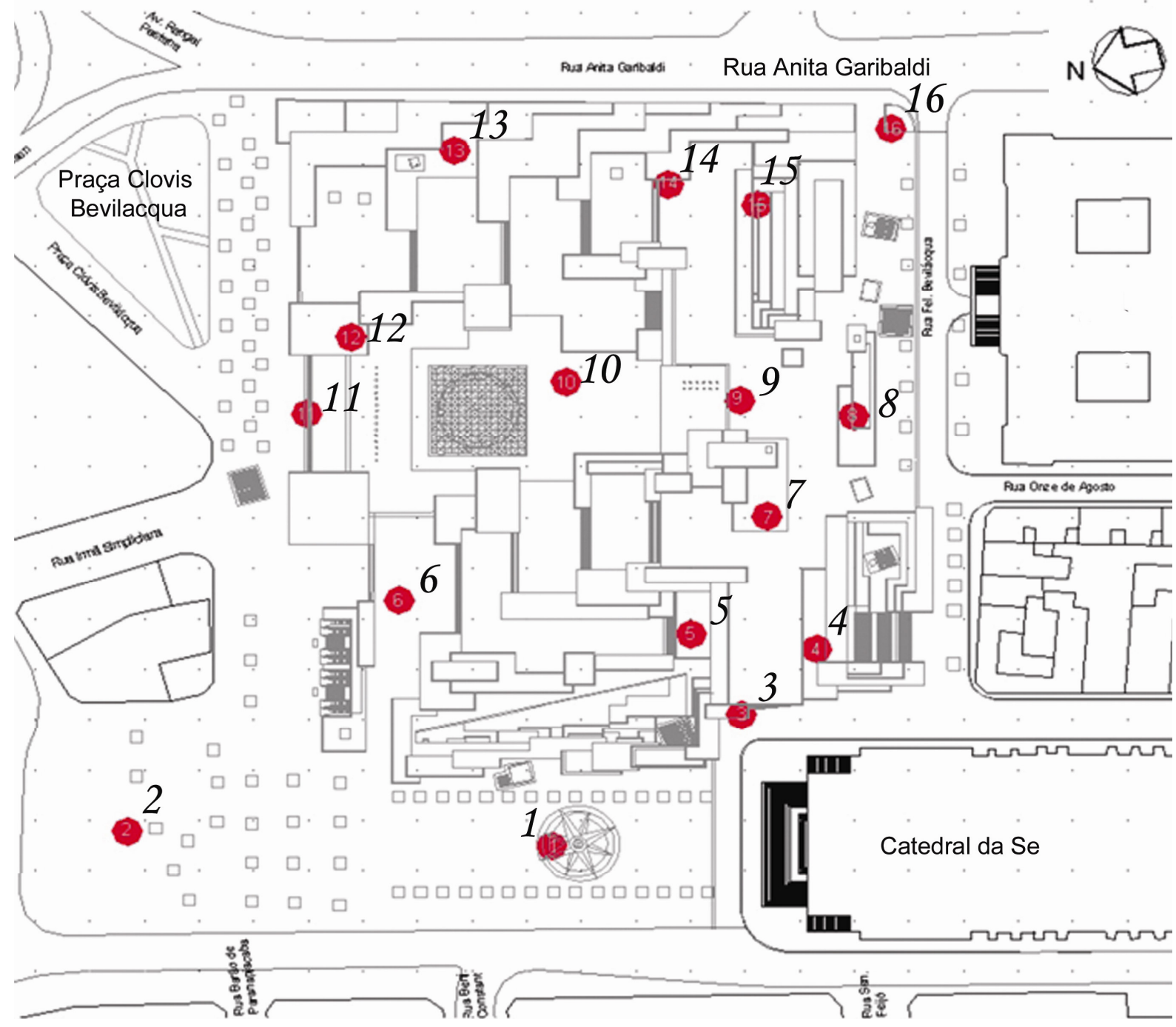

Figura 24 - Mapa das esculturas - imagem base obtida em: EMURB - Praça da Sé. Requalificação do Espaço Urbano. Apresentação em Power Point.
1. Marco Zero - J. G. Villim, A. R. Neto

2. José de Anchieta - Heitor Usai

3. Totem da Sé - Domenico Calabrone

4. Sem título - M. Cravo Jr.

5. Garatuja - Marcelo Nitsche

6. Sem título - Amílcar de Castro

7. Diálogo - F. Weissmann

8. Os Pássaros $-F$. Leinèr

9. Espaço Cóstimo - Y. Toyota

10. Condor - Bruno Giorgi

11. Emblema de São Paulo - R. Valentim

12. Vôo - Caciporé Torres

13. Sem Título - José Resende

14. Nuvem sobre a Cidade - N. Vlavianos

15. Sem título - Sérgio Camargo

16. Satélite $-F$. Stockinger

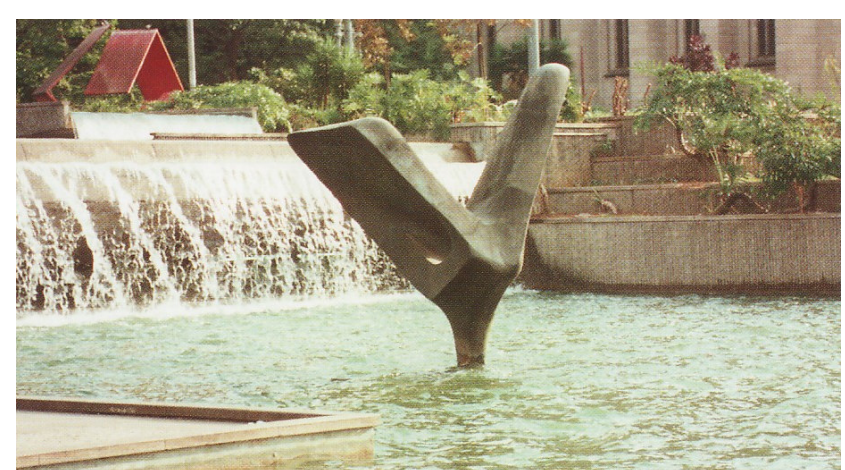

Figura 25 - "CONDOR" - Escultura de Bruno Giorgi. Foto: EMURB - Praça da Sé. Requalificação do Espaço Urbano. Apresentação em Power Point 
Na Praça da Sé, o espaço corresponde à antiga Praça Clóvis Beviláqua, o atrativo principal é um grande espelho d'água, que após a inauguração, em dias quentes, era muito visitado e até mesmo utilizado.

Entre o Palácio da Justiça e a antiga Praça Clóvis Beviláqua a diferença de nível é de $7 \mathrm{~m}$ e foi trabalhada com desníveis escalonados de aproximadamente $1 \mathrm{~m}$ de altura, com a intenção de criar espaços reservados à margem do fluxo. Estes espaços geométricos remetem, segundo Bartalini (1988), às formas da Praça do Auditórium Forecourt de Lawrence Halprin, Estados Unidos da América (EUA), 1961.

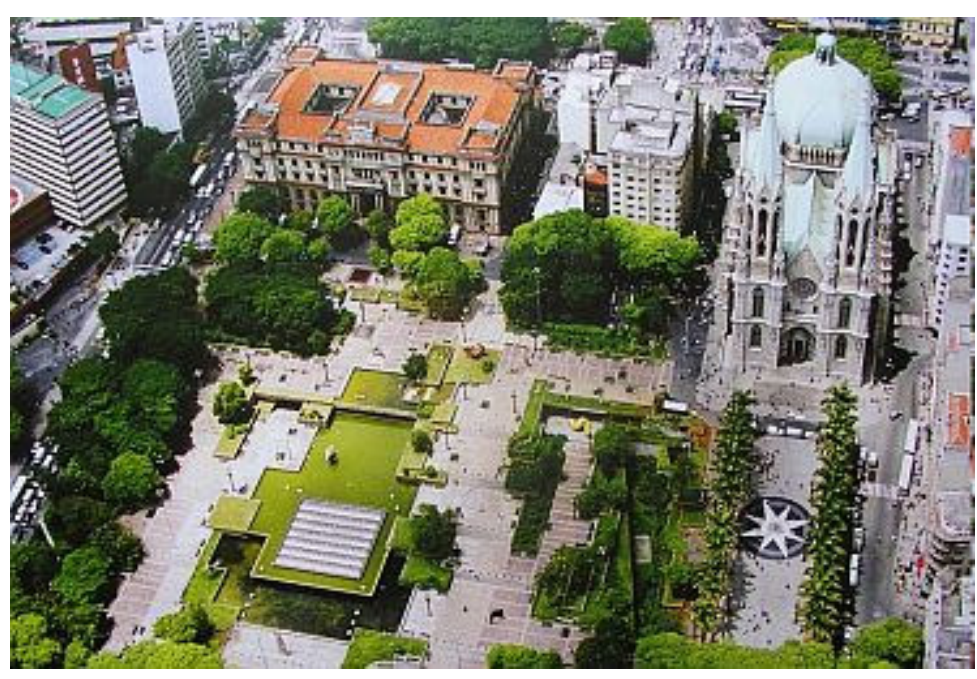

Figura 28 - Praça da Sé.

Disponível em:

http://www.guiadasemana.c

om.br/photos/event/p-

praçadase r.jpg

Acesso em 01/2008.

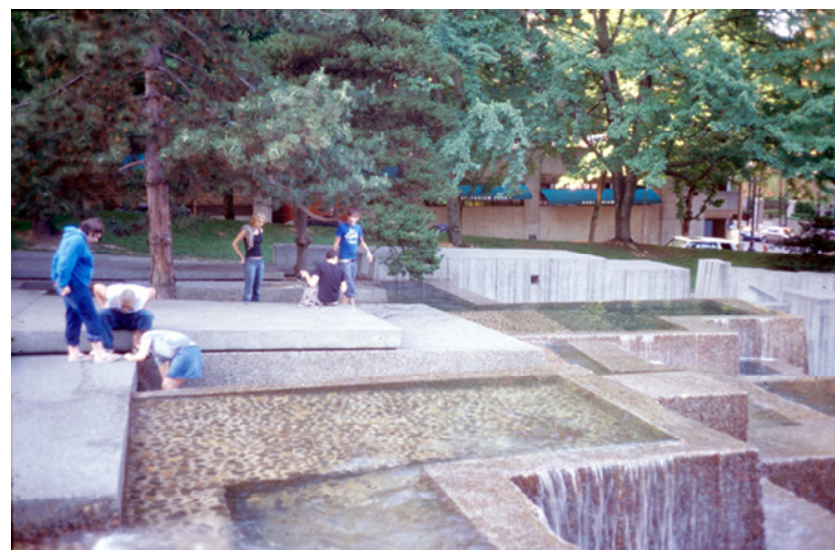

Figura 26 - Praça do Auditórium Forecourt de Lawrence Halprin, EUA, 1961.

http://www.sol.slu.se.htm

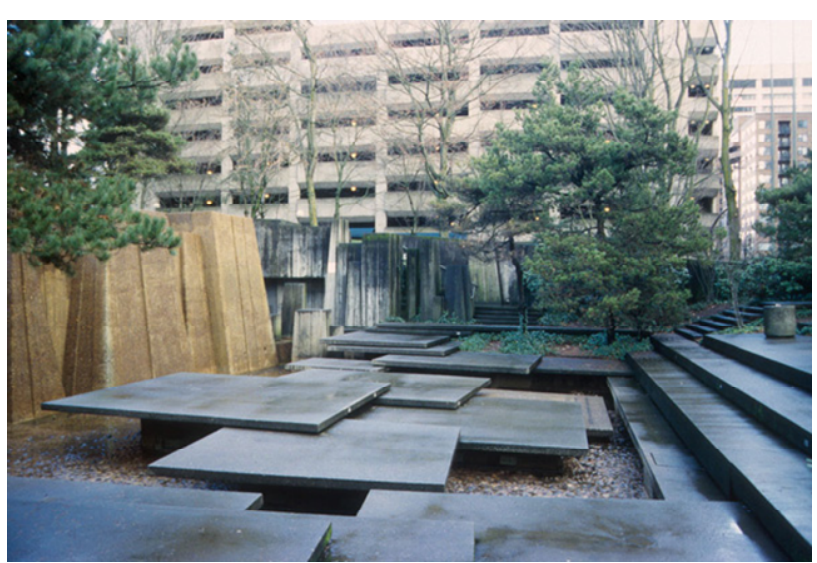

Figura 27 - Praça do Auditórium Forecourt de Lawrence Halprin, EUA, 1961.

http://www.sol.slu.se.htm 
A Praça da Sé, assim como a da República, é retangular e possui um edifício que domina o espaço. A área na frente da Catedral é ampla e pavimentada e se opõe aos recantos e caminhos formados pelo restante da praça, de acordo com Bartalini (1988).

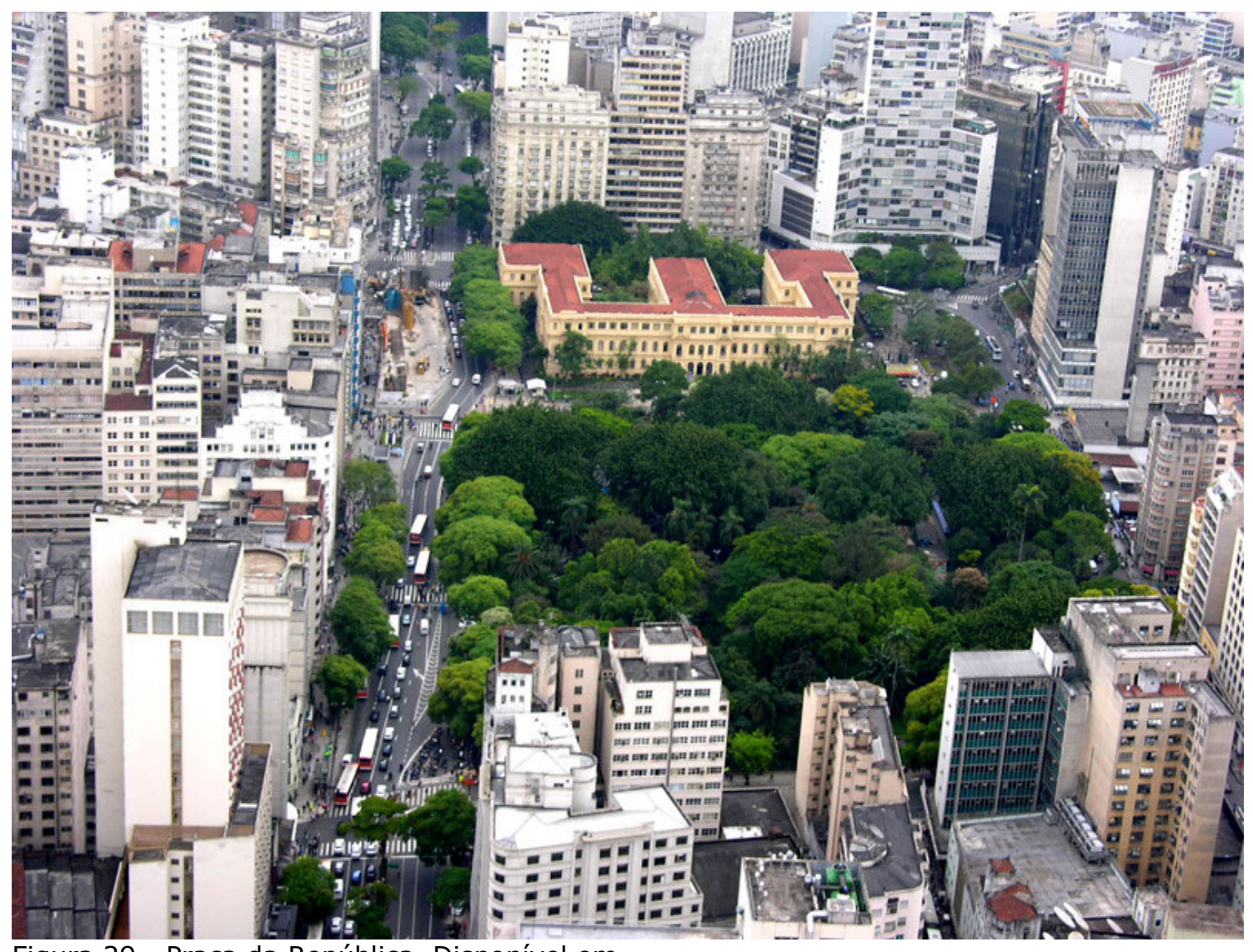

Figura 29 - Praça da República. Disponível em

http://www.cidadedesaopaulo.com/touraereo/fotos/praca_republica.jpg. Acesso em fev/2008 


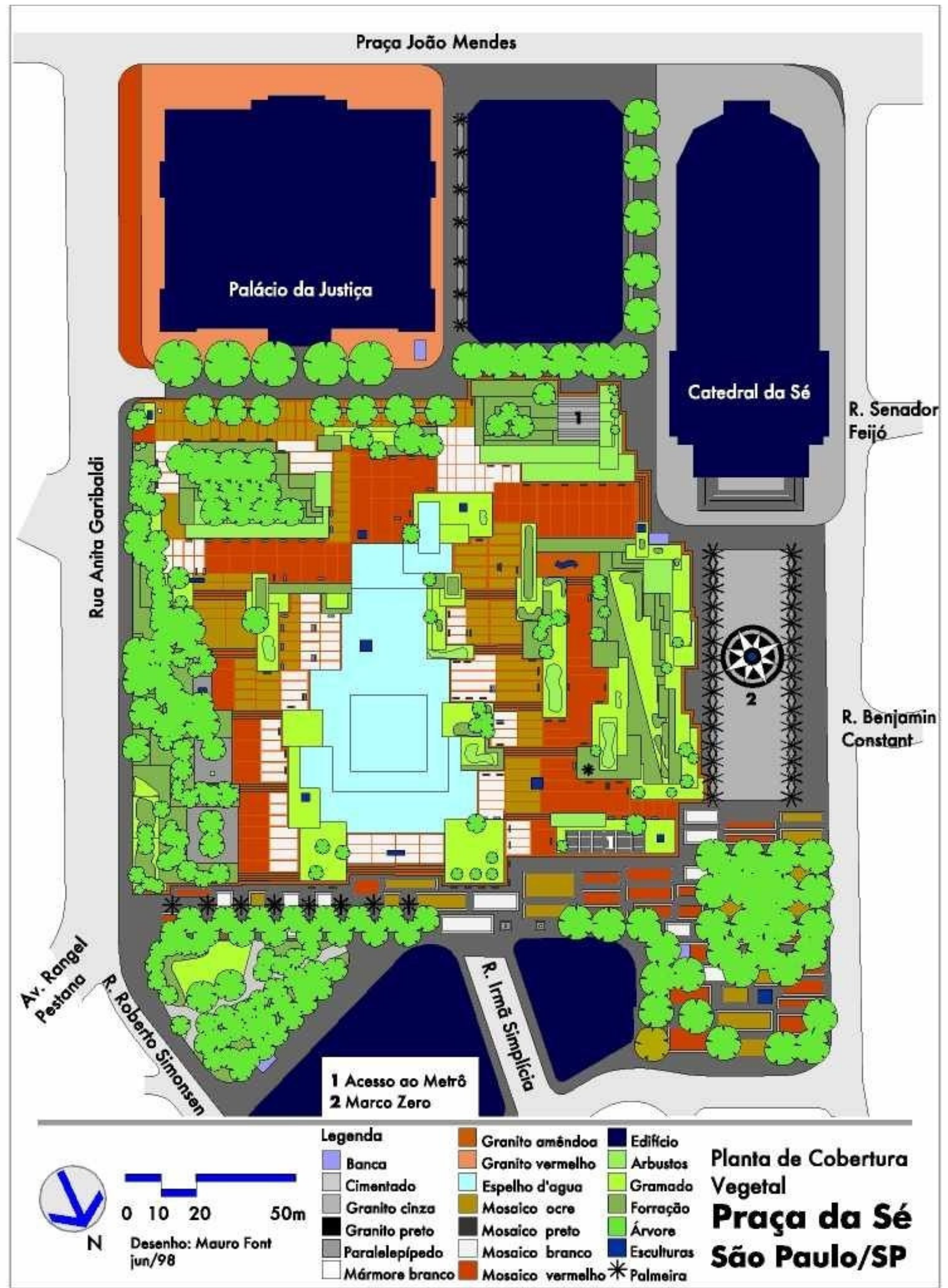

Figura 30 - EMURB - Praça da Sé. Requalificação do Espaço Urbano. Apresentação em Power Point. Desenho original - Quadro do Paisagismo no Brasil - QUAPÁ 
Desde a sua construção, a Praça da Sé é local de manifestações políticas e artísticas. O uso religioso ainda é grande, embora não o seja como no início do século passado. Segundo a Sampacentro ${ }^{12}$ :

1914 - Comício de 10 de maio, organizado por sindicatos;

1915 - protestos contra a Primeira Guerra Mundial;

1922 - missa campal em comemoração ao Centenário da Independência;

1932 - manifestações e protestos contra a ditadura de Getúlio Vargas;

1945 - ato público pela redemocratização do país;

1984 - primeiro Comício pelas "Diretas Já".

Atualmente, de acordo com estudos da Prefeitura de São Paulo, cerca de 1,5 milhões de pessoas passam pela Praça, diariamente. $\mathrm{Na}$ Estação da Sé circulam 100 mil pessoas por hora, em horário de pico, segundo o Metrô.

12 Disponível em : http://sampacentro.terra.com.br/textos.asp?id=106\&ph=2. Acesso em Maio/2007. 
Desde o fim do século XIX, a Praça foi espaço para o comércio informal. No passado, essa atividade era exercida por negros livres.

Nos últimos anos a região foi tomada por vendedores ambulantes, em função do enorme fluxo de pessoas que transitam pelo local. Porém, o comércio informal foi reduzido intensamente, depois que a Prefeitura de São Paulo iniciou o processo de requalificação da área ${ }^{13}$. Atualmente, apenas os engraxates, credenciados pela Prefeitura, permanecem no local.

Para Bartalini (1988), a circulação é um importante fator na formação do espaço urbano. No caso do Metrô, as estações são pontos de aglomeração e dispersão nos embarques e desembarques, gerando usos diversos, como o comércio, serviços e a mendicância.

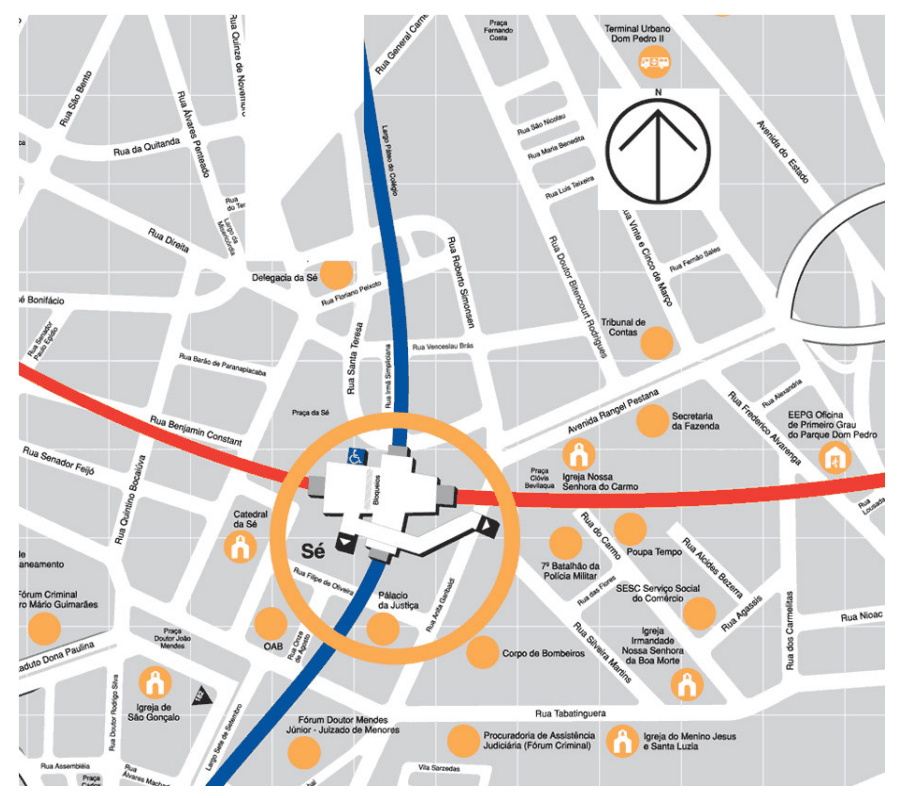
As praças do Metrô se diferenciam das praças de bairro por serem Figura 31 - Mapa dos arredores da estação Sé do Metrô freqüentadas não apenas por moradores do entorno, mas também por pessoas que somente passam por ali.

13 Disponível em : http://sampacentro.terra.com.br/textos.asp?id=106\&ph=2. Acesso em Maio/2007. 


\section{Reforma da Praça da Sé}

Em função do Programa de Reabilitação da Área Central da Prefeitura de São Paulo, na gestão do Prefeito José Serra, a proposta de reforma da Praça foi desenvolvida, visando novos usos e fluxos de pessoas. Segundo a arquiteta Cristina Laiza, integrante da equipe de arquitetos da EMURB que idealizou essa reformulação, o projeto procurou promover a circulação dentro da Praça, evitando a segregação espacial causada pela configuração do projeto original, que deixava boa parte da praça vazia.

A análise desenvolvida pela EMURB apontou problemas de permeabilidade de fluxo de pedestres, em função das barreiras criadas pelas floreiras. Verificou-se a predominância de circulação no eixo norte-sul, especialmente entre a esplanada da Catedral e o Palácio da Justiça, no entanto, na direção oeste, rumo à Rua Anita Garibaldi, o fluxo de pedestres era interrompido pelas altas jardineiras existentes. Os acessos norte e sul do Metrô, absorviam e criavam fluxos nesse sentido, enquanto que a circulação leste-oeste, interna da praça, encontrava-se obstruída pela presença das floreiras altas. 


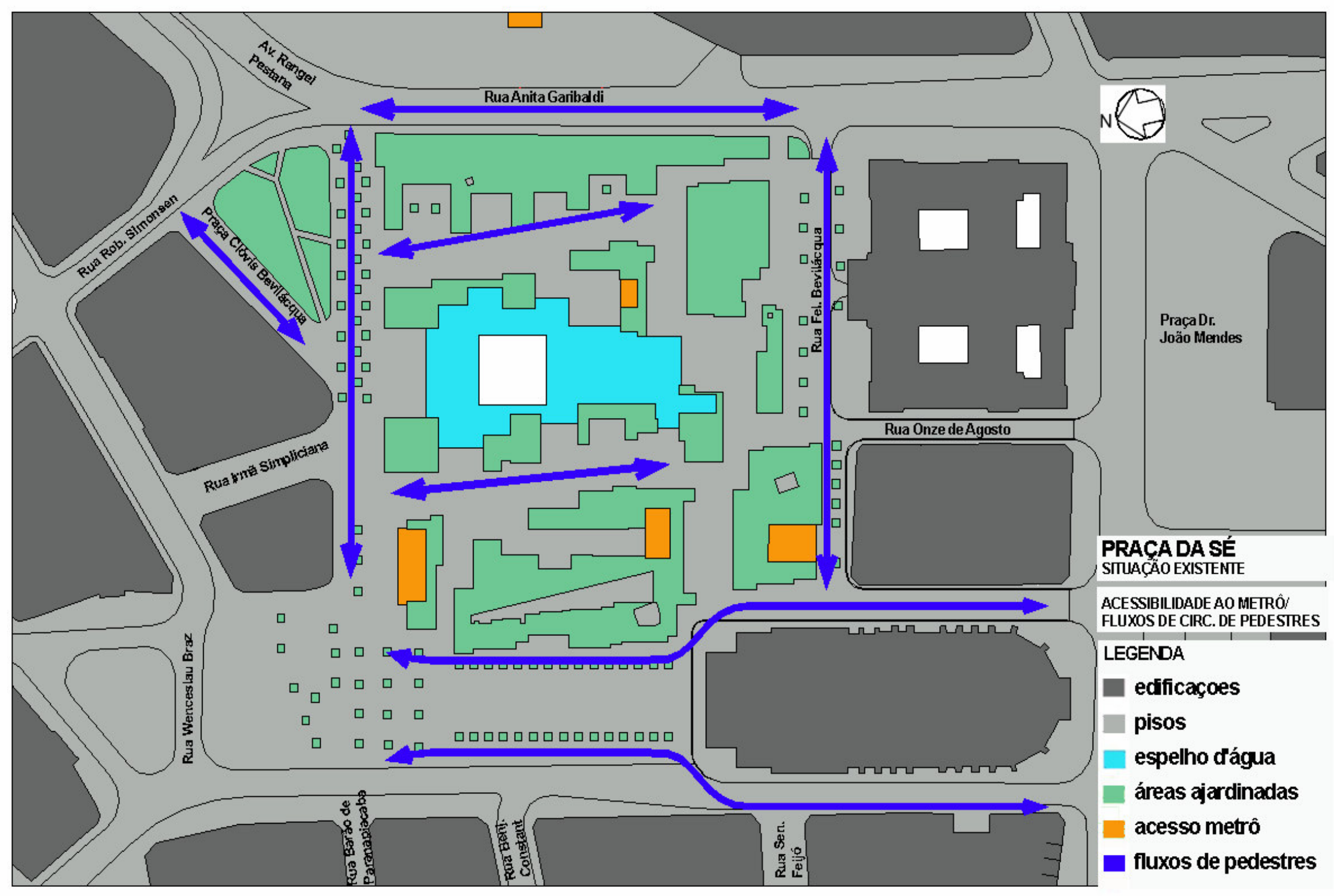

Figura 32 -Imagem - EMURB - Praça da Sé. Requalificação do Espaço Urbano. Apresentação em Power Point. 
A falta de segurança foi outro item apontado, sobretudo pelas barreiras visuais, decorrentes das altas floreiras e do excesso de vegetação em alguns canteiros, dificultando a compreensão e o policiamento do espaço da praça.

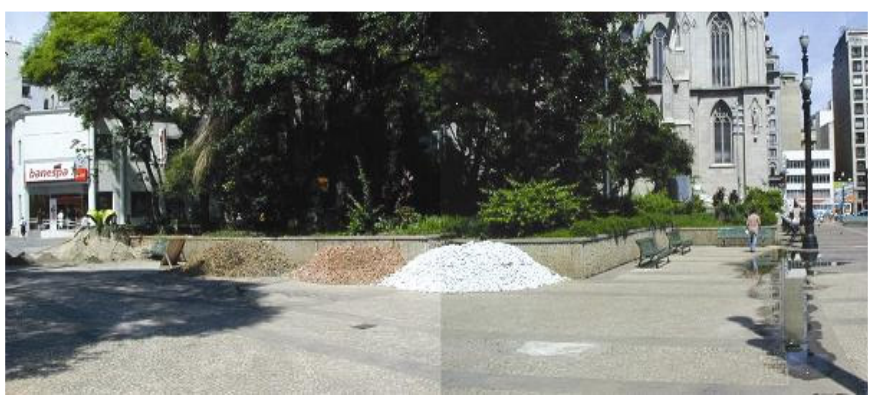

Figura 33 - EMURB - Praça da Sé. Requalificação do Espaço Urbano. Apresentação em Power Point. Canteiro com densa vegetação.

Problemas relacionados a questões de acessibilidade também foram observados nesse estudo, como por exemplo, a presença de escadarias ao longo das rotas de fluxo e problemas na apreensão do espaço, causados pelas altas floreiras.

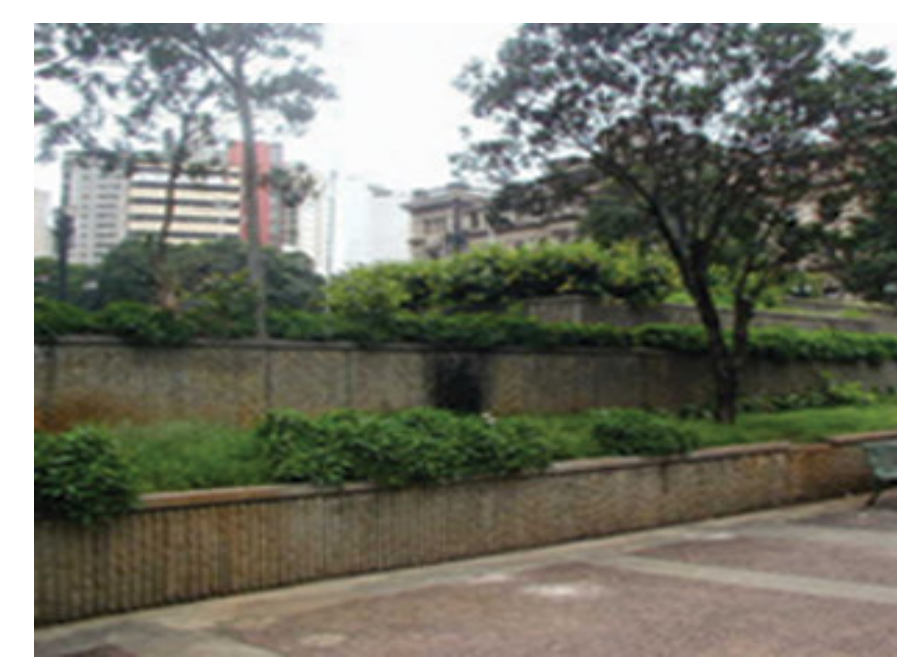

Figura 34 - EMURB - Praça da Sé. Requalificação do Espaço Urbano. Apresentação em Power Point. Altura excessiva das jardineiras. 


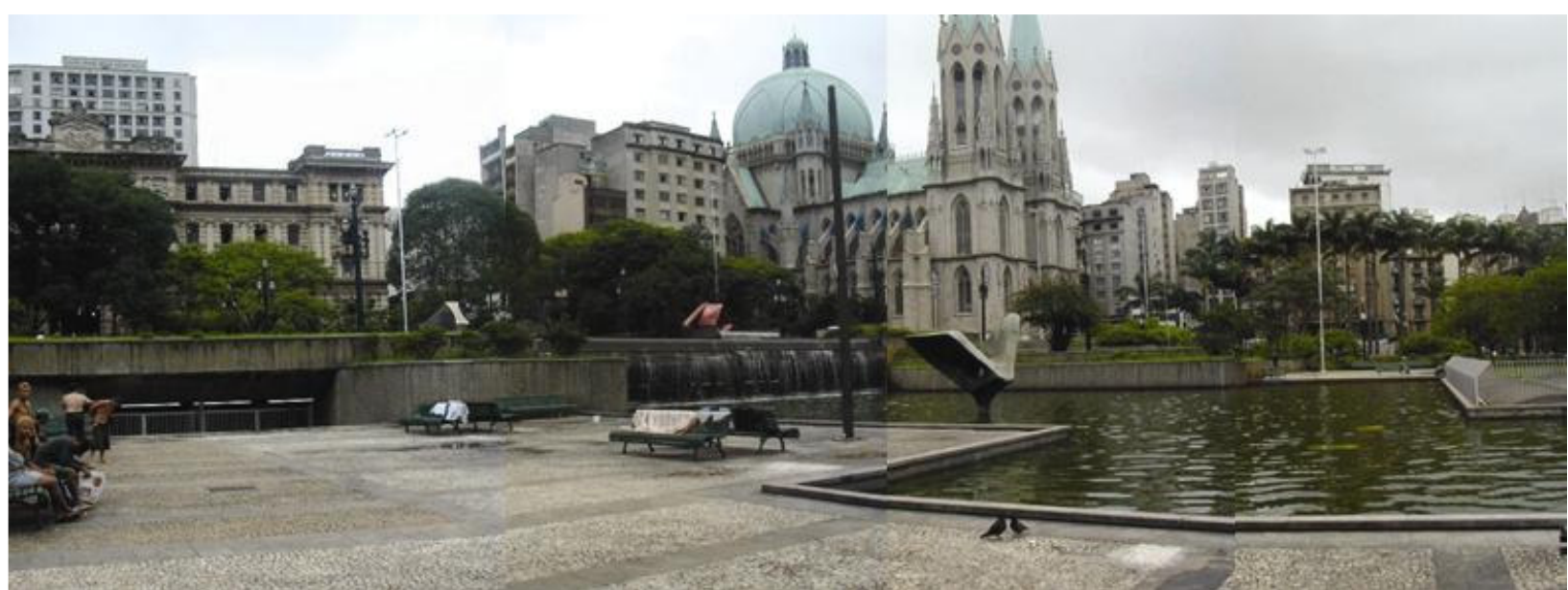

Figura 35 - EMURB - Praça da Sé. Requalificação do Espaço Urbano. Apresentação em Power Point. Entrada desativada do Metrô. Existência de floreiras altas e ocupação por moradores de rua.

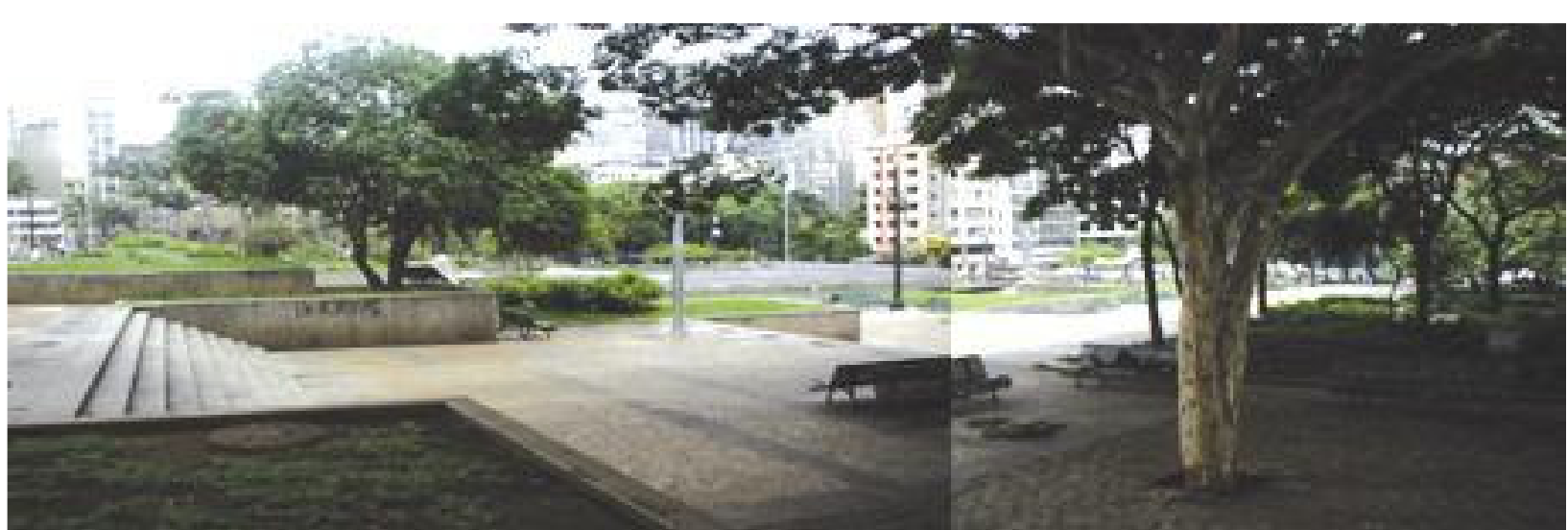

Figura 36 - EMURB - Praça da Sé. Requalificação do Espaço Urbano. Apresentação em Power Point. Escadarias. Não existiam rotas acessíveis. 
Como diretrizes de projeto, a EMURB adotou os seguintes itens:

- Transpor as barreiras criadas pelo espelho d'água e pela ventilação do Metrô, criando a circulação transversal.

- Proporcionar circulação transversal na praça para integrar os espaços, ampliar a apropriação das diversas áreas e garantir novas conexões com as entradas do Metrô.

- Ampliar áreas de circulação, através da eliminação de algumas jardineiras.

- Melhorar as travessias de pedestres, dificultadas pela presença de mobiliário urbano como postes, bancas de jornal e pontos de ônibus.

- Abrir os acessos desativados do Metrô e ampliar as áreas de recepção, por meio da retirada de algumas jardineiras;

- Possibilitar visualização das áreas de estar.

- Implantar rampas para pessoas com deficiência.

- Relocar esculturas para a reforma dos canteiros.

- Implantar iluminação de destaque. 
- Reestruturar e promover manutenção da vegetação, para evitar espaços obscuros.

- Implantar canteiros alagados para dificultar o contato direto com o espelho d'água, cuja água não é limpa.

A proposta da EMURB baseou-se nas seguintes premissas básicas:

- Trazer o fluxo de pessoas para dentro da praça, projetando rampas e passarelas a fim de permitir o fluxo transversal e diagonal de forma acessível (criação de rota acessível) ${ }^{14}$ por toda a praça e com entrada ao mezanino do Metrô, eliminando a necessidade de elevador.

- Eliminar algumas jardineiras e rebaixar outras, para permitir melhor visualização de toda a área e facilitar as condições de acessibilidade.

\footnotetext{
14 Segundo a NBR 9050/2004, rota acessível é: "Trajeto contínuo, desobstruído e sinalizado, que conecta os ambientes externos ou internos de espaços e edificações, e que possa ser utilizado de forma autônoma e segura por todas as pessoas, inclusive aquelas com deficiência. A rota acessível externa pode incorporar estacionamentos, calçadas rebaixadas, faixas de travessia de pedestres, rampas, etc. A rota acessível interna pode incorporar corredores, pisos, rampas, escadas, elevadores etc.".
} 
- Fazer o manejo da vegetação e aumentar a quantidade de árvores em áreas que não sejam sobre as lajes do Metrô, para aumentar a permeabilidade da praça. Eliminar a vegetação arbustiva e trocar por forração de baixo custo e manutenção;

- Renovar a iluminação geral da praça para aumentar a sensação de segurança;

- Implantar de iluminação cenográfica de realce às obras de arte e de arquitetura, propiciando ponto de encontro turístico noturno;

- Promover a gestão profissional da praça através da união entre o poder público e a iniciativa privada, além do desenvolvimento de atividades culturais. 


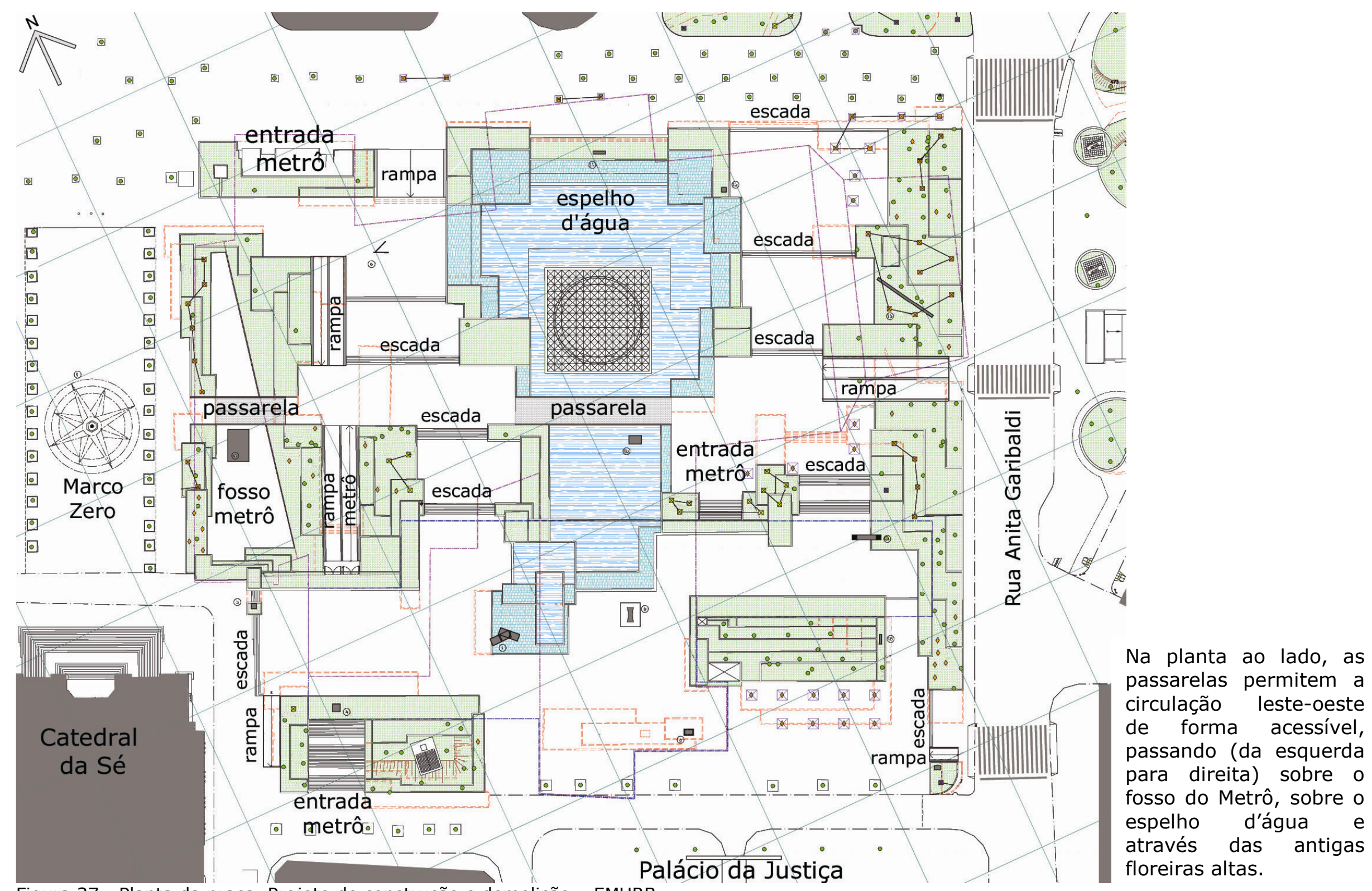

Figura 37 - Planta da praça. Projeto de construção e demolição - EMURB 
Na planta de reforma da praça, na página anterior temos:

- o tracejado em cor de rosa, que representa as floreiras a serem demolidas, redesenhando os percursos;

- ao centro do desenho, a passarela criada sobre o espelho d'água, que permite o cruzamento em nível, sem perder a visualização desse elemento;

- à esquerda, a passarela que transpõe o fosso do Metrô, criando um novo eixo de circulação. Esse eixo começa (do lado direito) com rampa para vencer o desnível inicial do percurso e se mantém praticamente em nível, garantindo rota acessível até o Marco Zero.

- No eixo norte-sul (planta com norte orientado para cima), do lado esquerdo e do lado direito do espelho d'água, foram reabertas as entradas do Metrô. Para estas passagens, floreiras foram demolidas e todo o trajeto pode ser feito através de rampas ou escadarias. No mesmo sentido, porém do lado direito da planta, o eixo norte-sul possui apenas escadas, o que não se torna um 
problema, porque existe entrada acessível à esquerda do espelho d'água.

A proposta previu a utilização de piso tátil de alerta em todas as mudanças de nível, seja em rampas ou escadas, a utilização de corrimãos nas rampas e sinalização de mobiliário urbano ${ }^{15}$.

Considera-se então, que no projeto de reforma da Praça existem rotas acessíveis, tanto no sentido leste-oeste como no sentido norte-sul. Em todo o contorno da praça, o passeio público também atende aos parâmetros de acessibilidade, utilizando os rebaixamentos nas travessias e piso com inclinação e largura, que seguem os parâmetros da NBR 9050/2004 e às recomendações do Programa Passeio Livre ${ }^{16}$ da Prefeitura de São Paulo.

$15 \quad$ No caso de aparelhos telefônicos (orelhões) ou qualquer outro objeto suspenso, cujo volume suspenso seja maior que sua base, deverá ser sinalizado com piso tátil de alerta, para que a pessoa com deficiência visual não sofra acidentes (colisão).

16 Para Passeio Livre ver Capítulo 6. 


\section{Roteiro fotográfico durante obra de reforma da Praça da Sé}

O roteiro foi realizado em 08 de dezembro de 2006 durante as obras de reforma da Praça da Sé, e as fotos foram tiradas pela autora do trabalho.

$\mathrm{Na}$ foto ao lado, implantação de rampas junto às escadas de acesso à entrada do Metrô reativada.

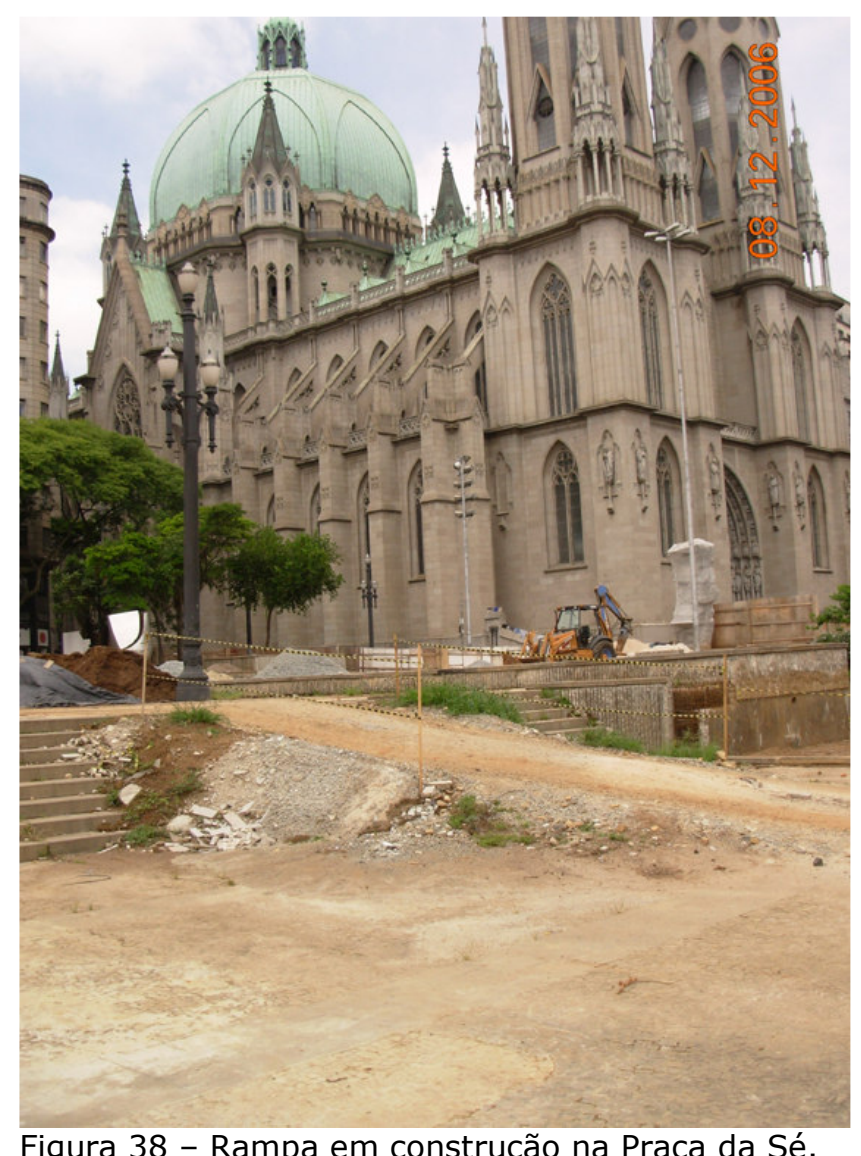


$\mathrm{Na}$ foto superior, pode-se ver a reforma para reativação da entrada da Estação do Metrô - piso refeito, floreiras rebaixadas.

A transposição do fosso do Metrô, com passarela em nível, pode ser observada na foto inferior.

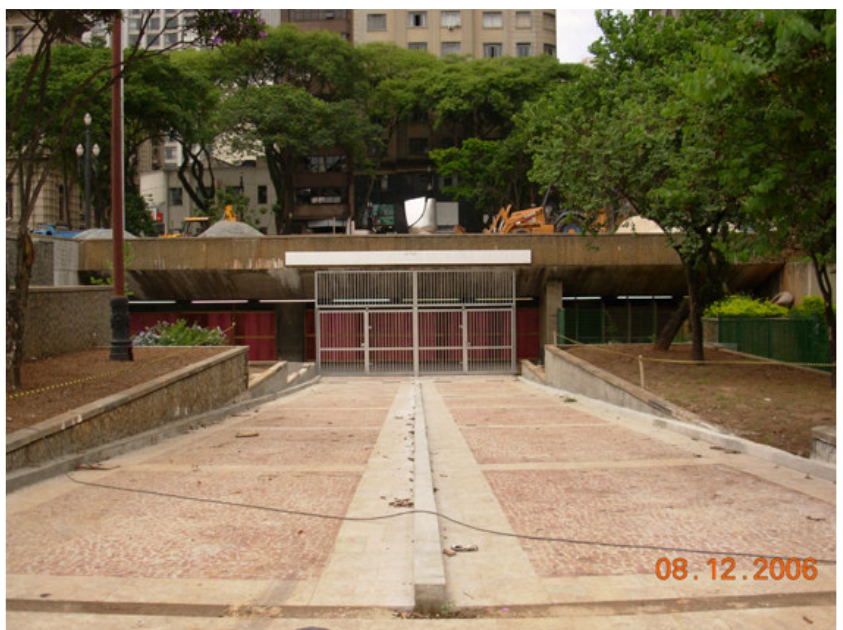

Figura 39 - Foto da rampa de entrada da Estação.

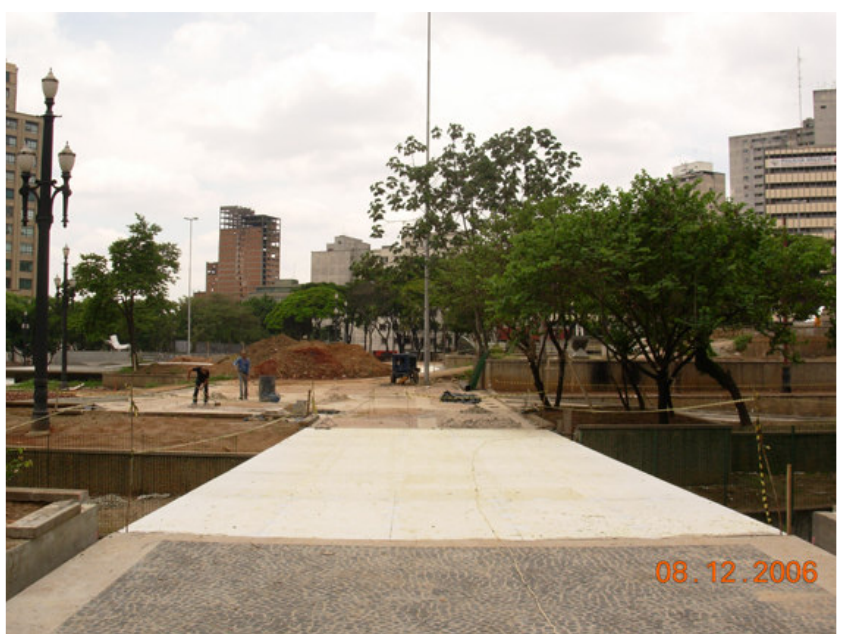

Figura 40 - Passarela sobre o fosso do Metrô. 
Ao lado direito superior, tem-se os conjuntos de rampas que atravessam as escadarias e cortam a Praça no sentido norte-sul, atendendo à entrada reativada do Metrô.

As grelhas de ventilação do Metrô não sofreram revisão. Como não estão na rota acessível, essas grelhas são aceitáveis. Não ocupam a largura integral do trajeto e, segundo a NBR9050/2004, não impedem a passagem, porque estão fora do fluxo principal de circulação. Porém, da forma como estão, apresentam riscos de acidentes, por exemplo, de prender cadeiras de rodas, porque o vão é maior do que $15 \mathrm{~mm}$ e por isso não está de acordo com a Norma.

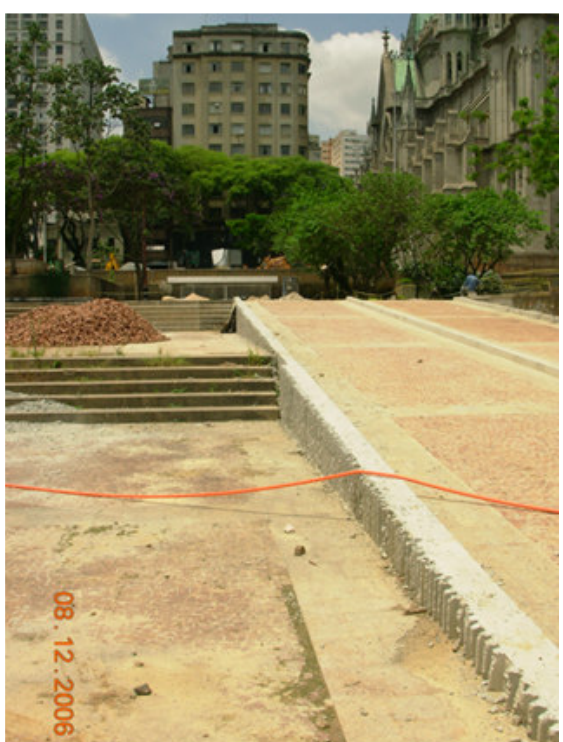

Figura 41 - Construção de uma das rampas da entrada reativada do Metrô.

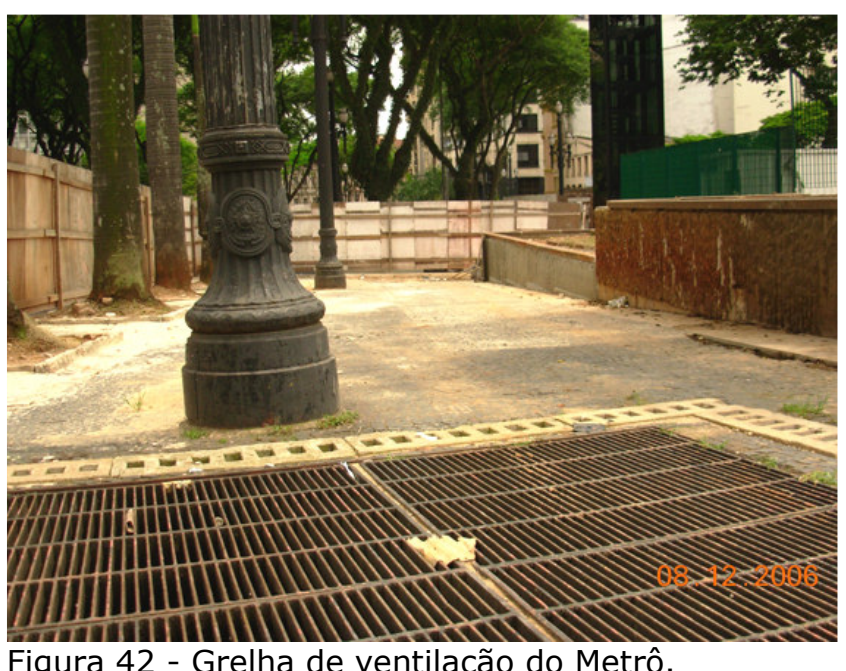

Figura 42 - Grelha de ventilação do Metrô. 
As floreiras da Praça foram rebaixadas e outras foram construídas para demarcar o caminho no sentido leste-oeste da praça e incentivar o uso desse percurso.

O piso original da Praça foi mantido e em locais onde houve alterações de traçado de circulação, completou-se com o mesmo padrão.

Próximo ao Palácio da Justiça, para melhor visualização do espaço, floreiras foram rebaixadas, como se pode ver na foto inferior.

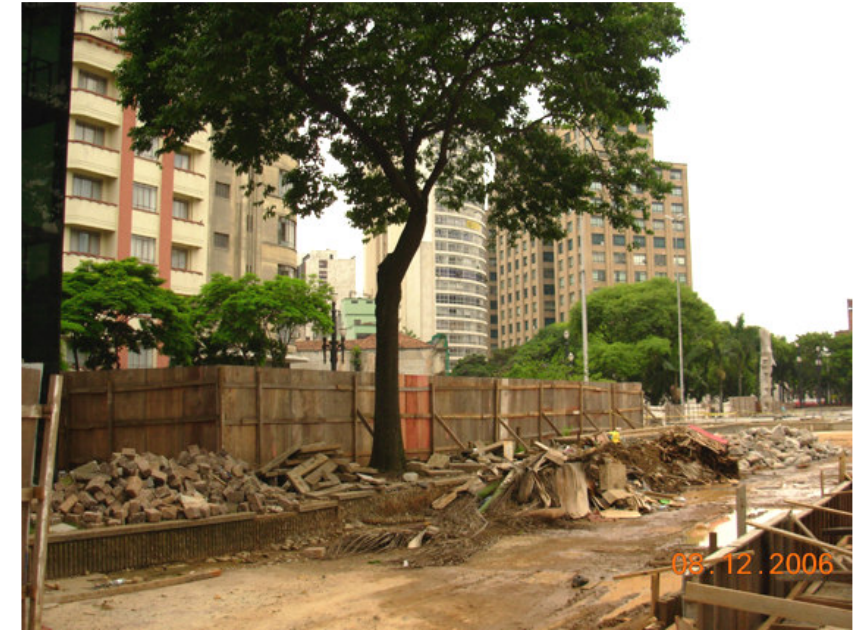

Figura 43 - Obras de construção de novas floreiras no eixo leste-oeste da Praça.

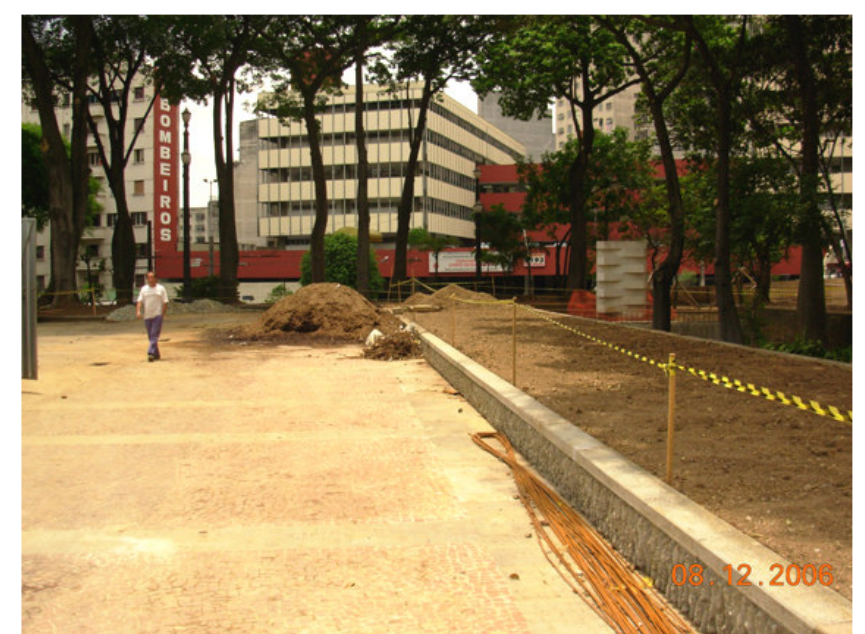

Figura 44 - Rebaixamento de floreiras em frente ao Palácio da Justiça. 
A passarela sobre o espelho d'água, sendo construída em nível, demarcando o eixo leste-oeste na implantação da rota acessível, pode se ver vista na foto superior.

Com as floreiras rebaixadas, pode-se observar a praça de forma mais ampla. Tem-se a visão total da Praça, em direção ao espelho d'água.

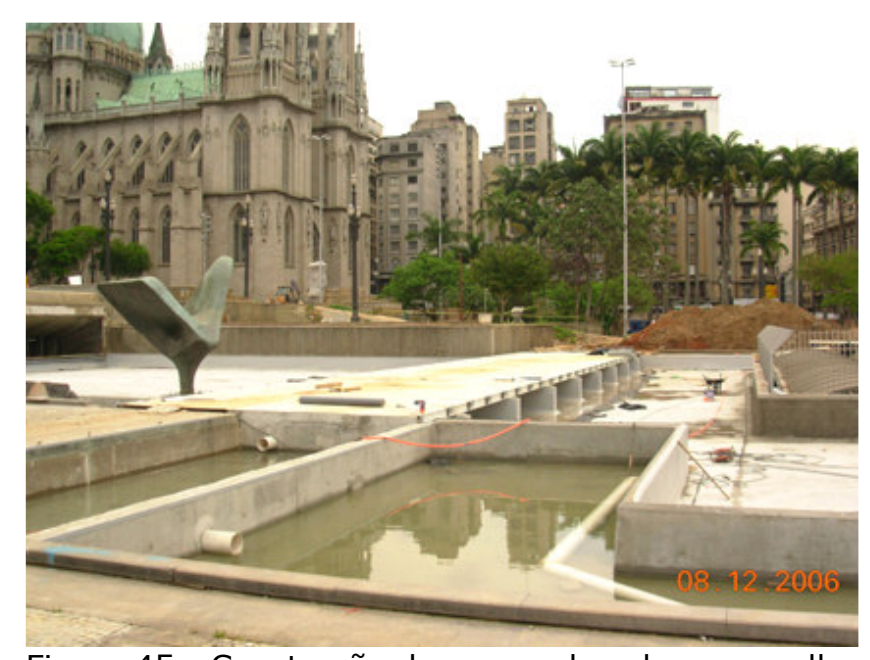

Figura 45 - Construção da passarela sobre o espelho d'água no centro da Praça da Sé.

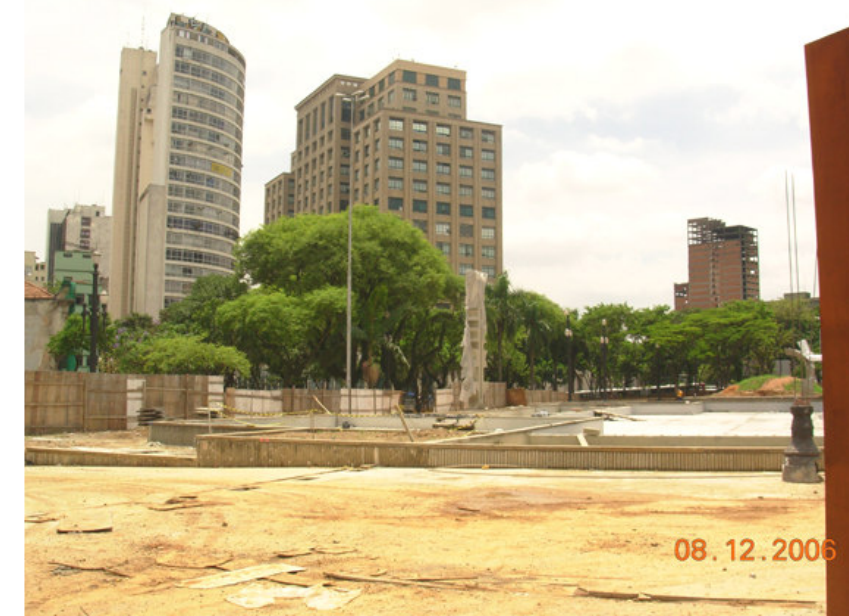

Figura 46 - Observação panorâmica da praça em obras, com as floreiras rebaixadas. 


\section{Roteiro fotográfico após a obra da Praça da Sé}

Em 24 de março de 2007, ao final da reforma da Praça da Sé, realizou-se o roteiro fotográfico descrito a seguir.

O piso mostrado na foto ao lado, seguiu o mesmo padrão de desenho e especificação existentes.

A rampa, apresentada na mesma foto, tem $8,2 \%$ de inclinação, segundo projeto da EMURB. A NBR 9050/2004 determina que a inclinação máxima, para as condições de rampa como essa, é de $8,33 \%$. Portanto, sua porcentagem está abaixo da máxima permitida.

Quanto à sinalização, existe piso tátil de alerta nas mudanças

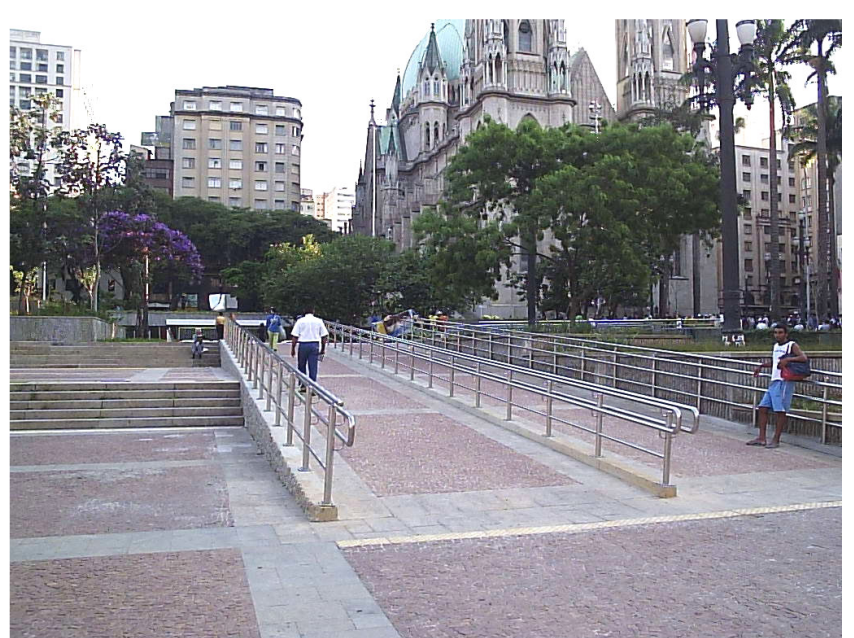

Figura 47 - Rampa do acesso após a reativação da entrada da Estação Sé do Metrô.

de nível de piso para pessoas com deficiência visual, conforme a NBR9050/2004.

Na rampa, as muretas têm corrimãos em duas alturas $(75 \mathrm{~cm}$ e $92 \mathrm{~cm})$, os quais atendem pessoas com baixa estatura ou em cadeiras de rodas, e crianças. Porém observou-se que falta patamar plano de descanso nas rampas, pois segundo a Norma, inclinações que variam entre $6,25 \%$ e $8,33 \%$ necessitam de patamares a cada $0,80 \mathrm{~m}$ de desnível. O desnível dessa rampa é de $1,90 \mathrm{~m}$. 
A entrada para o mezanino do Metrô foi reativada e na rampa instalou-se piso tátil de alerta nas mudanças de nível, e piso tátil de orientação para dar o rumo à entrada de pessoas com deficiência visual.

A inclinação da rampa $(7,3 \%)$ e os corrimãos ali instalados também atendem à Norma. Observou-se a falta de patamares planos de descanso, os quais deveriam existir, pois essa rampa tem desnível de 2,10m e neste caso, está em desacordo com a NBR9050/2004.

A passarela, que permite a travessia sobre o fosso da Estação, é sinalizada em suas extremidades com piso tátil de alerta, tem corrimãos em duas alturas e guarda-corpos em acrílico transparente, permitindo a visualização do local com segurança.

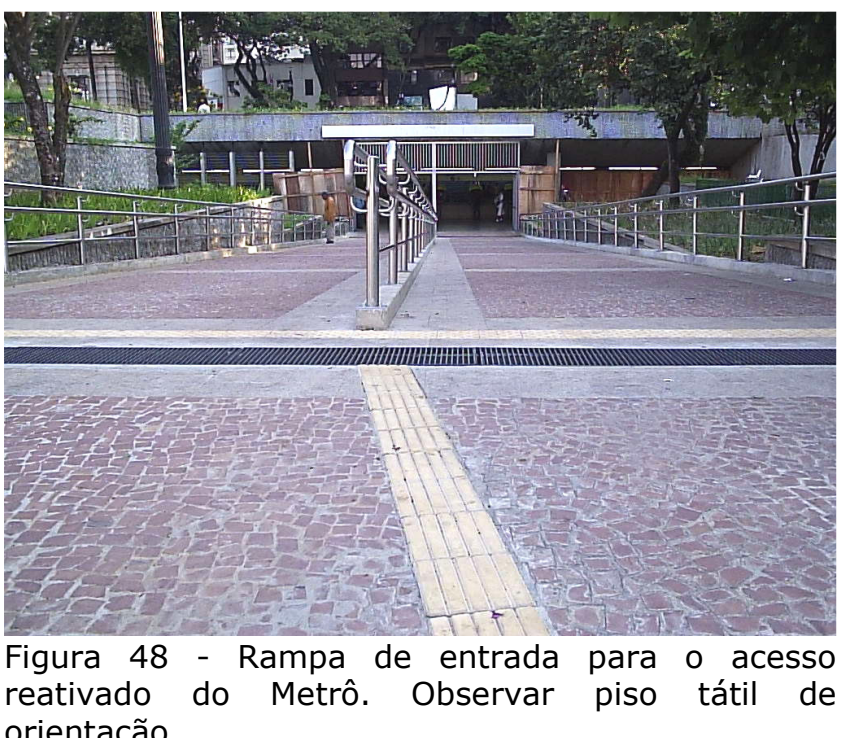
reativado
orientacão.

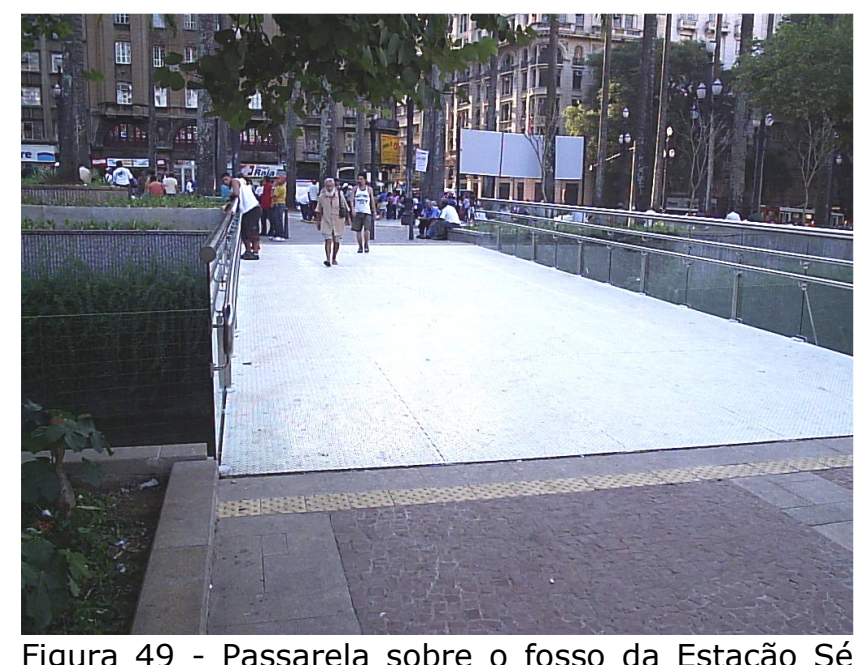
de Metrô. 
Os canteiros alagados foram construídos com muretas junto ao espelho d'água. Elas auxiliam no balizamento de pessoas com deficiência visual.

Ao lado da mureta da foto, pode-se observar a utilização do piso tátil direcional (textura em barras), para orientar o percurso e o piso tátil de alerta (textura em círculos) para avisar que existe a passarela em frente.

Construída sobre o espelho d'água, a passarela permite o fluxo leste-oeste na Praça de forma acessível.

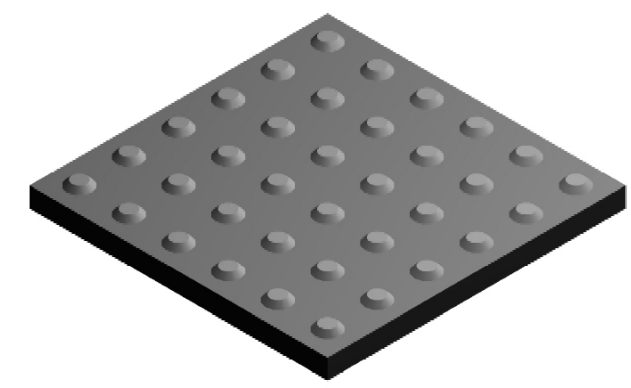

Piso Tátil de Alerta

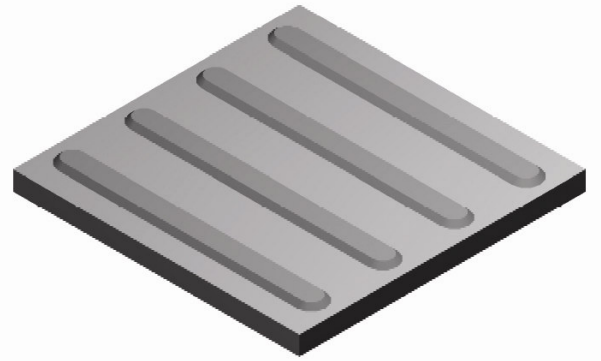

Piso Tátil de Orientação

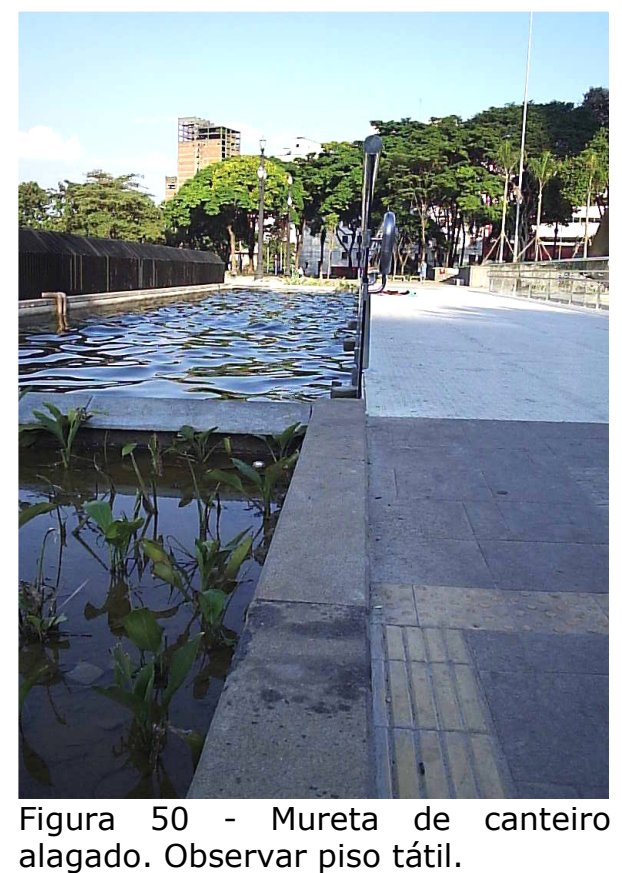

Figura 51 - Imagem dos pisos táteis - Informativo Técnico n.0 14 - USP Legal 
Os canteiros alagados que estão junto ao espelho d'água afastaram os pedestres do contato direto com a água, a qual, segundo a EMURB, não é tratada adequadamente para essa finalidade.

Na data da realização das fotos, alguns trechos da Praça ainda não estavam inteiramente prontos, como se pode observar na foto imediatamente ao lado.

A passarela sobre 0 espelho d'água tem dois corrimãos implantados nas alturas recomendadas pela NBR 9050/2004 (75cm e $92 \mathrm{~cm}$ ) e guarda-corpos em acrílico, permitindo visualização da queda d'água, a qual foi reativada na reforma.

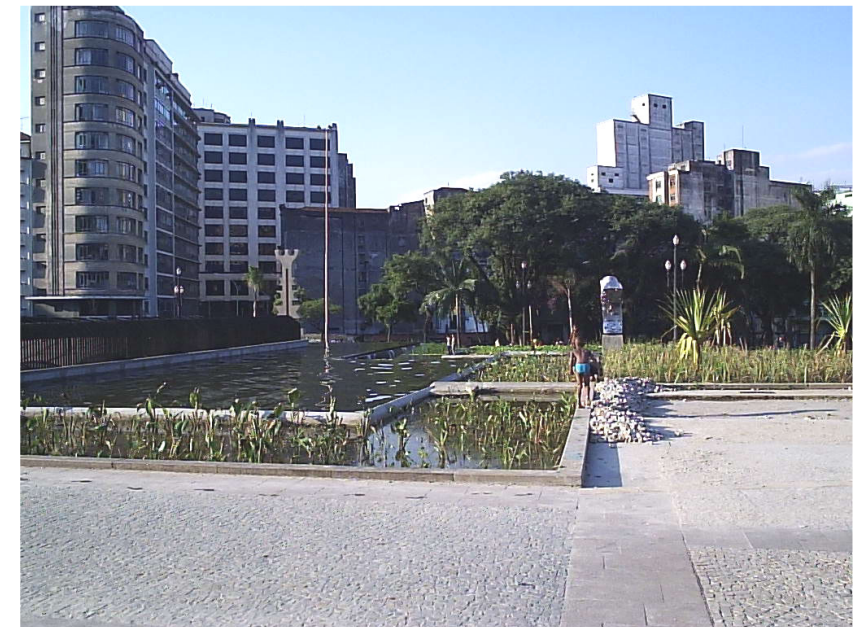

Figura 52 - Canteiros alagados, junto ao espelho d'água. Observar, ao fundo, trecho com piso inacabado.

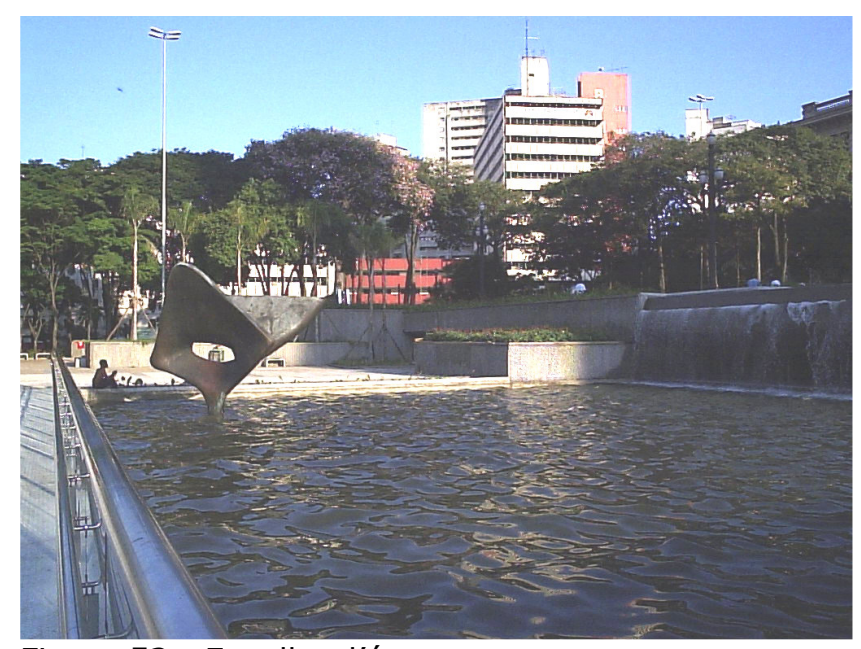

Figura 53 - Espelho d'água.

"Condor", escultura de Bruno Giorgi. 
Junto à Rua Anita Garibaldi, no início do eixo leste-oeste, foi criada uma rampa com inclinação suave $(6,9 \%$, segundo projeto da EMURB), sinalizada com piso tátil nas mudanças de nível. Os corrimãos ali instalados atendem à Norma. Nessa rampa, como nas demais, faltou patamar plano de descanso, porque seu desnível é de $1,85 \mathrm{~m}$, segundo a EMURB.

A forma, como as rampas foram projetadas, possibilita às PCDs utilizar os mesmos espaços, para atravessar a Praça, que as demais pessoas. Nesse trecho, antes da reforma, existiam floreiras altas que impediam esse fluxo.

As escadas junto à Rua Anita Garibaldi, no sentido norte-sul, não possuem rampas em suas laterais, porém a praça oferece alternativa de rota acessível no mesmo sentido, mais a oeste. Essas escadas estão sinalizadas com piso tátil de alerta, entretanto não possuem corrimãos.

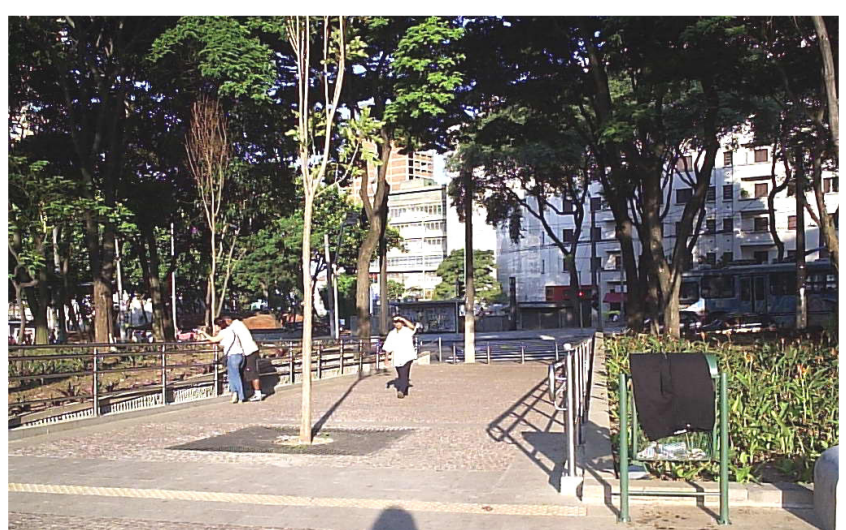

Figura 54 - Rampa de acesso ao eixo leste-oeste, junto à Rua Anita Garibaldi.

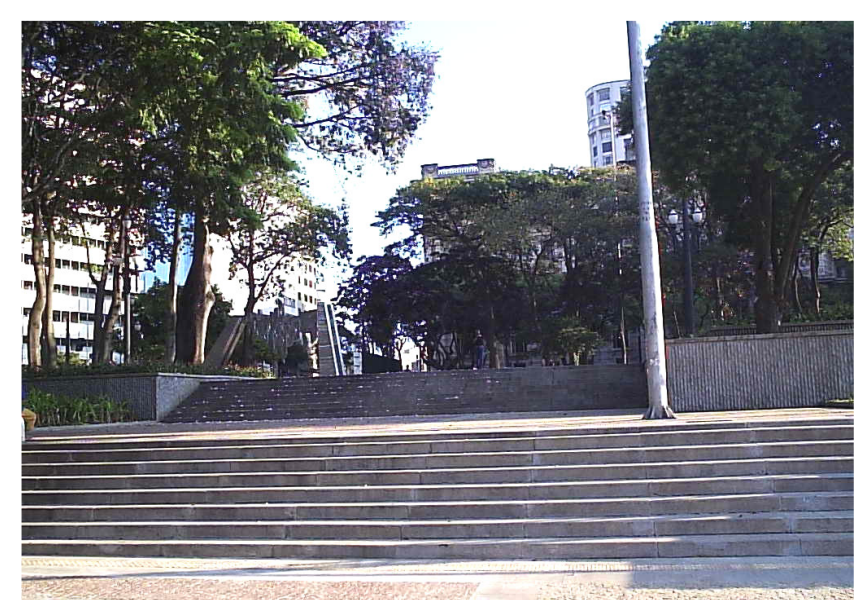

Figura 55 - Escadaria no eixo norte-sul, próximo à Rua Anita Garibaldi. 
As calçadas tiveram os pisos reformados. As travessias, no entorno da Praça, foram demarcadas e tiveram barreiras colocadas para impedir a passagem fora da faixa de pedestres. Como por exemplo, a Rua Anita Garibaldi.

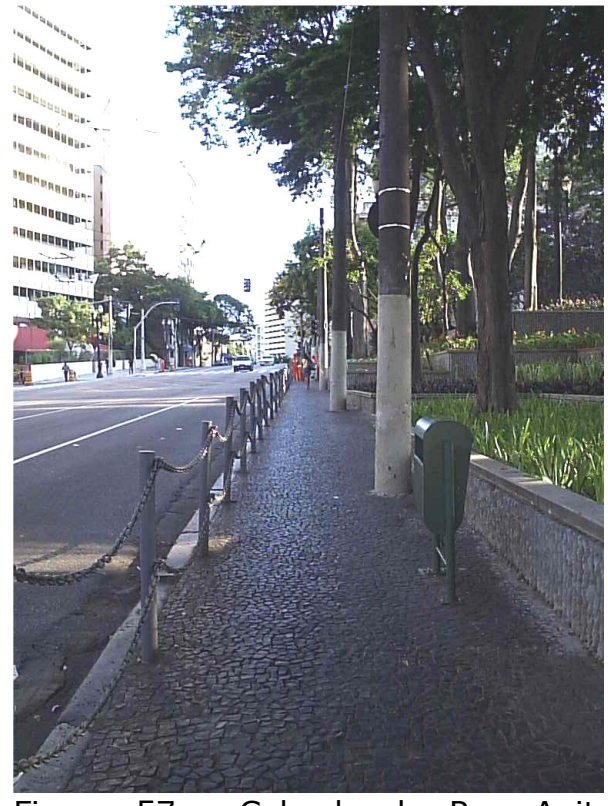

Figura 57 - Calçada da Rua Anita Garibaldi, junto à Praça, sentido sul. Observar barreiras.

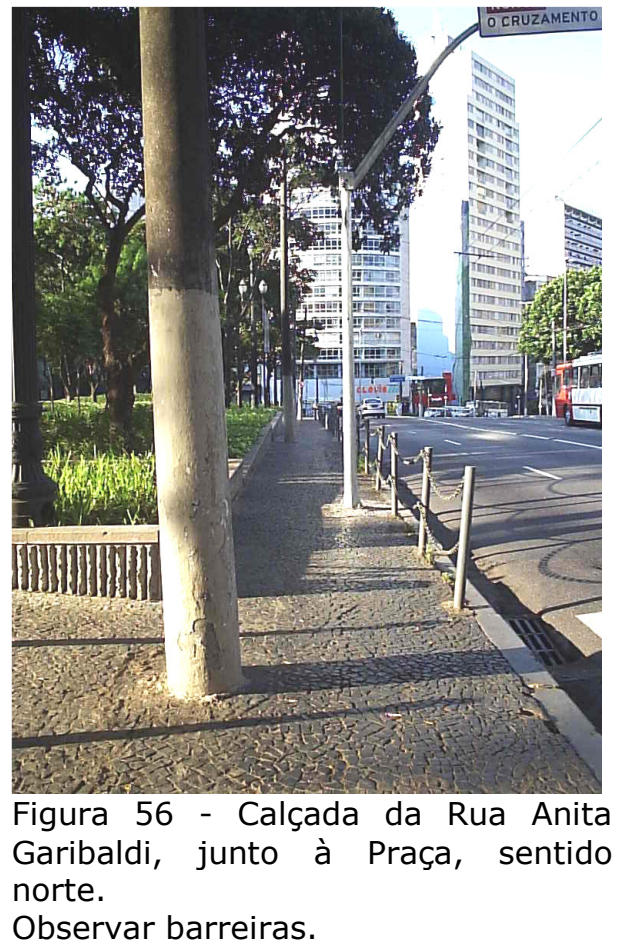

Observar barreiras. 
As faixas de pedestre nas, travessias da Rua Anita Garibaldi, são largas e bem demarcadas. Existe rebaixamento de guias com rampas pré-moldadas de concreto e não foi observada a existência de semáforos sonoros para o auxílio de pessoas com deficiência visual. Nesse caso, como o fluxo de pessoas é grande, em função da proximidade com a estação do Metrô, pode ser considerado número suficiente $^{17}$ para a necessidade da implantação de dispositivos sonoros nos semáforos.

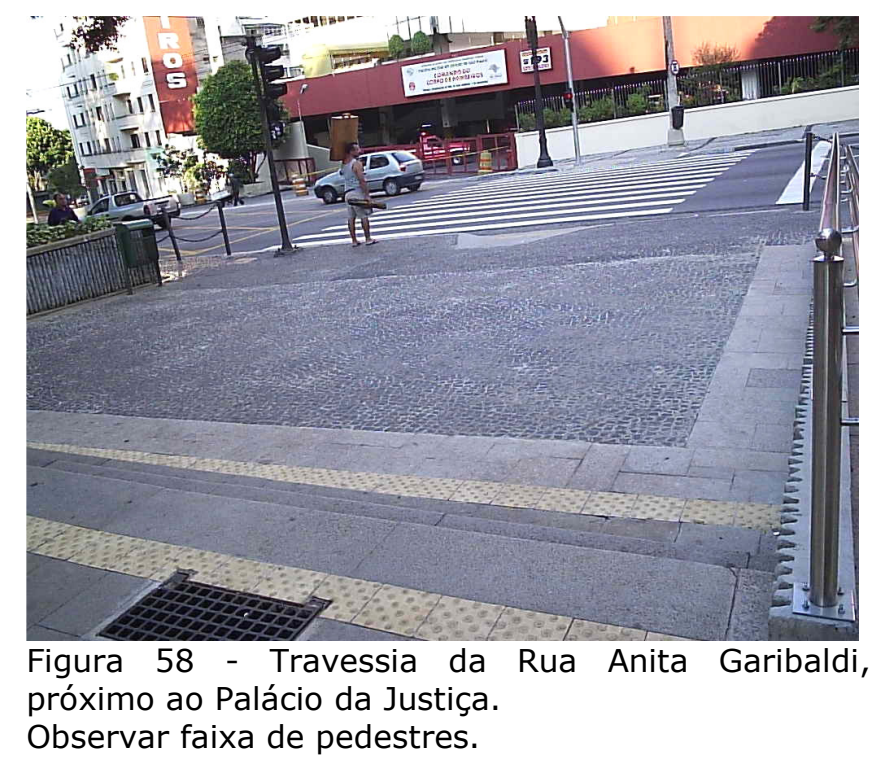

17 Segundo a NBR9050/2004, semáforos instalados em "vias públicas com grande volume de tráfego ou concentração de passagem de pessoas com deficiência visual devem estar equipados com mecanismos que emitam um sinal sonoro". 


\section{Considerações finais sobre a reforma da Praça da Sé}

Na época em que foi projetada, a Praça da Sé fazia parte de um contexto em que a acessibilidade não era uma preocupação consolidada na prática de projeto. Da década de 70 até hoje, houve uma série de avanços e conquistas em relação à acessibilidade.

No centro da Cidade de São Paulo, a Praça da Sé é um dos vértices de toda uma área destinada a pedestres, os chamados "calçadões". Porque o Centro foi tão cedo transformado em área para pedestres, a Praça é a maior e mais antiga com possibilidades de ser transformada em área de circulação de PCDs. Por isso, como cadeirante, é possível circular ainda hoje entre as Praças Ramos de Azevedo, Sé e São Bento.

O Centro da cidade de São Paulo, desde a década de 70, permite a acessibilidade, não porque, na época, tivessem a conscientização sobre essa necessidade, mas porque os "calçadões" precisavam ser acessíveis aos veículos de transporte de valores ou de segurança, atendendo as necessidades logísticas do comércio local.

A Praça da Sé, nos anos 70, poderia estar integrada à condição de acessibilidade dos "calçadões" adjacentes, no entanto o uso de 
escadarias, tão utilizado como elemento plástico na época, não oferecia outras opções que não fossem os degraus.

As praças do Metrô: Ana Rosa, Santa Cecília e Liberdade, também não fugiram à regra. Porém, mesmo que elas não sejam parte de um conjunto de espaços livres para pedestres, como a Praça da Sé, nem por isso deixam de ter a obrigação de serem espaços universalmente acessíveis, pois são locais de uso público, projetados por arquitetos e sob responsabilidade do Poder Público.

Os projetos de praças de Lawrence Halprin, citados por Bartalini (1988), como fontes de inspiração para as formas da Praça da Sé, assim como em outros projetos paisagísticos internacionais, da mesma época, não eram acessíveis e sugeriam tal déficit à versão brasileira, mas nem nos EUA, onde a questão da inclusão sempre esteve mais avançada, esse aspecto também não fora atendido.

Atualmente, a falta de manutenção adequada, nos "calçadões" do Centro da Cidade de São Paulo, causa buracos no piso, trepidações em cadeiras de rodas e carrinhos de bebês, os quais necessitam de desviar-se de suas rotas, constantemente. 
Após a reforma, a Praça da Sé passou a ser acessível. Soluções de projeto foram aplicadas, seguindo o desenho e as especificações originais da Praça, os quais procuram atender aos visitantes de forma igualitária, sem criar espaços demarcados para as pessoas com deficiência, evitando uso estigmatizado.

Na Cidade de São Paulo é muito comum encontrar-se diversas áreas com pequenas rampas, as quais foram implantadas para cadeirantes, à margem de atrações e percursos, impedindo que essas pessoas usufruam das mesmas oportunidades e espaços, que as demais pessoas.

Na Praça da Sé, essa necessidade foi transformada implantação grandes rampas, as quais são largas e atravessam a Praça, atendendo ao público em geral, e não apenas a cadeirantes.

As transposições do fosso do Metrô e do espelho d'água criaram novas possibilidades de circulação e apreensão do espaço, pois as plataformas, em nível, permitiram novos ângulos de visão. Os corrimãos e os guarda-corpos, corretamente instalados nas plataformas, não causam problemas às PCDs. 
As entradas reativadas do Metrô contribuíram para demarcar a nova circulação no local.

Embora a reforma da Praça tenha evoluído bastante nas questões da inclusão, o acesso ao Metrô (até a data da última visita), ainda não era possível aos cadeirantes, pois, do mezanino da estação do Metrô, até as plataformas de embarque e desembarque, não haviam rampas ou elevadores para possibilitar esse trajeto. Segundo a EMURB, um elevador seria implantado ali, para solucionar esse problema.

Com a eliminação de algumas jardineiras e o rebaixamento de outras, a visualização da Praça acontece de forma mais ampla, permitindo melhor orientação e percepção do espaço. Essa questão é muito importante para melhorar a sensação de segurança.

As calçadas que contornam a Praça atendem aos parâmetros do Programa Passeio Livre, da Prefeitura da Cidade de São Paulo.

As travessias possuem rebaixamentos de guias e faixas de pedestres bem sinalizadas, todavia não foi observada a implantação de semáforos que emitam sinal sonoro, os quais são utilizados nas travessias para orientar pessoas com deficiência visual. Segundo a 
NBR9050/2004, semáforos instalados em "vias públicas com grande volume de tráfego ou concentração de passagem de pessoas com deficiência visual devem estar equipados com mecanismos que emitam um sinal sonoro". Como o fluxo de pessoas na Praça da Sé é intenso, esse fato pode ser considerado suficiente para sua instalação.

Quanto ao percurso interno da Praça, os canteiros alagados e as floreiras, junto ao espelho d'água, afastaram o contato direto com a água, entretanto existem exemplos de outros projetos em que o contato é possível, propiciando outras experiências sensoriais.

Figura 59 - Parque Oizumi Ryokuchi, Osaka - Japão. Cadeirante com deficiência visual tocando o lago. Disponível em:

$<$ http://www.design.ncsu.edu/cud/projserv_ps/projects

No Parque Oizumi Ryokuchi, Osaka - Japão, por exemplo, todos psexemplars.htm > Acesso em 09/2007.

podem passar pelas mesmas experiências sensoriais ao longo dos percursos. Lá, os tanques de água foram projetados de tal forma que as cadeiras de rodas podem se aproximar e os cadeirantes tocar o líquido.

Conforme a EMURB, a água dos tanques da Praça da Sé não deveria ser tocada porque não teve tratamento adequado para isso. Entretanto, seria importante que melhorias fossem feitas para mudar esse quadro, possibilitando também essa experiência sensorial, dentro da Praça. 
A evolução social no trato da inclusão de PCDs fica evidenciada na reforma da Praça da Sé, pois atendeu à maioria dos requisitos necessários, segundo a Norma e legislações, de forma ampla e elegante, acolhendo não apenas essas exigências, mas também propiciando, desde a concepção do projeto, o conceito de inclusão social. 


\section{Estudo de caso - Calçadas}

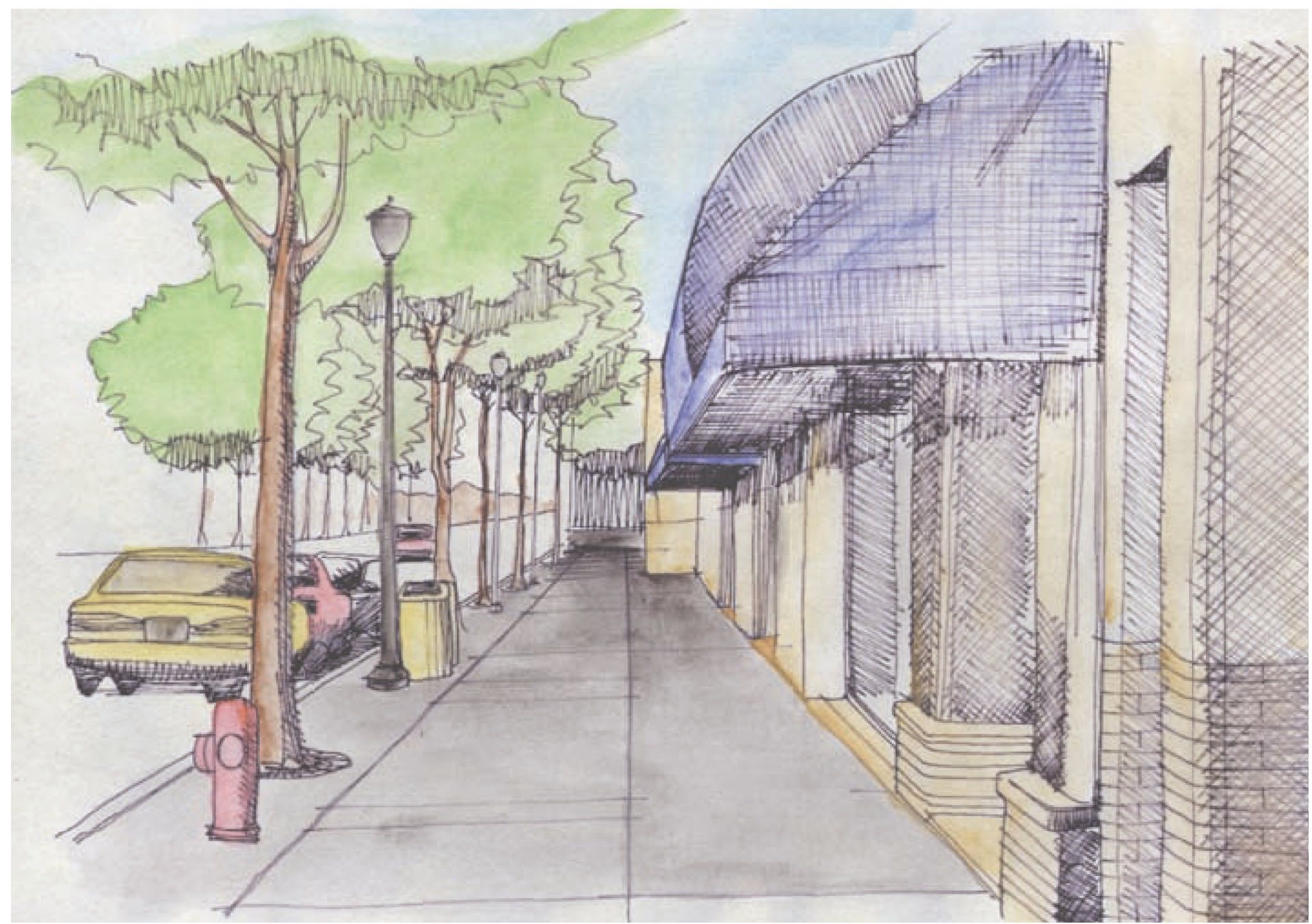

Figura 60 - Imagem: Cartilha Passeio Livre. Disponível em: http://ww2.prefeitura.sp.gov.br/passeiolivre/index.asp 


\section{Apresentação - Justificativa da escolha}

A calçada é parte fundamental do sistema de espaços livres públicos. Nela se dá a circulação do pedestre, o que segundo Gold (2003) representa $30 \%$ dos deslocamentos nas cidades.

O direito de ir e vir é garantido pela Constituição Brasileira, todavia, este direito é desrespeitado no que se refere às calçadas, pois suas condições são precárias, e muitas vezes impedem a circulação por elas, especialmente no caso de idosos e PCDs.

A falta de condições mínimas do passeio público faz com que se crie o hábito e a cultura de circular pelo leito carroçável, criando o conflito de fluxos entre veículos e pedestres. De acordo com Gold (2003), 50\% das vítimas fatais nos acidentes de trânsito correspondem aos casos de atropelamentos.

O conjunto de calçadas constitui parte fundamental do sistema de transportes, é por elas que se tem acesso ao transporte público e aos edifícios. Para PCDs, as condições das calçadas são tão limitadoras, que ou utilizam automóveis, ou são forçados a permanecer em casa, na maioria das vezes. 
De acordo com Yázigi (2000):

$\mathrm{Na}$ calçada realiza-se o universal, o encontro do outro, do diferente cujo ser dá sentido à democracia [...] Fora dos espaços fechados e de nossos iguais, dos valores de grupo, na rua, somos submetidos ao encontro do lugar e da existência que realmente realizam nosso sentido de coletivo ou, na pior das hipóteses, funcionam como cartilha. Nela, sem identidade, somos frágeis, por isso merecedores de uma ordem que nos proteja. Mas sair pela porta da frente transforma em risco o que poderia ser uma reinvenção da flanação, fazendo da cidade o lugar do medo, ao invés de tradicional lugar de encontro e trocas.

As calçadas escolhidas para analise sofreram reformas promovidas ou orientadas pela Prefeitura de São Paulo. Como tal, passaram por projetistas que têm a obrigação de incorporarem as questões de acessibilidade para PCDs, garantindo direitos iguais de circulação e cidadania a toda população. 


\section{Metodologia do estudo de caso - Calçadas}

As calçadas apresentadas, neste estudo de caso, foram delimitadas em função da extensão das reformas que sofreram para a atual requalificação.

Os levantamentos de dados consistiram na análise bibliográfica de trabalhos sobre calçadas, especialmente em relação ao Programa Passeio Livre.

Consultas na Internet propiciaram informações a respeito das manifestações por parte dos munícipes próximos às intervenções e às condições em que essas obras aconteceram.

O contato com os gestores públicos deu-se basicamente com a Prefeitura de São Paulo, a qual forneceu material e dados sobre o Programa Passeio Livre, além de informações sobre peculiaridades de algumas das ruas comerciais, tais como as Ruas João Cachoeira e Oscar Freire.

Consulta à $E M U R B$ foi importante para a obtenção de dados sobre a Avenida Rebouças. 
O Metrô, responsável pela obra de reforma da Rua dos Pinheiros, não pôde fornecer dados suficientes, pois um acidente ocorrido nas obras, da Linha 4, impediu a divulgação de mais informações. Para prosseguimento do presente estudo, consultou-se então, a Prefeitura de São Paulo.

Foram realizadas visitas técnicas na Avenida Rebouças, nas Ruas dos Pinheiros e João Cachoeira, resultando em relatório fotográfico a ser apresentado e detalhado ao longo deste capítulo.

As calçadas das Ruas Oscar Freire, Augusta, Avanhandava e do Projeto Brooklin Acessível ${ }^{18}$ também foram visitadas, para conhecimento, comparação e análise de suas condições atuais. Esses locais foram fotografados, mas não foram feitos relatórios.

As calçadas do entorno do Hospital das Clínicas e do próprio conjunto foram estudadas em disciplina de pós-graduação (AUT-5805 Avaliação Pós Ocupação), que resultou na análise e relatório final de disciplina, os quais contribuíram com as informações para essa etapa da pesquisa.

18 ORNSTEIN, Sheila Walbe; LOPES, Maria Elisabete; CAMBIAGHI, Silvana Serafino. Brooklin acessível. São Paulo: Faculdade de Arquitetura e Urbanismo da Universidade de São Paulo, 2001. (mimeo/ caderno de projetos executivos).

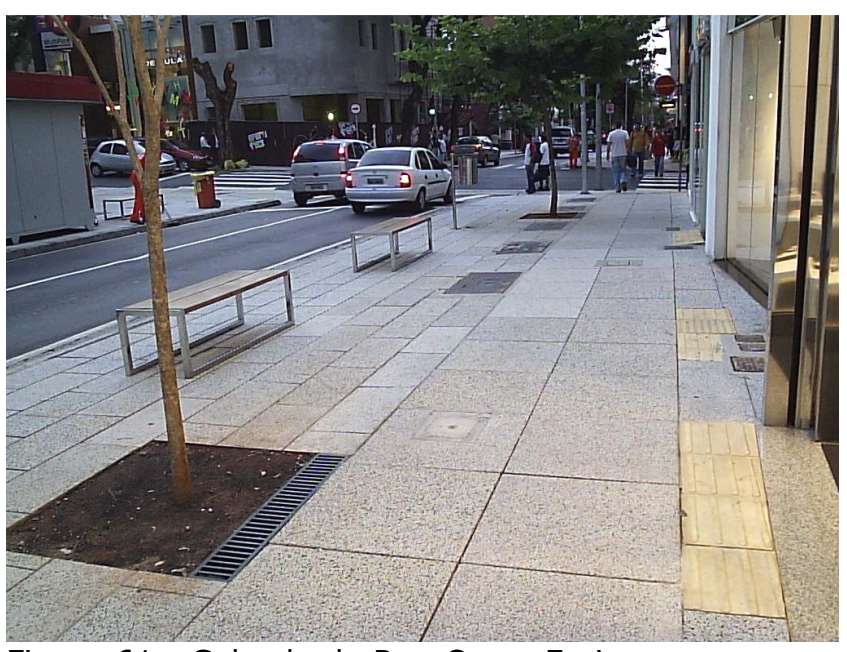

Figura 61 - Calçada da Rua Oscar Freire.

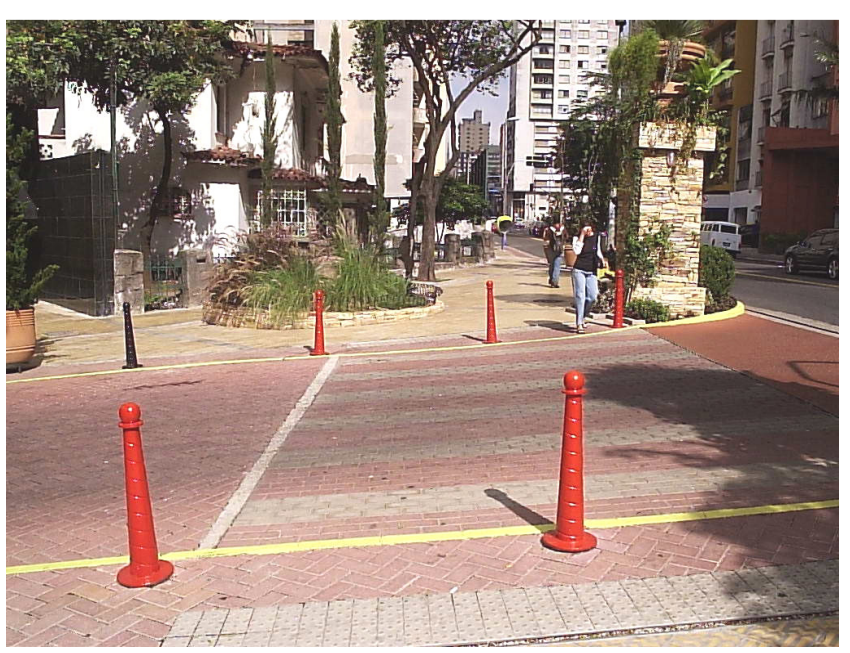

Figura 62 - Travessia na Rua Avanhandava. 
Para os roteiros fotográficos, foram percorridos ambos os lados das vias, nos trechos reformados.

O relatório das calçadas foi encaminhado aos respectivos órgãos públicos, para conhecimento e como forma de retribuição à atenção dispensada. 


\section{Calçadas - definições}

Segundo o Código de Trânsito Brasileiro (CTB), também utilizado na legislação federal e municipal, calçada é a "parte da via, normalmente segregada e em nível diferente, não destinada à circulação de veículos, reservada ao trânsito de pedestres e, quando possível, à implantação de mobiliário urbano, sinalização, vegetação e outros fins."

De acordo com o mesmo documento, passeio público é a "parte da calçada ou da pista de rolamento, neste último caso, separada por pintura ou elemento físico separador, livre de interferências, destinada à circulação exclusiva de pedestres e, excepcionalmente, de ciclistas". 


\section{Apresentação do Programa Passeio Livre}

A Prefeitura de São Paulo, na gestão do Prefeito José Serra, criou o "Programa Passeio Livre", o qual visa tornar acessível o passeio público da cidade, resgatando o caráter social dos espaços públicos e melhorando a paisagem.

O projeto define que as calçadas sejam divididas em faixas de zoneamento, diferenciadas por cores e texturas. As calçadas, com até $2 \mathrm{~m}$ de largura, terão duas faixas e as calçadas com mais de $2 \mathrm{~m}$, terão três faixas. Segundo a Prefeitura, essas faixas serão caracterizadas basicamente por:

- Faixa de Serviço: é a faixa mais externa à calçada. As locações de postes, árvores, mobiliário urbano e rampas de acesso para veículos ou pedestres devem estar nessa faixa. 
- Faixa Livre: é a zona de circulação, situada na parte central da calçada, que deve ter largura mínima de 1,20m, e estar desobstruída em toda a sua extensão, a qual deve ser contínua e sem desníveis, tornando-se uma rota acessível ${ }^{19}$.

- Faixa de Acesso: é a faixa de apoio aos lotes. Nela permite-se que proprietários desses lotes possam colocar propagandas, mobiliário móvel e jardins.

Em casos onde a largura da calçada é inferior a 1,90m, a Prefeitura sede um técnico para avaliar a situação do passeio e auxiliar na obtenção de melhor alternativa para a criação de faixa de circulação contínua, que é a questão principal do projeto.

Os desníveis necessários para a entrada de veículos nos lotes devem ser feitos na faixa de serviço, priorizando a faixa livre para a circulação de pedestres.

\footnotetext{
19 Rota acessível - "trajeto contínuo, desobstruído e sinalizado que conecta os elementos e os espaços internos ou externos de um local e pode ser utilizado de forma autônoma e segura por todas as pessoas, inclusive aquelas com mobilidade reduzida, sendo que:

a) A rota acessível interna pode incorporar corredores, pisos, rampas, escadas, elevadores, entre outros;

b) A rota acessível externa pode incorporar estacionamentos, calçadas e guias rebaixadas, faixas de travessia de pedestres, rampas, entre outros." Decreto No. 45.904 , de 19 de maio de 2005
} 
As esquinas devem ser desobstruídas, por tratar-se de espaços de maior permanência. Mobiliários grandes, como bancas de jornal, por exemplo, devem estar no mínimo a $15 \mathrm{~m}$ do alinhamento da via transversal, enquanto que mobiliários menores como telefones públicos, por exemplo, devem estar a pelo menos $5 \mathrm{~m}$ do alinhamento da via transversal.

Pisos de orientação e de alerta para pessoas com deficiência visual, também chamados de "podotáteis", devem ser colocados nas calçadas. Esses devem ser utilizados nos seguintes casos:

- para indicar obstáculos suspensos, por exemplo, lixeiras fixas em portões;

- objetos com projeção no piso, maiores do que a dimensão de suas bases, por exemplo, "orelhões";

- para indicar o final das rampas, em calçadas, destinadas às pessoas com deficiência.

As faixas de orientação são utilizadas para guiar o sentido do fluxo, por exemplo, indicando o caminho em espaços muito amplos.

Em relação à vegetação, serão escolhidas de acordo com a dimensão e a largura das calçadas. Compete à Prefeitura plantar e 
fazer a manutenção das espécies, conforme a Lei 10.365 de 1987 e a Lei 13.646 de 2003.

Em ruas com pequeno fluxo de pedestres, as faixas de serviço e de acesso podem ser substituídas por faixas de ajardinamento (as chamadas faixas verdes). Para que isso aconteça, será necessário que o passeio tenha no mínimo $2 \mathrm{~m}$ de largura para ter uma delas. A calçada que tiver no mínimo 2,5m de largura, poderá receber as duas faixas verdes, mantendo pelo menos, $1,20 \mathrm{~m}$ de passeio livre.

As chamadas "calçadas verdes" não deverão ter arbustos que prejudiquem a visão e o caminho de pedestres. Não sendo permitido o uso de espécies que tenham espinhos.

De acordo com a Lei 13.646 de 2003, a vegetação utilizada em calçadas é responsabilidade da Prefeitura. As espécies devem ser características de Mata Atlântica, não podem ser tóxicas ou conter espinhos. Nessa lei, não há referência às questões de segurança e acessibilidade, como acontece no Decreto 45.904 de 2005, por exemplo, o qual trata sobre a padronização dos passeios públicos no município de São Paulo. A vegetação, segundo esse Decreto, deve ser elemento que cause riscos de acidentes ou interferência no caminho do pedestre. 
De acordo com a Norma Brasileira de Acessibilidade - NBR 9050/2004 -, a vegetação não deve ter galhos que possam causar acidentes. Esses galhos deverão estar no mínimo a 2,10m de altura do piso da calçada, quando estiver no percurso do pedestre, e as espécies utilizadas não podem danificar o piso do passeio público.

O manual intitulado "Passeio Livre" está disponível na Internet $<$ http://ww2.prefeitura.sp.gov.br/passeiolivre/index.asp> com todas as informações necessárias ao público, esclarecendo as formas de se construir e manter as calçadas, de acordo com o Decreto no. 45.904 de 2005.

Além das três faixas de circulação, o Programa determina os tipos de pavimentação permitidos pelo Decreto, a serem utilizados nas calçadas, descritos a baixo:

1. "concreto pré-moldado ou moldado 'in loco', com juntas ou em placas, acabamento desempenado, texturado ou estampado", desde que não causem vibrações que prejudiquem a circulação de cadeirantes;

2. bloco de concreto intertravado;

3. ladrilho hidráulico. 
Em situações "especiais", como calçadas contíguas a áreas de lazer, mediante aprovação da Prefeitura, serão permitidas a utilização de pisos de pedras naturais, ou mosaico português, desde que, em ambos os casos, não sejam na faixa livre e não haja instalação de infra-estrutura no subsolo. 


\section{Comentários gerais sobre o Programa Passeio Livre e as calçadas}

As calçadas, em frente aos lotes, são de responsabilidade dos proprietários desses imóveis, de acordo com as leis municipais da Cidade de São Paulo. Essa prática torna as calçadas da cidade em "colcha de retalhos". Aliada à falta de fiscalização da Prefeitura, as calçadas tornaram-se, em inúmeros casos, intransitáveis.

Seria necessário rever todo o sistema de calçadas da Cidade para obterem-se resultados significativos. Instituir três únicos tipos de pisos, para toda a cidade, limita as possibilidades de uso e não abrange todas as soluções necessárias.

As questões sociais e de formação urbanística estruturam o espaço de forma profunda e requerem propostas complexas. No entanto, uma fiscalização atuante, aliada às mudanças de legislação, campanhas e programas de conscientização, poderiam ser o ponto de partida para resolver o problema.

O trabalho desenvolvido pelo Programa Passeio Livre é

interessante por tratar-se da busca de melhores condições de sociabilidade e circulação na cidade de São Paulo, apesar de conter 
erros e acertos trata-se de um bom "passo" em prol das calçadas, as quais se encontram em situação lamentável.

Passeios adequados permitem trânsito com segurança, sem distinção ou privilégio.

Não apenas os idosos e pessoas com deficiência enfrentam dificuldades em circular. As pessoas, de modo geral, também têm dificuldades, podendo sofrer algum tipo de acidente num buraco de calçada, ou pior, quando se arriscam dividindo o espaço de circulação dos veículos, pois o leito carroçável, normalmente, está em melhor estado de conservação que as calçadas, pois é foco principal das atenções e investimentos.

A zona de manutenção, onde são instalados os postes e todos os equipamentos das vias, é alvo de constantes reparos, o que normalmente inviabiliza a circulação de pedestres durante a manutenção. Desse modo, a manutenção pode ocorrer sem interrupção do fluxo de pessoas, em função da separação de usos.

O incentivo à utilização de pisos intertravados pode ser interessante pelas facilidades de manutenção e pelo aspecto estético, porém a justificativa de que é permeável é questionável, porque a 
compactação do solo, durante a obra, inviabiliza a absorção. A execução do piso intertravado deve ser cuidadosa, pois caso contrário, saliências poderão causar acidentes e também gerar trepidações na circulação de cadeirantes.

As ruas comerciais, que procuraram à Prefeitura do Município de São Paulo e reformaram suas calçadas, aumentaram em 20\% suas vendas, em função da requalificação do espaço, segundo dados da Prefeitura.

Todas as calçadas analisadas, nesta dissertação, obtiveram enorme salto qualitativo para a circulação e a acessibilidade. As soluções adotadas permitiram a circulação de PCDs, atendendo não apenas aspectos da legislação, mas também às questões de qualidade nos espaços. 


\section{Calçadas da Avenida Rebouças}

\section{Justificativa da escolha}

A Avenida Rebouças é uma importante via de fluxo da cidade de São Paulo. Faz a ligação entre a área da Avenida Paulista, Dr. Arnaldo e Rua da Consolação com a Avenida Marginal do Rio Pinheiros.

Segundo a Companhia de Engenharia de Tráfego (CET), diariamente, nos horários de pico, chegam a circular cerca de 5.000 veículos por hora na Avenida Rebouças.

O Hospital das Clínicas, localizado naquela avenida, atrai 40 mil pessoas diariamente ${ }^{20}$ e gera fluxo de quase 5.000 pedestres, por dia, na passarela sobre a Avenida.

Dentro desse contexto, as calçadas da Avenida Rebouças passaram por extensa reforma, em todo seu percurso, trazendo transformações significativas tanto na paisagem como na acessibilidade.

${ }^{20}$ Disponível em <http://www.hcnet.usp.br/>. Acesso em out./2006. 


\section{Apresentação da reforma das calçadas da Avenida Rebouças}

A reforma da Avenida Rebouças teve início na gestão da Prefeita Marta Suplicy. O projeto e a execução foram realizados pela EMURB. As calçadas foram reformadas e padronizadas, em 3,8 quilômetros de extensão, segundo a Prefeitura (se considerada desde à Ponte Eusébio Matoso - como Avenida Eusébio Matoso - até à região do Hospital das Clínicas), com piso de ladrilho hidráulico e a fiação aérea toda enterrada.

As obras de requalificação do passeio fazem parte do Termo de Compensação Ambiental (TCA), decorrentes da construção dos túneis Rebouças e Max Feffer, de acordo com a Associação Rebouças Viva.

Durante a fase do projeto e implementação das obras, muitos foram os protestos dos comerciantes, moradores e associações, contra a implantação do corredor de ônibus. A expectativa era a de que provocaria prejuízos na paisagem, semelhantes aos verificados na Avenida Santo Amaro e problemas no faturamento dos estabelecimentos locais.

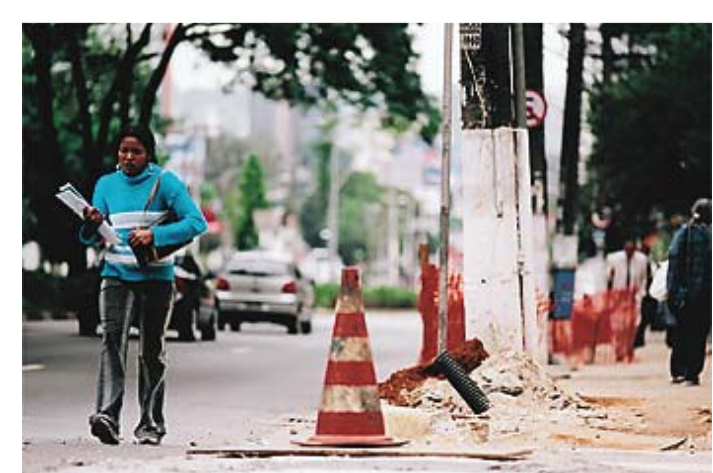

Figura 63 - Foto: Heudes Regis

"Cones e entulho em quase toda a Rebouças: segundo a prefeitura, a situação será resolvida no fim de dezembro"

http://veja.abril.com.br/vejasp/171104/cid ade.html

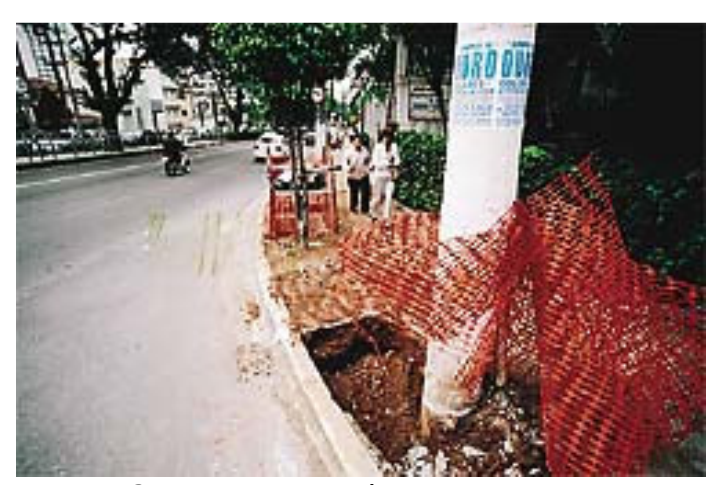

Figura 64 - Foto: Heudes Regis

"Perto do Hospital das Clínicas: um dos piores trechos"

http://veja.abril.com.br/vejasp/171104/cid ade.html 
A fase de obra foi extensa, chegando à gestão seguinte (Prefeito José Serra), e durante esse período os pedestres foram bastante prejudicados por não haver planos de rotas seguras e acessíveis ou alternativas às pessoas que ali circulavam. 


\section{Avenida Rebouças - roteiro fotográfico}

A seguir, as fotos apresentadas foram tiradas, pela autora do presente trabalho, no dia 7 de setembro de 2006.

$\mathrm{Na}$ alça de acesso que liga a Avenida Marginal do Rio Pinheiros à Avenida Eusébio Matoso, observou-se que a sinalização viária de travessia de pedestres está bem conservada.

O edifício do Banco Unibanco, situado na esquina das vias citadas acima, utiliza a calçada como via de acesso ao estacionamento, dificultando a circulação de pedestres (na foto superior, a calçada estampada funciona como circulação de veículos, e não de pedestres).

Como se vê na foto inferior, em um dos lados da via, a rampa na calçada foi implantada corretamente, dentro dos parâmetros da legislação e da Norma, porém, do outro lado dessa via, onde deveria haver outra rampa, que permitisse a subida da calçada por cadeirantes, carrinhos de bebê, etc., encontra-se a entrada do estacionamento, e dessa forma impede o fluxo contínuo do passeio, criando degraus para os pedestres e rebaixamento contínuo para os automóveis.

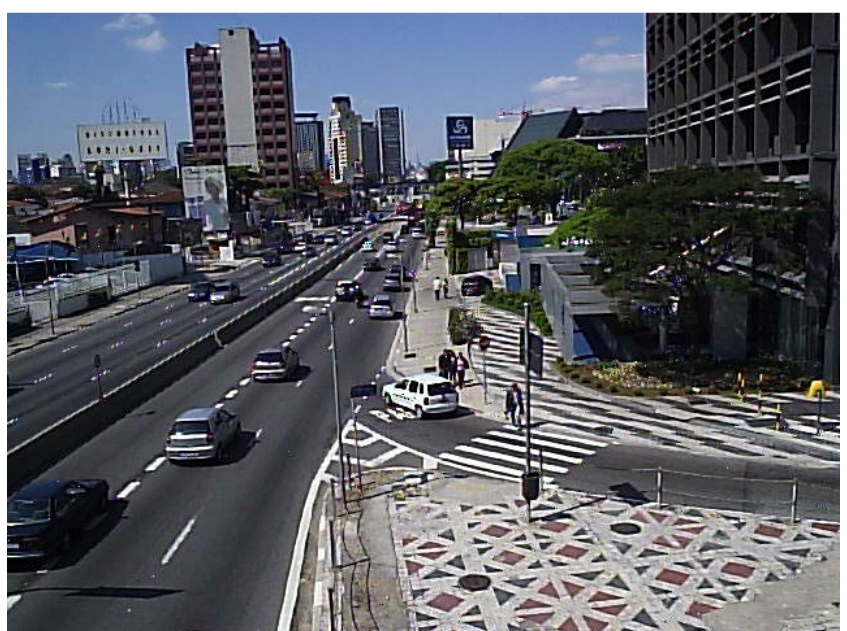

Figura 65 - Calçada da Avenida Eusébio Matoso em direção ao centro. À direita, alça de acesso da Avenida Marginal do Rio Pinheiros.

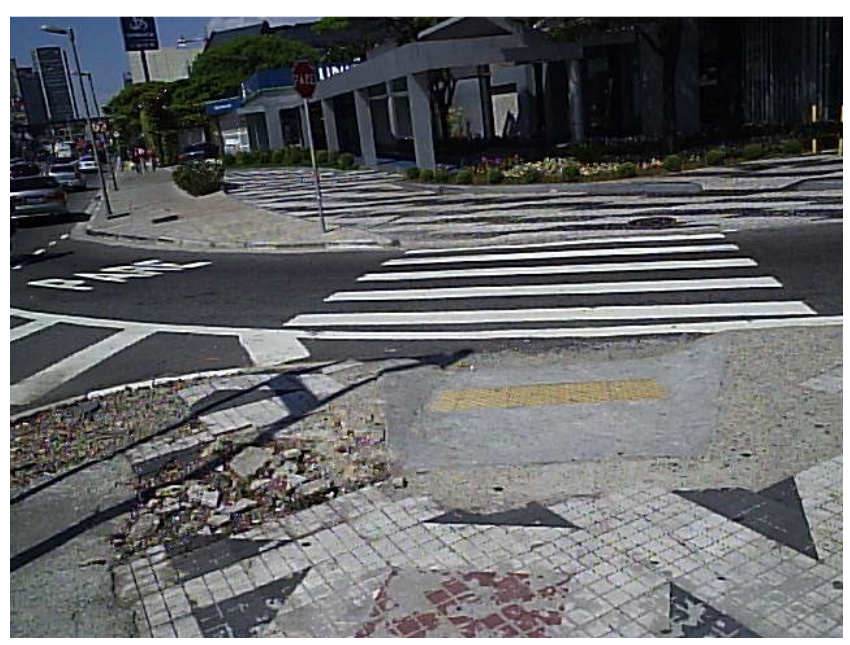

Figura 66 - Detalhe da travessia da alça de acesso da Avenida Marginal do Rio Pinheiros. 
A entrada do Banco Itaú, na Av. Rebouças, tem a transição do passeio, por veículos, de forma segura e sinalizada. O pedestre não encontra desníveis e é possível aguardar de forma confortável, a passagem de automóveis. Faltou, antes e depois da faixa de pedestres, a colocação de piso tátil de alerta para orientação de pessoas com deficiência visual, chamando atenção para esse cruzamento de fluxos.

A largura do passeio ao longo da Avenida Rebouças é variável. As dimensões variam de aproximadamente $1,20 \mathrm{~m}$ (próximo ao cruzamento da Av. Rebouças com a Av. Brigadeiro Faria Lima, sentido bairro) a $4 \mathrm{~m}$, e atendem ao fluxo local de pedestres.

Embora a reforma tenha sido feita antes do lançamento do Programa Passeio Livre, as faixas de circulação atendem aos parâmetros e permitem o fluxo sem "zigue-zagues" e isso ocorre em quase toda a extensão.

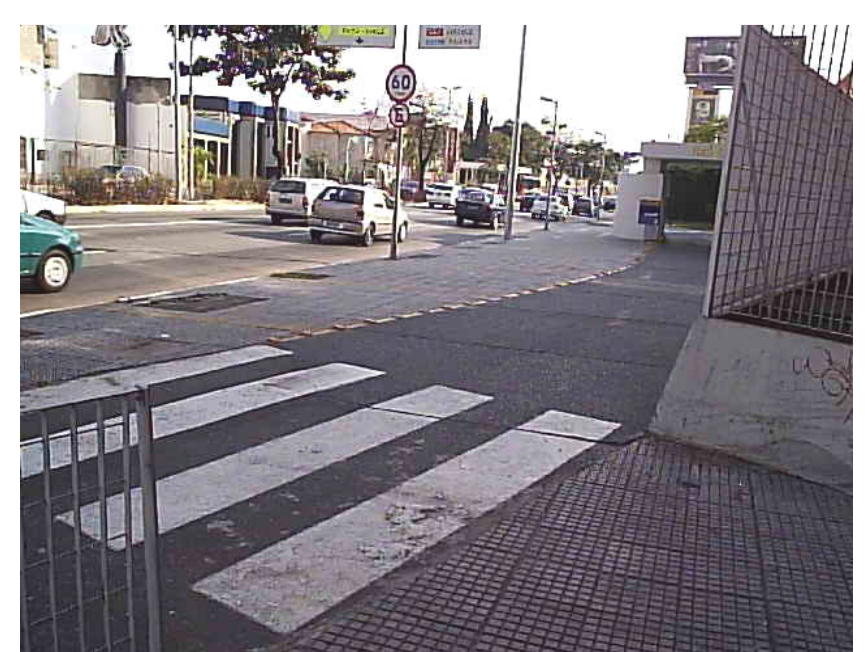

Figura 67 - Calçada do Banco Itaú.

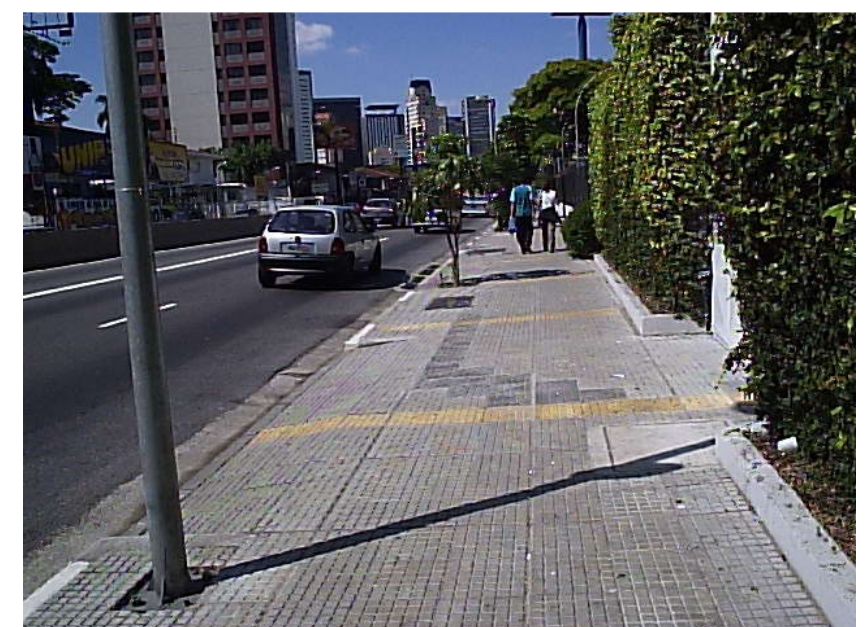

Figura 68 - Passeio público padronizado e percurso livre de obstáculos. 
Ao longo de todo o percurso, foram encontradas rampas não perpendiculares às faixas de pedestre. Essa questão é importante, pois a rampa orienta cadeirantes e pessoas com deficiência visual na direção do percurso, ou seja, se as rampas não estiverem perpendiculares às faixas, corre-se o risco de nortearem pedestres para a direção do fluxo de veículos.

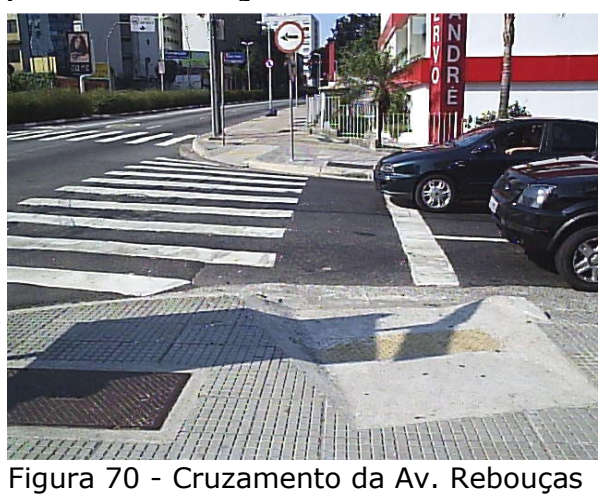
com a Rua João Moura.

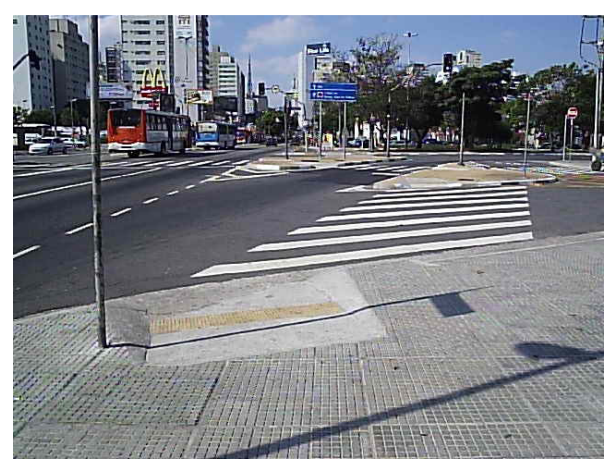

Figura 74 - Cruzamento da Av. Rebouças com Av. Brasil.

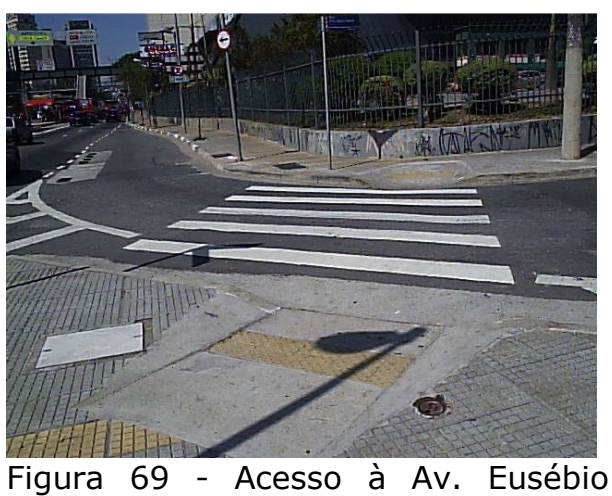

esquina com o Shopping Center Eldorado.

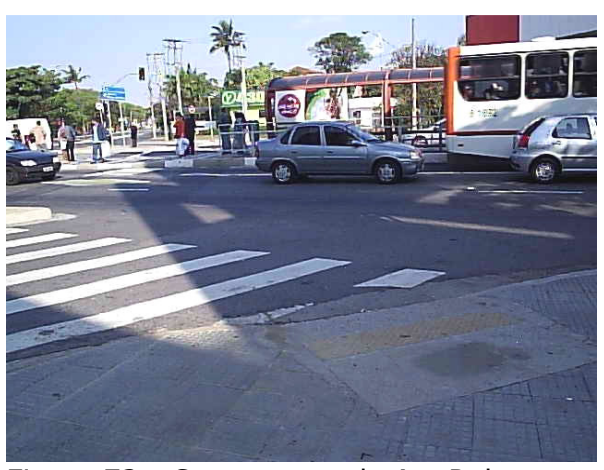

Figura 72 - Cruzamento da Av. Rebouças com Rua Henrique Schaumann.

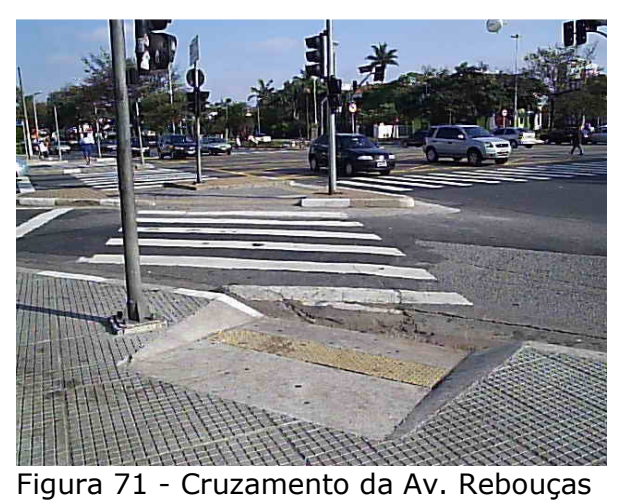
com Av. Brasil.

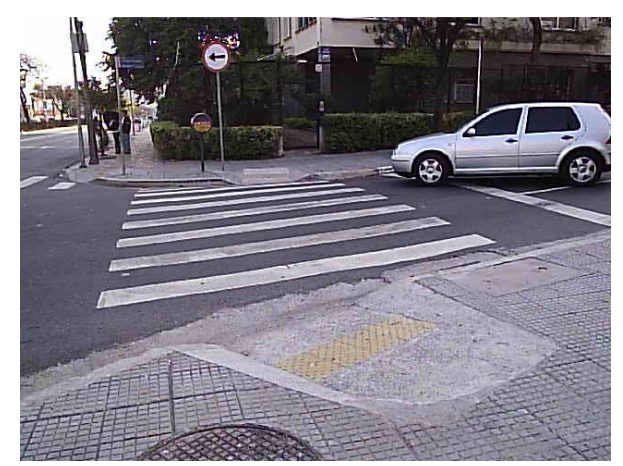

Figura 73 - Cruzamento da Av. Rebouças com Rua Joaquim Antunes. 
A foto superior é um exemplo de travessia correta e segura (Av. Rebouças com a Av. Eusébio Matoso). O estado de conservação das rampas, do passeio e da via é bom. A colocação das rampas está perpendicular à faixa de pedestres e o piso tátil foi utilizado corretamente.

A implantação das rampas nas calçadas foi executada, na maior parte dos casos, com muito cuidado, resultando em encontros perfeitos entre a pista e o passeio. Em outras ruas da Cidade o que se vê, muitas vezes, são casos de saliências no asfalto, dificultando a utilização das rampas.

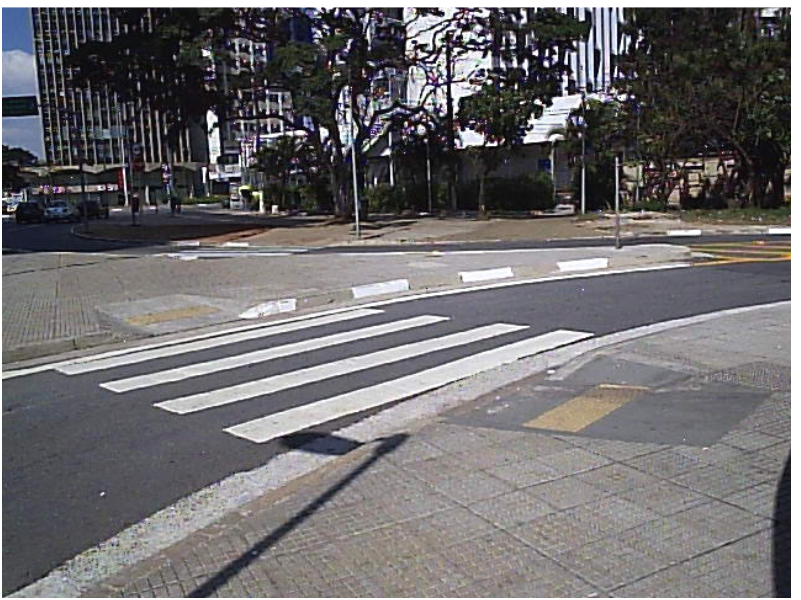

Figura 75 - Acesso da Av. Rebouças com a Av. Eusébio Matoso

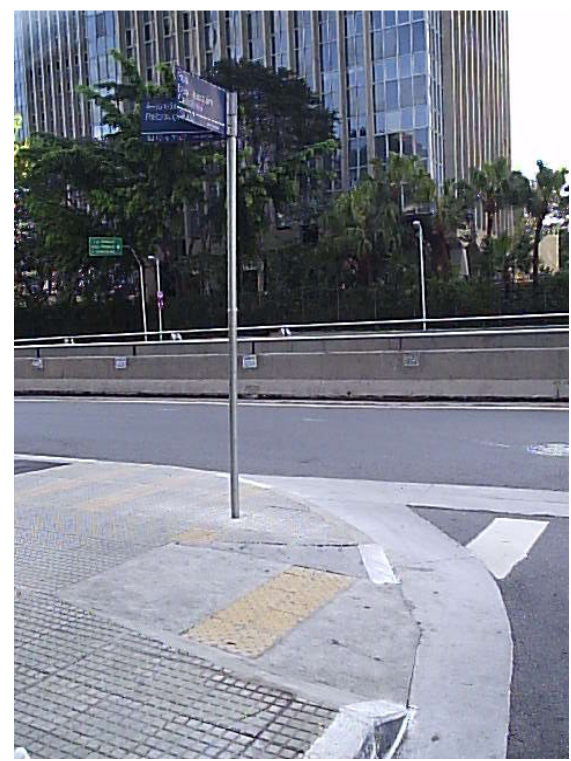

Figura 76 - Rampa bem executada na esquina da Rua Des. Joaquim Celidonio. 
Em algumas travessias, junto à faixa de pedestres, faltou a colocação de rampas próximas às esquinas, e rebaixos na ilha central para a travessia de cadeirantes.

O cruzamento da Av. Rebouças e Av. Pedroso de Moraes é um bom exemplo de desenho de travessia acessível e segura, transpassando o canteiro central. As rampas estão bem posicionadas em relação à faixa de pedestres. A ilha central facilita a travessia, propiciando local seguro para a permanência, e distâncias menores para o cruzamento da via.

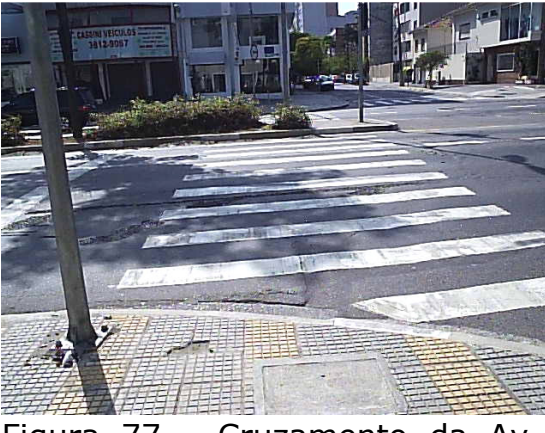

Figura 77 - Cruzamento da Av. Rebouças com a Rua João Moura.

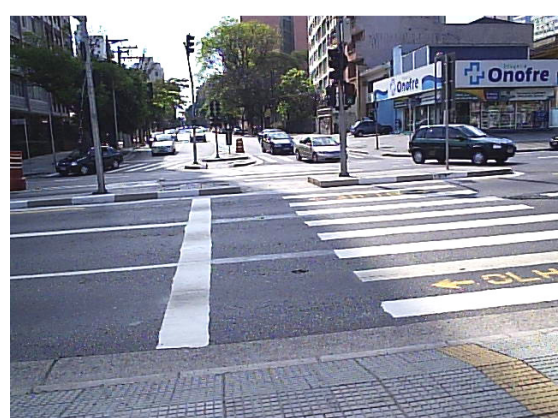

Figura 78 - Cruzamento da Av. Rebouças com a Av. Pedroso de Mnraec.

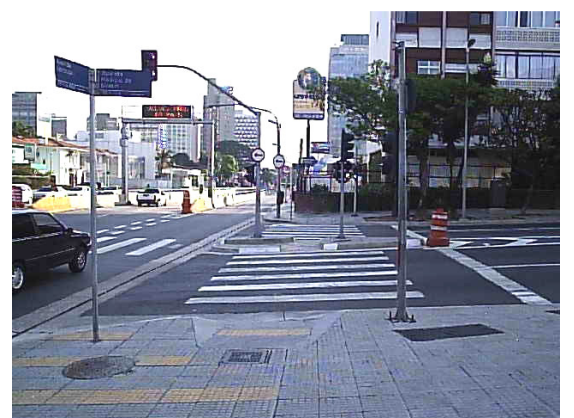

Figura 79 - Cruzamento da Av. Rebouças com a Av. Pedroso de Moraes. 
Apesar de a fiação aérea ter sido enterra e muitos postes eliminados das calçadas, restou "posteamento" excessivo, por causa da iluminação e da sinalização viária e, por isso, as esquinas apresentam problemas de permanência e circulação de pedestres.

A publicidade irregular também dificulta a circulação. Na foto ao lado, há vegetação inadequada do lote, com espinhos, podendo causar acidentes.

Os telefones públicos, chamados "orelhões", possuem versões com aparelhos mais baixos, voltados para cadeirantes e pessoas com baixa estatura.

Para os "orelhões", não foi observada a utilização de piso tátil de alerta. Essa sinalização é importante para orientar pessoas com deficiência visual, quanto à existência do equipamento, pois como sua base não corresponde ao volume suspenso, não será detectado pela bengala, podendo causar acidentes. A bengala detecta apenas volumes que estejam a até $0,60 \mathrm{~m}$ do piso, os volumes dos "orelhões" estão acima dessa medida.

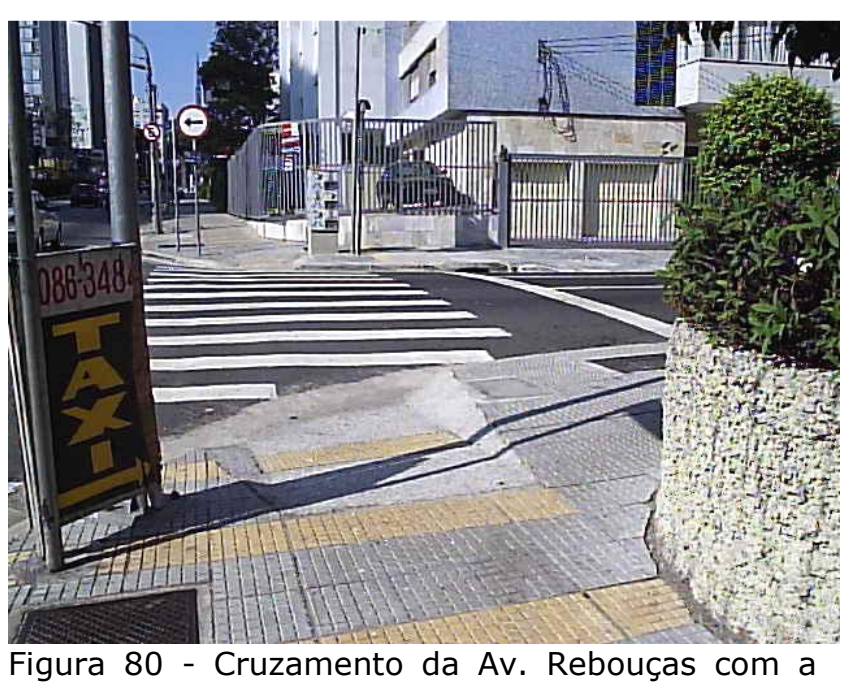

Figura 80 - Cruzamento da Av. Rebouças com a Rua João Moura.

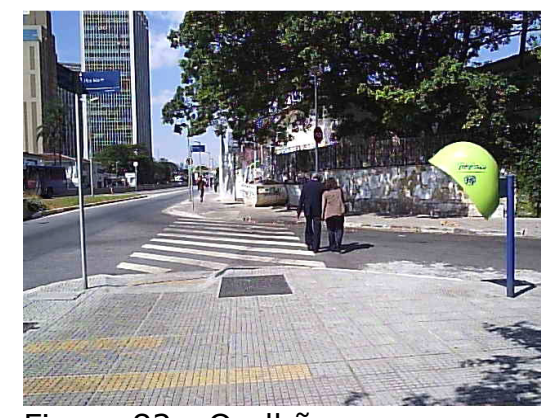

Figura 82 - Orelhão, cruzamento da Rua Marte com Av. Eusébio Matoso.

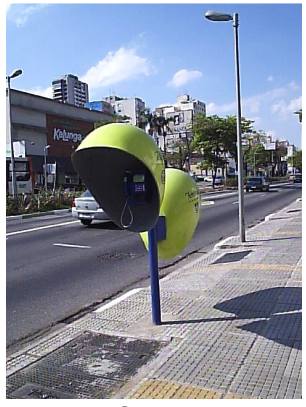

Figura 81 Orelhão na calçada da Av. Rebouças. 

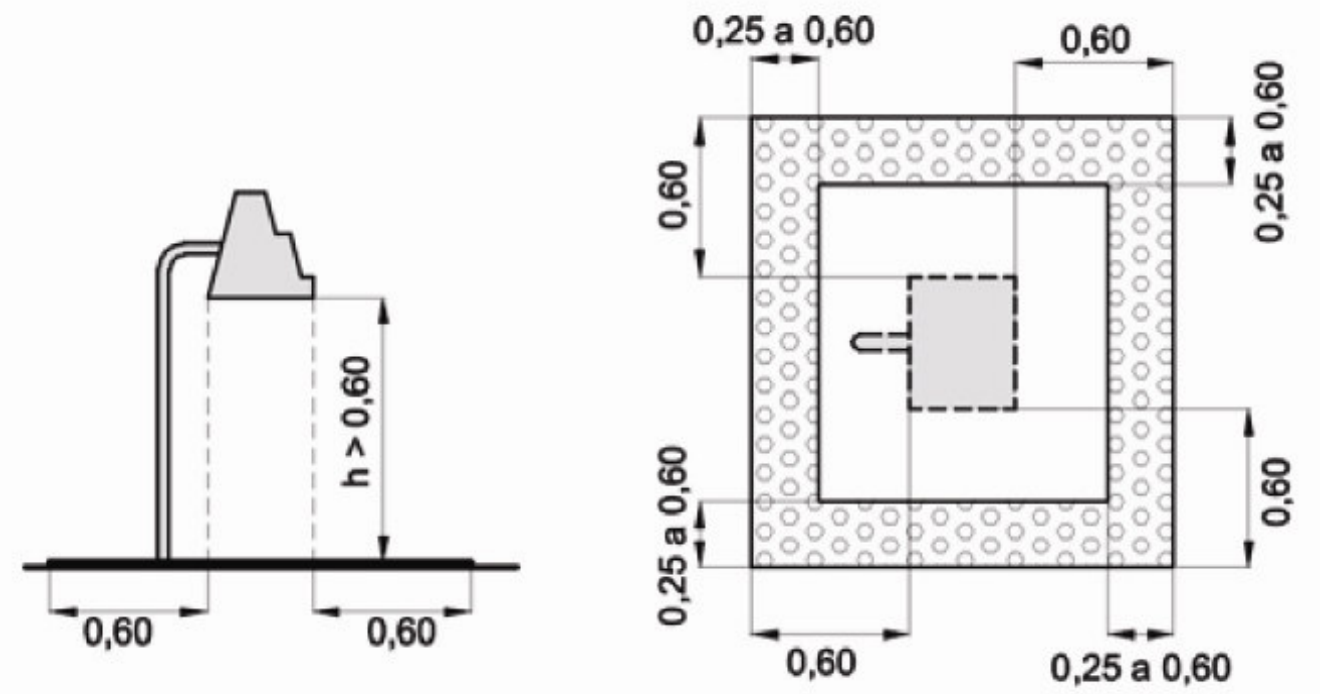

Figura 83 - NBR 9050/2004 - sinalização tátil para volumes suspensos.

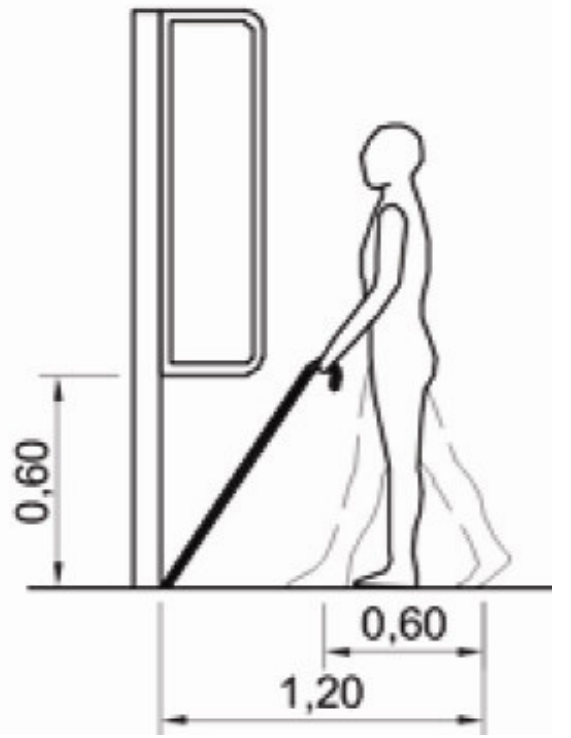

Figura 84 - NBR 9050/2004 bengala de rastreamento para pessoas com deficiência visual. 
Os pontos de ônibus do corredor da Avenida Rebouças atendem às exigências da NBR9050/2004, quanto à acessibilidade. Possuem piso elevado para facilitar a entrada nos veículos e piso tátil de alerta ao longo da plataforma, para orientar pessoas com deficiência visual. Esses pontos, têm abrigos cobertos, protegendo contra sol e chuva, bancos de espera e sistema de comunicação visual, que informam sobre as linhas que circulam no corredor de ônibus. Observou-se a falta de alternativas para que pessoas com deficiência visual possam informar-se sobre os ônibus que circulam por ali, seja por sistema sonoro ou leitura em Braille.

Para o presente trabalho, não se fez levantamento da quantidade e qualidade de ônibus adaptados aos cadeirantes, nesse corredor. O foco desta dissertação consiste na discussão da qualidade de projetos dos espaços livres públicos ou coletivos.

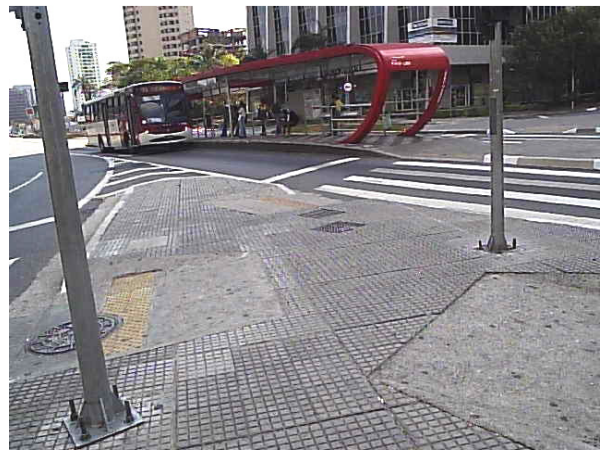

Figura 86 - Ponto de ônibus na Av.

Rebouças, próximo à Av. Brigadeiro Faria Lima.

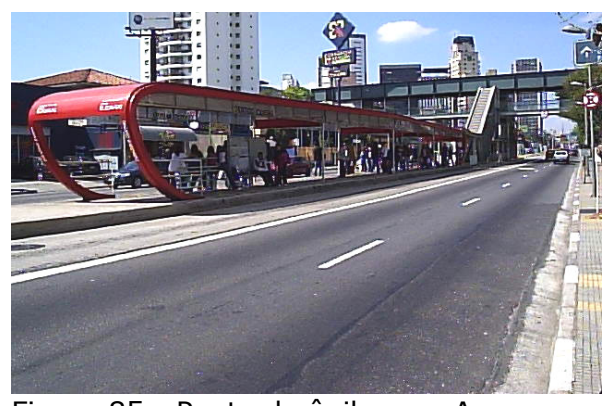

Figura 85 - Ponto de ônibus na Av. Eusébio Matoso, em frente ao Shopping Center Eldorado.

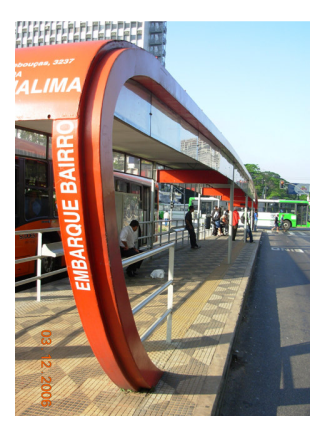

Figura 87 - Detalh de abrigo de

ônibus.Foto: Fábio 
Ao longo de quase toda a extensão da Avenida Rebouças, as calçadas estão em excelente estado de conservação. Porém, próximo ao cruzamento com a Rua Oscar Freire, as obras do Metrô causaram danos ao piso e esse foi remendado sem considerar qualquer dos aspectos do piso já existente.

A implementação da obra do Metrô desrespeita a condição do pedestre, ocasionando estreitamentos, buracos e saliências, mesmo no trecho em que as obras, na calçada, já foram terminadas.

Durante as fases de obstrução do passeio, não foi criado ou utilizado qualquer plano de rota alternativa, segura e acessível, para o caminhar do pedestre.

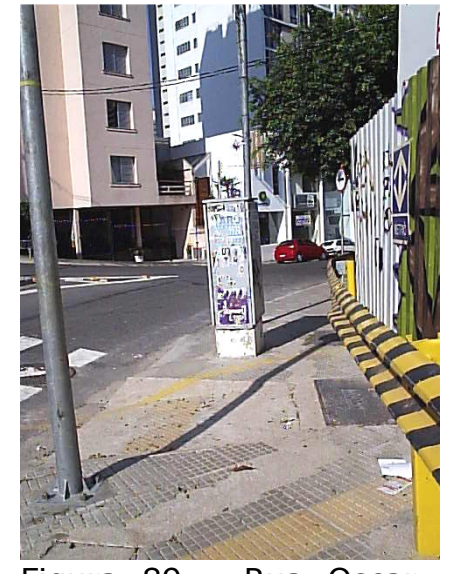

Figura 89 - Rua Oscar Freire esquina com a Av. Rebouças. "guardrail" atrapalhando a circulacão.

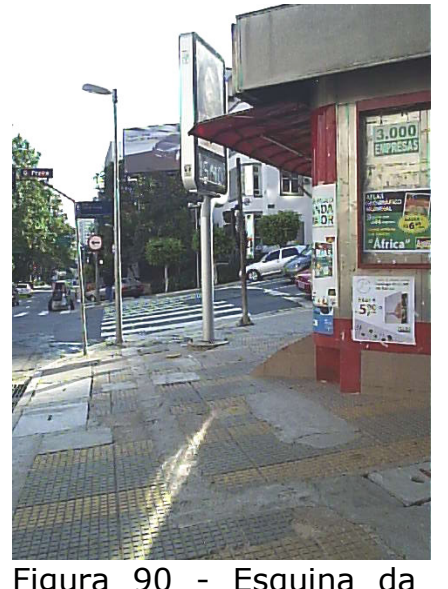

Rua Oscar Freire com a

Av. Rebouças. Emendas

no piso e mobiliário

urbano, dificultando a

circulação.

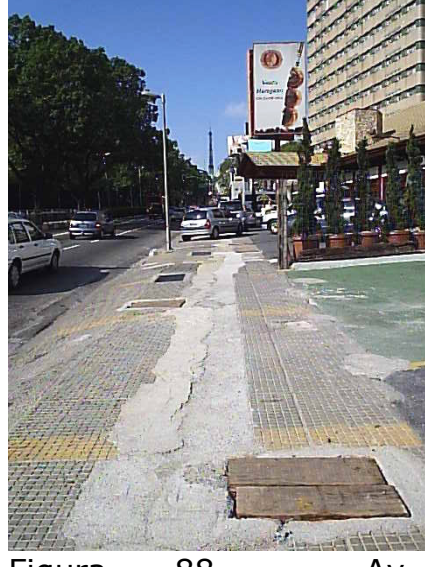

Figura $88-$ Av. Rebouças, próximo à Rua Oscar Freire, sentido centro. Emendas no piso desrespeitando o original.

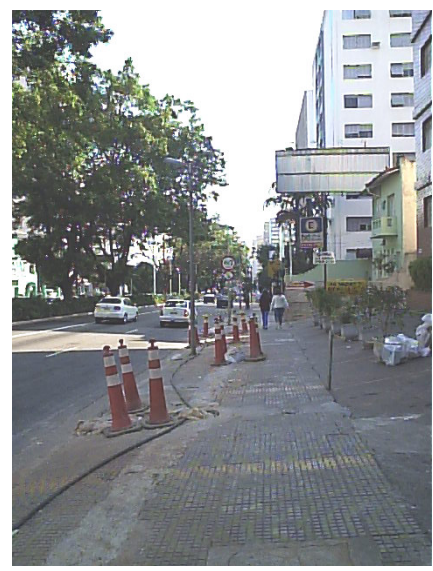

Figura 91 - Obras do Metrô, na Av. Rebouças, próximo à Rua Oscar Freire. Intervenções na calçada dificultando a circulação. 
Os postos de abastecimento de automóveis têm rebaixos por toda extensão, o que faz o caminhar inseguro ao longo desses lotes, pois os veículos podem cruzar o passeio em qualquer ponto. Falta sinalização tátil de alerta, junto às canaletas de contensão de óleo, para orientar pessoas com deficiência visual.

No caso da foto superior, esse posto de abastecimento, em frente ao Shopping Center Eldorado está com a pavimentação do passeio e as rampas em péssimo estado de conservação.

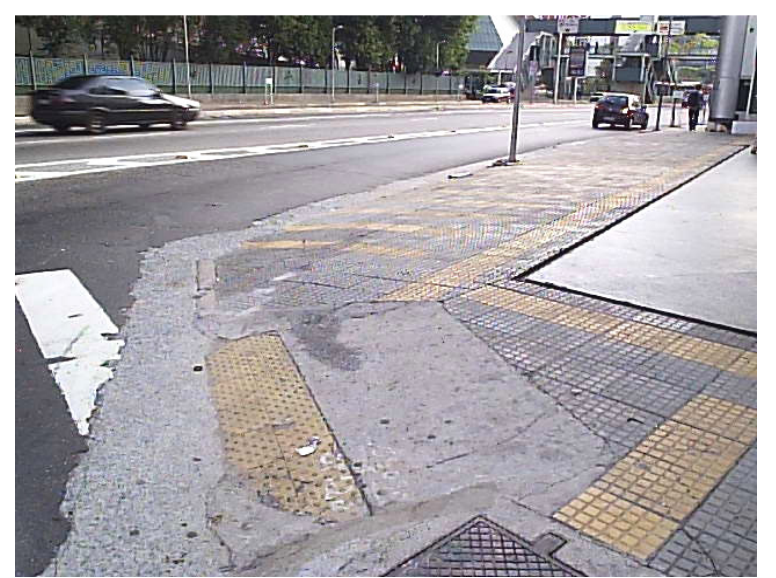

Figura 92 - Esquina da Av. Eusébio Matoso com a Rua Cardeal Arco Verde. Posto de gasolina, em frente ao Shopping Center Eldorado.

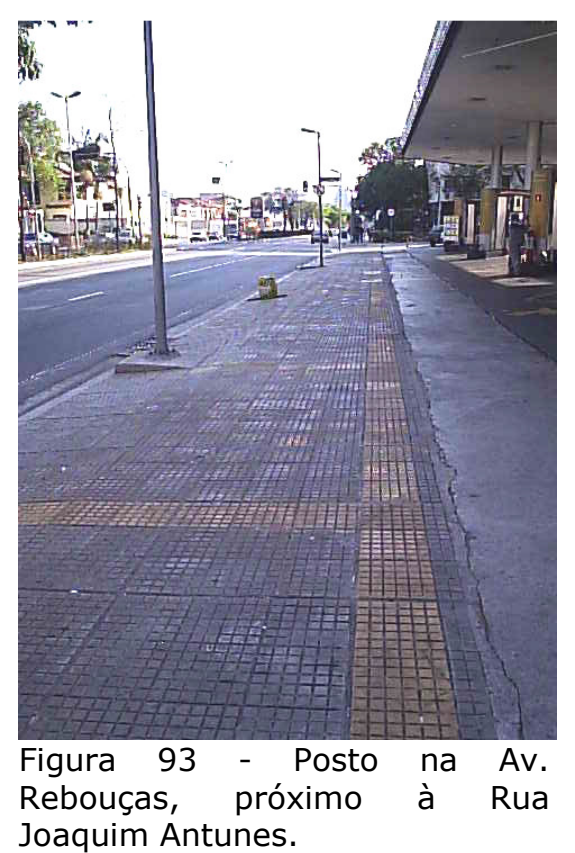

Joaquim Antunes. 
Com a reforma das calçadas, na Avenida Rebouças, os lotes tiveram que se adequar ao novo espaço, essas soluções nem sempre foram bem sucedidas.

$\mathrm{Na}$ foto inferior, por exemplo, a vaga para PCDs que é determinada por lei, mostra que a prática não consciente mantém o piso em estado bastante precário, impedindo o acesso universal e a segurança dos pedestres.

Figura 94 - Adequação entre a garagem do lote e a calçada padronizada.

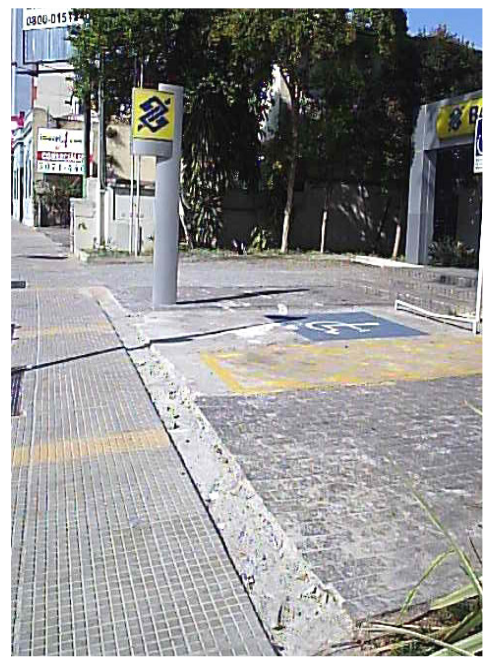

Figura 95 - Estacionamento do Banco do Brasil, junto à calcada reformada. 
$\mathrm{Na}$ foto superior, o encontro da Avenida Rebouças com a Alameda Gabriel Monteiro da Silva estreita o passeio, e os postes de iluminação prejudicam ainda mais, impedindo o caminhar em linha reta. No entanto, os ganhos qualitativos da reforma da calçada, são evidentes. Na foto inferior, na Alameda Gabriel Monteiro da Silva, pode-se observar o limite entre a área reformada e a calçada sem reforma. A calçada antiga possui inúmeros buracos, saliências e degraus, que inviabilizam a circulação de cadeirantes, por exemplo, problemas que foram bem resolvidos na reforma da Av. Rebouças.

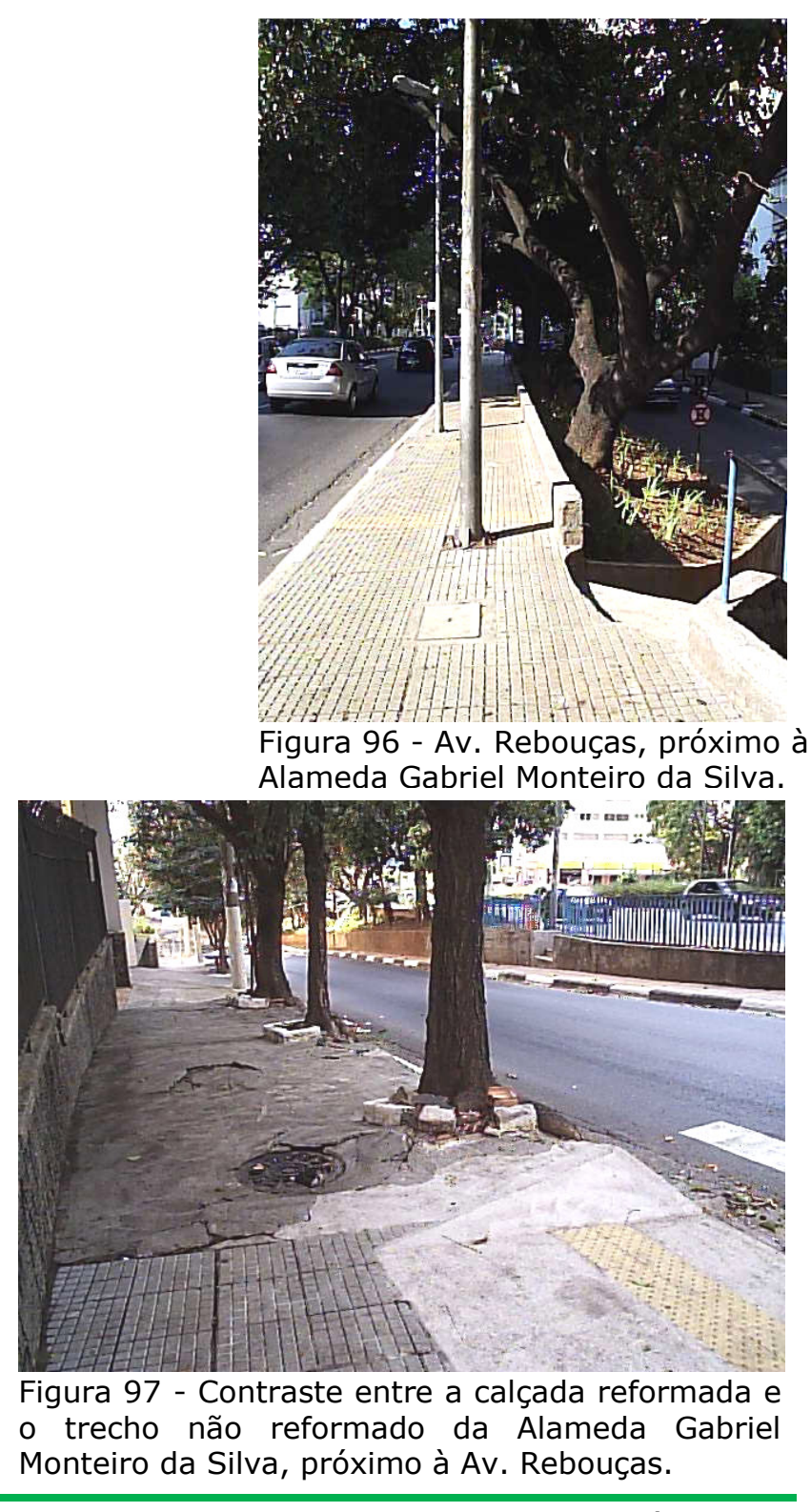

Página 140 
Próximo à Ponte Eusébio Matoso a passarela sobre a Avenida de mesmo nome, não fez parte da reforma. A inclinação é acentuada para o longo percurso. A Norma Brasileira de Acessibilidade (NBR 9050/2004) exige que, para a inclinação máxima permitida (8,33\%), existam patamares planos a cada $0,80 \mathrm{~m}$ de altura, o que não acontece, nesse caso.

Os corrimãos, daquela passarela, possuem extremidades salientes e podem causar acidentes. As alturas desses, estão incorretas, segundo a NBR 9050/2004, as alturas devem ser de $70 \mathrm{~cm}$ e $92 \mathrm{~cm}$, no caso em questão, possuem aproximadamente $50 \mathrm{~cm}$ e $110 \mathrm{~cm}$. As alturas exigidas pela Norma levam em consideração a estatura de uma pessoa em pé e de uma pessoa sentada, ou uma criança.

Pode-se observar que o guarda-corpo é utilizado como corrimão, porém a altura do primeiro deve ser maior do que a do segundo, de acordo com exigências de acessibilidade e do Corpo de Bombeiros.

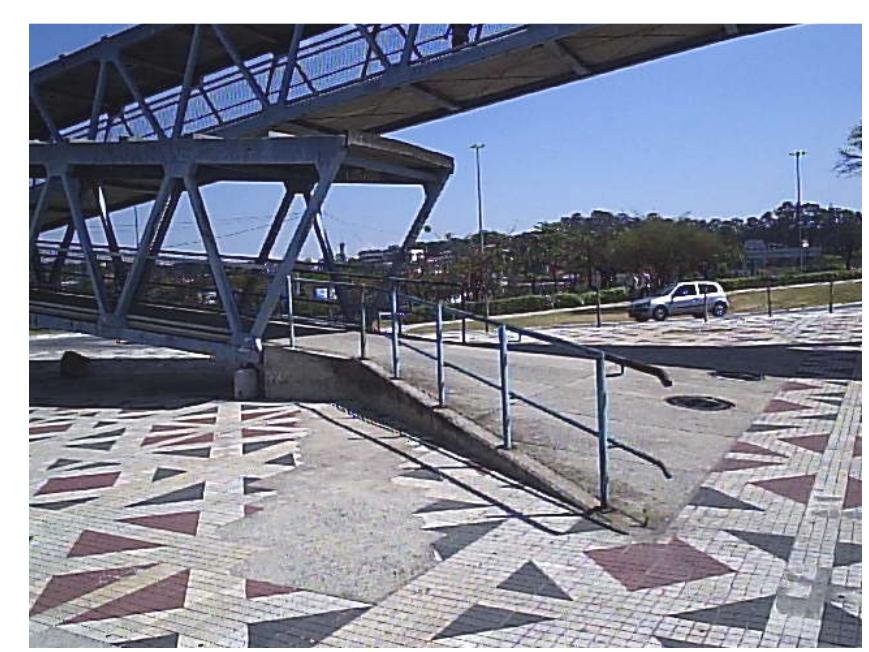

Figura 99 - Passarela próxima à Ponte Eusébio Matoso.

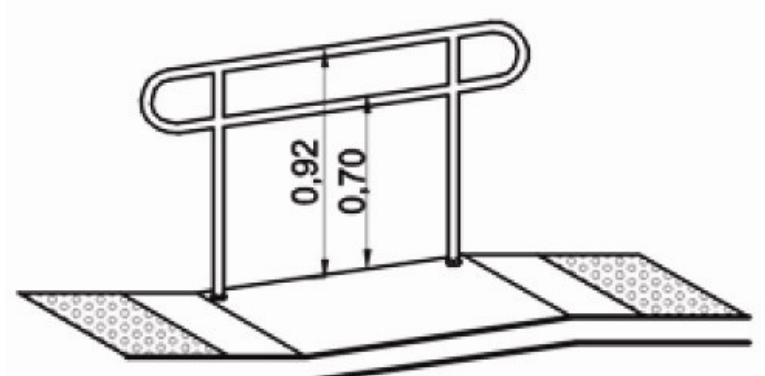

Figura 98 - NBR 9050/2004 - corrimão em rampas 
A passarela em frente ao Shopping Center Eldorado possui escadas, escadas rolantes e elevadores em ambos os lados da via e na ilha central de acesso à plataforma de embarque de ônibus. No entanto, esses elevadores, que estão sob responsabilidade do shopping, raramente funcionam.

Junto ao Hospital das Clínicas (HC), a passarela recebe, diariamente, cerca de 5.000 pessoas, segundo dados da CET. Essa passarela, recebe enorme quantidade de PCDs, porque se trata de um hospital de referência nacional e de grande porte, atraindo pessoas de toda São Paulo e até mesmo de todo Brasil.

O ponto de ônibus, sob a passarela é acessível, elevado, com piso tátil e coberto. Porém a escada que leva à passarela, mesmo sinalizada com piso tátil e dimensionada dentro dos padrões da ABNT, é extremamente cansativa o que incentiva a arriscada travessia da Avenida Rebouças.

Nessa passarela, próxima ao $\mathrm{HC}$, os dois elevadores existentes formam filas de espera e freqüentemente estão com problemas de manutenção.

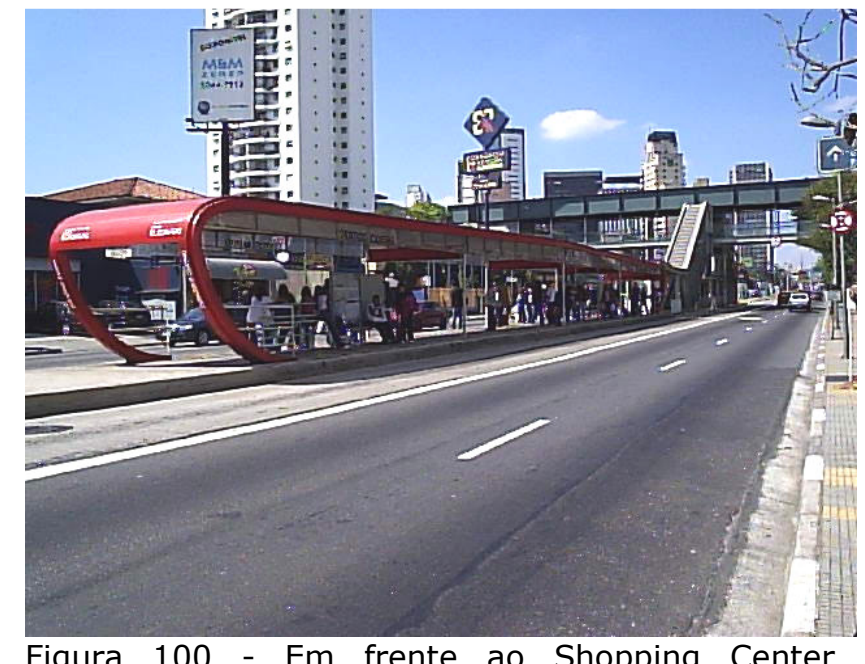

Figura 100 - Em frente ao Shopping Center Eldorado, ponto de ônibus e ao fundo, passarela de pedestres.

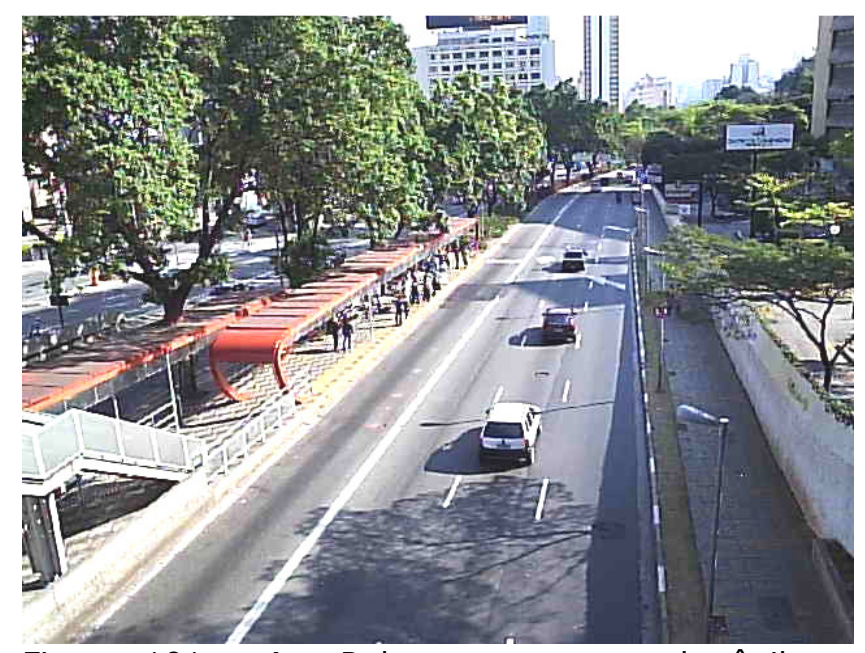

Figura 101 - Av. Rebouças e ponto de ônibus vistos de cima da passarela do Hospital das Clínicas. 
A mesma é extensa e de grande inclinação, tornando necessário grande esforço físico em seu percurso. Como dito anteriormente, de acordo com a Norma, para a inclinação máxima de 8,33\%, é necessário que haja patamares a cada $0,80 \mathrm{~m}$ de altura. Na passarela, em questão, há piso plano apenas em seu trecho mais elevado, pois o desenho corresponde, aproximadamente, a um arco abatido.

Sob a passarela das Clínicas, nas escadas de acesso junto ao Hospital (pista sentido Av. Marginal Pinheiros), faltam sinalizações de piso tátil de alerta no início e no término de ambas, para orientação de pessoas com deficiência visual e corrimãos, em duas alturas $(0,70 \mathrm{~m}$ e $0,92 \mathrm{~m})$, segundo a Norma.

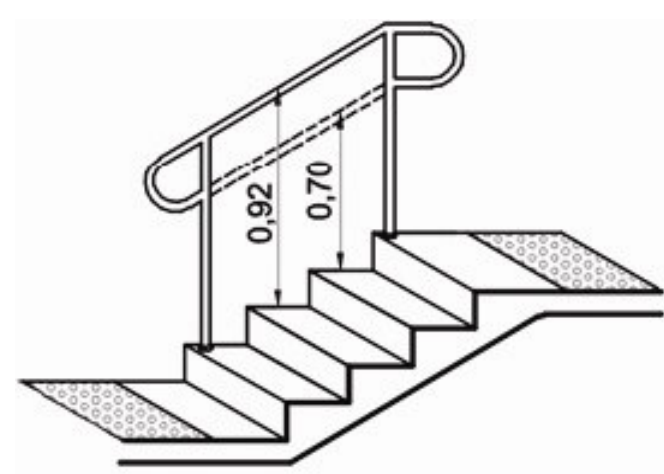

NBR 9050/2004 - escadas - piso tátil e corrimãos

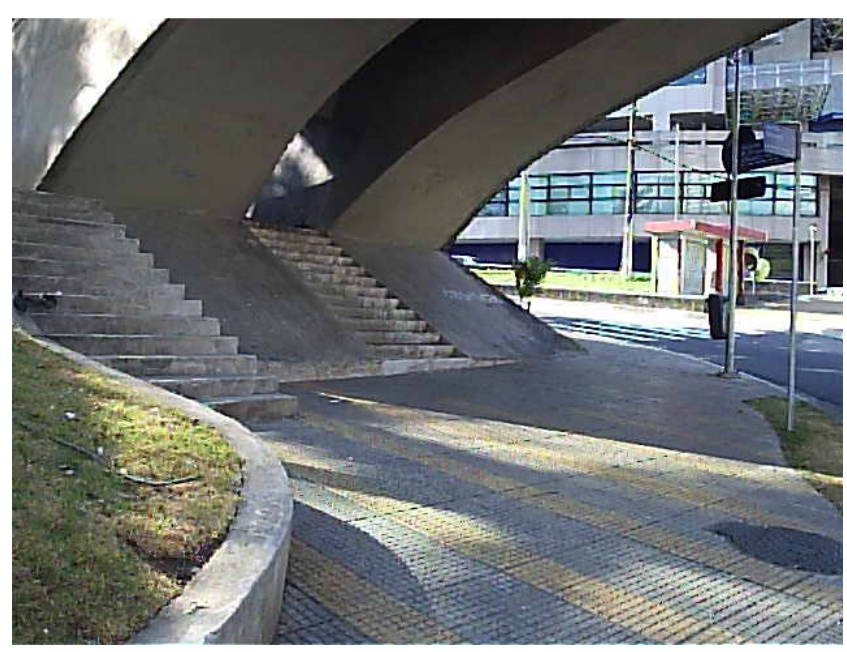

Figura 102 - Escadaria de acesso, sob a passarela do Hospital das Clínicas (Av. Rebouças).

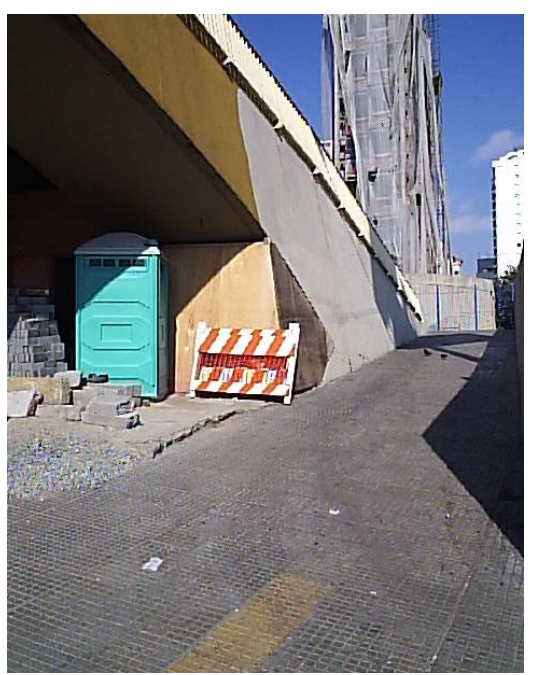

Figura 103 - Um dos acessos à passarela do Hospital das Clínicas (Av. Rebouças, sentido centro). 
Das barreiras encontradas, muitas foram ocasionadas por atitudes transitórias e inconscientes. As mais comuns, foram os veículos que ocupavam o passeio, forçando os pedestres a se esgueirarem por caminhos inseguros, ou até mesmo caminharem pela via.

Como as fotos deste estudo de caso foram tiradas em período de propaganda eleitoral, havia, também, publicidade política impedindo a circulação de pedestres nos rebaixamentos dos canteiros centrais das vias.

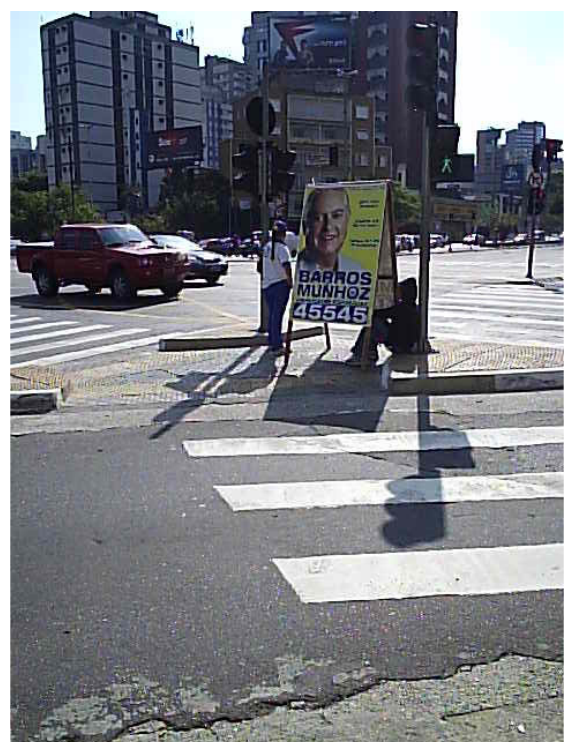

Figura 105 - Propaganda eleitoral sobre o caminho rebaixado, na ilha para travessia de pedestres (Av. Rebouças com a Av. Brasil).

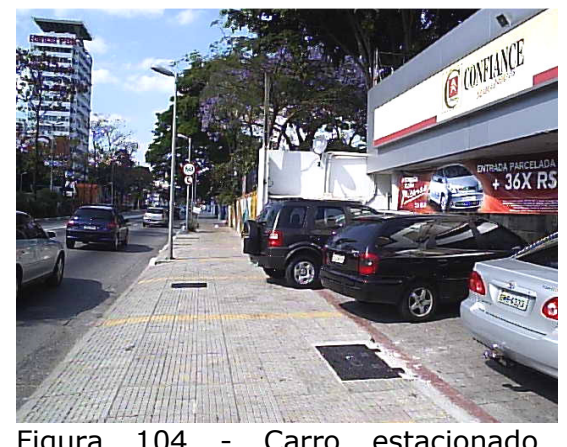

Figura 104 - Carro estacionado, invadindo a calçada da Av. Rebouças.
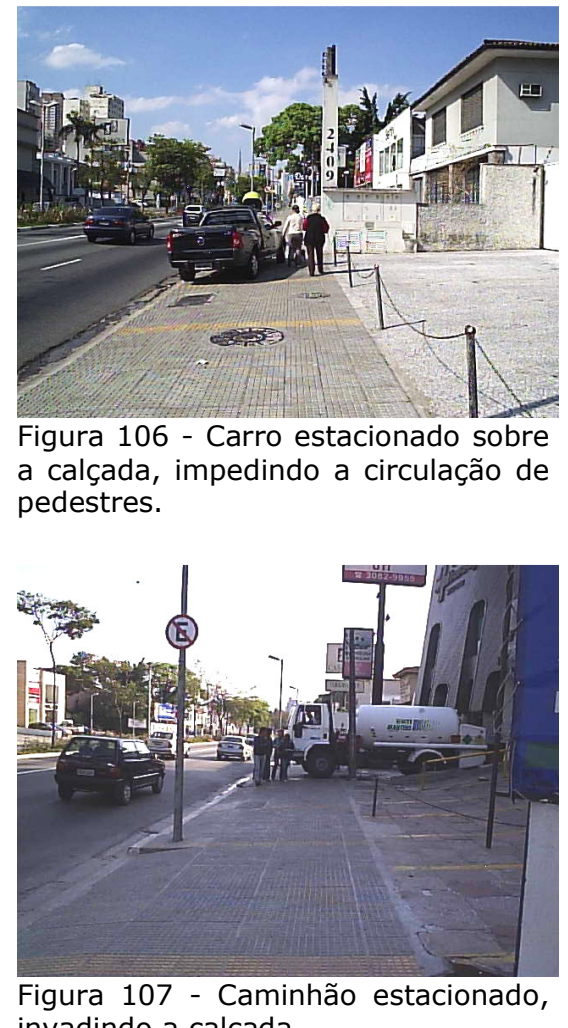
invadindo a calçada. 
Em frente a um restaurante, próximo ao Shopping Center Eldorado, foi utilizada uma solução interessante e propícia para situações em que a calçada é estreita para a implantação uma rampa convencional, com dimensões e inclinação recomendada por Norma, e que ainda permita espaço livre para a circulação mínima de 0,80m. A colocação do piso tátil está correta, porém faltou alinhar a rampa com a faixa de pedestres.

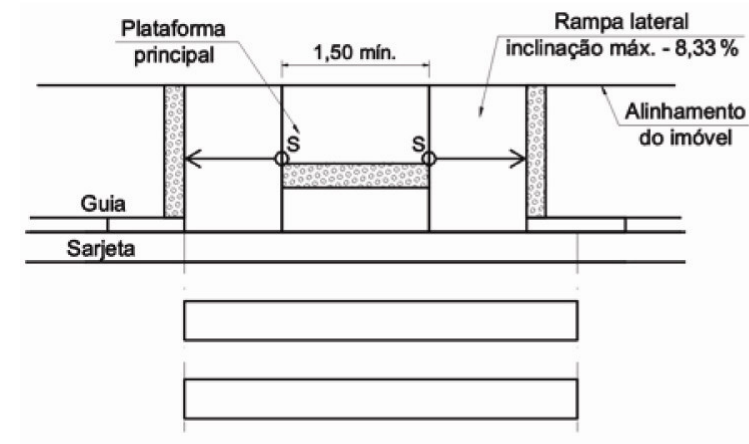

Vista superior

Figura 109 - NBR 9050/2004 - rebaixos de calçadas

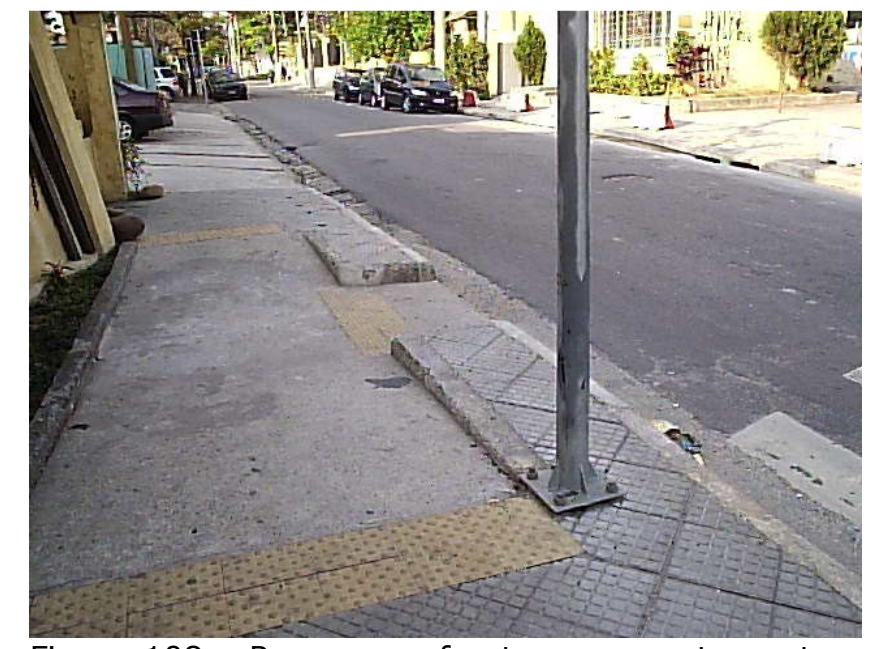

Figura 108 - Rampa em frente a um restaurante, próximo ao Shopping Center Eldorado, na calçada da Rua Diogo Moreira próxima ao cruzamento com a Av. Eusébio Matoso.

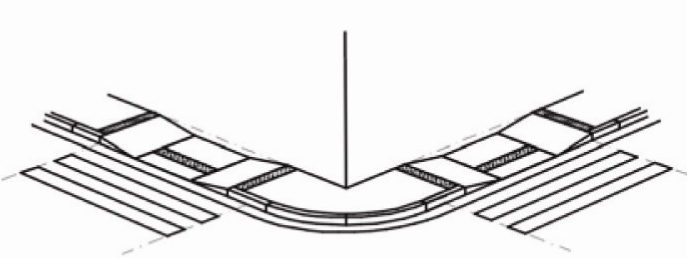

Perspectiva

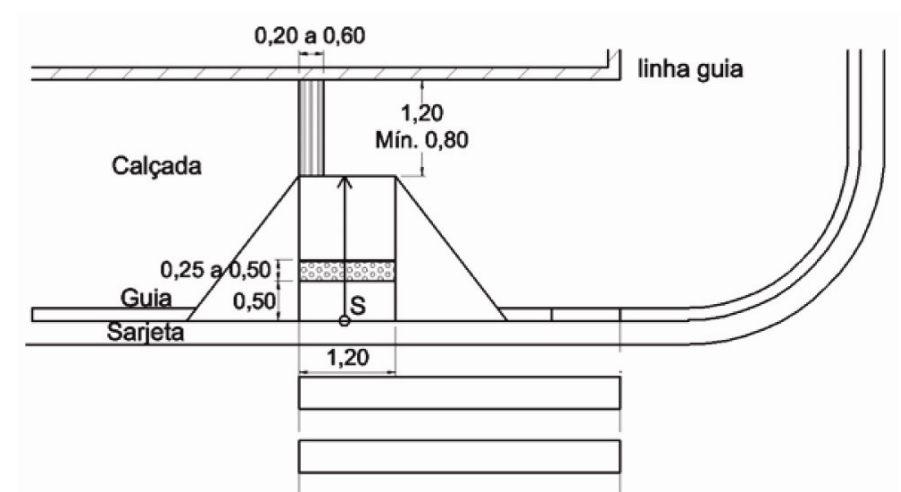

Figura 110 - NBR 9050/2004 - rebaixos de calçadas 


\section{Considerações finais - Av. Rebouças.}

O projeto, implantado na gestão da Prefeita Marta Suplicy e executado pela EMURB, possui piso de ladrilho hidráulico em bom estado de conservação na maior parte do percurso, excetuando-se apenas a área próxima às obras de instalação do Metrô, ali houve alteração de piso, decorrente das obras, e hoje se encontra bastante irregular.

A utilização de piso tátil de alerta foi feita nas rampas e também ao longo dos pontos de ônibus, atendendo aos parâmetros da ABNT e estão em bom estado de conservação.

A vegetação existente nas calçadas, da Avenida Rebouças, não é significativa e quando ocorre não apresenta dificuldades aos pedestres. A maior parte da vegetação está situada nos canteiros centrais.

Os pontos de ônibus são confortáveis e seguros, com abrigos contra intempéries do tempo. As travessias de acesso aos pontos de ônibus são feitas através de ilhas nos canteiros centrais, às quais reduzem as distâncias nos cruzamentos. Próximos aos pontos de 
ônibus existem obstáculos, para impedir a travessia incorreta, fora das faixas de pedestres, ainda assim, algumas pessoas conseguem ultrapassar as barreiras.

Atendendo à Norma, os pontos de ônibus são acessados por rampas sinalizadas com pisos táteis de alerta, nas mudanças de níveis, como solicita a Norma. Os pisos de acesso aos ônibus são elevados, facilitando a entrada nos veículos. Porém, durante todo o trajeto, não foi observada a circulação de ônibus adaptados para cadeirantes, o que requereria estudo para análise da situação.

Algumas questões de acessibilidade foram colocadas de forma equivocada, de acordo com os parâmetros estabelecidos pela NBR 9050/2004:

- Implantação de rampas não perpendiculares à faixa de pedestre, orientando a pessoa em cadeira de rodas ou com deficiência visual a atravessar pelo meio do cruzamento, correndo grandes riscos de atropelamento; 
- Rampas desencontradas obrigando pessoa, em cadeira de rodas, a mudar a direção da travessia em relação à faixa de pedestre para utilizar ambas;

- Nas travessias de pedestres existem semáforos e faixas de pedestres, porém o tempo, de abertura e fechamento do sinal, é em função do fluxo de veículos e não em função dos pedestres. Em alguns casos, como no cruzamento da Av. Rebouças com a Av. Brasil, são necessários passos rápidos para garantir travessia segura, tornando-se problema para pessoas com dificuldade de locomoção;

- Falta de sinalização sonora ou com piso tátil nas entradas e saídas de veículos dos lotes, para alertar pessoas com deficiência visual;

- Semáforos que não possuem alertas sonoros, sendo que esse recurso é importante para a orientação de pessoas com deficiência visual, durante as travessias e é exigido pela Norma, em locais de grande circulação de pedestres; 
- Telefones públicos que representam perigos de acidentes para pessoas com deficiência visual e que não estão sinalizados com piso tátil de alerta.

A quantidade de postes, em algumas esquinas, continua além da aceitável, para a circulação de forma contínua e linear, mesmo com a fiação elétrica enterrada. Nesse caso, poderiam ser utilizados os mesmos postes para diversas funções, por exemplo, colocando iluminação e placas de trânsito em um mesmo elemento.

É interessante perceber que alguns dos equívocos nas questões de acessibilidade partiram do projeto e não somente da execução. Isso pôde ser constatado através de desenhos fornecidos pela própria EMURB. Nesses, nota-se, por exemplo, a implantação errônea de rampas de pedestres não perpendiculares à faixa de travessia.

Durante todo o percurso, talvez $\circ$ maior entrave à acessibilidade sejam as "barreiras atitudinais", ou seja, aquelas que acontecem em função das diversas atitudes de pessoas no uso do espaço, no caso, o espaço público (por exemplo, estacionando automóveis sobre calçadas). Isso reflete a falta de consciência

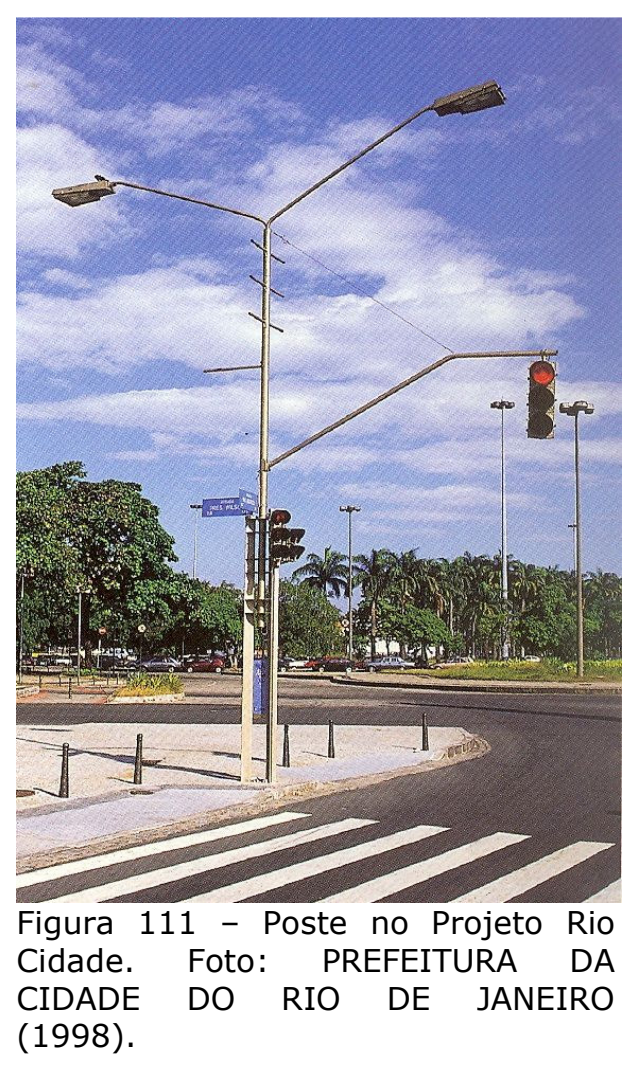

(1998). 
cidadã, pois esses costumes prejudicam qualquer pedestre, privilegiando atitudes particulares em detrimento da coletividade.

$\mathrm{Na}$ forma como atualmente se encontram, as calçadas da Avenida Rebouças são locais de fácil circulação, pois os pisos, de forma geral, estão muito bem conservados e a uniformização do percurso eliminou completamente os "degraus", os quais quase sempre ocorrem nas calçadas, em que não sofrem esse tipo de intervenção integrada. Em quase todas as travessias existem rampas de acesso para pessoa com deficiência, faixas de pedestres bem sinalizadas e semáforos.

Apesar de alguns problemas quanto à acessibilidade, as calçadas ganharam aspectos qualitativos de circulação e paisagem, os quais garantem a circulação de forma plena e segura, atendendo não apenas ao que determina a legislação, mas também a aspectos paisagísticos e de cidadania.

A reforma da Av. Rebouças foi executada com projeto e detalhamento das intervenções. Essa prática fez das calçadas espaços que passaram a atendem à acessibilidade, especialmente pelo cuidado com os detalhes, pois para atender a essas questões, esses pequenos detalhes representam a diferença entre a barreira e a acessibilidade. 


\section{Calçadas da Rua dos Pinheiros}

\section{Justificativa da escolha}

A Rua dos Pinheiros é interessante, porque sido reformada dentro dos parâmetros da Prefeitura, na gestão do Prefeito José

Serra, pela Companhia Metropolitana de São Paulo (Metrô), em função das obras da Linha 4 - Amarela (Vila Sônia - Luz).

Os ganhos com acessibilidade foram grandes, permitindo melhor circulação e apreensão do espaço, embora num pequeno percurso. 


\section{Apresentação da reforma das calçadas da Rua dos Pinheiros}

A Rua dos Pinheiros foi reformada pelo Metrô, durante a gestão José Serra, no ano de 2005 e 2006, segundo a Prefeitura. As obras duraram aproximadamente 12 meses e todo esse tempo sob várias reclamações e protestos dos comerciantes locais que, por conta dos transtornos, perderam muito em faturamento.

O início do trecho reformado corresponde ao cruzamento da Rua Mourato Coelho e termina na Rua Matheus Grou.

O piso utilizado é de blocos de concreto intertravado, com estampas que demarcam as faixas determinadas pela Prefeitura: faixa de serviço, faixa livre e faixa de acesso do lote.

As calçadas da Rua dos Pinheiros possuem aproximadamente $4 \mathrm{~m}$ de largura e a topografia, quase plana, favorece o atendimento das questões de acessibilidade. 


\section{Rua dos Pinheiros - roteiro fotográfico:}

As fotos apresentadas a seguir foram tiradas pela autora do trabalho, no dia 7 de setembro de 2006.

Na esquina da Rua dos Pinheiros com a Rua Mourato Coelho inicia o trecho que passou pela reforma do passeio. A rampa é feita do próprio piso e faz com que o espaço não fique extremamente demarcado com o rebaixo. Além de mais elegante, essa solução é bem mais econômica do que a utilização de rampas pré-moldadas de concreto, segundo técnicos da Prefeitura de São Paulo.

A rampa mostrada na foto não está perpendicular à faixa de pedestre, como determina a NBR9050/2004, seria importante atender aos parâmetros, para que as pessoas fossem orientadas na direção certa de travessia. A esquina, da foto, possui interferências que ocupam o que deveria ser a faixa livre, determinada pela Prefeitura, essa situação obriga mudanças desnecessárias de direção, interferências essas, criadas pelo próprio poder público.

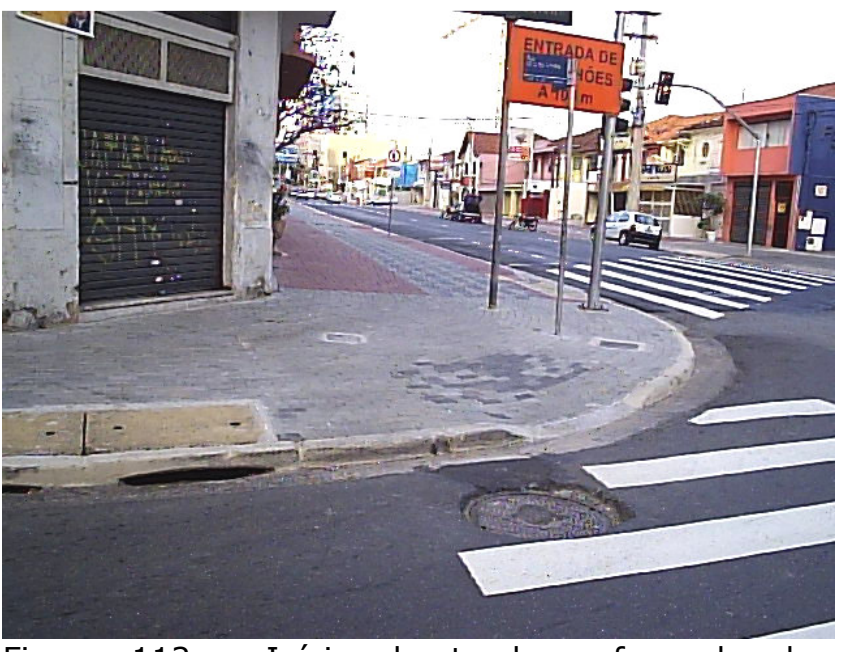

Figura 112 - Início do trecho reformado de calçada. Esquina Rua dos Pinheiros com a Rua Mourato Coelho. 
As três faixas determinadas pela Prefeitura estão demarcadas pela estampa da faixa central, a faixa livre. Pode-se perceber, na foto ao lado, que a calçada é larga (cerca de $4 \mathrm{~m}$ ) e que o percurso é contínuo e acessível. A utilização do piso tátil de alerta na rampa está correta, segundo os parâmetros da Norma, porém a rampa não está perpendicular à faixa de pedestres.

A mesma rampa pode ser vista em detalhe na foto inferior (ao fundo Rua Capitão Antônio Rosa). Ali, percebe-se, claramente, que não está perpendicular à faixa de pedestre, conduzindo para o cruzamento. Outra irregularidade encontrada, foi a inexistência de rampa correspondente, do outro lado da via.

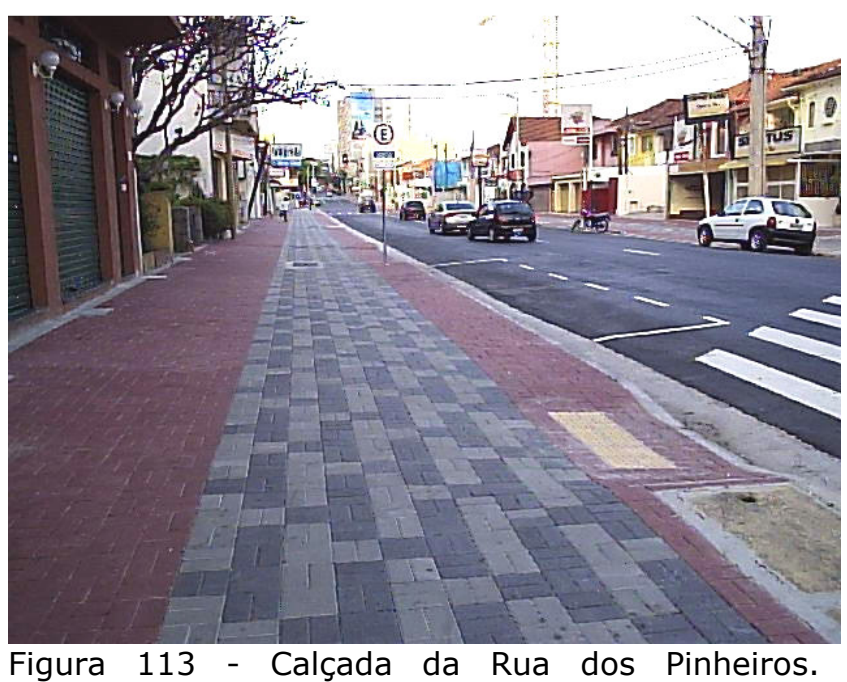
Demarcação das faixas de uso.

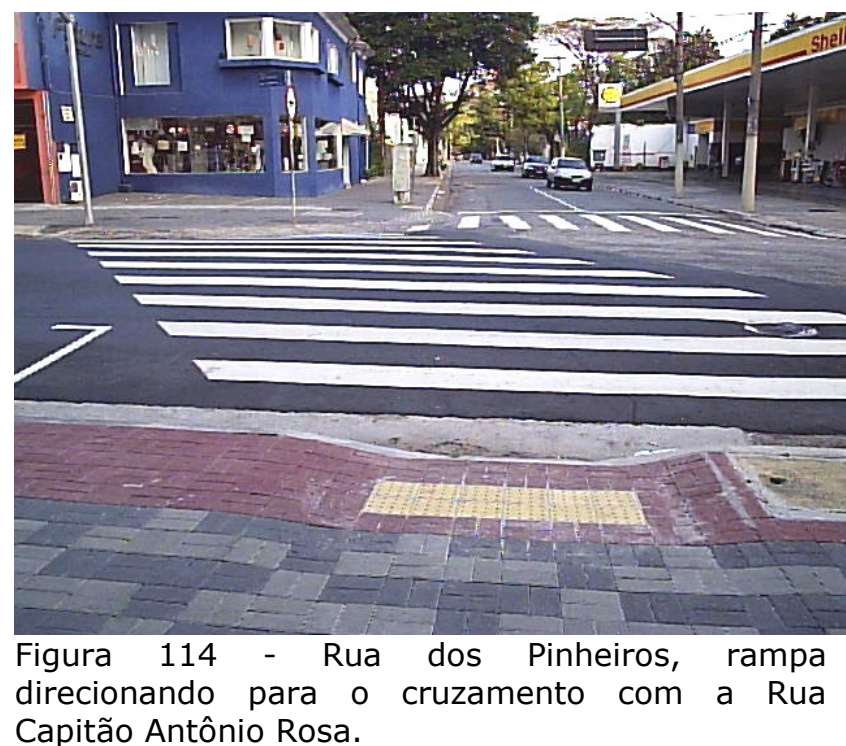


A faixa livre deveria estar livre de qualquer interferência, mas ao longo do percurso existem alguns tampos de concessionárias. Os rebaixamentos, para entrada de veículos no lote, estão ocorrendo nas três faixas, como pode ser visto na foto ao lado, sendo que isso não poderia ocorrer na faixa central (faixa livre), segundo os critérios do Programa Passeio Livre.

A travessia de pedestre, em frente à Rua Tecaindá, possui semáforo e a faixa de pedestre está bem demarcada. Esse semáforo não possui alerta sonoro para orientar pessoas com deficiência visual. Como o fluxo de pedestres, ness6e local, ainda não é grande, a Norma permite que esse semáforo não possua este dispositivo. No entanto, com a inauguração da Estação do Metrô, a necessidade de um sinalizador sonoro no semáforo poderá ser verificada.

A rampa, da foto inferior, possui suas dimensões adequadas e é perpendicular à faixa de pedestre, de acordo com a NBR9050/2004.

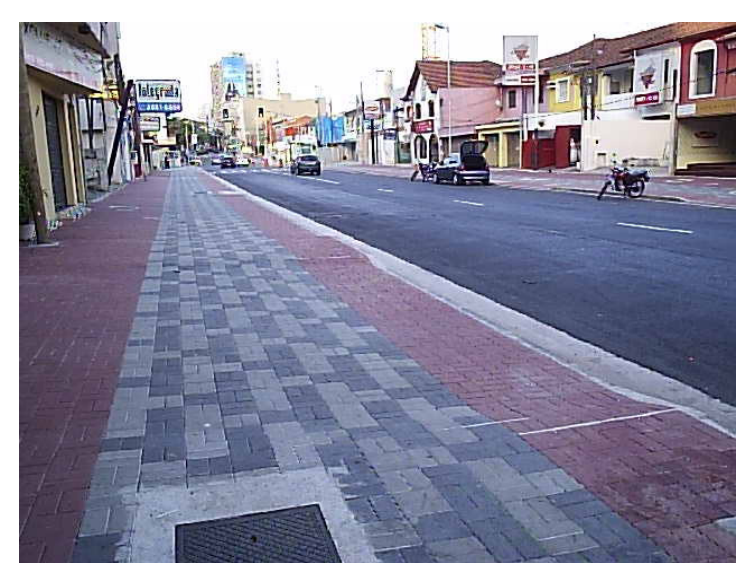

Figura 116 - Calçada na Rua dos Pinheiros. Observar tampo na faixa livre e desníveis para entrada de automóveis.

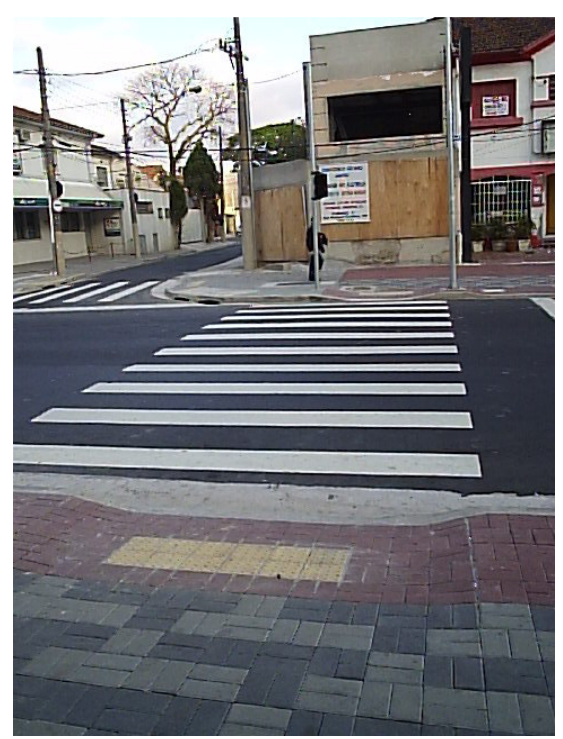

Figura 115 - Rampa e faixa de pedestres - Rua dos Pinheiros, em frente à Rua Tecaindá. 
No cruzamento com a Rua Fradique Coutinho, fechada ao fluxo de pedestres e veículos, inicia-se a área do canteiro de obras do Metrô. Nesse trecho há estreitamento do passeio (de aproximadamente $4 \mathrm{~m}$ passa a ter cerca de $1,5 \mathrm{~m}$ ). Foram instaladas rampas para essa travessia, de forma provisória, utilizando solução e linguagem diferente daquela utilizada ao longo do percurso, como na foto superior.

O estreitamento do passeio ocorre de tal forma, que as pessoas passam a circular na faixa de serviço e em parte da faixa livre, encontrando obstáculos como, postes para a sinalização da via e cestos de lixo, instalados pelo próprio Metrô.

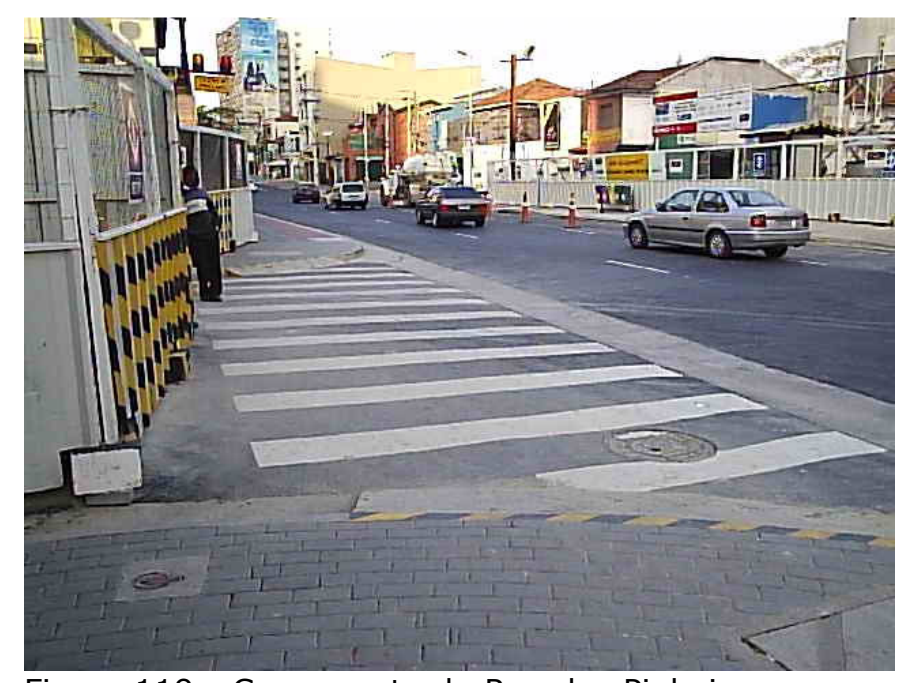

Figura 119 - Cruzamento da Rua dos Pinheiros com a Rua Fradique Coutinho, fechado pelas obras do Metrô.

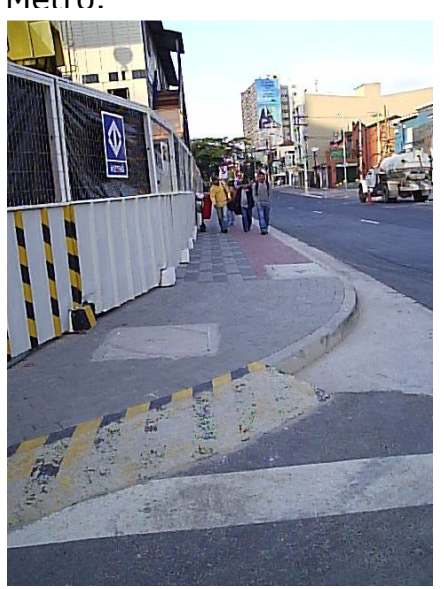

Figura 118 -

Estreitamento do passeio.

Rua dos Pinheiros com a

Rua Fradique Coutinho.

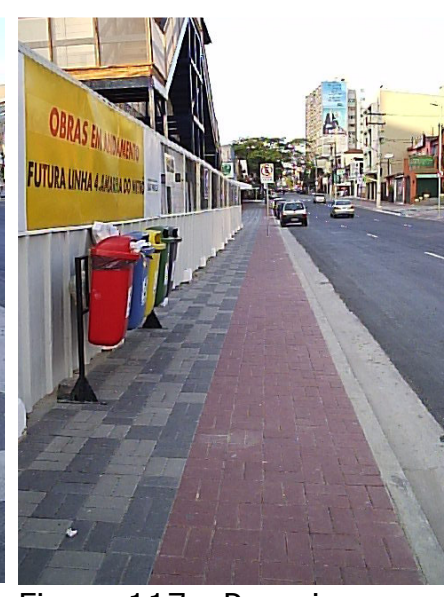

Figura 117 - Passeio

estreitado pelas obras do Metrô e pelo uso de mobiliário urbano (lixeiras). 
A reforma do passeio resultou em alguns problemas nas fronteiras com os lotes, para resolver essa situação, os proprietários poderão ocupar a faixa de acesso para fazer a interface. Essa pode ser utilizada para a colocação de pequenas rampas para as garagens, mesas de bares, vasos de plantas, e está prevista a possibilidade de ocupação dessa faixa por automóveis, de acordo com o Decreto 45.904 de 2005, "a faixa de acesso poderá conter (...) a implantação de estacionamento em recuo frontal, desde que respeitada a faixa de transição entre os veículos e a faixa livre de circulação".

Na foto superior, vê-se ao fundo, o canteiro de obras que estreita o passeio e mais à frente, veículo ocupando a faixa de acesso e parte do lote.

No cruzamento da Rua dos Pinheiros com a Rua Matheus Grou, um estabelecimento interrompe a reforma, impedindo a continuidade do passeio até à esquina. Neste local, são colocadas mesas sob a área coberta e o piso é elevado, criando desníveis na direção do caminhamento do pedestre, impedindo a acessibilidade e os pedestres são forçados a seguirem pela faixa de serviços.

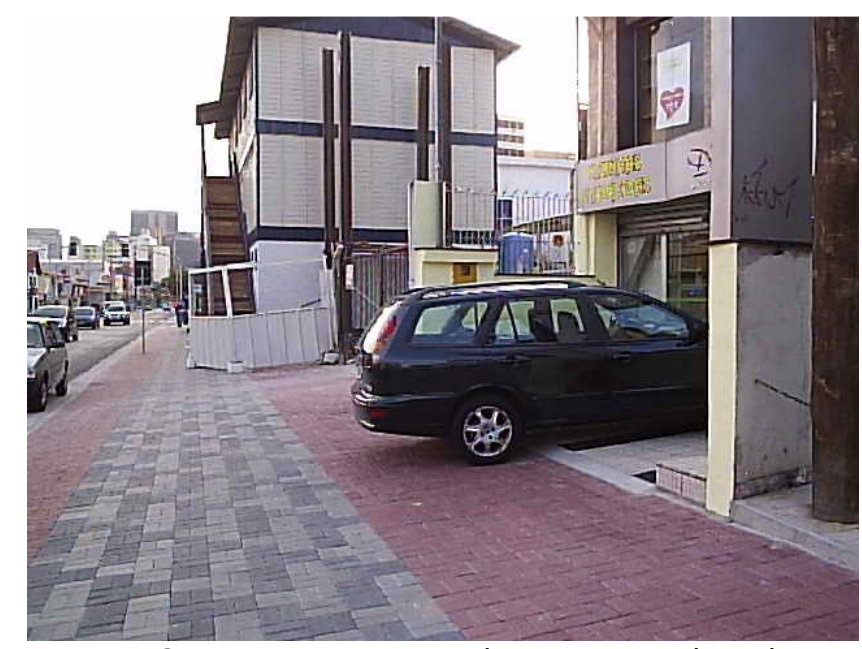

Figura 121 - Estreitamento do passeio pelas obras do Metrô. Observar automóvel invadindo a calçada na faixa de acesso ao lote.

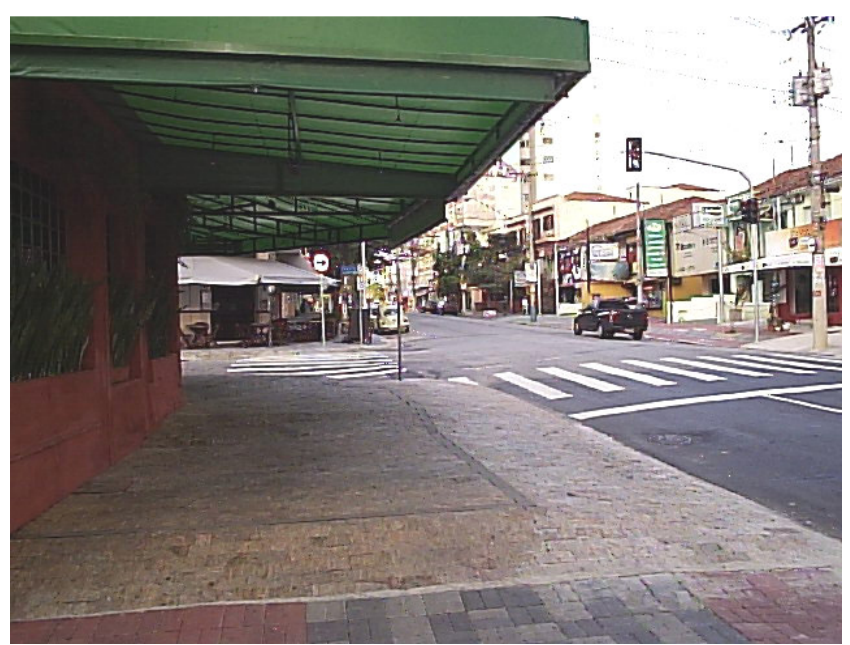

Figura 120 - Calçada na esquina do encontro da Rua Matheus Grou com a Rua dos Pinheiros. 
Descendo a Rua dos Pinheiros, do lado esquerdo, de frente para Rua Mateus Grou, chamou a atenção um trecho cuja reforma não foi aplicada integralmente, porque um pequeno canteiro para vegetação está exatamente na faixa livre. Não se trata de espécie vegetal de fundamental importância, nem de porte expressivo, mas por algum motivo foi mantido. Os degraus em frente a esse estabelecimento e o vaso de plantas, como se vê na foto, estão dentro da faixa de acesso do lote e, portanto, não infringem as determinações da Prefeitura.

Outra "concessão" observada, no mesmo loca, foi uma rampa que faz a ligação entre a rua e o lote, ocupando a largura total do passeio, criando degraus e mantendo o piso com excessiva inclinação transversal ao fluxo.

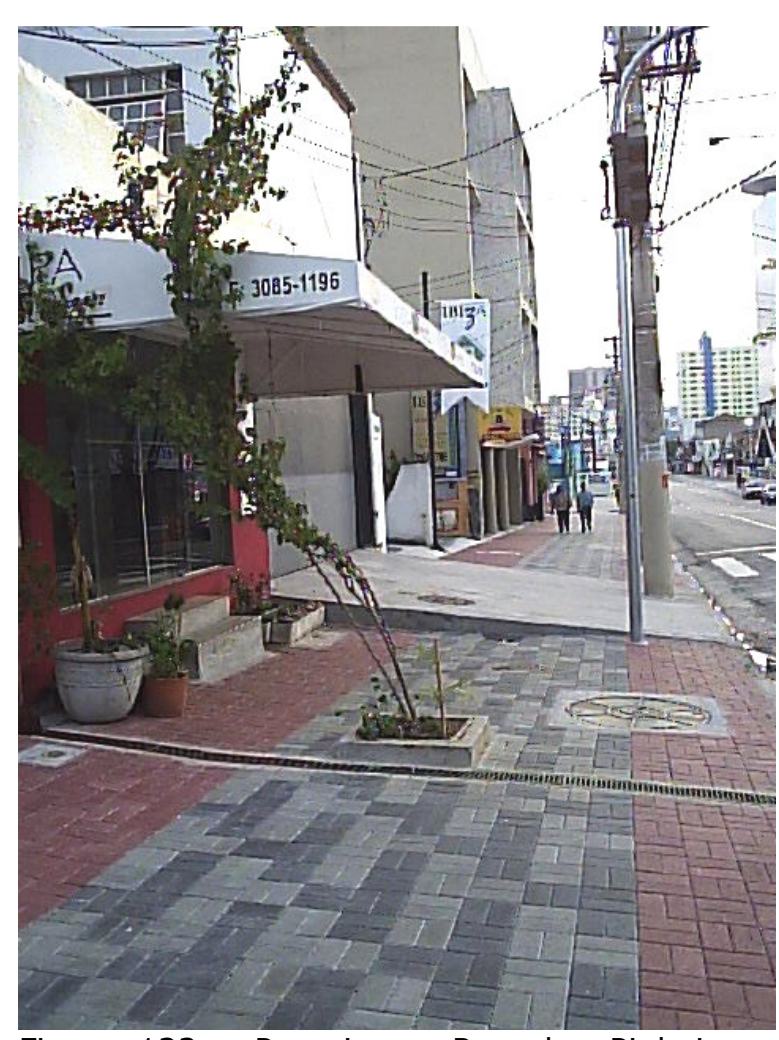

Figura 122 - Passeio na Rua dos Pinheiros. Observar floreira e rampa de acesso ao imóvel obstruindo a faixa livre. 
O rigor da reforma, de acordo com as determinações da Prefeitura, é encontrado na maior parte do percurso. É possível, também, observar o contraste entre a forma da calçada e a situação dos lotes, estes não fizeram interface com a calçada reformada.

No trecho de obras do Metrô, observaram-se inúmeros obstáculos temporários ao pedestre, ocasionados pela reforma. Esses obstáculos ocorrem com freqüência e não há opção alternativa e segura para o fluxo de pessoas. Na foto inferior, pode-se ver que os cones na via (ao fundo) são para orientar o fluxo de veículos em relação ao caminhão estacionado e não para proteção de pedestres.

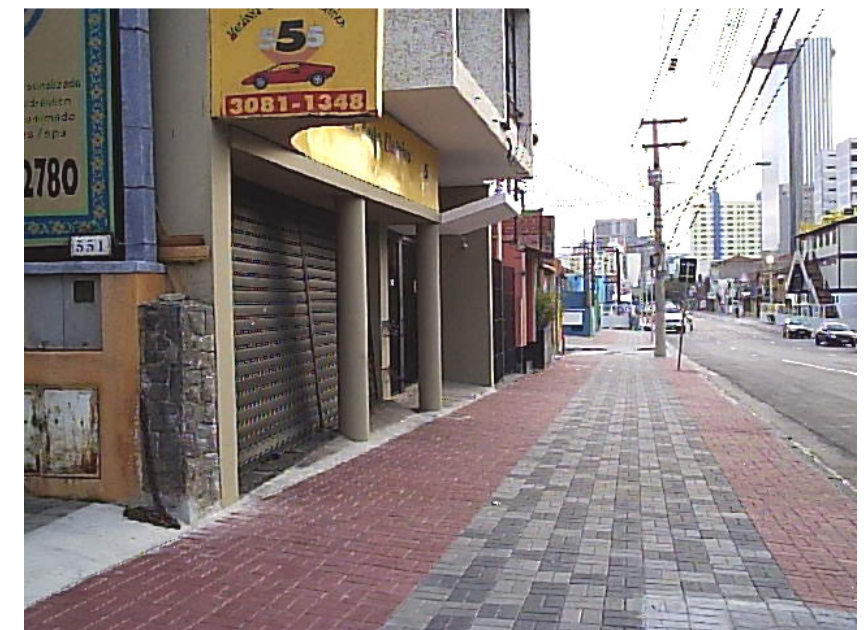

Figura 124 - Rua dos Pinheiros. Observar interface entre o passeio e os lotes.

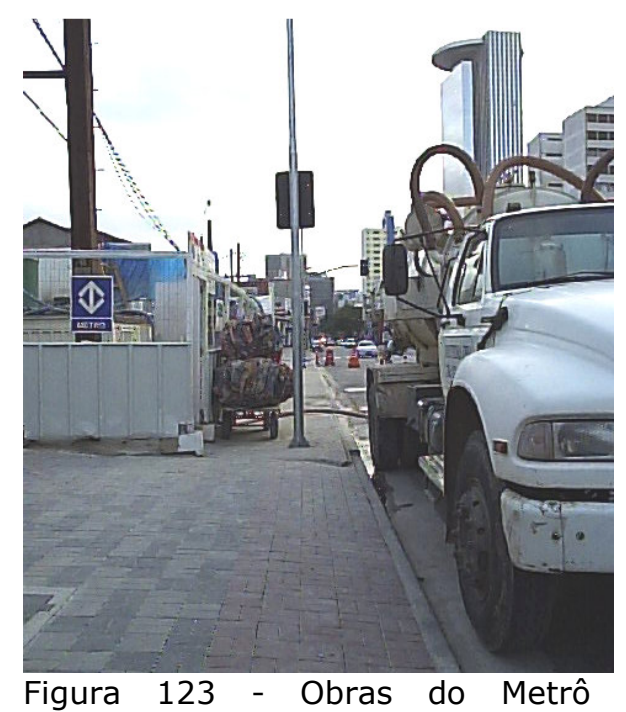
ocupando a calçada da Rua dos Pinheiros, sentido Av. Marginal do Rio Pinheiros. 
O piso da calçada, no trecho de obras do Metrô, no lado esquerdo para quem desce sentido Marginal do Rio Pinheiros, era de cimento rústico e a largura do passeio foi reduzida (aproximadamente $2 \mathrm{~m})$, sem causar estrangulamento de fluxo de pedestres. Esta observação ocorreu durante o roteiro fotográfico.

No cruzamento da Rua dos Pinheiros com a Rua Capitão Antônio Rosa, onde a reforma do passeio termina, é possível observar o quanto a reforma trouxe de melhorias em acessibilidade e ganhos de paisagem.

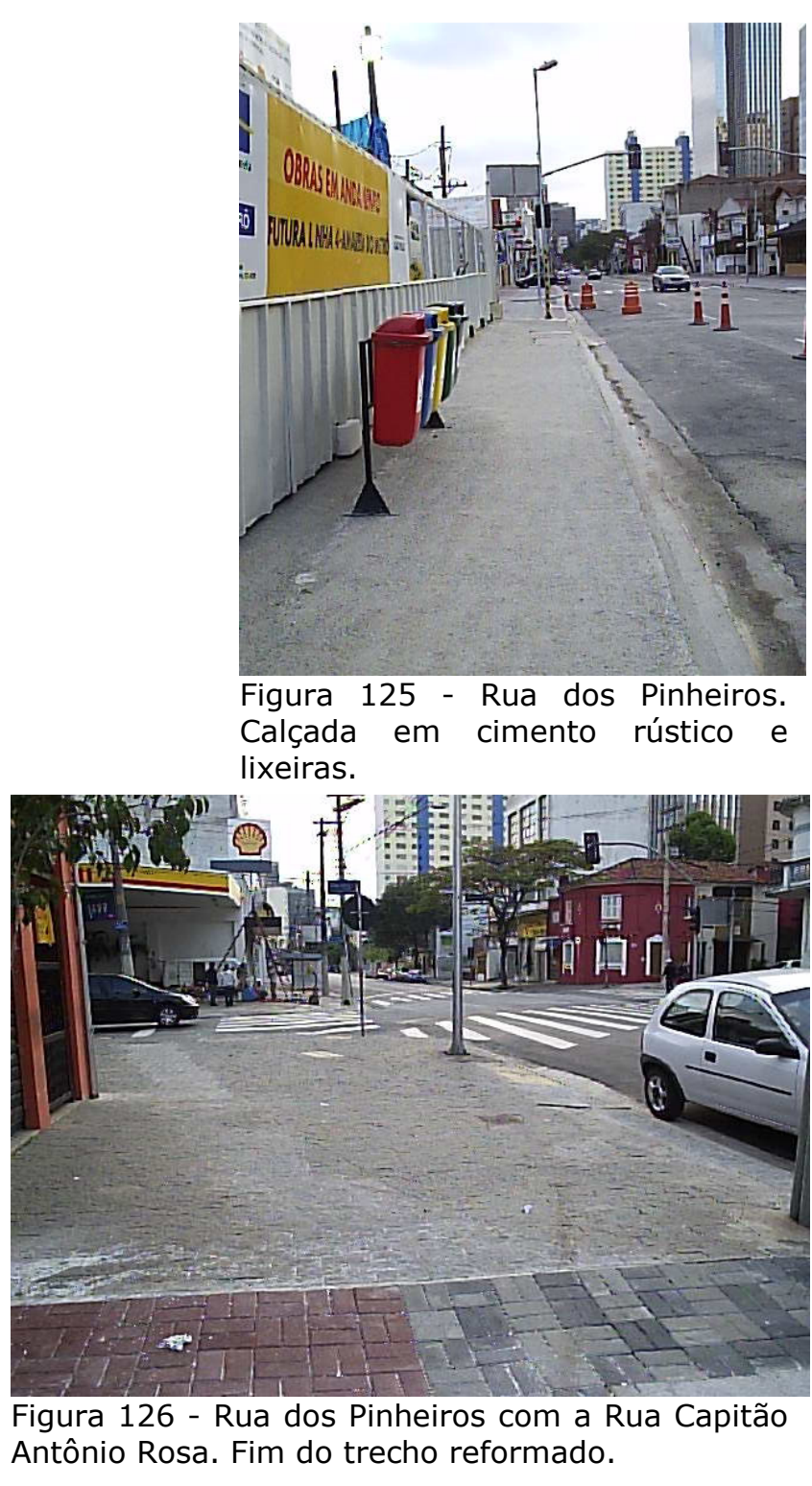

Página 160 


\section{Considerações finais - Rua dos Pinheiros}

O projeto foi implantado na gestão do Prefeito José Serra e executado pelo Metrô. O piso é de blocos de concreto intertravado e o desenho segue a proposta do Programa Passeio Livre, de tal forma que as três faixas (livre, de serviço e de acomodação) são demarcadas pelas estampas.

A utilização dos blocos intertravados possibilita reformas de piso sem gerar entulho, pois as peças podem ser removidas sem a necessidade de quebras.

As rampas são feitas do próprio piso e sobre ele foram colocados os pisos táteis de alerta. Esse tipo de rampa, além de não demarcar excessivamente os rebaixos para travessia de cadeirantes, torna-a parte integrante do trajeto, também no aspecto visual. Segundo José Renato Melhem (coordenador do Programa Passeio Livre), a rampa moldada no próprio piso custa um terço do valor da rampa pré-moldada de concreto.

A colocação dos blocos foi bastante cuidadosa, resultando num piso sem saliências, evitando-se grandes trepidações no uso de cadeiras de rodas. 
Quanto à fiação aérea, observou-se que não foi enterrada, e as esquinas continuam com excessiva quantidade de postes em função também da sinalização de trânsito.

A faixa livre possui alguns tampos de concessionárias, contrariando o que determinada a Prefeitura, pois esses deveriam estar na faixa de serviço.

Não foi observada a existência de semáforos com alertas sonoros, necessários para orientação de pessoas com deficiência visual, exigidos pela NBR9050/2004, em locais com grande fluxo de pedestres, o qual ocorrerá, de forma mais intensa, após a inauguração da estação do Metrô.

Quanto à rampa de acomodação para entrada do veículo, segundo os parâmetros da Prefeitura, quando não for suficiente na faixa de serviço, deve-se resolver o problema do lote para dentro. No entanto, essa condição foi desrespeitada por um dos estabelecimentos da Rua dos Pinheiros.

Sobre o processo de padronização das calçadas, a Rua dos Pinheiros possui projeto e detalhamento para a reforma. Por isso 
observou-se a qualidade na execução dos trabalhos, a qual garante a acessibilidade.

A reforma, de modo geral, trouxe grandes ganhos na circulação de pedestres. Foi eliminada grande parte das interferências na calçada, especialmente as rampas transversais ao fluxo, utilizadas para entrada de veículos, que geravam degraus no percurso. Atualmente, a calçada permite o caminhar contínuo ao longo de todo o trajeto reformado.

O trecho em que o Metrô ainda está em obras, a calçada, apresenta menor qualidade, por estar em transformação. Ainda assim, seriam necessários cuidados com as interferências no passeio, mesmo que temporárias, garantindo aos pedestres opções de rotas seguras e acessíveis, no caso de desvios.

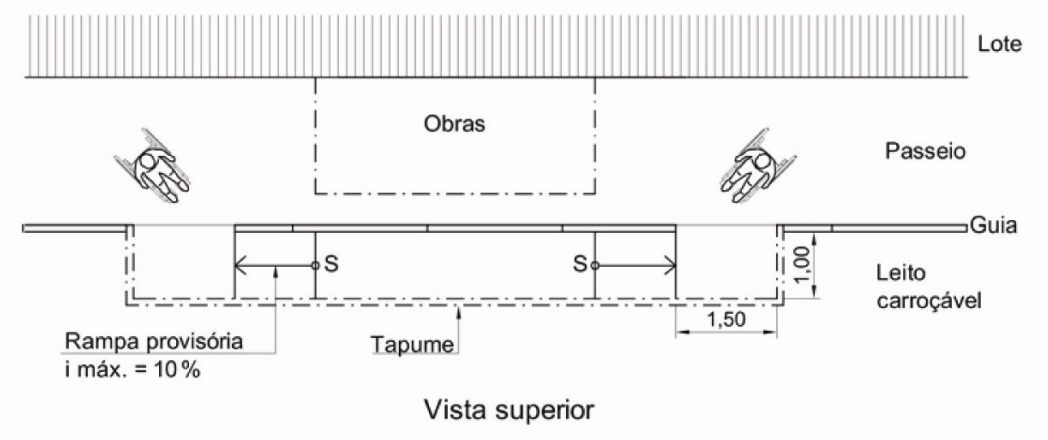

Figura 127 - NBR 9050/2004 - rampas de acesso provisório 


\section{Calçadas da Rua João Cachoeira}

\section{Justificativa da escolha}

A Rua João Cachoeira, segundo a Prefeitura, foi a primeira de um conjunto de ruas, na cidade de São Paulo, onde os lojistas uniram-se em parceria com a prefeitura e realizaram a reforma de um trecho de calçadas, nos moldes do Programa Passeio Livre.

As calçadas foram reformadas e o mobiliário urbano redesenhado, com a intenção de obter-se um "shopping a céu aberto". 


\section{Apresentação da reforma das calçadas da Rua João Cachoeira}

Segundo a Prefeitura, a Rua João Cachoeira, em 2003, foi a primeira a ser reformada dentro do Programa de Ruas Comerciais, ligado ao Programa Passeio Livre.

Por tratar-se de iniciativa dos próprios lojistas, a reforma teve grande aceitação, diferenciando-se do ocorrido na Avenida Rebouças e Rua dos Pinheiros.

Os custos da obra das calçadas da Rua João Cachoeira foram financiados pelos próprios comerciantes, que como contrapartida, tiveram a possibilidade de fazer seus anúncios no mobiliário urbano ao longo do trecho reformado.

Na reforma foi recapeado o asfalto, os postes de iluminação foram substituídos, as calçadas padronizadas e as fachadas das lojas refeitas, dentro da idéia de transformar o conjunto em "um shopping center a céu aberto".

O percurso reformado corresponde a três quarteirões (da Rua Jesuíno Arruda à Rua Leopoldo Couto de Magalhães), cerca de $900 \mathrm{~m}$, de acordo com a Prefeitura, e as calçadas possuem aproximadamente $3 \mathrm{~m}$ de largura, ao longo deste trecho. 


\section{Rua João Cachoeira - roteiro fotográfico}

As fotos apresentadas a seguir, foram tiradas pela autora deste trabalho, no dia 9 de setembro de 2006.

Na Rua Jesuíno Arruda, esquina com a Rua João Cachoeira (sentido Avenida Presidente Juscelino Kubitschek - lado direito) inicia-se o trecho do projeto de reforma.

O piso é de blocos de concreto intertravado e as rampas de concreto pré-moldado. Essa solução propicia fácil percepção de mudança de texturas de pisos, facilitando a localização da travessia pela pessoa com deficiência visual.

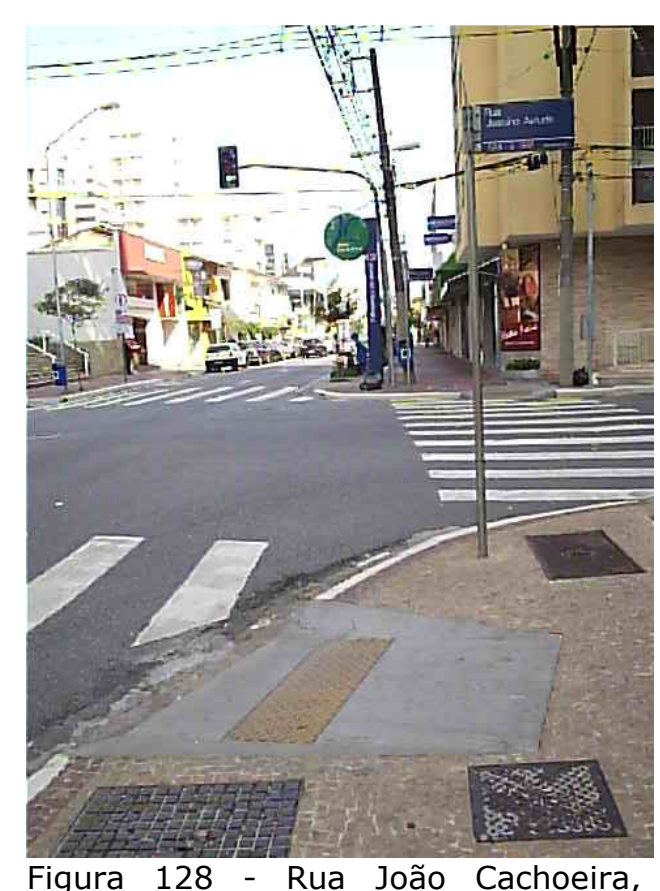

esquina com a Rua Jesuíno Arruda. 
Em alguns trechos dos passeios, próximos às esquinas foram criados ambientes de descanso, possibilitados pelo alargamento da calçada e, conseqüentemente, estreitamento da via. Esse estreitamento possibilita a travessia de forma mais rápida e segura, em função da diminuição do percurso e da necessidade dos carros diminuírem a velocidade. Nesses locais foram instalados bancos, floreiras, telefones públicos e mapas de localização das lojas.

Esse projeto de rua comercial possui desenho de mobiliário urbano próprio, incluindo relógios, lixeiras, bancos e mapa de localização das lojas. As lixeiras estão colocadas de forma adequada, permitindo o acesso universal, pois a altura do orifício está a aproximadamente $1,10 \mathrm{~m}$ do piso, de tal forma que o cadeirante consegue se aproximar e utilizar a lixeira. A colocação destas não apresenta problemas quanto à detecção por bengala de pessoas com deficiência visual, porque essas podem detectar objetos suspensos a até $60 \mathrm{~cm}$ do piso, como é o caso.
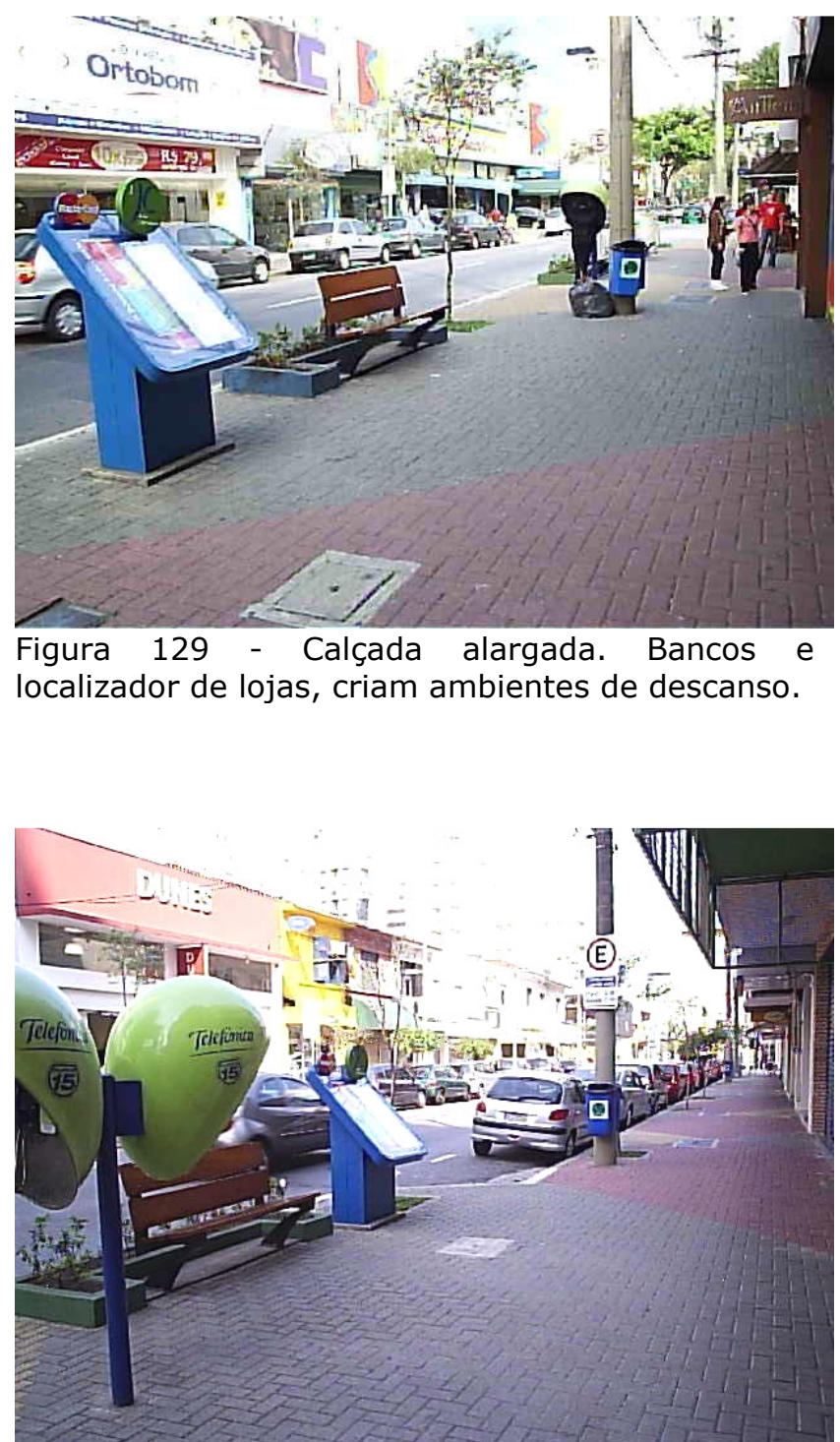

Figura 130 - Mobiliário urbano na calçada da Rua João Cachoeira. 
Os mapas de localização das lojas, semelhantes aos usados em shopping centers, estão situados ao longo do caminho, em cada uma das "ilhas de descanso". Esses mapas possuem fonte e tamanho das letras legíveis, porém falta uma alternativa de localização para pessoas com deficiência visual. Para essas pessoas poderia ser adotado sistema sonoro ou mapa tátil, com informações em relevo e texto em Braille. Seria importante também, o treinamento dos seguranças presentes ao longo da rua, para que soubessem como orientar e lidar com pessoas com deficiência.

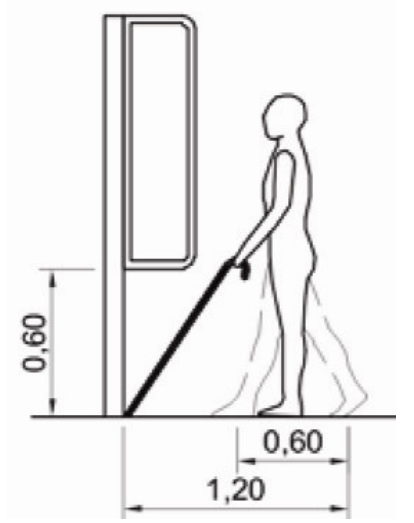

NBR 9050/2004 - detecção de objetos suspensos pelas bengalas.

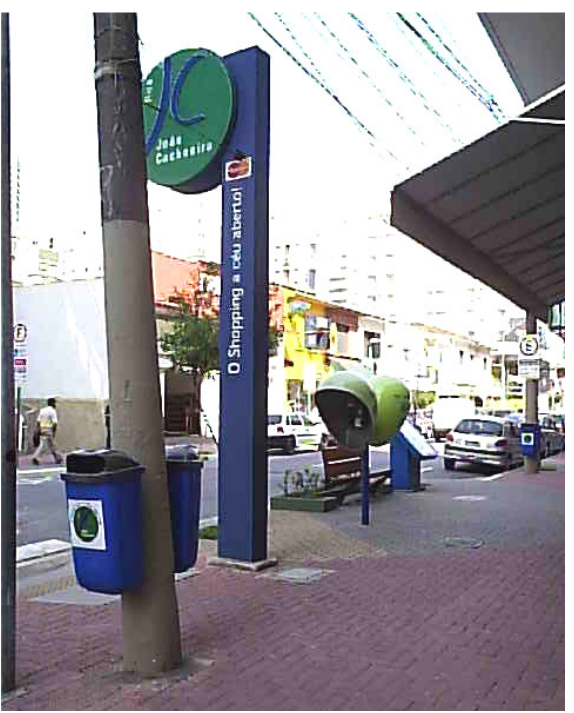

Figura 132 - "Ilhas de descanso" e mobiliário urbano próprio.

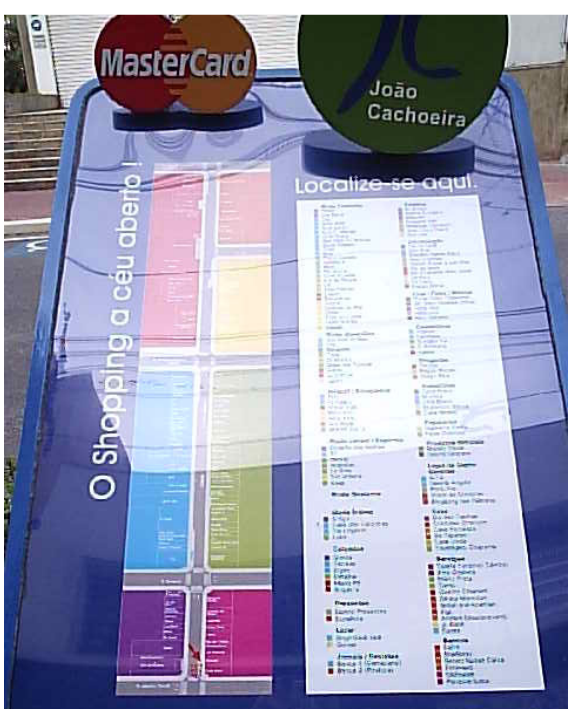

Figura 131 - Detalhe de localizador de loias. 
Na Rua João Cachoeira, junto aos bancos de madeira existem floreiras que rodeiam os assentos e impedem que pessoas em cadeiras de rodas se posicionem junto a outras pessoas que estejam sentadas. Para este caso, deveriam ser deixados espaços laterais de no mínimo 0,80m, como determina a NBR9050/2004. Vale ressaltar que a solução utilizada para manter essa área de descanso fora da circulação é importante, pois dessa forma não causa impedimentos, nem proporciona desvios no caminho do pedestre.

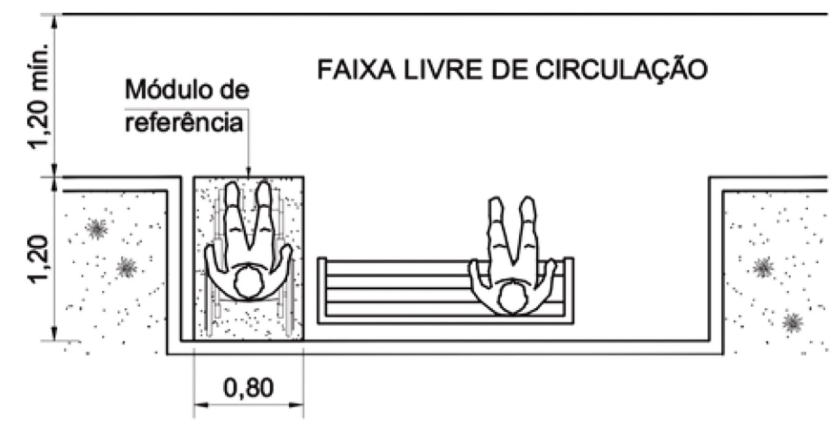

Figura 133 - NBR9050/2004 - assentos fixos

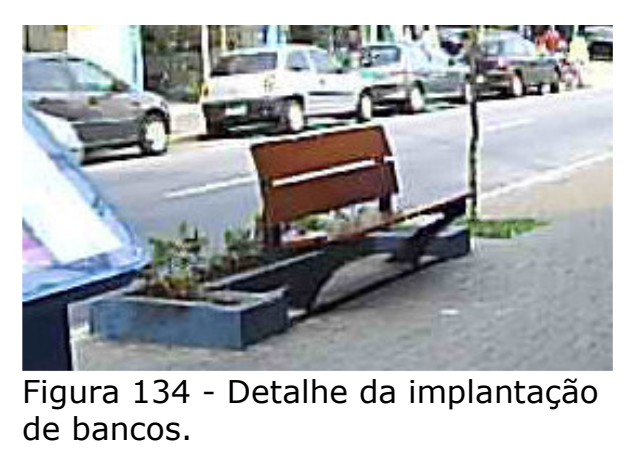


Os telefones públicos, os "orelhões", na Rua João Cachoeira também representam problemas para pessoas com deficiência visual, pois sua base não corresponde ao volume suspenso. A bengala detecta objetos que estão a até no máximo a $0,60 \mathrm{~m}$ do piso, e no caso dos "orelhões" o risco de colisão é grande.

Para sanar esse problema, deveria ser utilizado piso de alerta tátil próximo ao equipamento, como determina a NBR9050.

Em alguns casos, esses aparelhos estão localizados no que deveria ser a faixa livre de circulação, obrigando o pedestre a desviar-se do caminho.
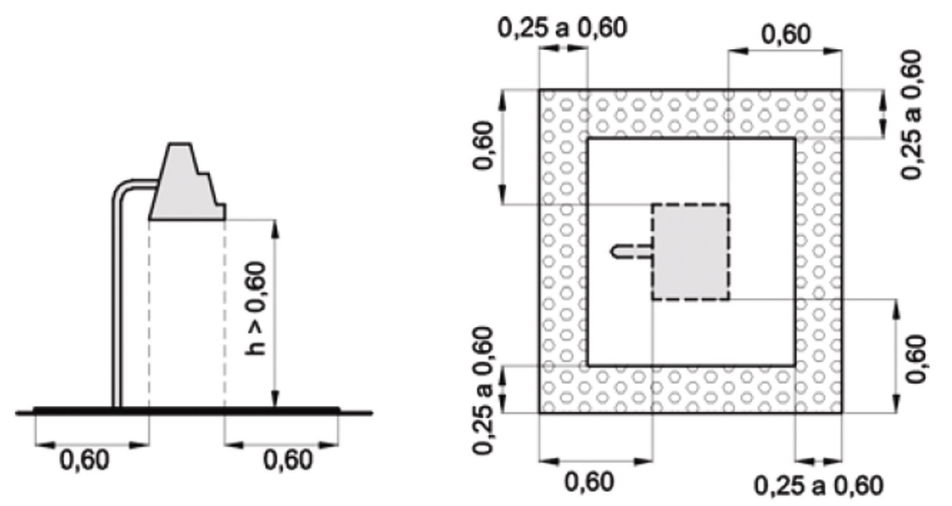

\section{Vista lateral}

Vista superior

Figura 136 - NBR 9050/2004 - sinalização tátil de alerta para obstáculos suspensos.

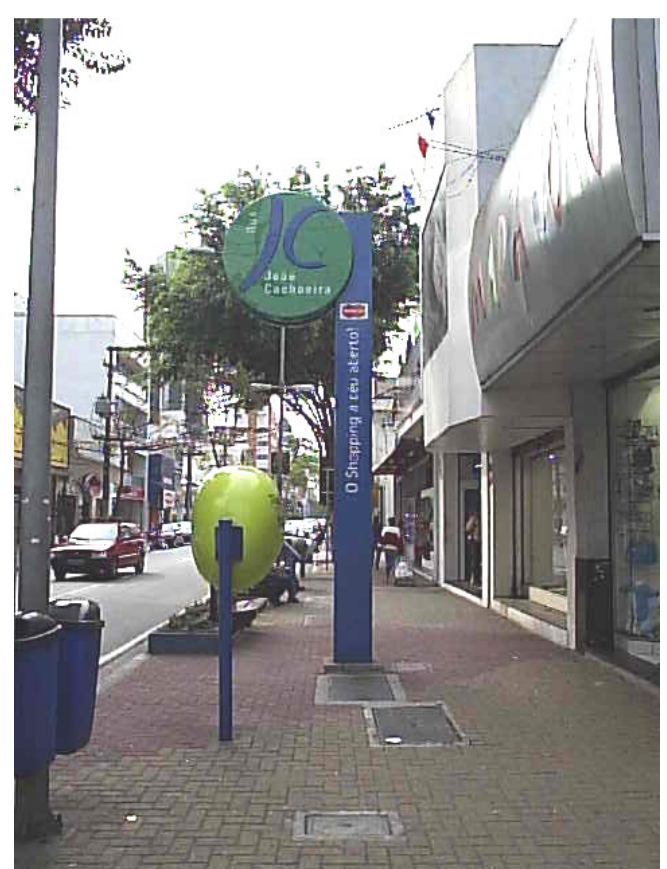

Figura 135 - Rua João Cachoeira - orelhão.

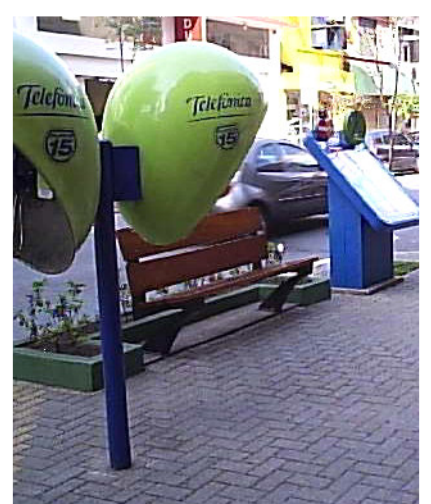

Figura 137 - Detalhe de orelhão, Rua João Cachoeira. 
Todas as rampas foram implantadas, corretamente, perpendiculares à faixa de pedestres e alinhadas com suas opostas correspondentes.

Os rebaixos, em concreto pré-moldado, estão devidamente sinalizados com pisos táteis de alerta, para orientação da pessoa com deficiência visual, como determina a NBR 9050/2004, e o contraste de cores e texturas, entre a rampa e o piso da calçada demarcam a travessia, auxiliando na localização.

Um problema que não foi resolvido, é a quantidade de postes e tampos de diversas concessionárias junto à esquina, dificultando a

leitura do local e a circulação, como pode ser visto nas fotos ao lado.

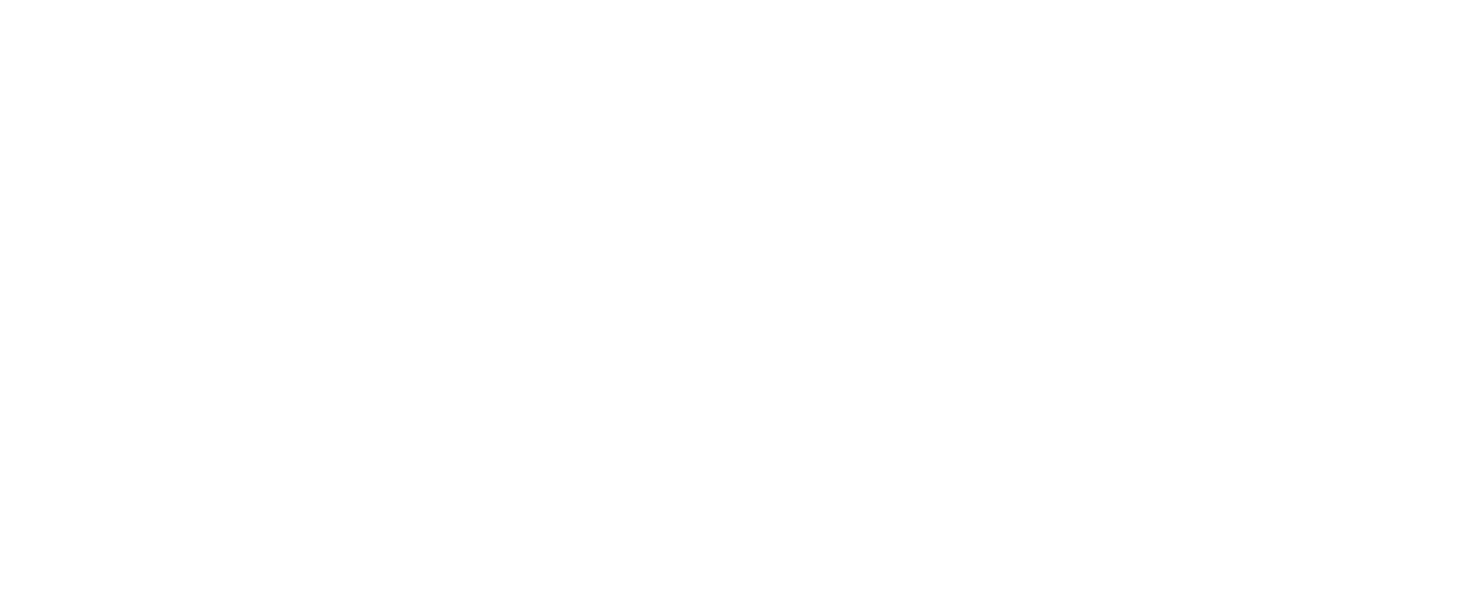

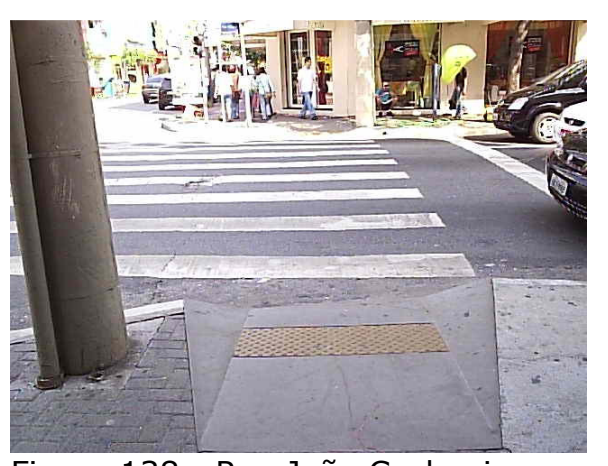

Figura 138 - Rua João Cachoeira, esquina com a Rua Tabapuã.

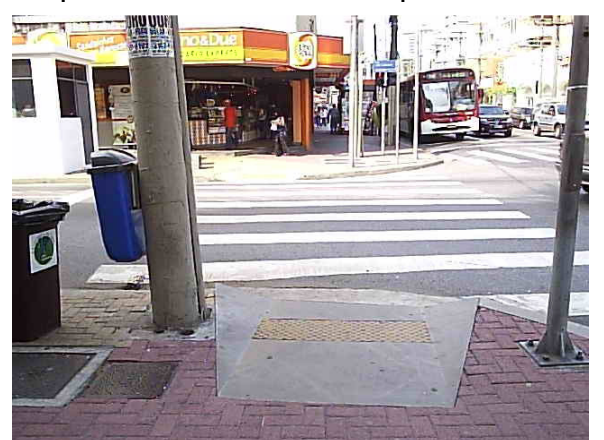

Figura 139 - Rua João Cachoeira, esquina com a Rua Joaquim Floriano.

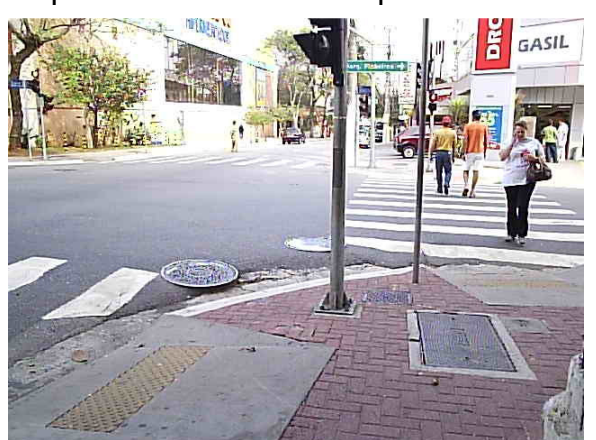

Figura 140 - Rua João Cachoeira, esquina com a Rua Leopoldo C. de Magalhães Jr.. 


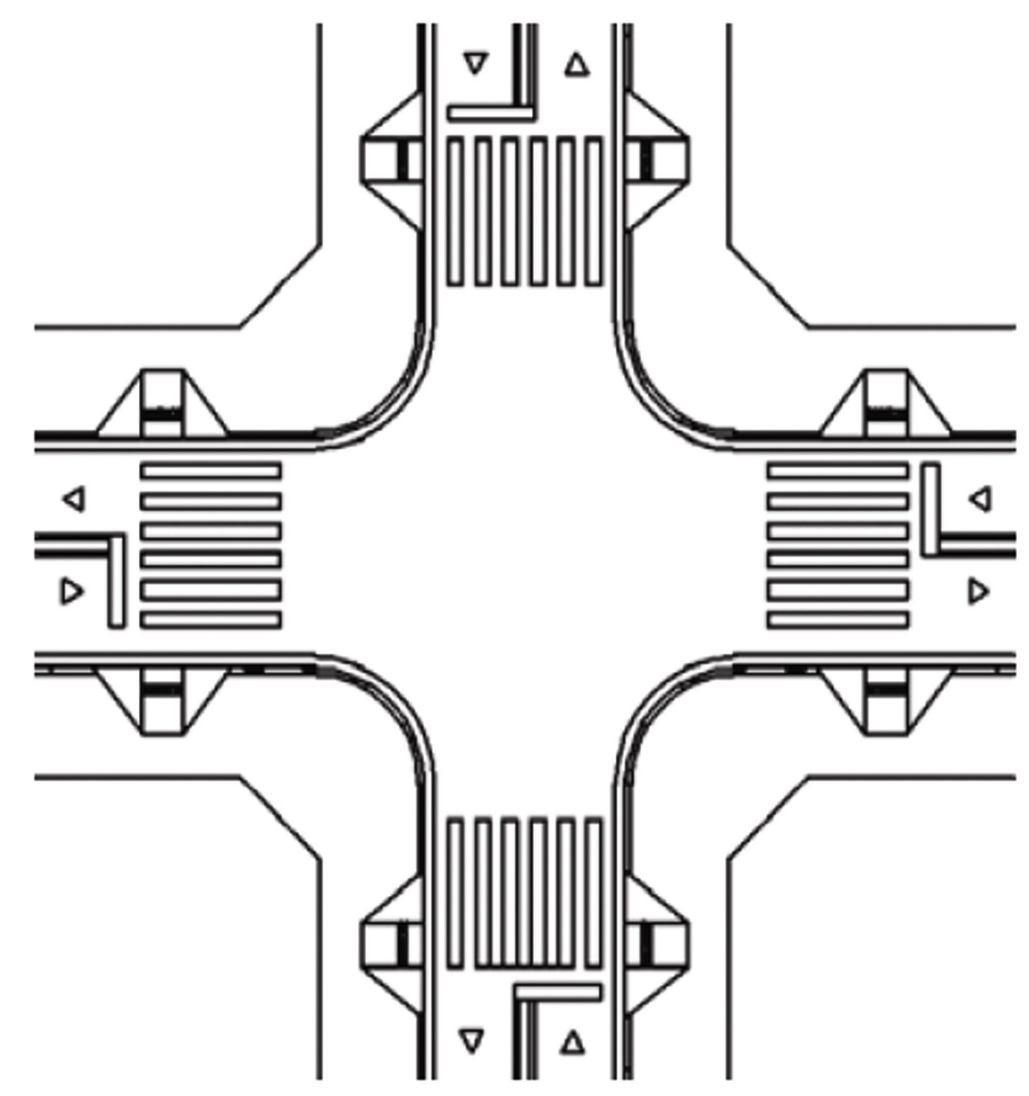

Figura 142 - NBR9050/2004 - rebaixamento de esquinas.

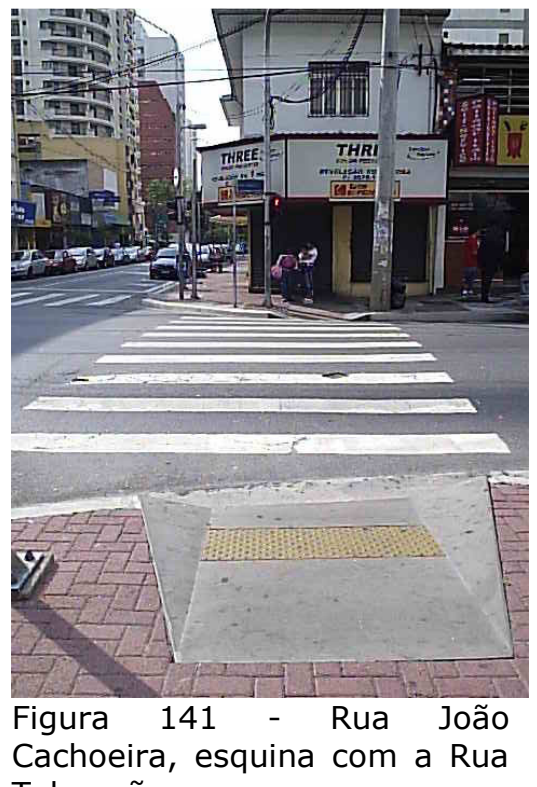

Cachoeira, esquina com a Rua

Tabapuã.

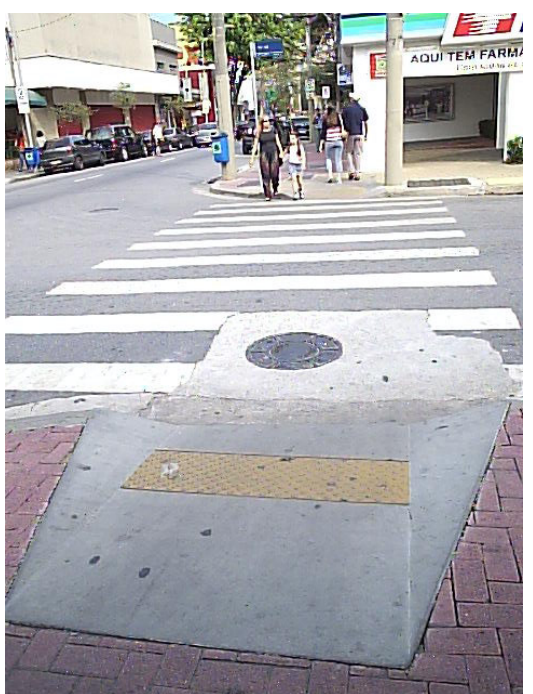

Figura 143 - Rua João Cachoeira, esquina com a Rua Iaiá. 
Embora exista a separação de usos no passeio considerando a faixa de serviço, a faixa livre e a faixa de acesso do lote, os tampos das concessionárias, no piso, não respeitaram essa orientação, pois estão localizados na faixa livre, quando deveriam estar na de serviços.

O desenho do piso não demarca as faixas do passeio, como determina o Programa Passeio Livre da Prefeitura.

Em 2003, quando ocorreu a reforma da calçada, os parâmetros do Decreto 45.904 ainda não estavam definidos, pois entrou em vigor em 2005. Talvez por isso, alguns dos aspectos observados, anteriormente, tenham ocorrido.

Alguns vendedores ambulantes (camelôs) permanecem nas calçadas. Na foto inferior, o camelô está na faixa de serviço, e embora estreite o passeio, não chega a prejudicar o fluxo, significativamente.

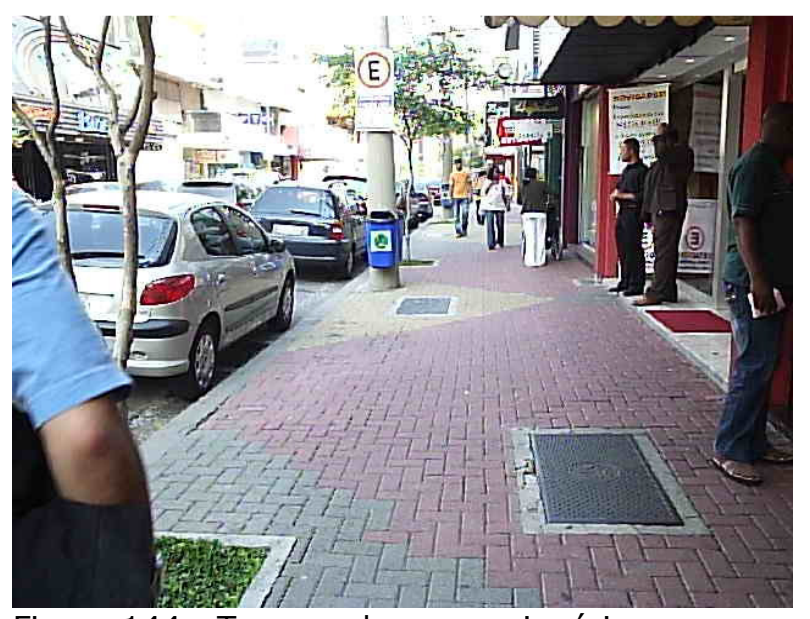

Figura 144 - Tampos de concessionárias na calçada da Rua João Cachoeira.

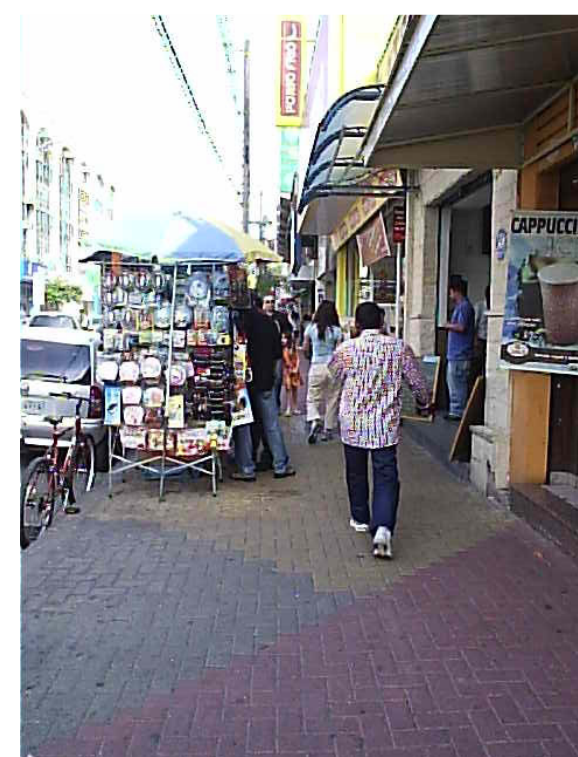

Figura 145 - Vendedor ambulante estabelecido na faixa de serviços. 
Na Rua João Cachoeira, a faixa de acesso do lote é utilizada por determinados estabelecimentos para colocar mostruários ou balcões. Essa ocupação respeita as condições determinadas pela Prefeitura, sem invadir a faixa livre de circulação.

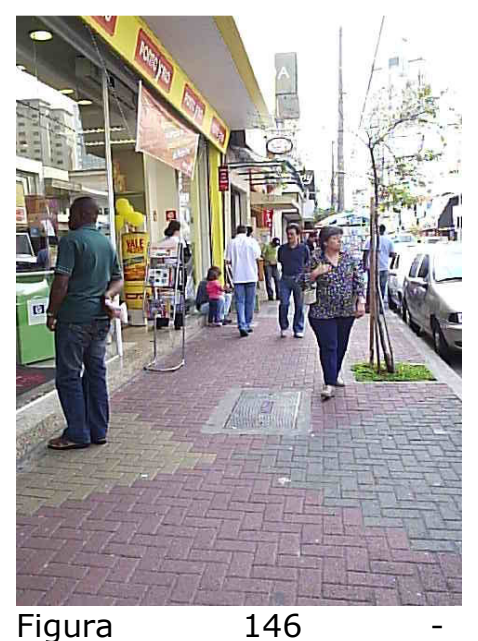

Estabelecimento, na Rua

João Cachoeira, utiliza a

faixa de acesso do lote para colocar mostruário.

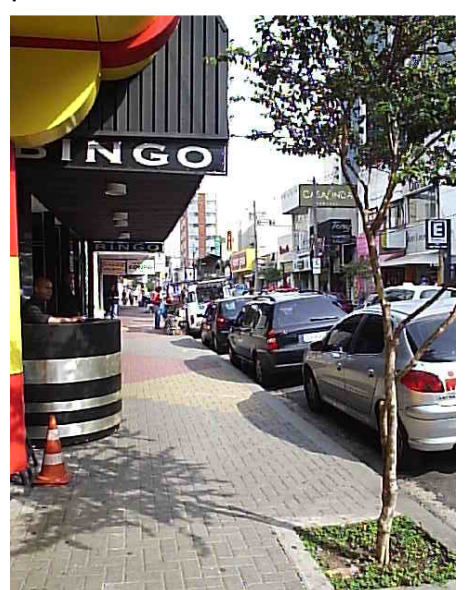

Figura 147 - Bingo, na Rua João Cachoeira, utiliza a faixa de acesso do lote para colocar mobiliário. 
O estabelecimento mostrado, na foto superior, dispõe suas mesas na calçada apenas na faixa de acesso, respeitando a faixa livre, conforme determina o Programa Passeio Livre.

Na foto inferior, o ponto de táxi não atrapalha a circulação da calçada, mas também não propicia ambiente para acomodar os taxistas e os passageiros que os aguardam.

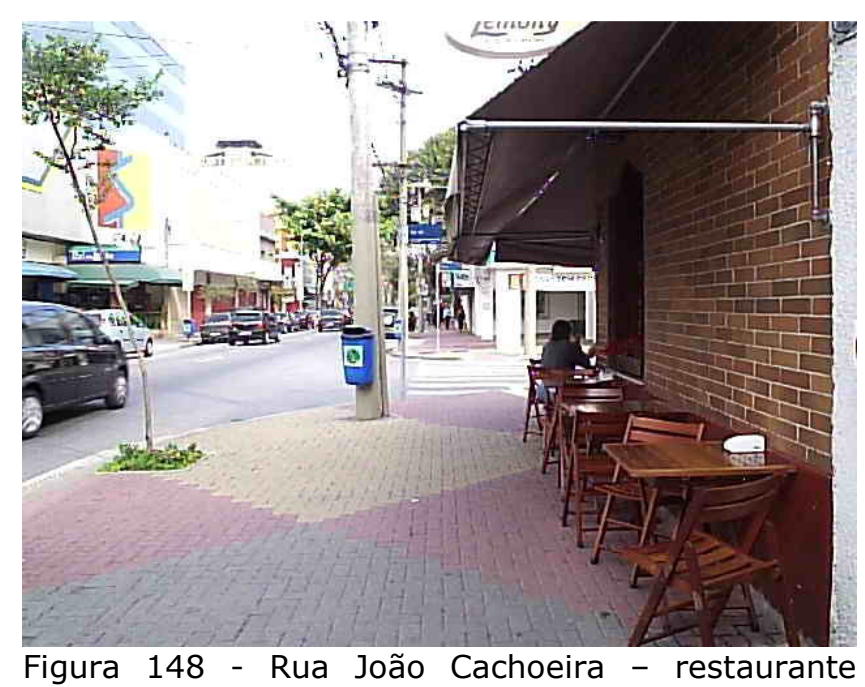

coloca mesas na faixa de acesso ao lote.

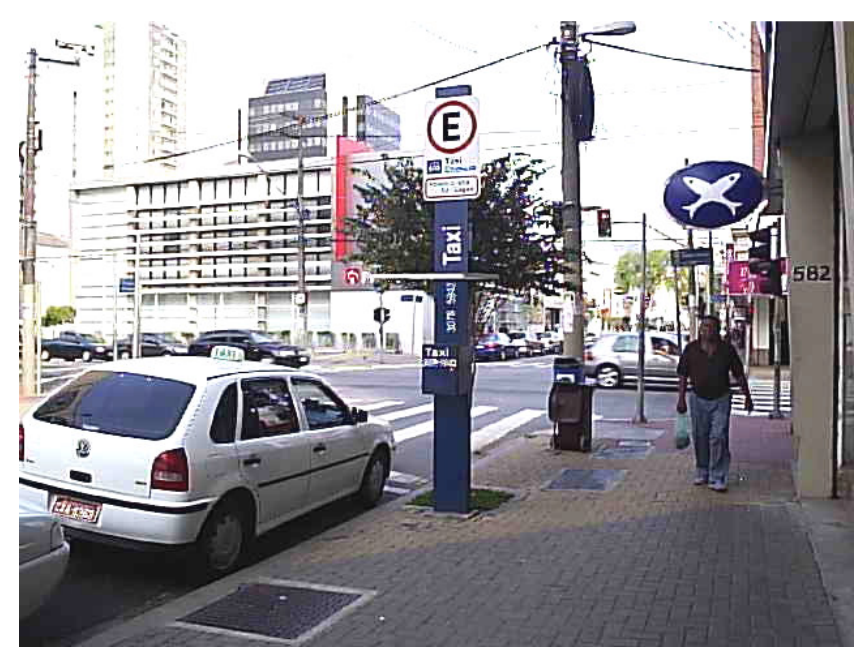

Figura 149 - Ponto de taxi na Rua João Cachoeira. 
Próxima à última esquina do projeto (Rua Leopoldo Couto Magalhães - próximo ao Hipermercado Extra), a banca de jornal, da foto superior, ocupa metade do passeio dificultando a passagem na calçada. Segundo o Decreto 45.904 de 2005, a banca poderia ocupar apenas a faixa de serviço.

Pode-se verificar também, na mesma foto, a colocação de publicidade ocupando a faixa de serviço e não a de acesso onde é permitida.

Na foto inferior, a banca de jornal, próxima à esquina com a Rua Tabapuã, foi implantada de forma correta, ocupando apenas a faixa de serviço, o quê permite o fluxo livre dos pedestres.

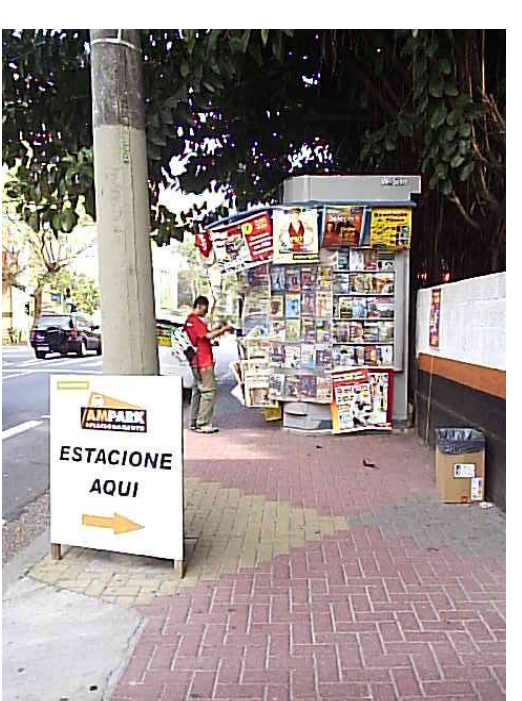

Figura 150 - Banca de Jornal na faixa de acesso ao lote, ocupando parte da faixa livre.

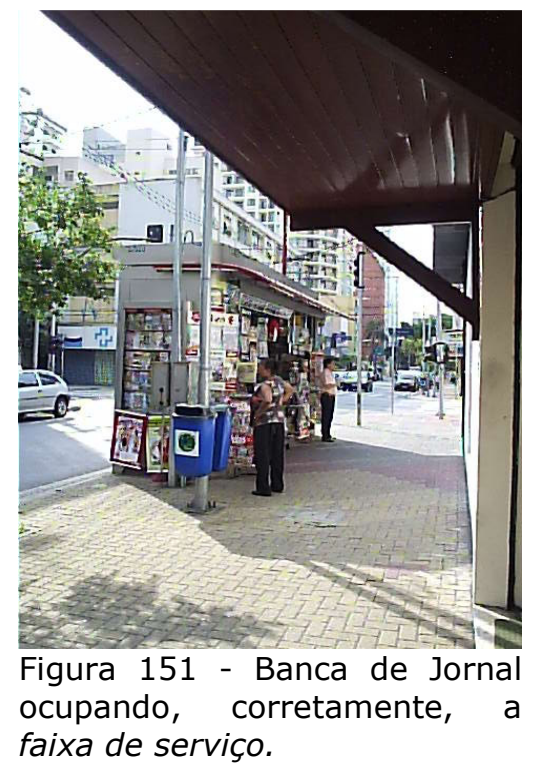


Na reforma das calçadas da Rua João Cachoeira, as entradas das lojas não se adequaram à acessibilidade. Mesmo a rua sendo plana, muitos estabelecimentos ainda continuam com degraus no acesso. Para dentro do lote, a Prefeitura não pode intervir. Essa adequação deveria partir do respeito à legislação e da consciência cidadã dos lojistas.

Alguns estabelecimentos possuem estacionamento que ocupa o passeio, dificultando a circulação de pedestres. Na foto inferior, a loja poderia utilizar apenas a faixa de acesso, porém está invadindo a faixa livre.

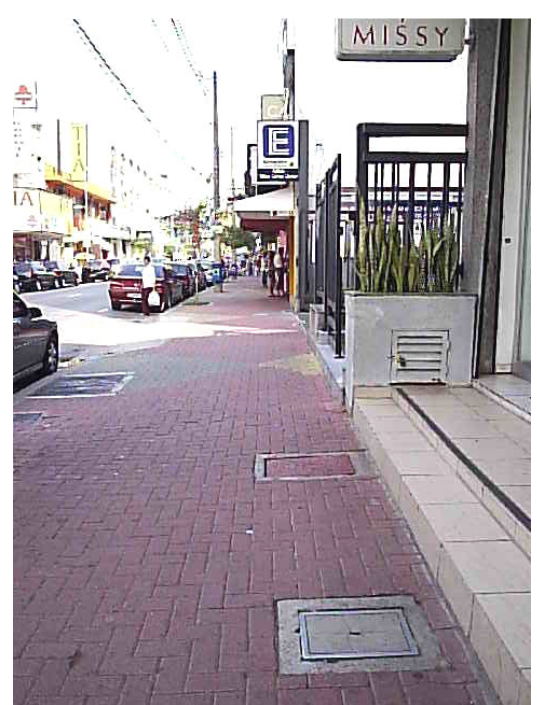

Figura 153 - Estabelecimentos na Rua João Cachoeira não se adequaram a acessibilidade.

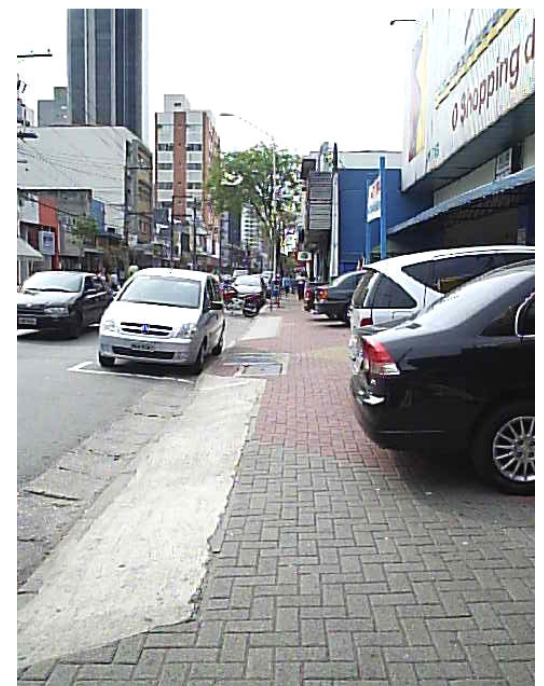

Figura 152 - Carros estacionado invadem a faixa livre. 
Ao longo da via existem vagas para veículos de PCDs. Há alargamento da calçada na parte da frente da vaga, permitindo melhor acomodação do veículo (vide foto superior).

Em algumas das vagas encontradas, existem problemas de interferências na calçada, impedindo que a porta do carro seja aberta. Como, por exemplo, a localização de árvores ou sinalização vertical da vaga ao lado do espaço de abertura dessas portas (vide fotos ao lado).

Na foto inferior, há um flagrante de barreira "atitudinal". Uma motocicleta ocupa parte da vaga, dificultando o estacionamento de veículos de PCDs.

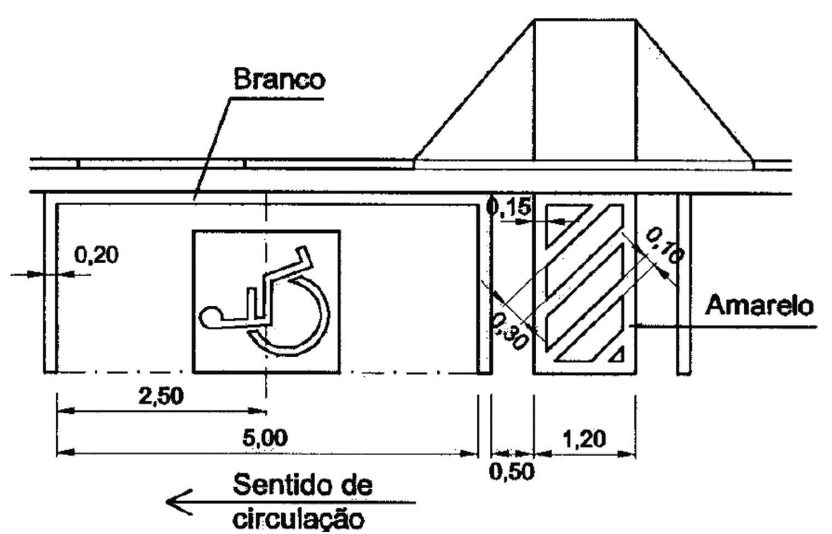

Figura 156 - NBR 9050/2004 - configuração de vagas para PCDs

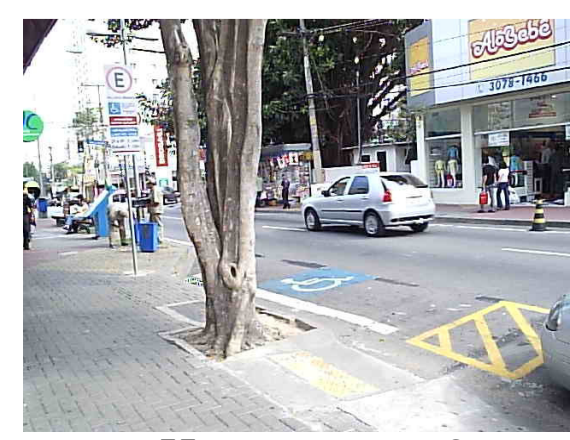

Figura 155 - Vaga para PCD, Rua João Cachoeira. Arvore impedindo abertura de porta dos automóveis.

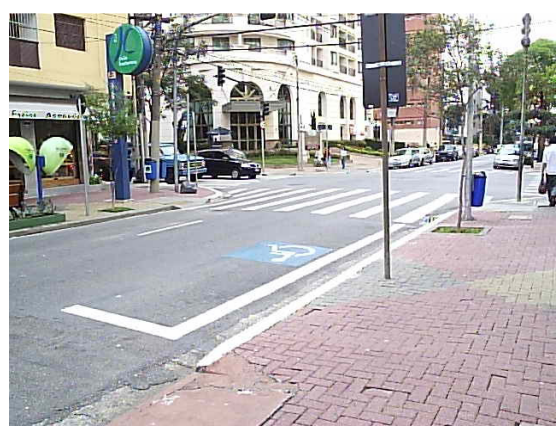

Figura 154 - Vaga para PCD, Rua João Cachoeira. Sinalização vertical impedindo abertura de norta dos automóveis.

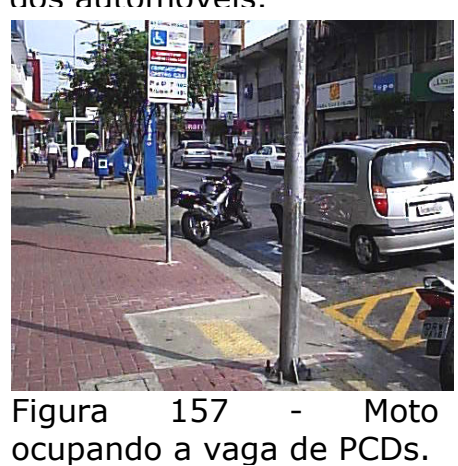

Figura 157 - Moto
ocupando a vaga de PCDs.

Página 178 
A configuração na imagem, ao lado, constitui exemplo de situação mais segura para acomodação de cadeirantes, no ato da descida do veículo, pois a PCD pode fazer a manobra da cadeira de rodas em local protegido do fluxo da via.

No final do trecho reformado, cruzamento da Rua João Cachoeira com a Rua Leopoldo Couto Magalhães Jr. (foto inferior), pode-se ver o contraste entre a área refeita e a não atingida pelo projeto. Mesmo sendo largo, o passeio da foto possui diversos problemas de manutenção de piso, como buracos e saliências.

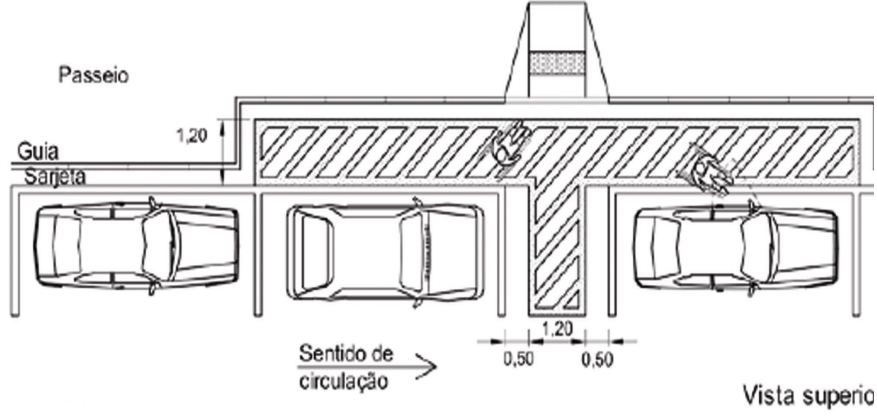

Figura 158 - NBR 9050/2004 - vagas estacionamento em baias avançadas no passeio.

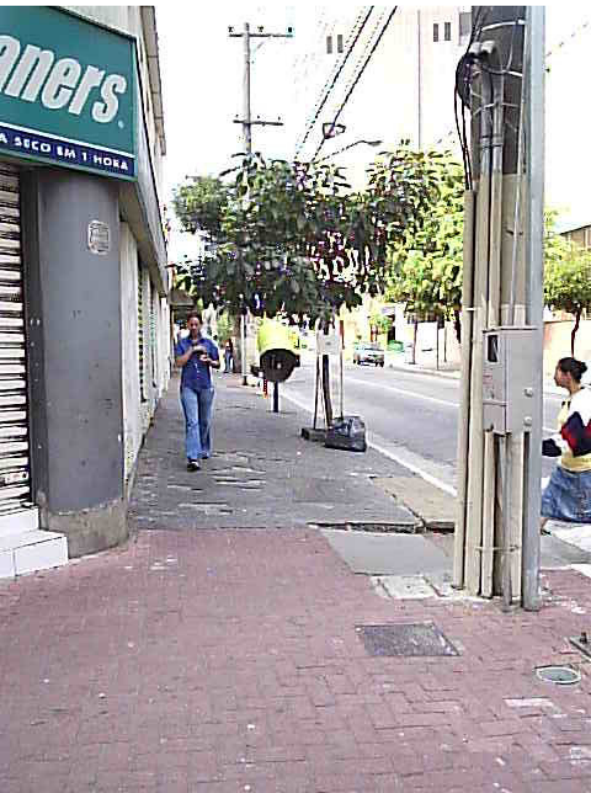

Figura 159 - Limite das intervenções Rua Leopoldo Couto Magalhães Junior. 


\section{Considerações finais - Rua João Cachoeira}

O projeto constitui a primeira intervenção em calçadas decorrente do Programa de Ruas Comerciais, iniciativa que partiu dos próprios comerciantes, segundo informações da Prefeitura.

O mobiliário desenhado para o local está colocado de forma a não atrapalhar o caminhamento do pedestre e propicia descanso para os visitantes.

Boa parte dos vendedores ambulantes que se utilizavam do espaço das calçadas foi retirada, restando apenas alguns poucos, que não têm causado grandes impactos no fluxo de pedestres. A região está inteiramente vigiada por seguranças, como os dos shopping centers, que são mantidos pelos próprios lojistas.

O piso é de blocos de concreto intertravado e desenho não demarca as faixas de uso do passeio, como determina o Programa Passeio Livre, mas de modo geral têm seus usos respeitados.

As rampas de acesso para PCDs, nas calçadas, são de concreto pré-moldado e a topografia da rua, que é quase plana, favorece ações em prol da acessibilidade. 
A fiação aérea não foi enterrada e existem inúmeros postes, tampos e obstáculos junto às esquinas, dificultando a visualização da travessia e a circulação.

As entradas e saídas dos estacionamentos não possuem alertas sonoros, assim como os semáforos. Essa sinalização é muito importante para as pessoas com deficiência visual, para alertá-las sobre a circulação dos veículos e a possibilidade de travessias.

O mobiliário urbano não foi alvo de preocupação específica sobre questões de acessibilidade. Os orelhões não possuem sinalização tátil de alerta no piso, o qual evitaria a colisão pessoas com deficiência visual. Os bancos não oferecem a possibilidade de que cadeirantes possam manter-se ao lado de outras pessoas ali sentadas.

A preocupação dos lojistas foi com a melhoria das calçadas, para que houvesse incremento nas vendas, pois espaços agradáveis atraem o público. Segundo Felippe Naufel, presidente da Associação de Lojistas da João Cachoeira: "quanto mais agradável for o ambiente, melhor para o comprador", pois "O cliente tem de se sentir 
à vontade para fazer suas compras". E de fato, de acordo com a Prefeitura, os ganhos cresceram $20 \%$ após a reforma.

No entanto, o público, considerado pela reforma, não envolveu de fato as pessoas com deficiência. Isso fica claro ao observar que as lojas não se adaptaram à entrada de cadeirantes. Percebe-se que ao longo do percurso não existiu preocupação em orientar a pessoa com deficiência visual, por exemplo, sobre localização das lojas.

A acessibilidade foi alcançada ao longo do percurso da Rua João Cachoeira, mesmo sendo foco secundário da prática da reforma das calçadas. A circulação acontece de forma linear e contínua e a organização dos usos permitiu melhor apreensão do espaço, justificando socialmente essa obra. 


\section{Calçadas - Comentário final.}

Todas as ruas estudadas, que passaram por reformas de calçadas, tiveram grandes ganhos com a acessibilidade. A padronização de seus pisos eliminou a existência de degraus, tão comuns à cidade e suprimiu os problemas entre vegetação e piso que, em alguns casos, destroem as calçadas e estreitam a passagem.

Os pisos estão em excelente estado de conservação e as rampas foram instaladas em quase todas as travessias.

Durante as reformas, não foi detectado plano de rotas alternativas, que fossem seguras e acessíveis a todos, especialmente às PCDs. Isso é uma falha a ser considerada, pois gera riscos de acidentes e impede, mesmo que temporariamente, a circulação de pessoas com mobilidade reduzida, nesses locais em reforma.

As calçadas analisadas, por serem obras realizadas pelo Poder Público ou sob a orientação deste, deveriam ser as primeiras a demonstrar preocupação em criar rotas alternativas, seguras, para o pedestre, durante as obras. Além disso, o Poder Público deveria exigir 
que todas as obras, que fizessem intervenções sobre o passeio, tivessem o mesmo cuidado.

Observa-se que, em todas as reformas, a eficiência do resultado, referente às questões de acessibilidade, está ligada diretamente à existência de detalhamento de projeto. Para a efetiva qualidade na circulação de PCDs, é imprescindível que toda a obra seja cuidadosamente executada e, neste quesito, o papel do projeto intensamente detalhado é fundamental, pois $1 \mathrm{~cm}$ pode fazer a diferença entre a barreira e a acessibilidade.

As reformas, de modo geral, não tiveram apenas caráter legalista, ou seja, não tiveram apenas a intenção de cumprir a legislação, mas trouxeram ganhos de qualidade para os espaços em que fazem parte.

As barreiras ocasionadas pelas atitudes da população como um todo, são bastante freqüentes e refletem uma situação em que o individual prevalece sobre o coletivo. A falta de consciência cidadã não é um problema que atinja exclusivamente pessoas com deficiência, pois atinge a todas as pessoas. As pessoas PCDs são as que mais sofrem com essas atitudes, pois acabam impedidas de exercer um direito garantido pela Constituição Federal, o de "ir e vir". 


\section{Estudo de caso - Playcenter}

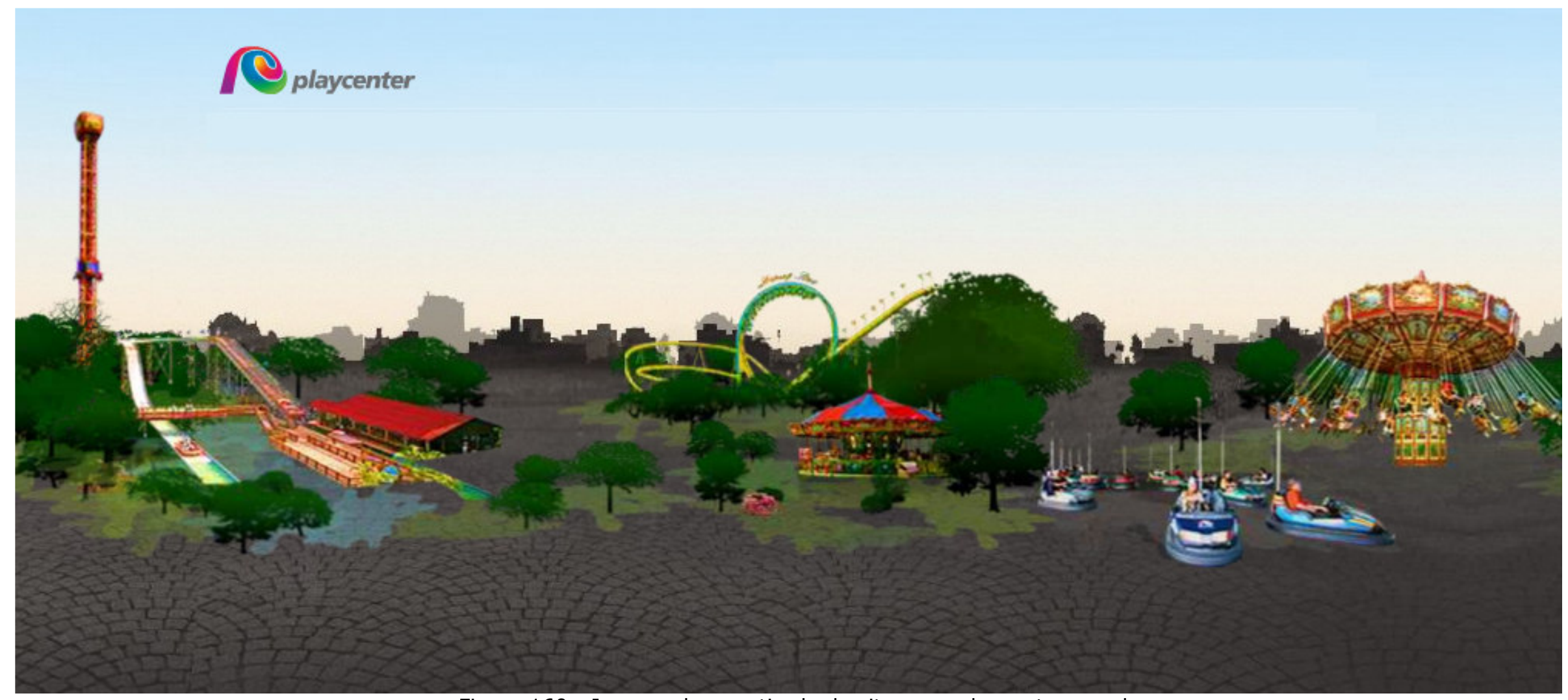

Figura 160 - Imagem base retirada do site www.playcenter.com.br 


\section{Apresentação - Justificativa de escolha}

O Parque Playcenter foi objeto de escolha de análise do presente trabalho, porque é um dos maiores empreendimentos privado, de lazer ao ar livre, na cidade de São Paulo.

Todos os empreendimentos de acesso coletivo devem atender ao público sem discriminação, em especial, às pessoas com deficiências. No caso específico do Playcenter, essa necessidade torna-se ainda mais dramática, se considerada a faixa etária dos freqüentadores, que são, em sua maioria, crianças e adolescentes.

Como dito anteriormente, a maior parte do público é jovem. A faixa etária de maior freqüência varia de 12 a 25 anos de idade. 0 grupo "família" visita o local nos finais de semana e idosos raramente, mas também vão ao parque acompanhando os netos, segundo a empresa. 


\section{Metodologia do estudo de caso - Playcenter.}

A delimitação física da área de estudo, mais aprofundada, corresponde aos limites do Parque, onde estão as atrações abertas ao público, ou seja, não foram consideradas as áreas pertencentes aos funcionários e aos serviços ligados ao parque.

O entorno imediato, com as calçadas e inter-relações com o transporte público, demarcaram os limites das análises de área externa. Para isso foi utilizado o Guia de Ruas de São Paulo, o Plano Regional da Subprefeitura da Lapa, fotos aéreas e roteiros fotográficos realizados em visitas.

A primeira etapa consistiu em contatar a direção do Parque e fazer as primeiras consultas referentes aos dados históricos relevantes, números de funcionários, quantidades de atrações, dados sobre a visitação do público e obtenção de material gráfico (fotos e plantas).

As consultas bibliográficas que mais auxiliaram diretamente neste estudo foram a NBR 9050/2004, a legislação sobre acessibilidade e calçadas, a Cartilha do Programa Municipal Passeio 
Paisagem.

A primeira visita ao local foi realizada em companhia do responsável pela manutenção do Parque, Sr. Hércules Vergari, que acompanhou e forneceu explicações ao longo do percurso. Essa visita resultou em roteiro fotográfico preliminar.

Balizada pela legislação e pela Norma Brasileira de Acessibilidade, foram feitas as primeiras análises do local. Após os estudos preliminares, os primeiros resultados foram apresentados aos dirigentes do Parque, para discussões e debates sobre os pontos principais.

O Playcenter forneceu o Manual Técnico - Parques de Diversão, que apresenta algumas limitações de uso, para algumas condições físicas, mentais e sensoriais dos usuários, impostas por determinados tipos de brinquedos. Quanto aos parâmetros de acessibilidade, referentes ao espaço físico, esses estão completamente equivocados, pois o Manual baseou-se em versão ultrapassada da NBR9050/2004. 
O novo roteiro fotográfico realizado após as conversas e análise do material gráfico, aprofundou os estudos das questões de acessibilidade, fundamentadas também em bibliografia.

Após a primeira fase de pesquisas no Parque, importantes diretrizes voltadas às pesquisas em Desenho Universal e estudos da paisagem, exigiram retorno à bibliografia para complementar as bases teóricas.

Análises das questões urbanísticas foram incorporadas à dissertação, com apresentações gráficas que auxiliaram na compreensão e na localização da área de estudo.

Os meios de transporte que atendem ao Parque foram verificados in loco, através do Guia de Ruas de São Paulo, Plano Regional da Subprefeitura da Lapa e do site do Metrô na internet (http://www.metro.sp.gov.br/servicos/terminais/barrafunda/barra.sh tml).

Questionários não foram aplicados ao público freqüentador do Parque, por problemas de viabilidade em sua execução. Para que fossem aplicados, seriam necessários mais tempo e mais entrevistadores, para chegar a um número de respostas 
estatisticamente confiável. Porém, por considerar de fundamental importância a opinião do usuário, neste estudo, foi realizada visita com uma cadeirante ao Parque.

Para o walkthrough foi predeterminado um pequeno roteiro a ser seguido, porém a cadeirante ficou livre para escolher em quais atrações participaria.

Ao ingressar no parque, foi feita uma breve análise das condições "físicas" da cadeirante, por parte da atendente do Setor de Informações, que preencheu um formulário padrão, indicando em quais atrações a PCD não poderia brincar. Neste caso específico foram vetados o Skycoaster, Boomerang e Arvorismo (vide fotos ao lado).

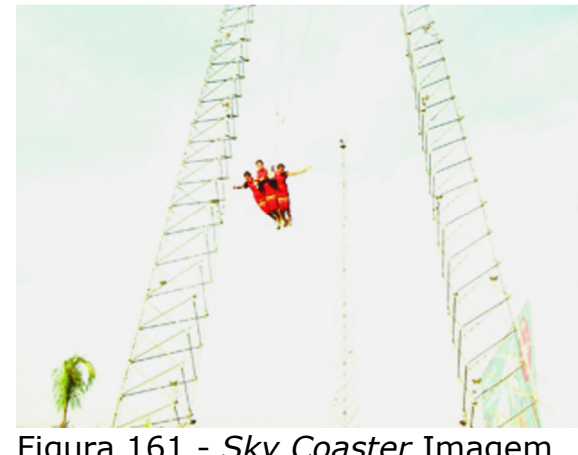

Figura 161 - Sky Coaster Imagem disponível em:

www.playcenter.com.br

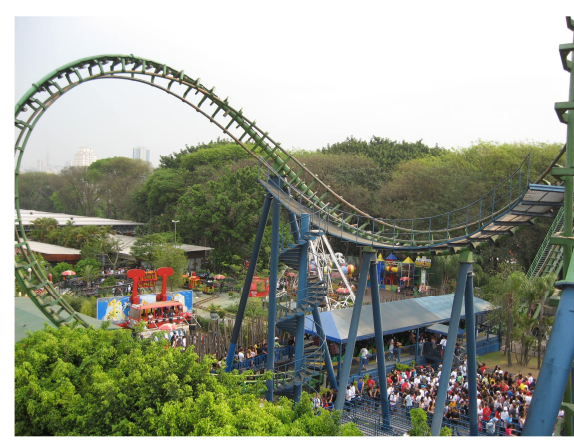

Figura 162 - Boomerang

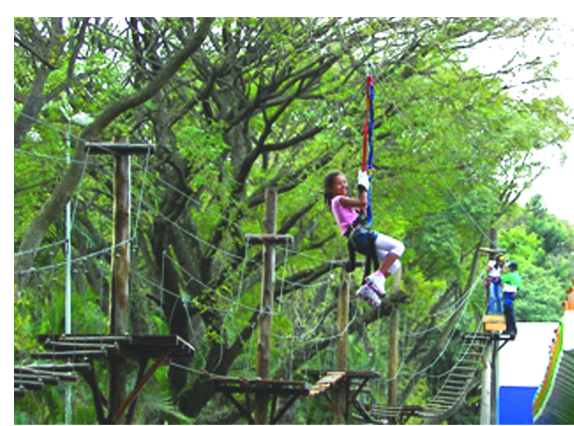

Figura 163 - Arvorismo Imagem

disponível em:

www.playcenter.com.br 
As atrações visitadas foram: Barca Viking, Roda Gigante, Magic Motion, Wind Storm e Wave Swinger.

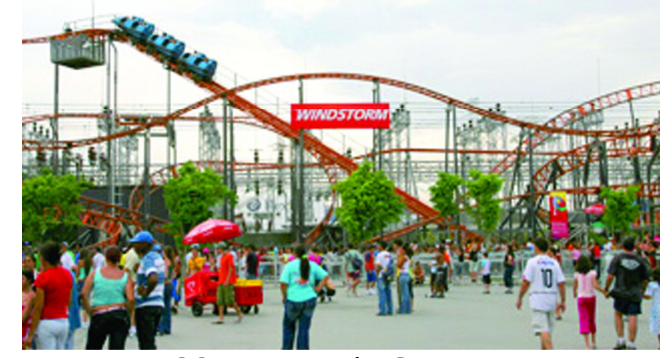

Figura 166 - Wind Storm. Imagem disponível em: www.playcenter.com.br

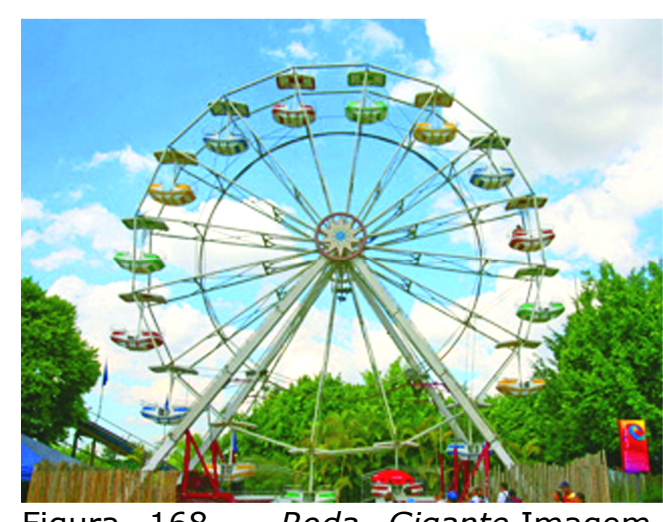

Figura 168 - Roda Gigante.Imagem disponível em: www.playcenter.com.br

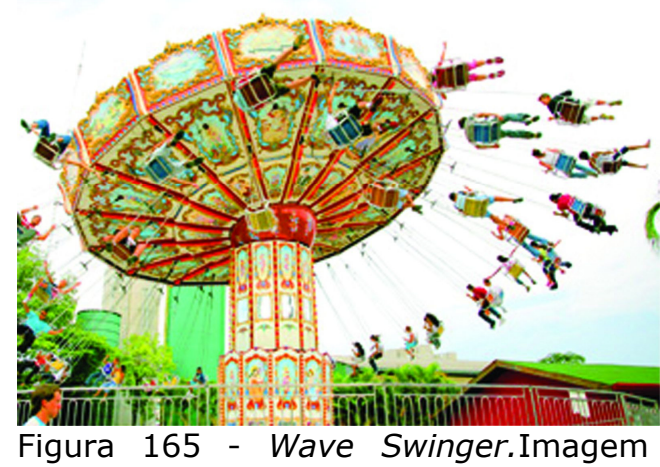
disponível em: www.playcenter.com.br

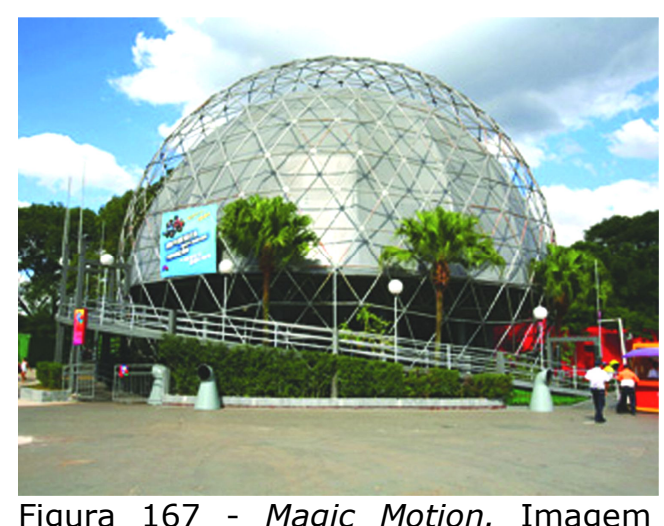

disponível em:

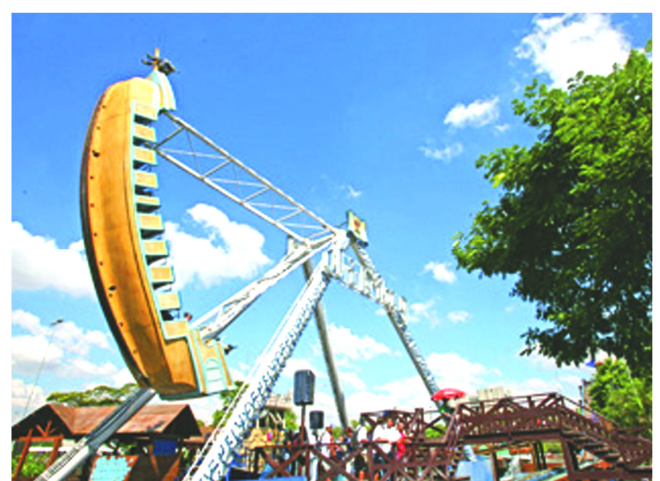

Figura 164 - Barca Viking. Imagem disponível em: www.playcenter.com.br 
Na data da visita, estavam acontecendo as Noites do Terror, sendo assim, o roteiro foi repetido à noite, porém sem entrar nos brinquedos.

Visitaram-se os ambientes preparados teatralmente para as "brincadeiras" e durante esse percurso noturno, não foram feitas fotos, pois necessitou-se de maiores cuidados com a cadeirante e porque a pesquisadora preferiu guiá-la para sentir as dificuldades do terreno.

A etapa final consistiu em reunir todas as análises e informações, conversar com especialistas da área de paisagem e de acessibilidade, para então debater as questões mais relevantes e apresentá-las na dissertação.

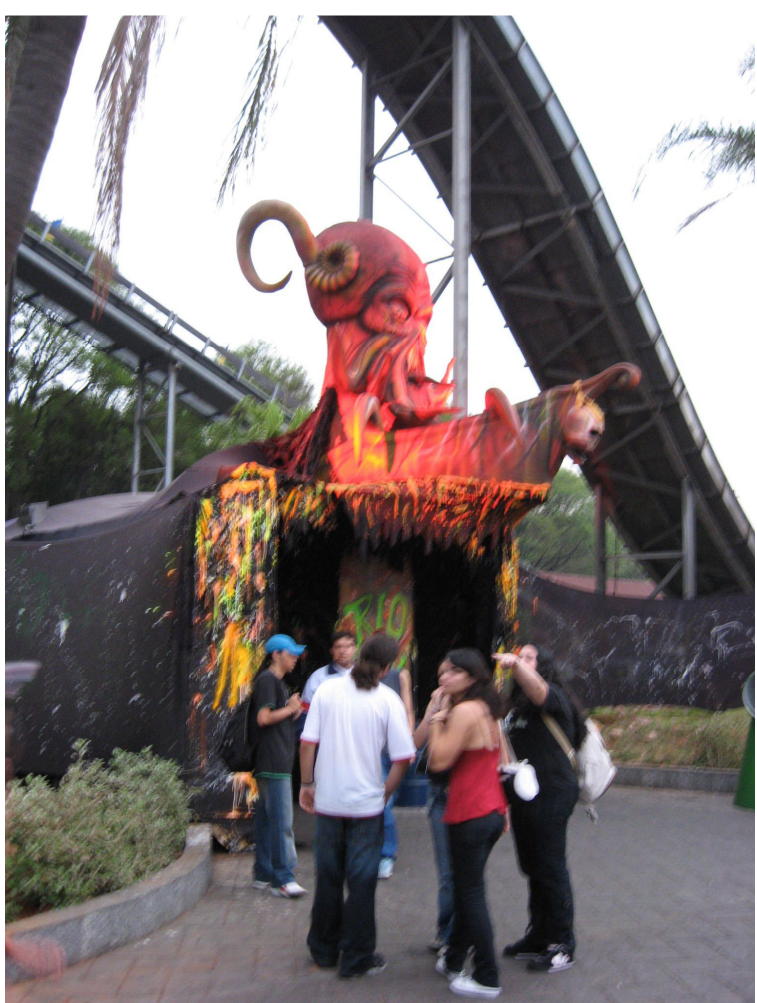

Figura 169 - Instalação das Noites do Terror Playcenter. 


\section{Histórico do Parque}

Fundado em 1973, por grupo de empresários, que conheciam parques de diversões em grandes cidades dos Estados Unidos e da Europa, o Playcenter foi montado na Marginal do Rio Tietê, originalmente com 20 atrações em 50 mil metros quadrados. Ao longo de sua história o parque já recebeu mais de 60 milhões de visitantes, segundo dados do próprio Parque.

Com o passar do tempo o Playcenter ampliou o número de atrações e instalações, chegando ao total de 35 , tornando-se atração turística da cidade de São Paulo, com visitantes de todo o Brasil.

No aspecto social, o Playcenter possui projetos educativos que, somente em 2005, receberam gratuitamente cerca de 30 mil pessoas.

Desde a sua inauguração é realizado o Dia Especial. Nessa ocasião, de forma gratuita, o parque é aberto exclusivamente para pessoas com deficiências. Os funcionários doam um dia de seu trabalho, e as instituições que lidam com as PCDs trazem os visitantes e se responsabilizam por eles durante todo o passeio. 
O parque chegou a ter 110 mil metros quadrados de área total, sendo todo o espaço alugado de terceiros. O Playcenter passou por uma reformulação, em pleno funcionamento, iniciada em 2003, que reduziu a área para 82 mil metros quadrados, segundo a administração da empresa. O processo de reforma do parque está ligado à queda de freqüência, observada entre os anos de 1998 e 2002. A partir de então, novos empreendimentos e conceitos foram implantados na tentativa de reverter esse quadro. A redução da área diminuiu os gastos com aluguel e otimizou os espaços, de tal forma que, os percursos tornaram-se menores, por conta da proximidade dos equipamentos.

Ao longo da reestruturação, as árvores existentes na área antiga, foram remanejadas e trazidas para a área atual, com a aprovação da Prefeitura. Para esses trabalhos há uma paisagista que assessora o Parque.

O ingresso, chamado Passaporte da Alegria, dá direito às trinta e uma atrações, sendo quatro outras pagas à parte, que são: Castelo dos Horrores, Crazy Party, Skycoaster e Arvorismo ${ }^{21}$.

21 Disponível em <http://www.playcenter.com.br>. Acesso em mar./2007 
De acordo com a Administração, o Parque é dimensionado para atender entre 7.000 e 8.000 pessoas de forma confortável.

O período de maior visitação são as férias de início de ano. Em março e abril, ocorre uma pequena queda e em maio, começam as excursões escolares, que elevam novamente o número de visitantes. Em julho existe, também, grande visitação em função das férias de meio de ano. De agosto a setembro, acontece o evento Noites do Terror que, no ano de 2006, em 56 dias, receberam aproximadamente 520 mil pessoas, segundo o Playcenter. 


\section{O Playcenter hoje}

As atrações do Parque são divididas em três categorias: infantis, familiares e radicais.

Atrações infantis:

- Barca Pirata;

- Carrossel Cavalinho;

- Convoy Racer;

- Dragon;

- Dumbinho;
- Fire Chief;

- Frog Hopper;

- Happy Moutain;

- Jumbo;

- Kid Play;

As atrações infantis estão localizadas de forma agrupada em local demarcado pelos limites do parque, resultando em espaço confortável e contido para crianças pequenas. A ambientação é agradável, com bastantes cores, vegetação e assentos para os acompanhantes dos pequenos visitantes. 
Atrações familiares:

- Arvorismo;

- Autopista;

- Barca Viking;
- Crazy Party;

- Polvo;

- Roda Gigante;
- Splash;

- Swing Dance;

- Waimea.

A ala das atrações familiares corresponde ao maior e principal setor do parque, localizada na entrada do conjunto. Apenas o Magic Motion encontra-se fora desse setor, pois está mais próximo ao chamado Setor 3, que é o das atrações radicais e eventos.

No percurso das atrações familiares, existem bancos para descanso, árvores e aspersores de água que amenizam o calor em dias de sol forte.

Atrações radicais:

- Boomerang;

- Double Shock;

- Skycoaster;

- Wind Storm.
- Castelo dos Horrores;

- Evolution;

- Turbo Drop;
- Cataclisma;

- Looping Star;

- Wave Swinger; 
Os brinquedos estão instalados ao longo do parque, sendo que a maior concentração está no chamado Setor 3. Este fica do outro lado do córrego e é o local para os eventos e shows. Atualmente está bastante descampado, com pavimentação em sua maior parte. Futuramente, pretende-se implantar caminhos com piso diferenciado, fazer o plantio de árvores e criar espaços de descanso com bancos.

As reformas do parque continuam. A cada visita é possível verificar alterações de piso, de vegetação, ambientação e até mesmo nova localização de brinquedos.

Existe um Plano Diretor para o parque, que está em fase de implantação, no qual se podem notar propostas para atender a algumas das questões de acessibilidade e conforto. 


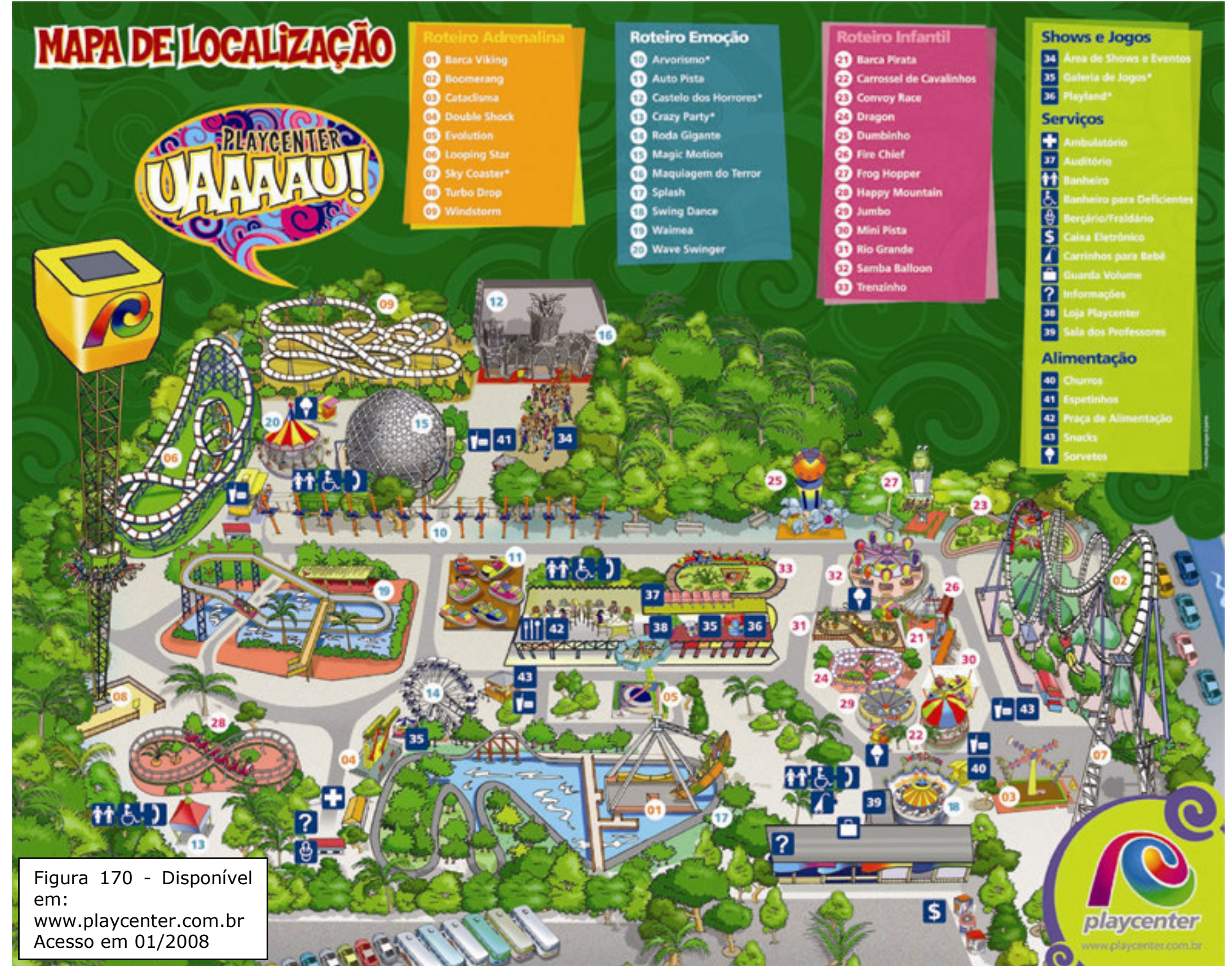




\section{Acesso ao Parque}

O parque está localizado na Vila Barra Funda, que pertence à Subprefeitura da Lapa. Foi enquadrado em ZM-3a/09, segundo o Plano Regional da Lapa. Isso quer dizer que caracteriza-se como "zona mista de densidades demográfica e construtiva alta", sendo incentivos usos industriais.

Na foto aérea, a seguir, é possível observar as dimensões dos lotes e dos quarteirões, compreendidos entre a Avenida Marquês de São Vicente e a Avenida Marginal do Rio Tietê, nos arredores do Playcenter. É uma área de várzea, extremamente pavimentada e cortada por córregos. O Parque é atravessado por um deles.

A ocupação é basicamente de grandes galpões e a área está em transformação. Isso se deve ao fato de estar próximo à área da Operação Urbana Água Branca. A grande movimentação decorrente do Fórum Trabalhista e do Fórum Criminal de São Paulo também auxilia nas transformações.

Os principais acessos viários ao Playcenter são as Avenidas Marginal do Rio Tietê e Marquês de São Vicente. Por elas circulam veículos particulares e ônibus de transporte urbano. 


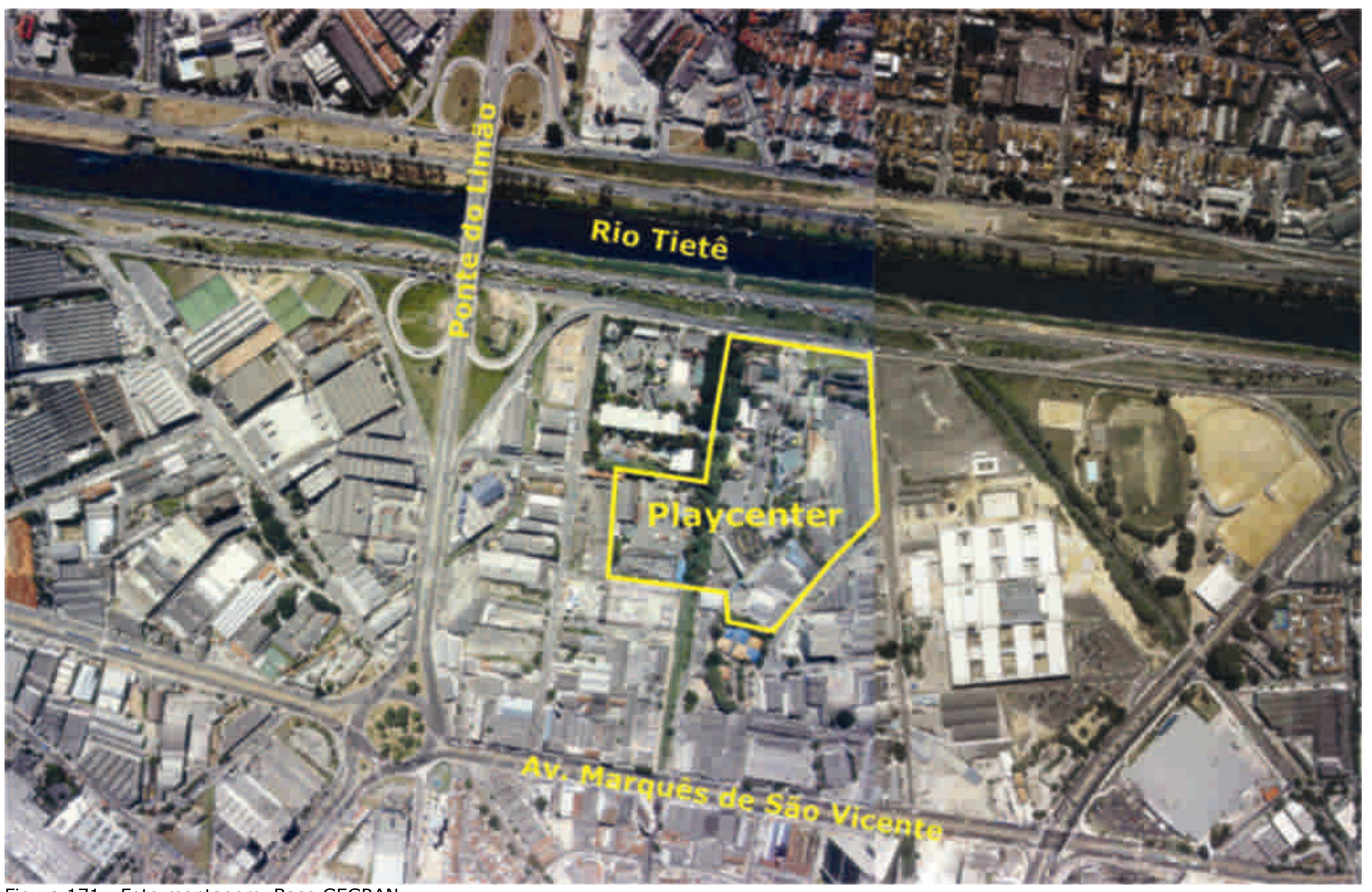

Figura 171 - Foto montagem. Base GEGRAN 


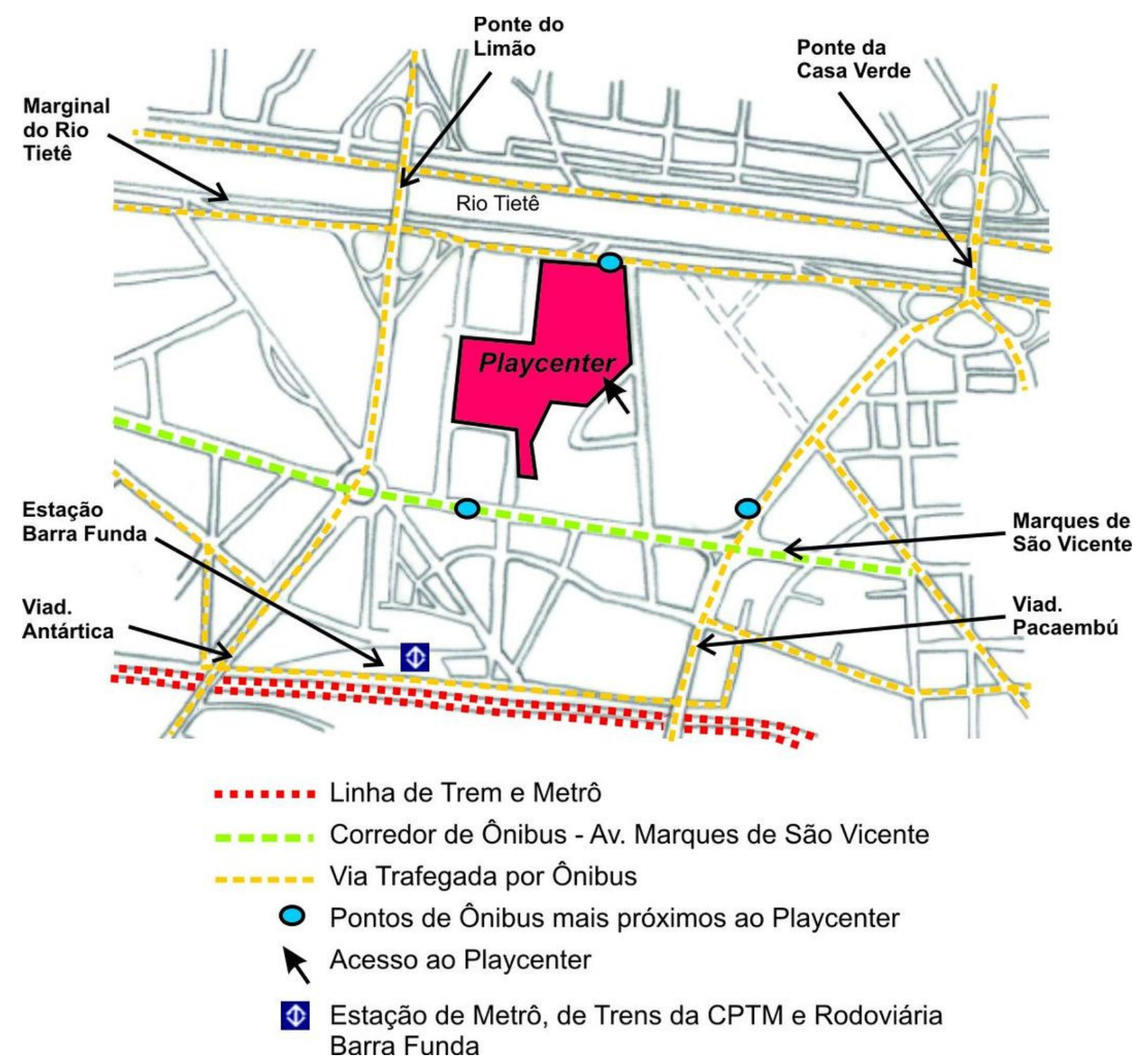

Figura 172 - Implantação do Parque Playcenter - entorno. 
A região possui farta rede de transportes, incluindo o corredor de ônibus da Av. Marquês de São Vicente e a Estação Barra Funda. Os pontos de ônibus mais próximos da entrada do parque estão num raio de aproximadamente $260 \mathrm{~m}$ e o Terminal Rodoviário Barra Funda a $550 \mathrm{~m}$, aproximadamente.

A Estação Intermodal da Barra Funda, segundo a Companhia Metropolitana de São Paulo (Metrô), interliga a linha leste-oeste do Metrô, os trens de subúrbio e de longa distância, os ônibus urbanos e o terminal interestadual de ônibus. O terminal de ônibus possui 168 linhas que "atendem 466 cidades nas regiões do Paraná, São Paulo (litoral sul e cidades ao sul e sudeste), Goiânia (cidades a sudoeste), Mato Grosso do Sul, Rondônia, além da Bolívia (Ribeira Alta)" 22.

Pela Estação Barra Funda circulam os Trens da CPTM (Companhia Paulista de Trens Metropolitanos), da Linha A, Francisco Morato-Luz e os da Linha B, Julio Prestes-Itapevi.

$22 \quad$ Disponível em

<http://www.metro.sp.gov.br/servicos/terminais/barrafunda/barra.shtml>. Acesso em abril/2007. 


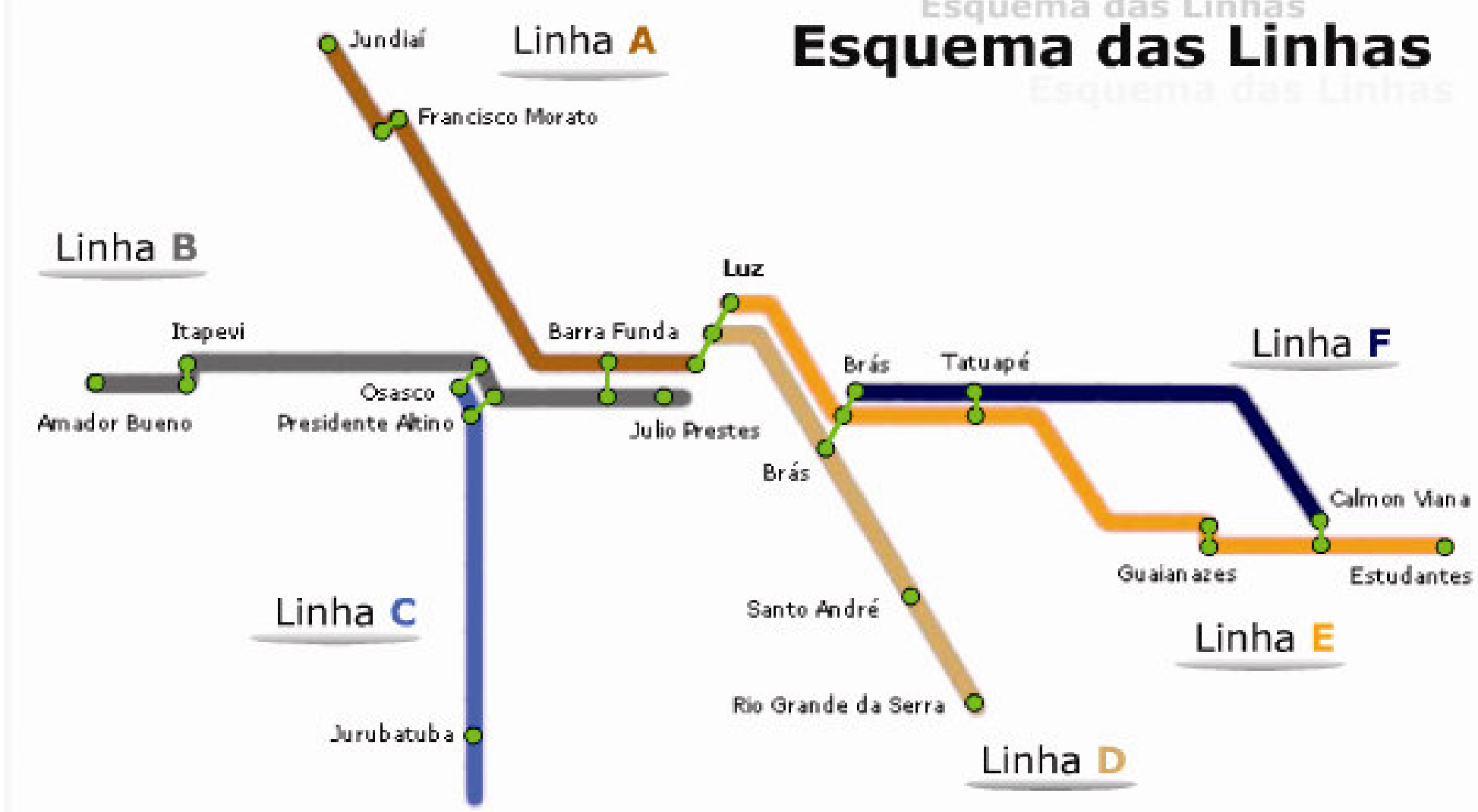

Figura 173 - Esquema de linhas de trem.

Disponível em <http://www.cptm.sp.gov.br/E REDECPTM/REDE/default.asp>. Acesso em abril/2007. 
Três ônibus do próprio Parque fazem o trajeto até o Metrô Barra Funda. Nenhum deles é adaptado para cadeirantes, nesse caso, essas pessoas são colocadas no ônibus com a ajuda do motorista e de um monitor do Parque, os quais não possuem treinamento específico para essa prática, apenas estão treinados para atender ao público em geral.

Estão em fase de implantação trabalhos de treinamento para que os funcionários possam atender, adequadamente, ao público com deficiência. O Parque oferece acompanhamento para PCDs, se o visitante assim desejar.

A Associação para Valorização e Promoção de Excepcionais (AVAPE) presta assessoria ao Parque e trabalha em conjunto com o arquiteto que realizou os estudos de acessibilidade, para o local. A partir desses estudos, foram realizadas algumas adaptações. Essa iniciativa, segundo o Parque, surgiu devido à consciência de responsabilidade social e não motivada por autuação de órgãos públicos.

No entanto, o Decreto no. 5.296 de 2004 determina que os espaços de uso coletivo, mesmo que privados, também devam atender aos parâmetros da NBR9050/2004, para tornarem-se

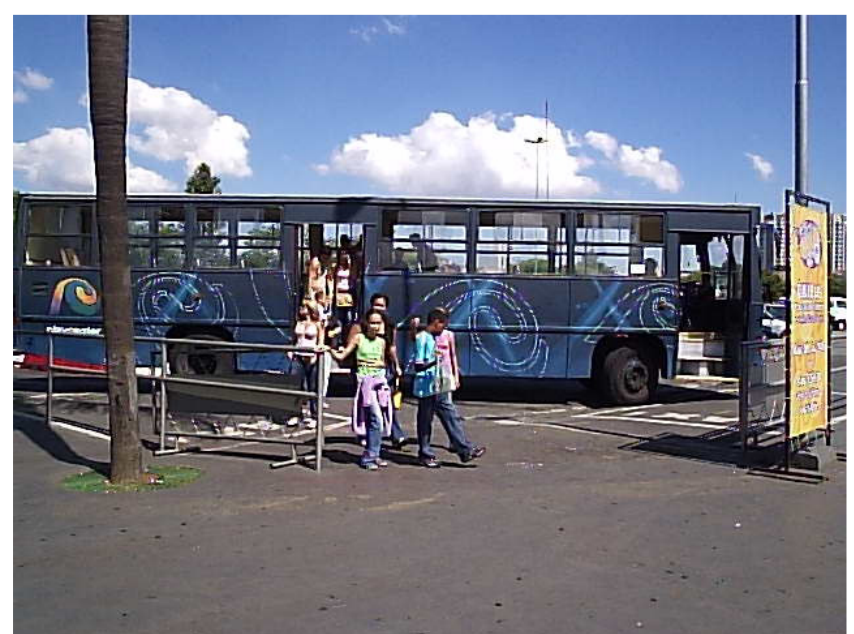

Figura 175 - Ônibus do parque trazendo visitantes.

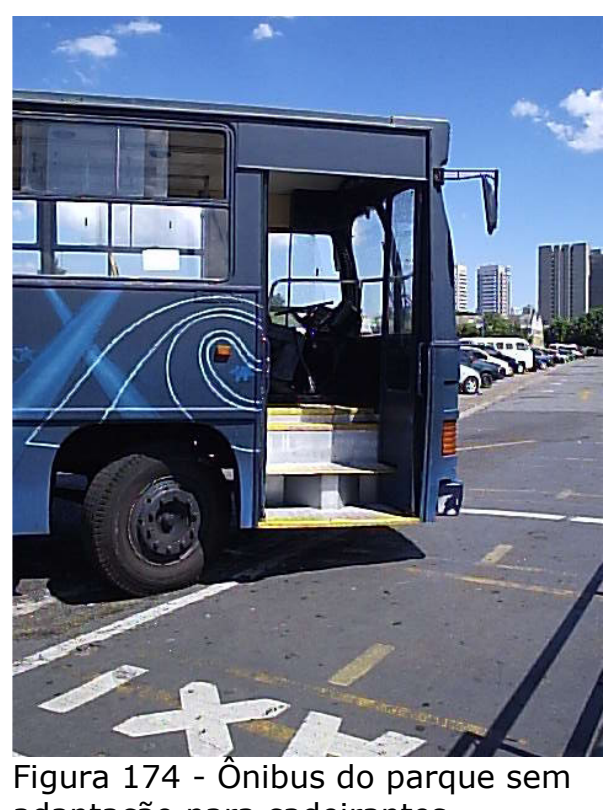
adaptação para cadeirantes. 
acessíveis e o prazo final para a adaptação, dos espaços privados, foi julho de 2007.

Outro motivo para a busca das adaptações, provavelmente, está na tentativa em garantir ganhos de imagem. De qualquer modo, mesmo essas adaptações, propostas pelo arquiteto, não foram inteiramente executadas. Ainda estão em fase de implantação e deveriam ocorrer ao longo de 2007.

Nessa reforma de adaptação, em primeiro lugar, está sendo revista questões de acesso interno, com implantação de rampas, nivelamento de pisos, sinalização visual, sonora e tátil.

A próxima etapa, será a reforma do estacionamento para o parque. Por último, serão consideradas as áreas externas, incluindo as calçadas. Essa última, provavelmente, não será executada, pois, segundo a empresa, o público freqüentador do parque pouco se utiliza das calçadas no entorno, e dessa forma não acrescentará retornos financeiros. No entanto, o ingresso ao parque deve atender a todas as faixas sociais de forma isonômica, ou seja, as pessoas que acessam o parque de ônibus, e as que utilizam as calçadas devem ter as mesmas qualidades de espaços, que aquelas que chegam de automóvel, o que na prática, ainda não acontece. 
Foi elaborado Plano Diretor para o parque, com estudo de layout para as rotas de acessos aos brinquedos, criando áreas para possível expansão ou remanejamento futuro.

O Plano Diretor prevê a implantação de piso de bloco intertravado, já existente na praça de alimentação, no setor de eventos, onde se localiza o Castelo dos Horrores. As ruas serão todas em concreto estampado e estão em fase de implantação, já bastante avançada. 


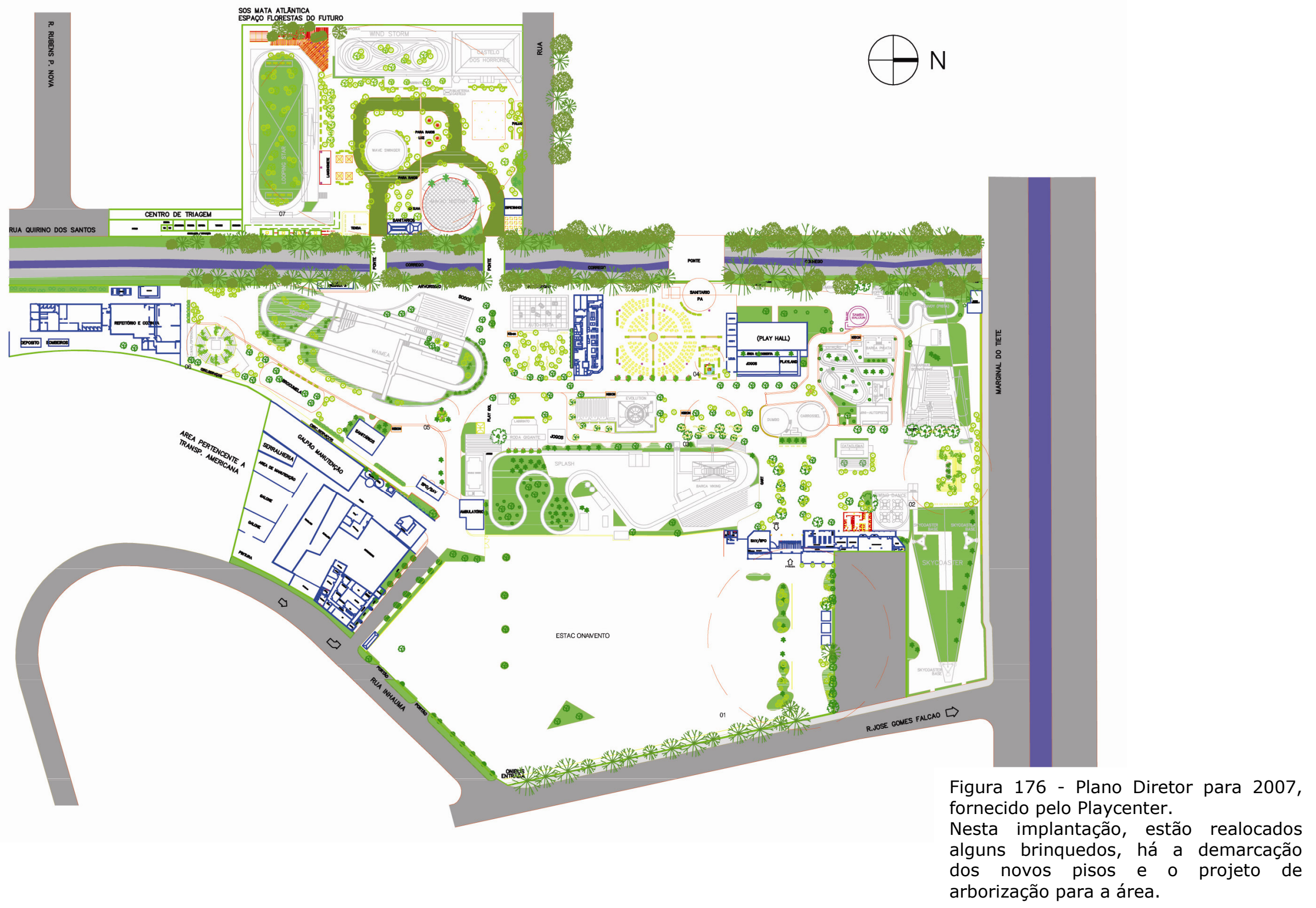


Quanto aos brinquedos, a maioria existe há anos e em seu projeto não incorporam aspectos de acessibilidade. As escadas possuem degraus grandes e irregulares. As rampas existentes são bastante íngremes.

Os brinquedos novos, também possuem os mesmo problemas dos antigos e não contemplam a acessibilidade. As escadas não têm corrimãos e os degraus são altos, especialmente para as crianças.

As atrações são acessadas por PCDs com o auxílio dos funcionários do Playcenter, os quais orientam e fazem o translado da pessoa, da cadeira de rodas para os brinquedos, quando necessário. No entanto, essa prática não é uma orientação oficial do Parque, pois esse procedimento pode causar algum dano ao usuário e o Parque seria então responsabilizado.

Há, porém, na maioria dos brinquedos, algum tipo de restrição de uso. Suas condições de segurança, resgate e probabilidade de traumas podem impedir a utilização de grande parte deles, por pessoas com determinados tipos de deficiência ou que tenham características conflitantes com o uso. Por exemplo, pessoas com hipertensão não devem utilizar o Turbo Drop.

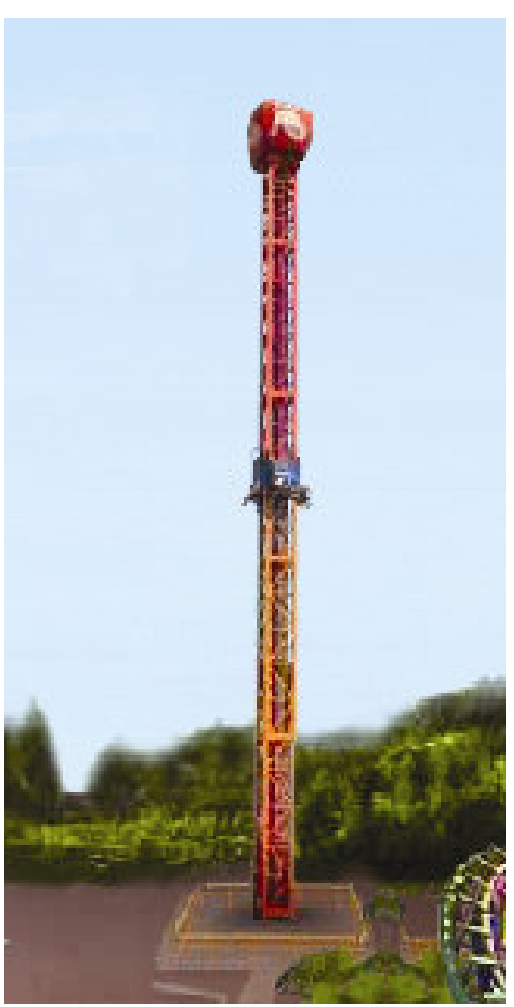

Figura 177 - Turbo Drop. Imagem base disponível em: www.playcenter.com.br 
Ao entrar no parque, a PCD é encaminhada ao Serviço de Atendimento ao Visitante - SAV - que, de acordo com seu tipo de deficiência, é informada sobre as atrações em que poderá ingressar. Se puder utilizar o brinquedo e a entrada for inacessível, o ingresso poderá ser feito com a ajuda de outras pessoas, inclusive funcionários, para o translado.

O Parque também orienta ao visitante que traga um responsável que possa fazer esse translado. Essa prática demonstra o grau de precariedade quanto ao entendimento de igualdade de oportunidades e da autonomia.

A possibilidade de ingresso nas atrações, com autonomia, deveria ser considerada pelo Parque. No caso de não haver restrições médicas de uso, os acessos e acomodações das atrações deveriam ser acessíveis. Como exemplo, se a entrada do Carrossel fosse acessível, e a cadeira de rodas fixada ao brinquedo, não haveria restrições de uso.

As impossibilidades de autonomia de acesso, de modo geral, são compensadas pela imensa atenção e boa vontade dos funcionários do Parque, que atendem com zelo e compreensão às PCDs.

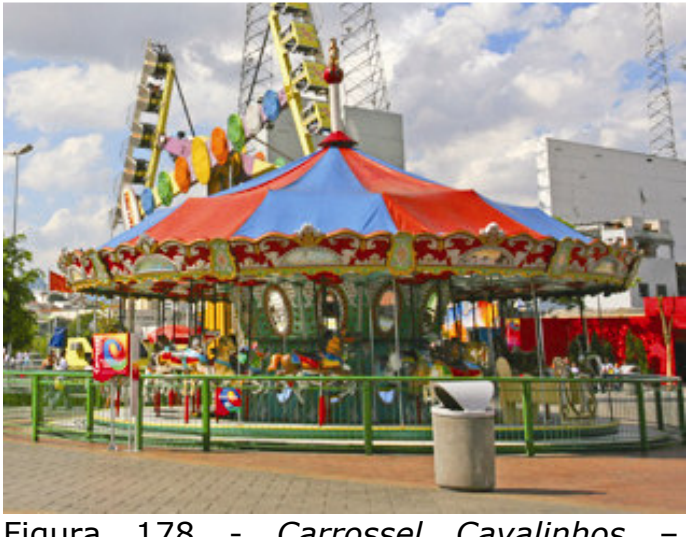

Figura 178 - Carrossel Cavalinhos disponível em:

www.playcenter.com.br 
Algumas das restrições impostas ao uso de certas atrações, referem-se às condições de resgate. O Boomerang, por exemplo, é uma montanha russa que, para resgatar um cadeirante na parte mais alta do percurso, seria necessário mecanismo específico de retirada, pois a inclinação é bastante acentuada, chegando a aproximadamente $45^{\circ}$.

$\mathrm{Na}$ entrada do parque, existem catracas de acesso e a cada duas delas um portão atende ao cadeirante, porém, a rampa com entrada mais adequada fica ao lado, e é por lá que essa entrada acontece.

Como previsto em projeto, foi instalado piso tátil de alerta em todas as rampas, como exige a Norma, e também em alguns poucos lugares, como o guarda-volumes e a entrada do Playcenter.

No caso dos funcionários, observou-se que não existem condições de acessibilidade em suas instalações, embora o Parque também tenha funcionários com deficiências. As escadas são inteiramente irregulares, guarda-corpos em alturas incorretas, proporções entre pisos e espelhos inadequadas, corredores estreitos, falta de rampas, nenhuma sinalização e layouts caóticos. Existe a

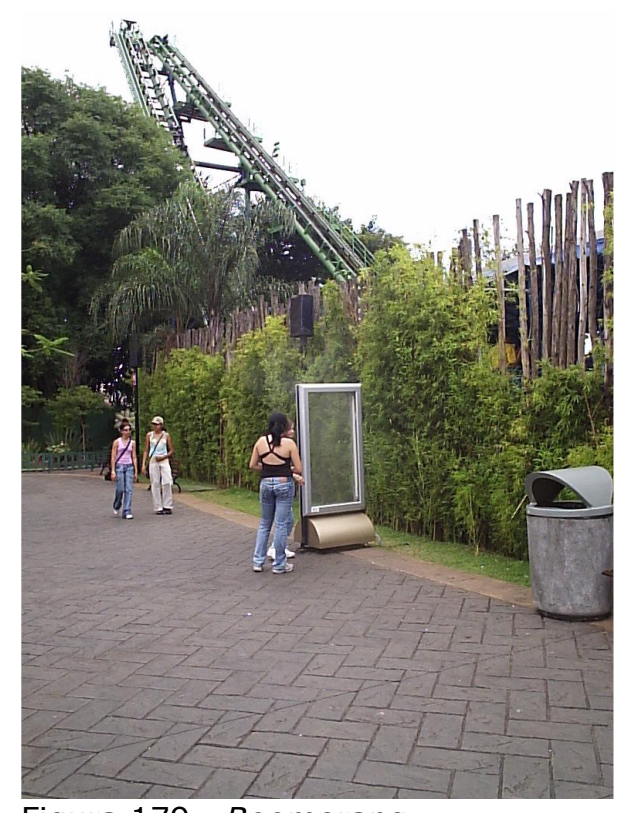

Figura 179 - Boomerang 
intenção de adaptar essas áreas ao longo de todo o processo de reforma, segundo o Parque.

Dentre os 380 funcionários, existem 14 com deficiência trabalhando nas equipes. Esses colaboradores atuam no setor de alimentos e bebidas, jogos e portaria. 


\section{Playcenter - roteiro fotográfico preliminar}

As fotos internas do Parque, foram tiradas nos dias 10 e 25 de novembro de 2006. As fotos do entorno são do dia 9 de abril de 2007. Todas efetuadas pela autora do trabalho.

A entrada do parque possui piso de concreto estampado. A topografia é plana, como em boa parte do parque. As catracas são intercaladas por portões que dão acesso à cadeirantes.

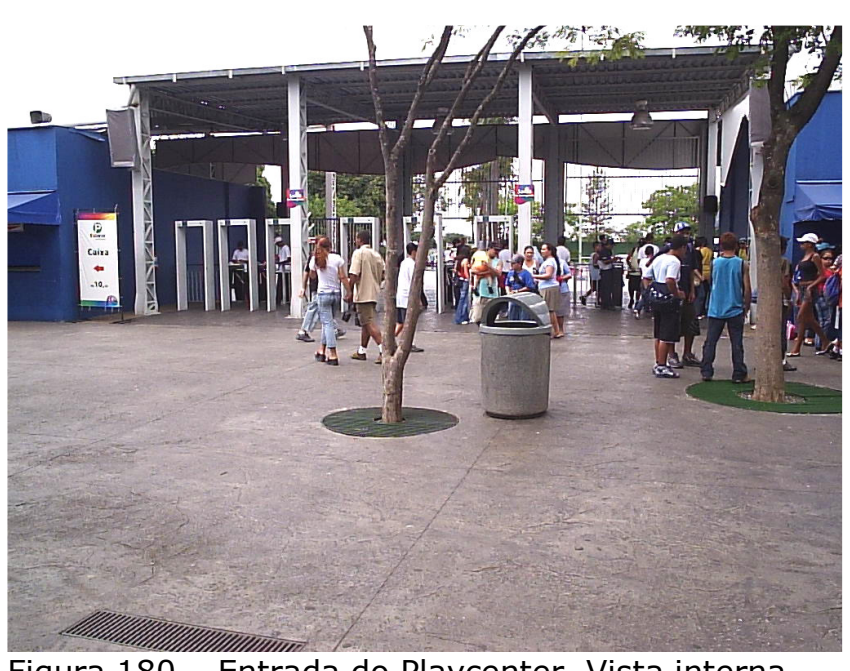

Figura 180 - Entrada do Playcenter. Vista interna.

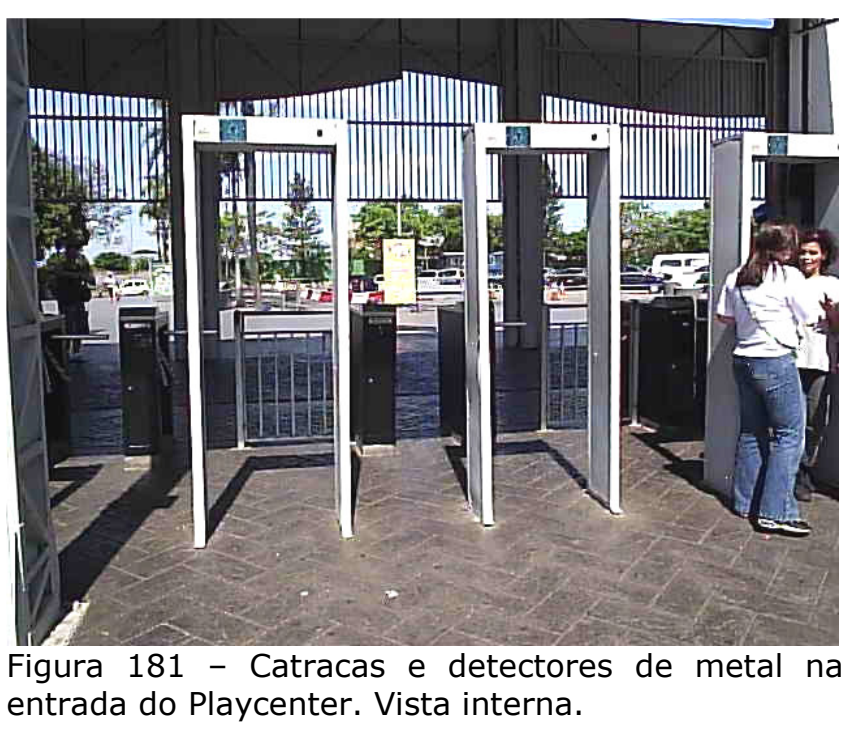


Na bilheteria, próxima a entrada, os guichês de atendimento não são altos (cerca de $1,10 \mathrm{~m}$ ), porém não oferecem condições de atender a cadeirantes, seria necessário adaptar 5\% desses, de acordo com os parâmetros da Norma Brasileira de Acessibilidade em vigor, a NBR 9050/2004.

O piso do Parque está sendo reformado aos poucos. A circulação será toda em concreto estampado e os brinquedos ficarão sobre blocos intertravados. A atual situação proporciona desníveis na transição de uma área para outra e não cria degraus, como se pode ver na foto inferior.

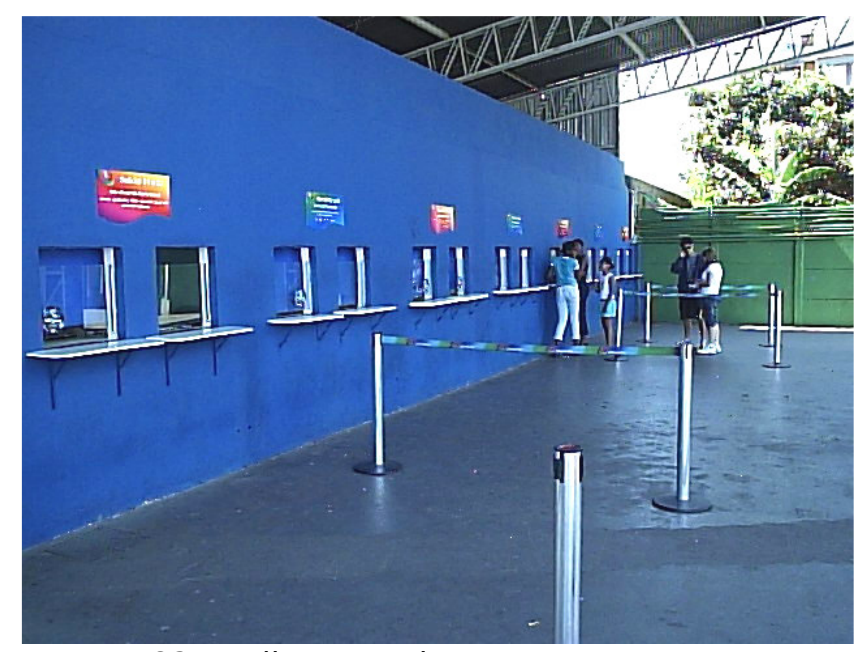

Figura 182 - Bilheterias do Parque.

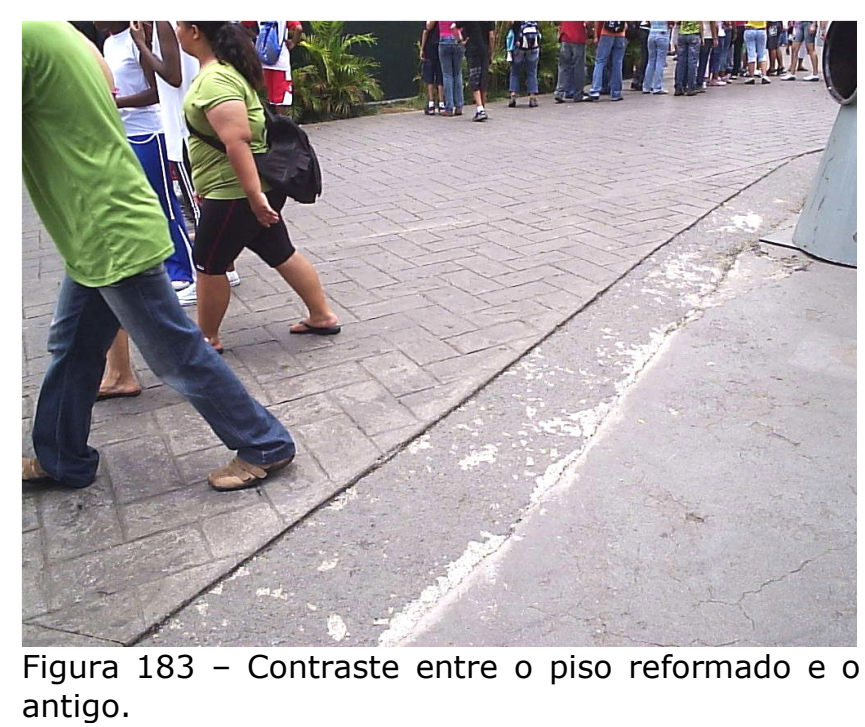


Os balcões de atendimento ao público, sejam em quiosques de alimentação, ou de jogos, não são acessíveis tanto para cadeirantes, quanto para crianças. A NBR 9050/2004 estabelece critérios para o desenho desse mobiliário, sendo a altura máxima do chão 0,90m, numa superfície mínima de 0,90m de comprimento. Para a aproximação frontal, a altura livre sob a bancada deve ser de no mínimo 0,73m, com profundidade inferior livre de, no mínimo 0,30m.

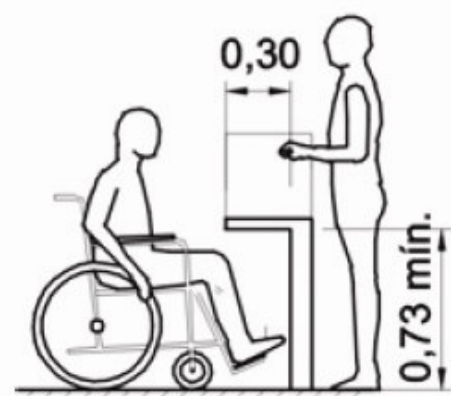

Vista lateral

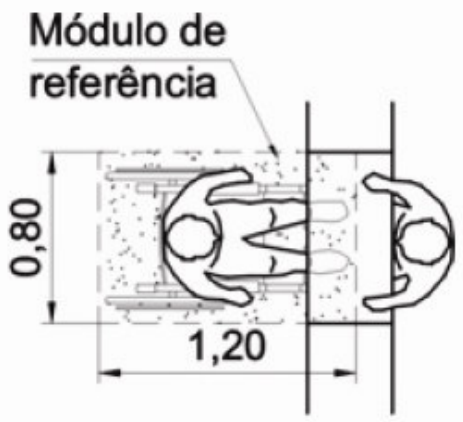

Vista superior

Figura 186 - NBR 9050/2004 - balcões
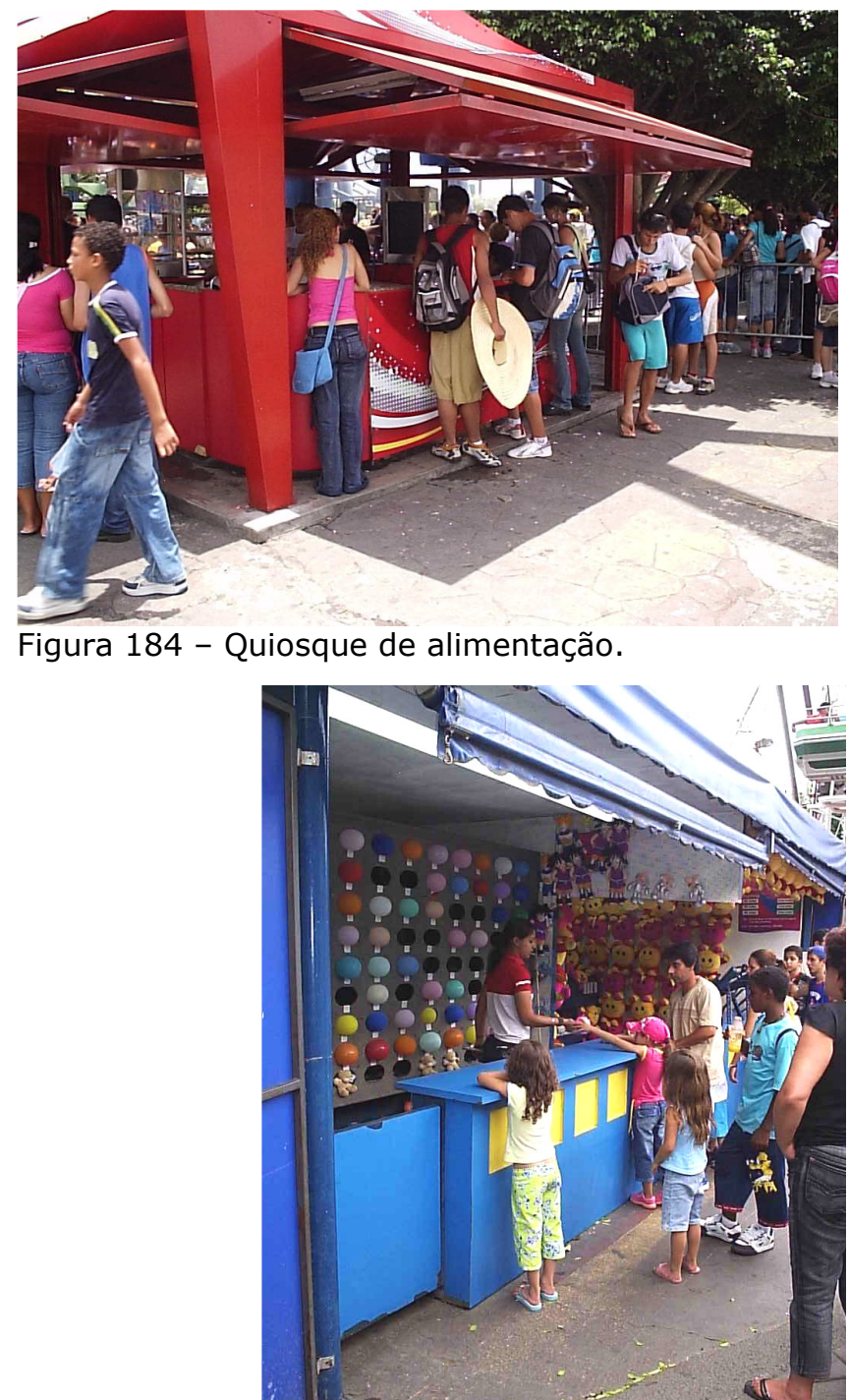

Figura 185 - Balcão da atração. Observar a relação da altura em relação às crianças. 
A praça de alimentação é plana e possui piso de blocos de concreto intertravado. O mobiliário utilizado são mesas e cadeiras fixas, que permite a utilização por cadeirantes, apenas nas extremidades. De acordo com a configuração do espaço, essa condição não é suficiente e confortável para atender a essas pessoas.

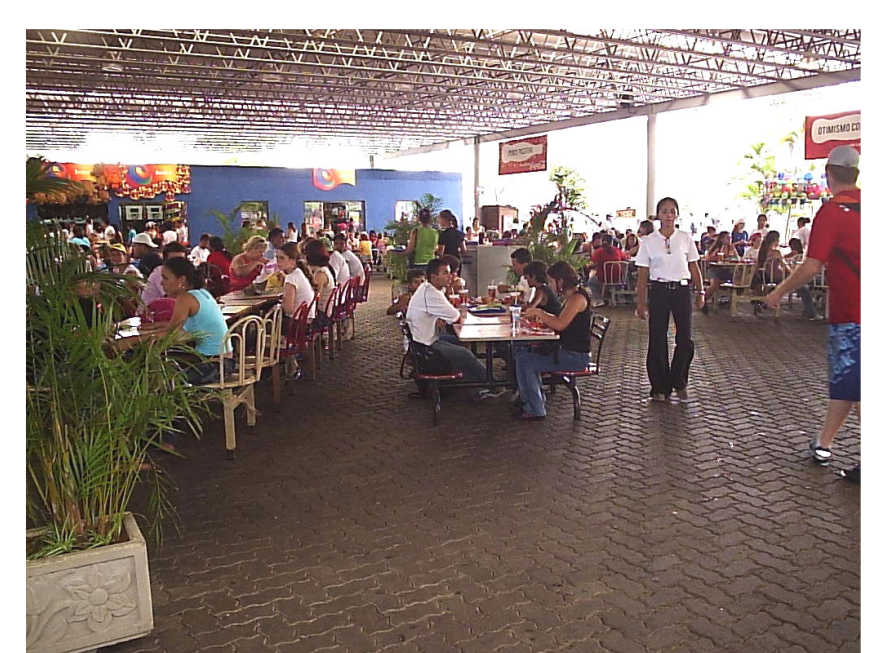

Figura 187 - Praça de alimentação do Playcenter.

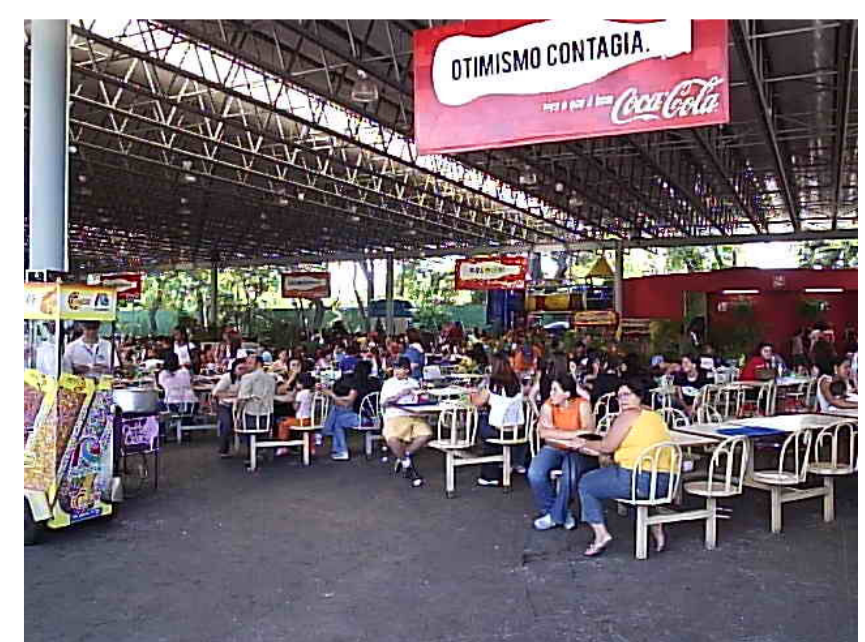

Figura 188 - Mobiliário da praça de alimentação do Playcenter. 
Entre a circulação geral do parque e a praça de alimentação existe desnível, no entanto, em alguns pontos têm rebaixamentos para acesso de cadeirantes, adaptados de forma precária.

No projeto de reforma está previsto o atendimento adequado para a implantação de rampas de acordo com os parâmetros da Norma, com largura mínima de 1,20m, inclinação máxima de 8,33\% e utilização de piso tátil de alerta nas mudanças de níveis de piso.

A faixa pintada no limite do degrau, atenta para a sua existência, evitando tropeços e auxiliando na orientação de pessoas com visão residual ${ }^{23}$.

Visão residual - pessoa com deficiência visual que não é totalmente impossibilitada de enxergar, possui alguma sensibilidade à luz, contrastes intensos de cores ou movimento. As pessoas de visão residual são a grande maioria dentre as pessoas com deficiência visual.

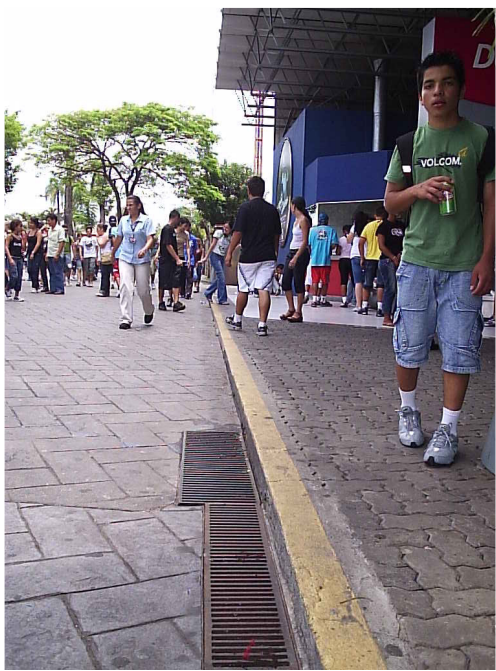

Figura 189 - Desenível entre a praça de alimentação e a circulação do Parque.

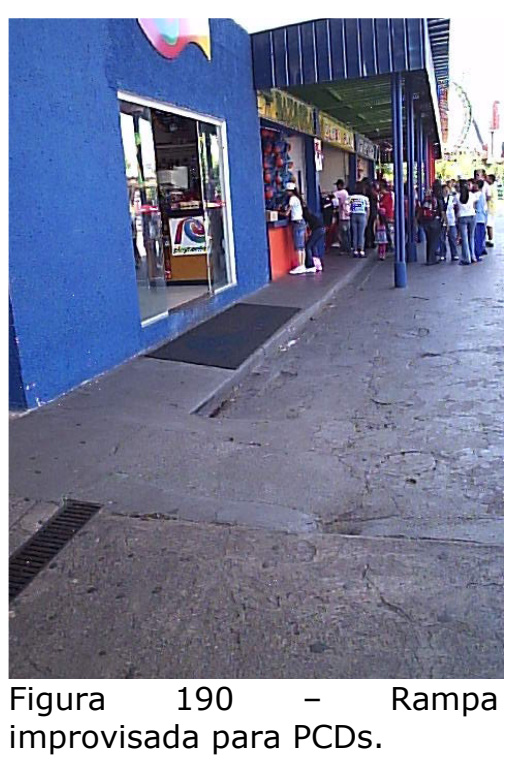


As lanchonetes da área de alimentação possuem balcões altos que dificultam o atendimento a crianças e cadeirantes. Para acolhimento às exigências da Norma, seria necessária altura máxima do chão de 0,90m, numa superfície mínima de 0,90m de comprimento, em cada um desses balcões.

Em todos os setores do parque existem banheiros e cada um deles está equipado com cabine adaptada para cadeirante. As entradas não possuem degraus e as portas têm $1 \mathrm{~m}$ de largura.

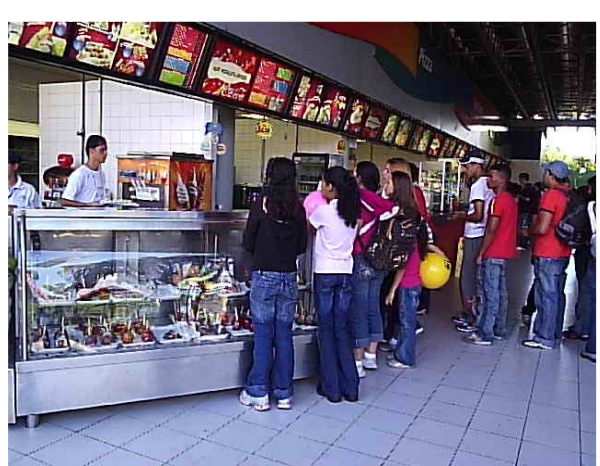

Figura 192 - Balcão de lanchonete da praça de alimentação.

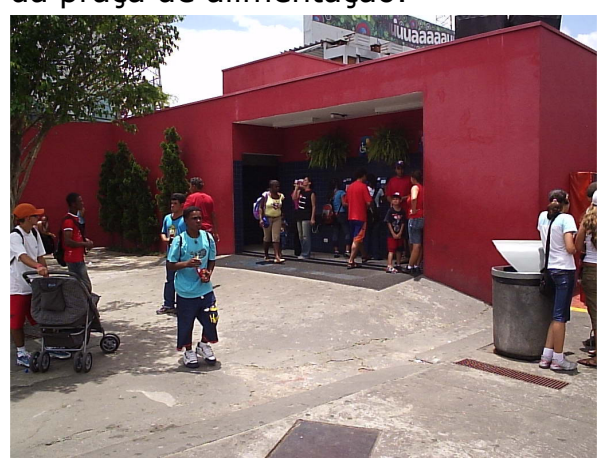

Figura 193 - entrada de sanitário.

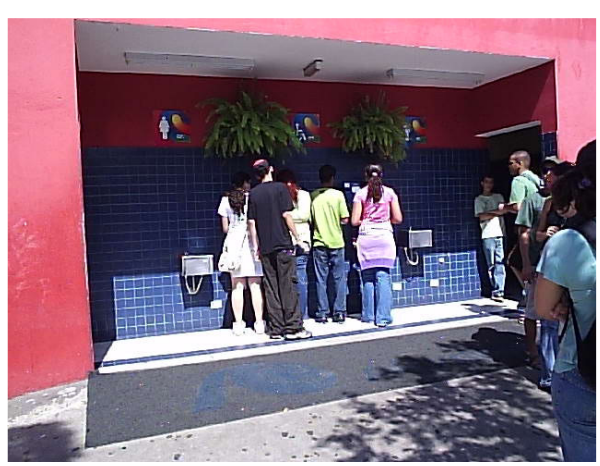

Figura 191 - entrada de sanitário. 
Os banheiros são sinalizados, identificando a possibilidade de uso por cadeirantes e indicando a existência do sanitário "familiar", onde crianças podem ser acompanhadas por seus responsáveis, independentemente do gênero, sem maiores constrangimentos.

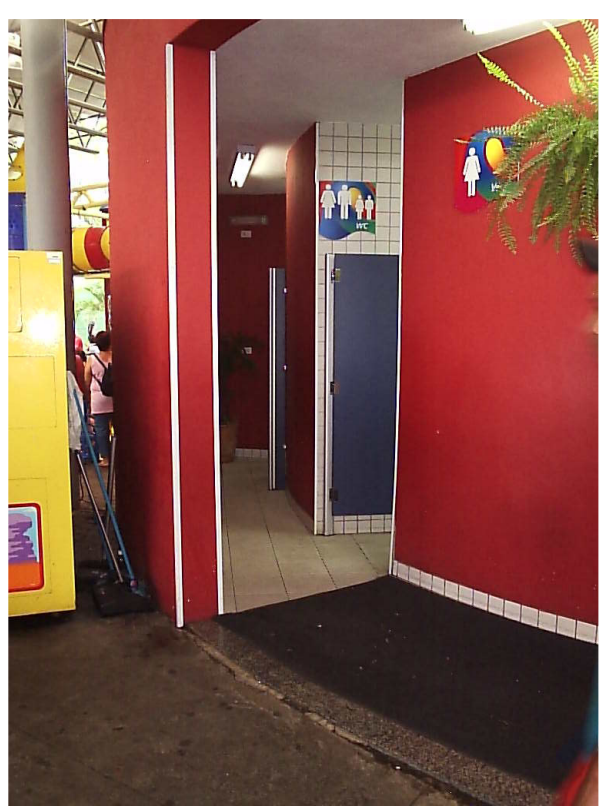

Figura 194 - entrada de sanitários. Observar entrada para sanitário familiar.

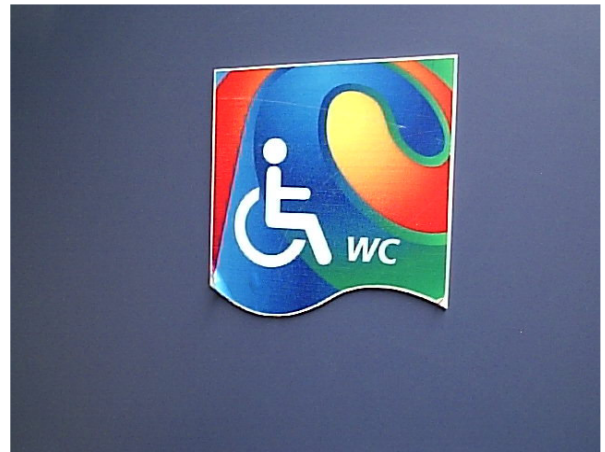

Figura 195 - sinalização de sanitário adaptado. 
Internamente, os banheiros atendem aos parâmetros da Norma quanto à colocação e localização de barras e acessórios. Porém, na foto superior, o lavatório externo à cabine, junto à bancada, atende bem a crianças e pessoas de baixa estatura, mas para que cadeirantes possam utilizá-la corretamente, o espaço sob a pia necessitaria ser livre, barras deveriam ser colocadas à frente do lavatório e o espelho rebaixado. Todos os sifões de pias para PCDs precisariam ser protegidos.

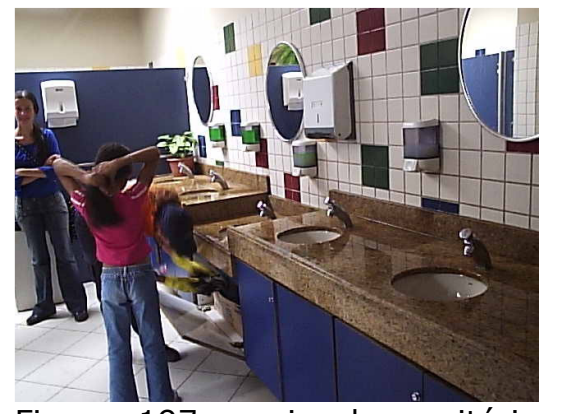

Figura 197 - pia de sanitário. Observar o trecho do tampo rebaixado.

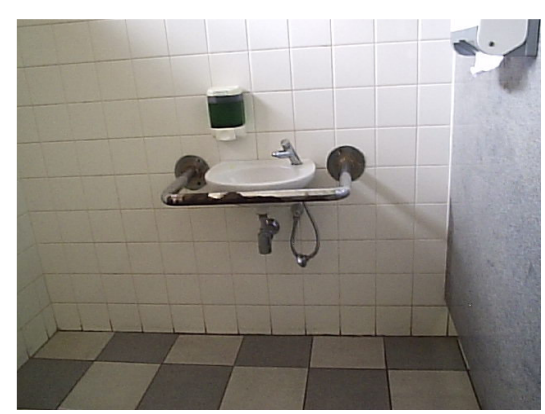

Figura 196 - pia adaptada dentro de cabine adaptada. Observar sifão desprotegido.

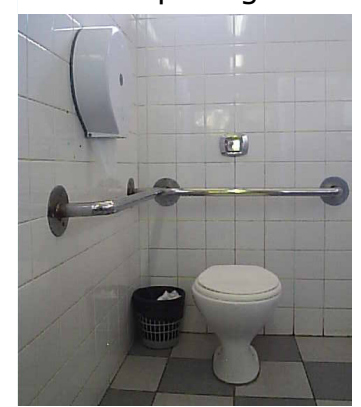

Figura 198 - sanitário adaptado. 

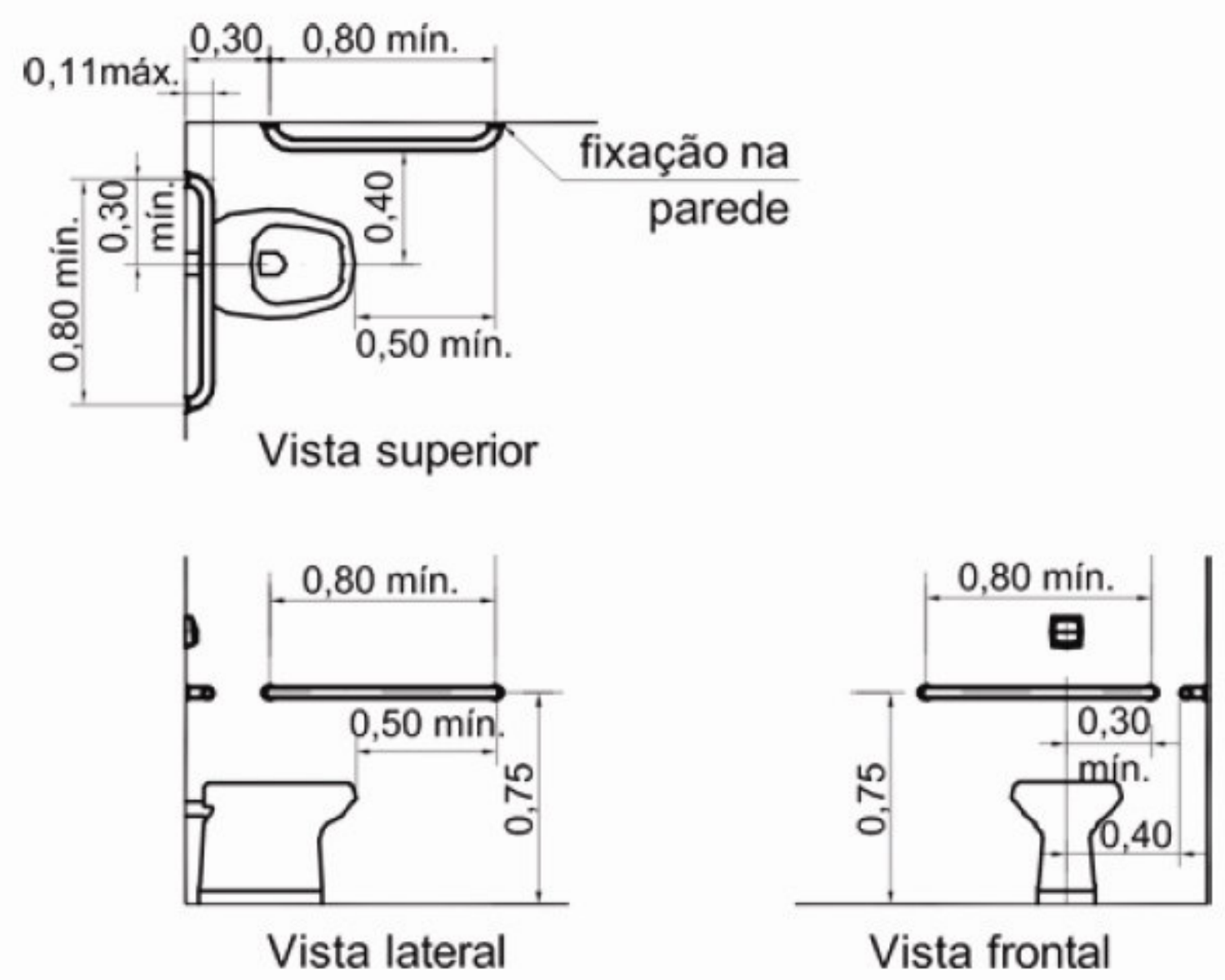

Figura 199 - NBR9050/2004 - barras de apoio para vasos sanitários 


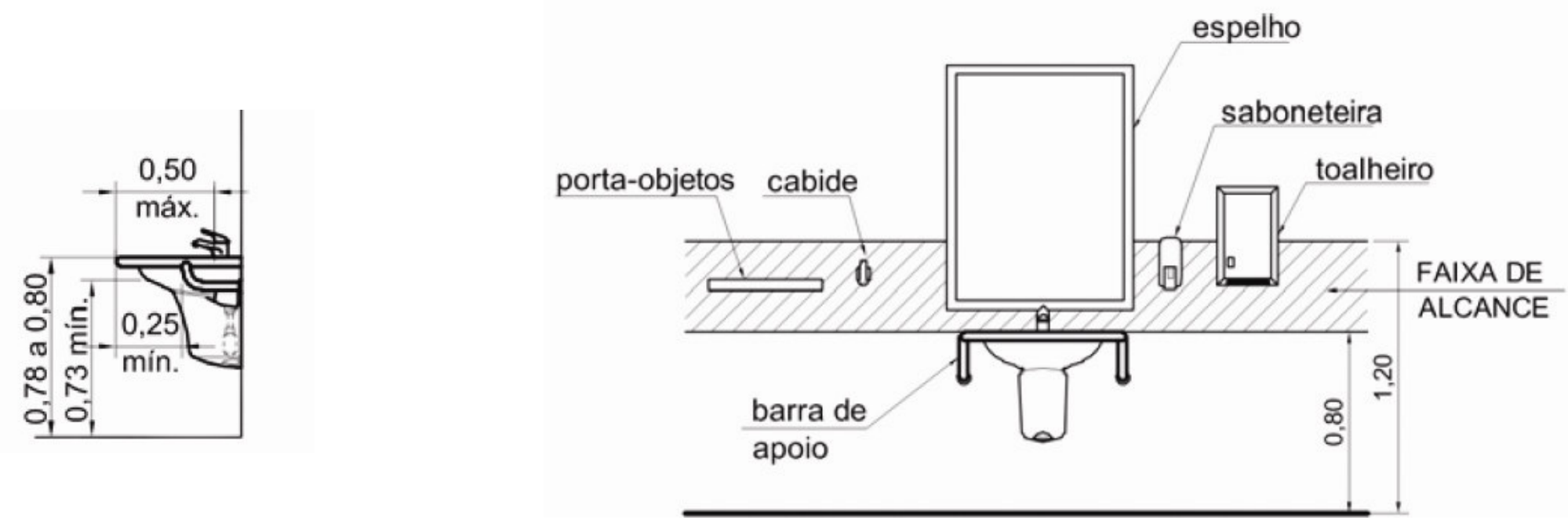

Figura 200 - NBR9050/2004 - pia em corte e em vista, alcances e alturas

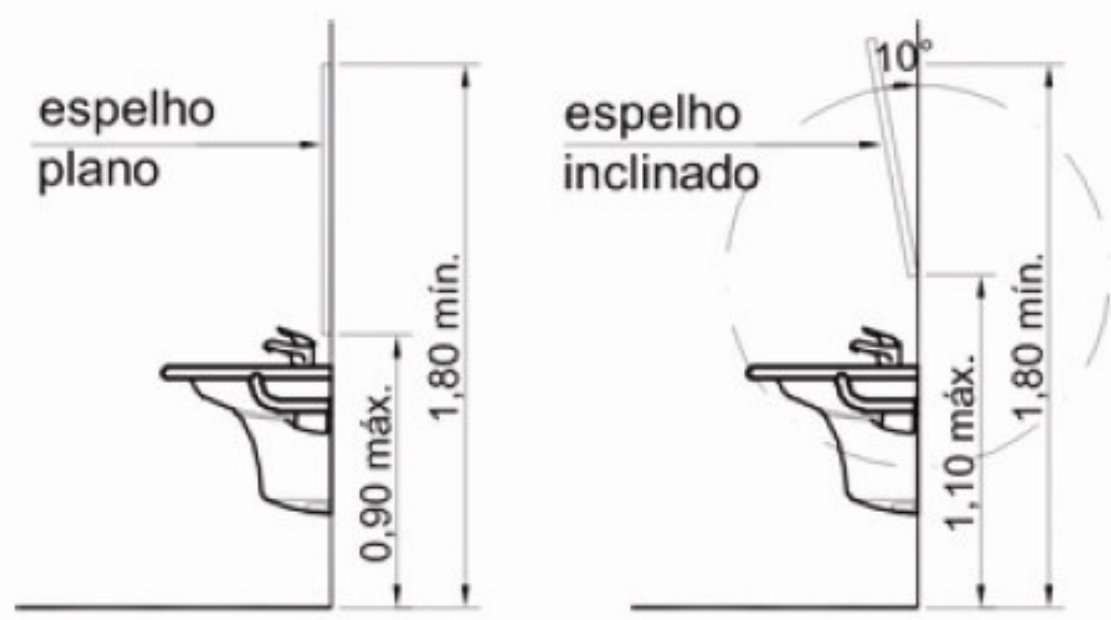

Figura 201 - NBR9050/2004 - posicionamento de espelhos para cadeirantes 
As atrações, quase que em sua totalidade, possuem plataforma de embarque e desembarque acima do nível do piso. Para vencer esses desníveis, muitos possuem apenas escadas. Essas escadas são irregulares, poucas têm corrimãos e nenhuma utiliza piso tátil de alerta, para orientação da pessoa com deficiência visual.

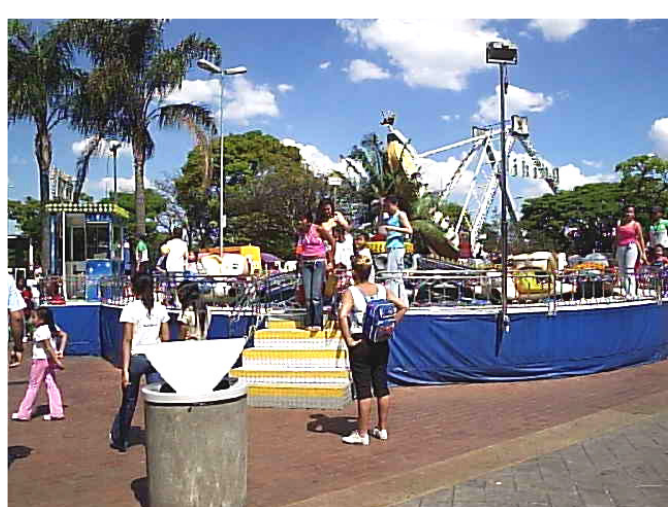

Figura 204 - escada de brinquedo, sem corrimão.

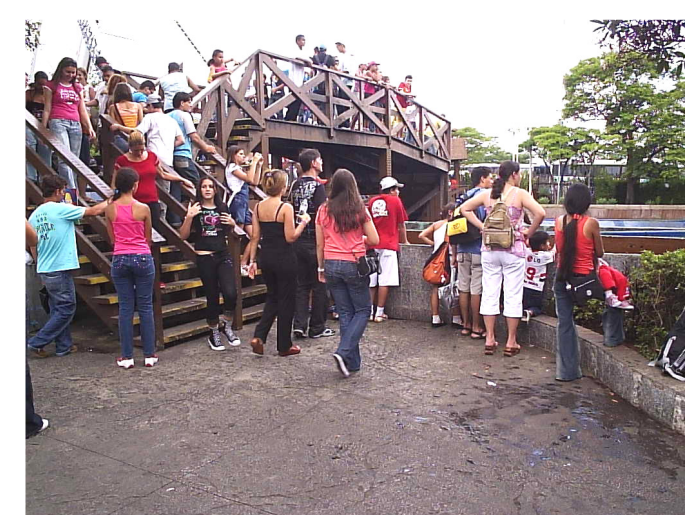

Figura 207 - escadaria de acesso ao brinquedo. Falta sinalização tátil.

Acessibilidade à Paisagem Daniela Vaz

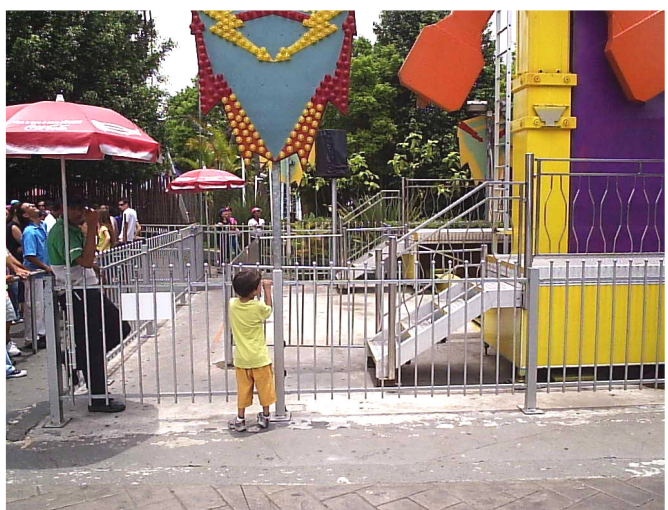

Figura 203 - escada de brinquedo com corrimãos irregulares.

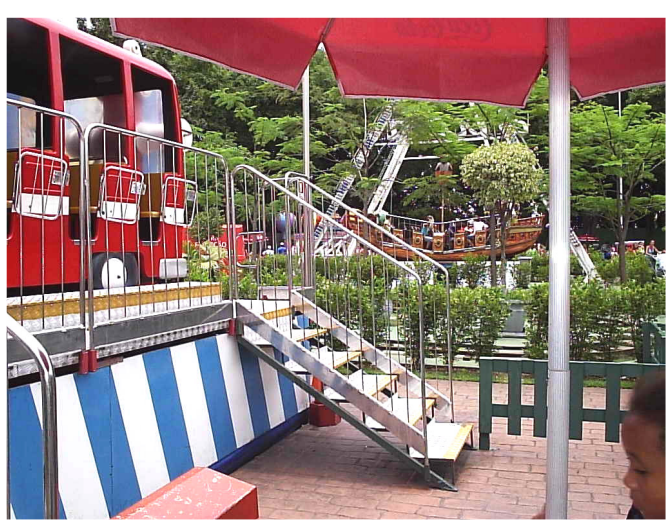

Figura 206 - escada com corrimãos fora de norma, sem sinalização tátil e sem espelhos.

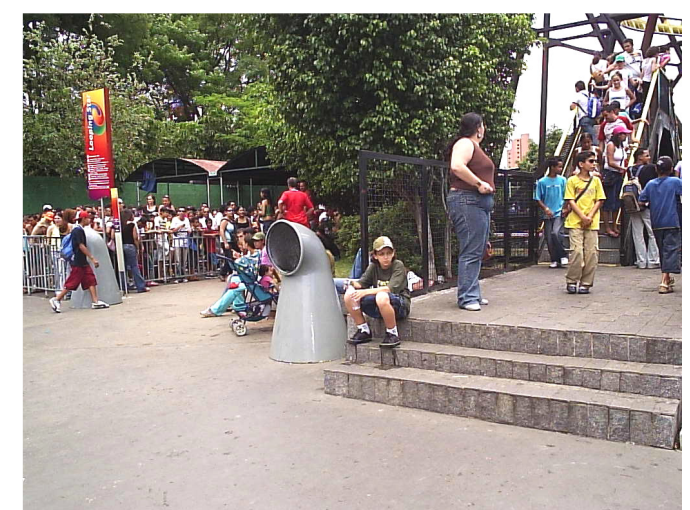

Figura 202 - escada sem sinalização tátil de alerta e corrimãos.

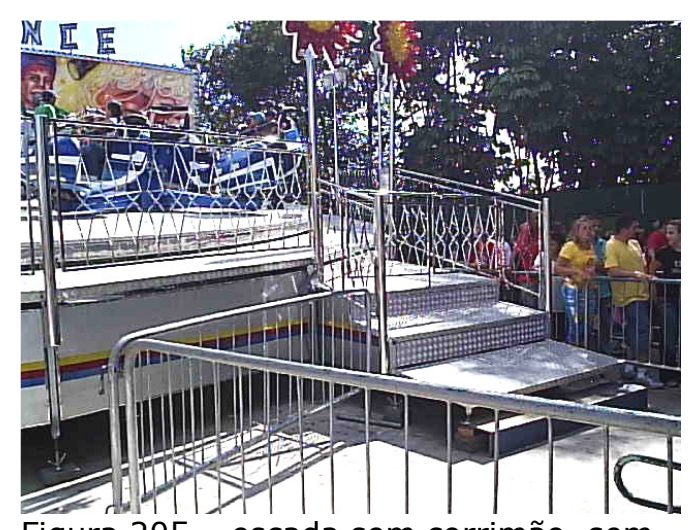

Figura 205 - escada sem corrimão, sem piso tátil e com degraus irregulares. 
Para algumas das atrações, foram criadas rampas especiais de acesso exclusivo, ou preferencial de PCDs. As inclinações não atendem ao exigido pela Norma (máximo 8,33\%), não possuem corrimãos em duas alturas $(70 \mathrm{~cm}$ e $92 \mathrm{~cm})$ e não foram utilizados pisos táteis de alerta, para indicar as mudanças de nível.

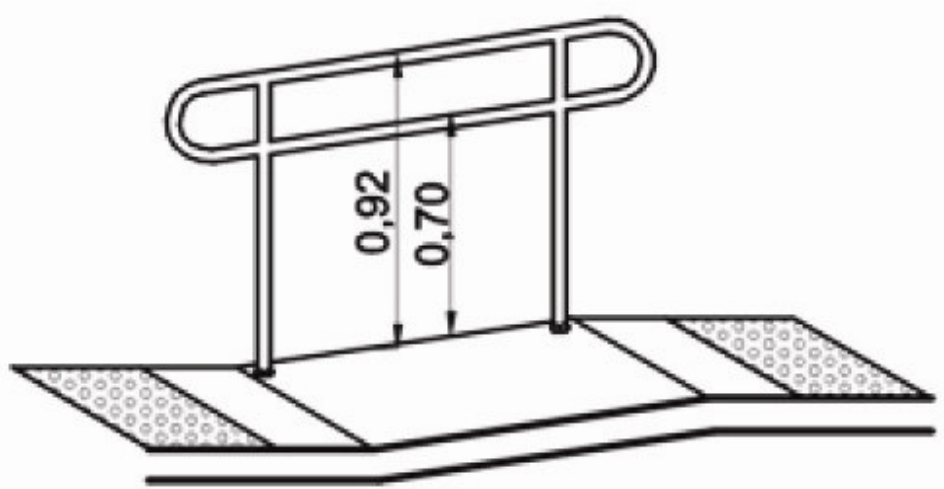

Figura 210 - NBR9050/2004- rampas e corrimãos

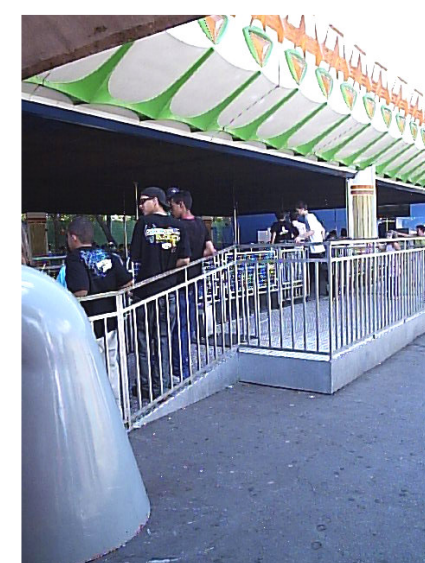

Figura 209 - rampa irregular.

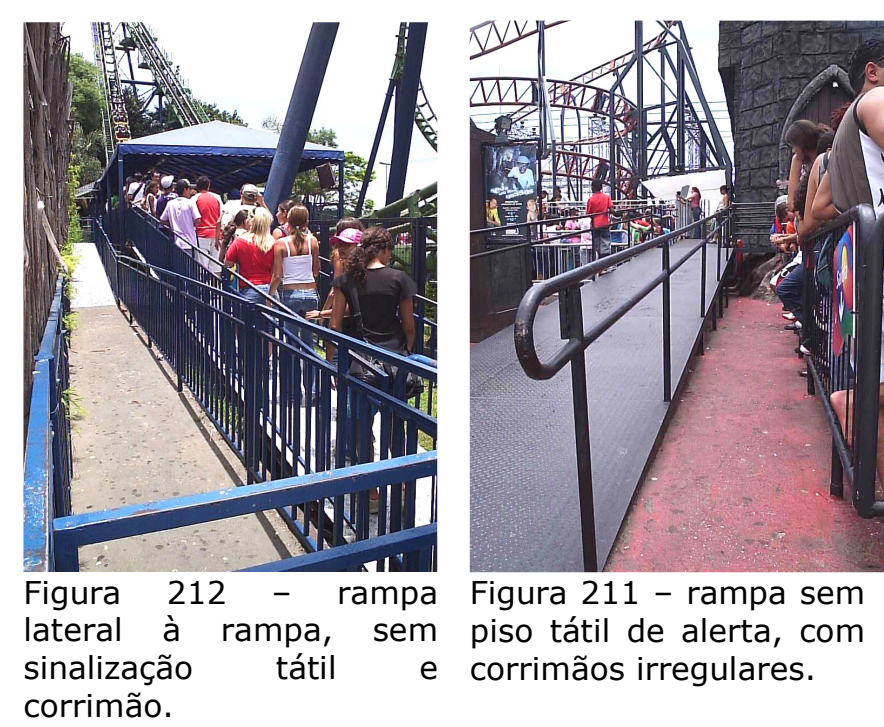


Os brinquedos voltados ao público infantil são das poucas atrações que estão em nível com o piso, facilitando entradas e saídas desses equipamentos. Atender ao público infantil requer condições de acessibilidade específicas em função das habilidades, da capacidade de equilíbrio e das dimensões antropométricas.

Os brinquedos que atendem a essa demanda são mais novos, demonstrando algum avanço no trato da acessibilidade, pelo menos para as crianças. No entanto, as dificuldades que uma criança tem são de conhecimento geral, já a problemática relativa às PCDs é menos popular, mas é tão importante quanto, por isso, essas atrações infantis não atendem inteiramente aos requisitos de acessibilidade, impedindo PCDs, especialmente cadeirantes, de terem autonomia no seu uso.

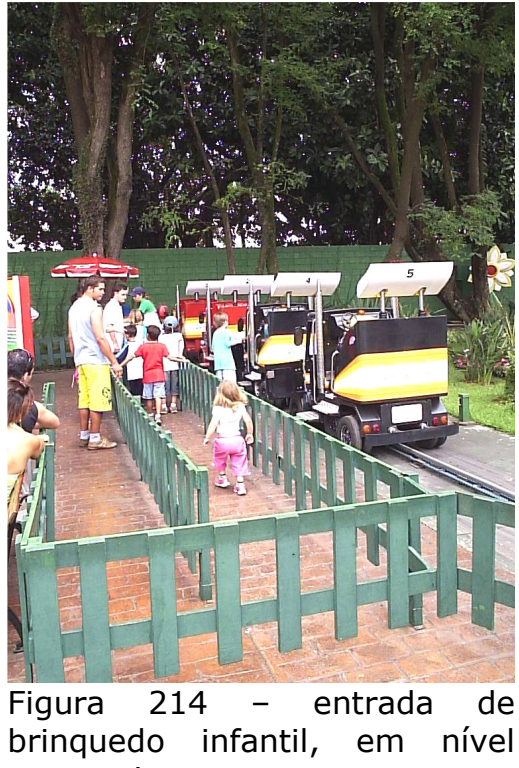

com o piso

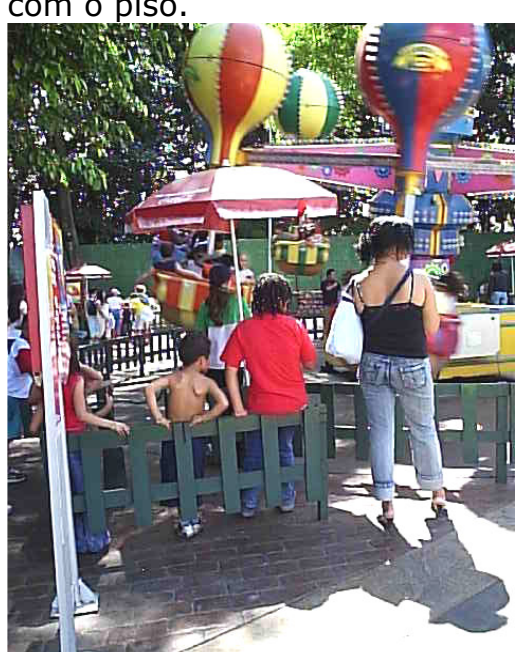

Figura 213 - entrada e espera de brinquedo, no mesmo nível do piso. 
Além dos problemas de embarque e desembarque, outra questão marcante é o fato de o próprio brinquedo não possuir assentos em condições, de acesso com autonomia, para PCDs. No caso de cadeirantes, o embarque e desembarque são feitos pelos monitores do parque.

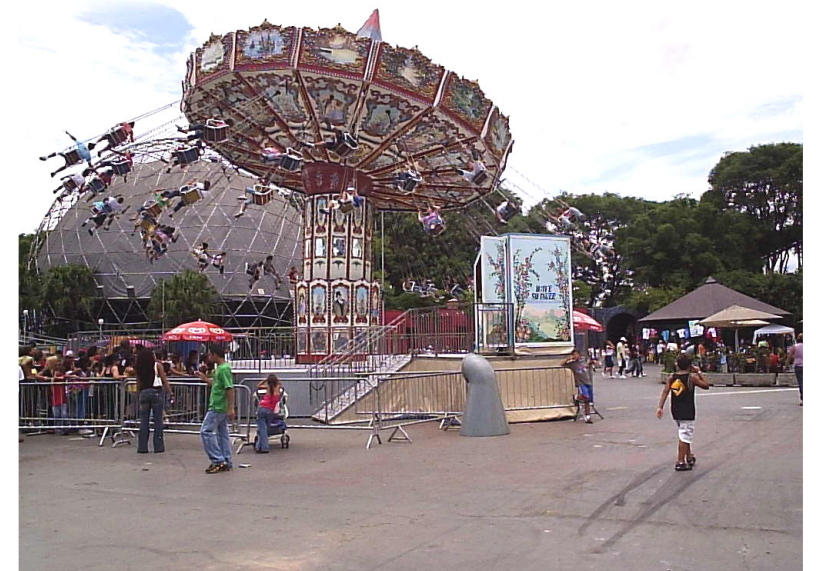

Figura 215 - Wave Swinger. Brinquedo com assentos inacessíveis.

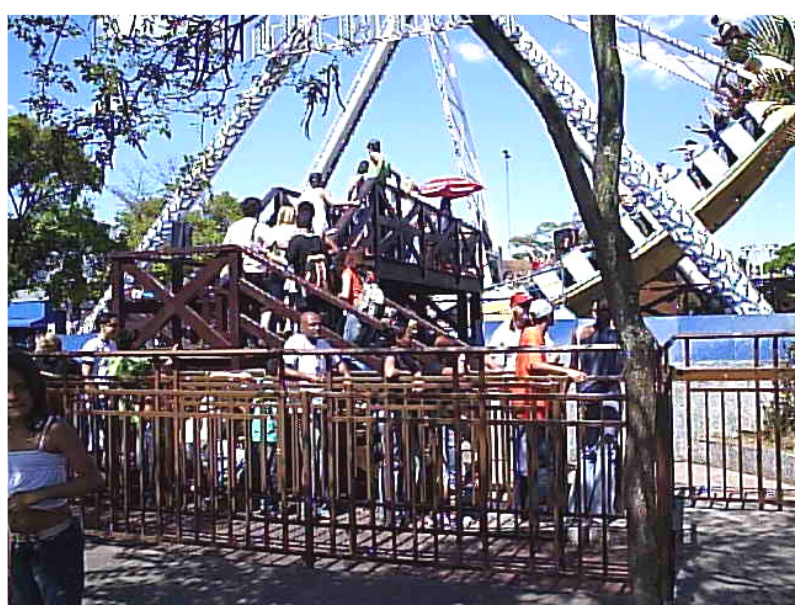

Figura 216 - Barca Viking. Brinquedo com assentos inacessíveis. 
O estacionamento do Playcenter possui 540 vagas para automóveis, sendo 8 para PCDs. Este número atende ao mínimo determinado pela Norma, que é de $1 \%$ para estacionamentos que possuam mais de 100 vagas. O desenho destas vagas não está de acordo com os parâmetros da Norma e falta a sinalização vertical indicando suas localizações.
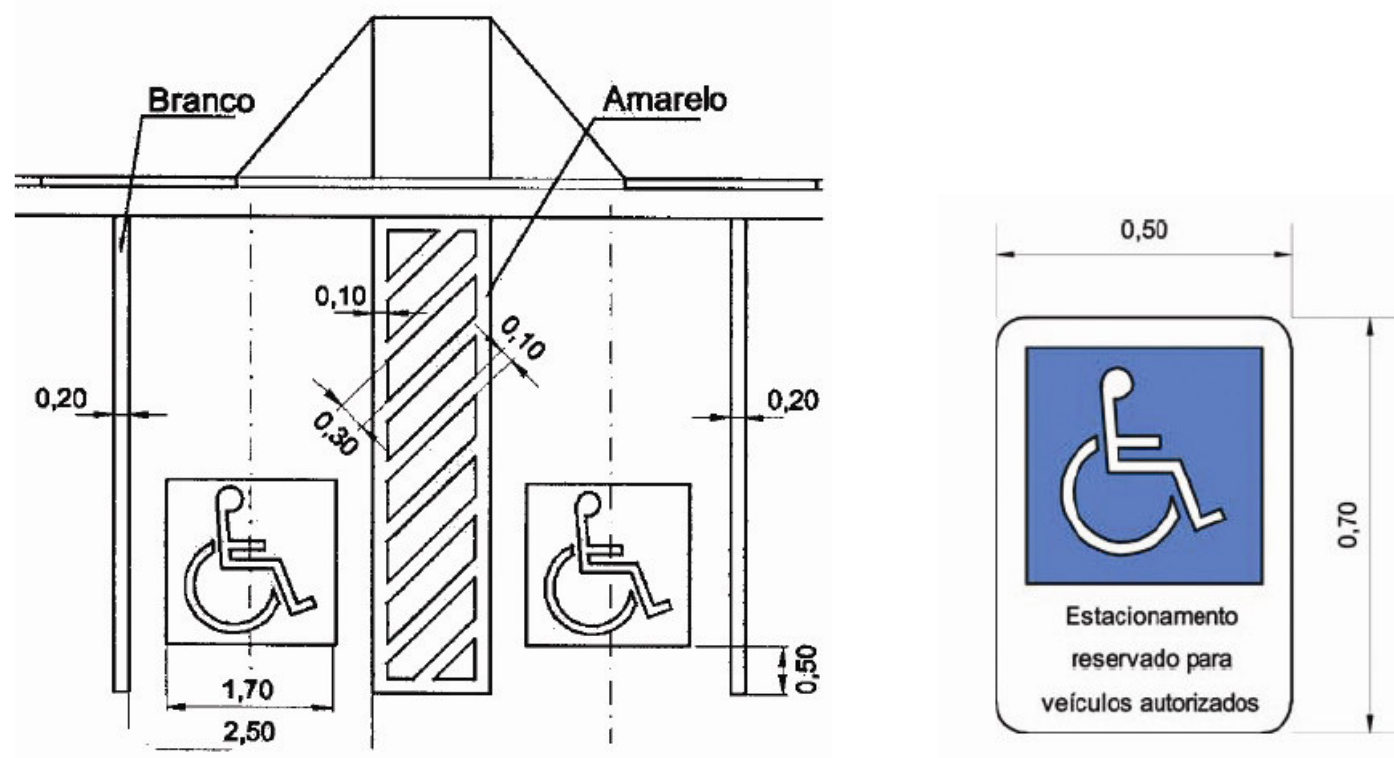

Figura 219 - NBR 9050/2004 - sinalização horizontal e vertical de vagas para PCDs. 
As calçadas lindeiras ao Parque variam entre $2 \mathrm{~m}$ e $3 \mathrm{~m}$ de largura. O piso é de cimento e a topografia plana auxilia nas questões de acessibilidade. No entanto, a manutenção desse piso é precária, especialmente junto à Marginal do Rio Tietê. Não existe qualquer tratamento da relação espacial entre o Playcenter e o passeio público, de tal forma que a calçada dá a sensação de insegurança e não permite que o pedestre tenha contato visual com o parque.

Não há uma entrada para o Playcenter diretamente da rua ou calçada. Toda pessoa que chega ao local, mesmo que a pé, deverá cruzar o estacionamento para alcançar a bilheteria e a entrada.

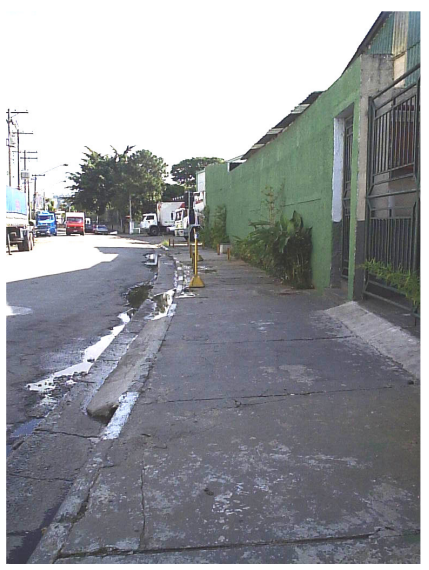

Figura 221 - calçada de entrada do Playcenter. Rua Inhaúma.

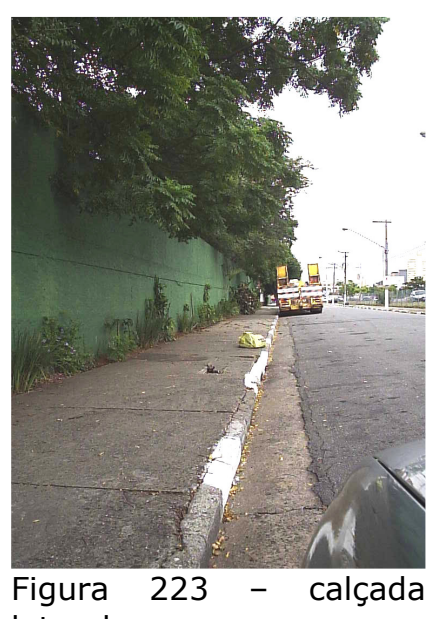

lateral

estacionamento.

Gomes Falcão.

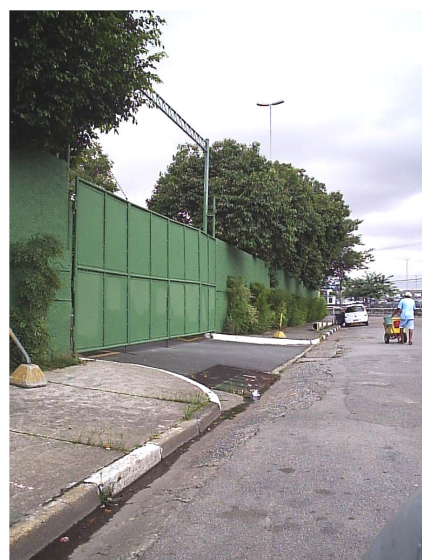

Figura 220 - portão de entrada e calçada do Parque. Rua Inhaúma.

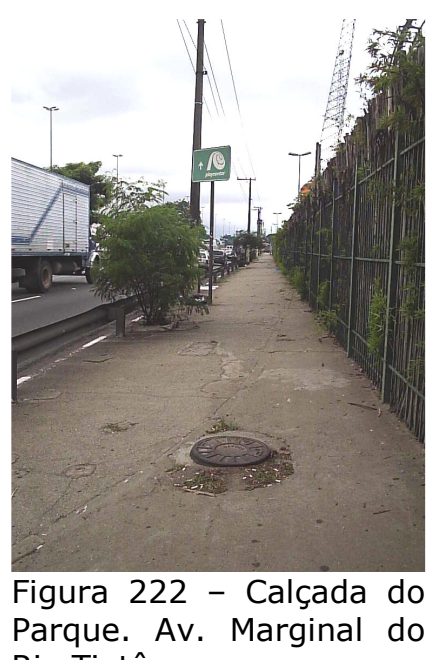
Parque. Av. Marginal do 
As travessias não possuem faixas de pedestres. Rebaixamentos de guias não foram encontrados em toda a volta do parque.

A foto superior é o encontro da Rua José Gomes Falcão com a Av. Marginal do Rio Tietê (esquina do Parque com a Marginal). Podese observar que não há faixa de pedestres, rebaixamento de guias e os elementos de orientação e segurança para automóveis impedem a travessia confortável e segura para qualquer pessoa, independentemente de suas condições.

As calçadas da Av. Marquês de São Vicente são largas (aproximadamente $3 \mathrm{~m}$ ) e planas, o fluxo de pedestres é intenso, especialmente em função do corredor de ônibus, do Fórum Criminal e do Fórum Trabalhista.

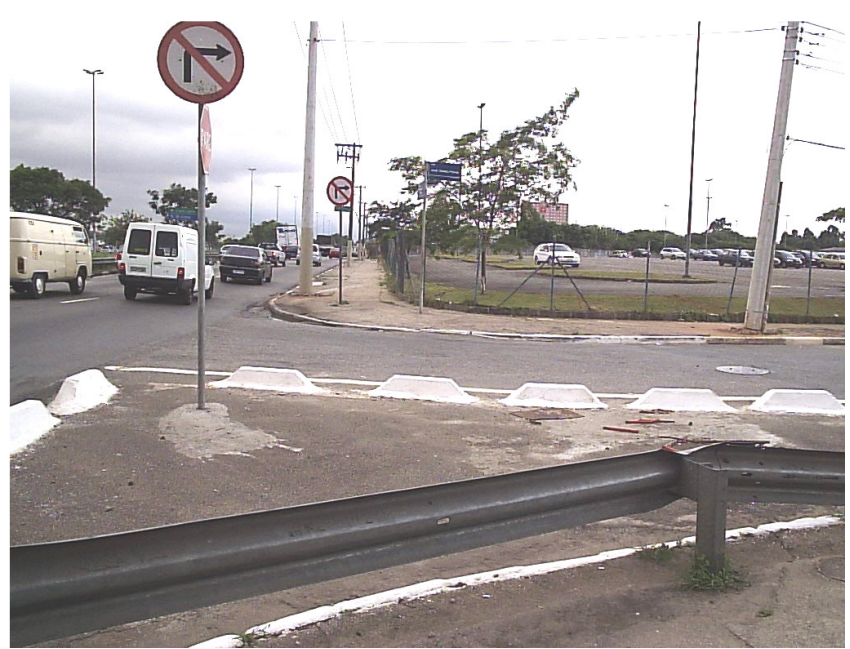

Figura 224 - esquina da Rua José Gomes Falcão com a Av. Marginal do Rio Tietê.

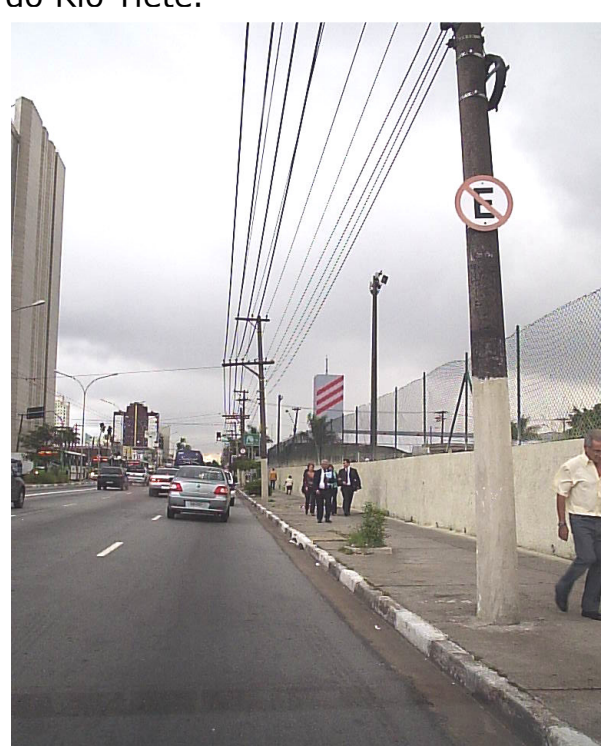

Figura 225 - calçada na Av. Marquês de São Vicente. 
Os pontos de ônibus que estão mais próximos ao Playcenter são os da Av. Marginal do Rio Tietê e do corredor da Av. Marquês de São Vicente.

No corredor de ônibus da Av. Marquês de São Vicente, os pontos ficam no canteiro central e são elevados, os desníveis são vencidos por rampas, guarnecidas com corrimãos em duas alturas, como determina a Norma.

O ponto de ônibus junto à Av. Marginal do Rio Tietê é ruim e é o mais próximo do Playcenter. Não existe sinalização tátil de alerta no piso, para orientação da pessoa com deficiência visual, e não há piso elevado para facilitar o embarque e desembarque nos ônibus.

A relação entre a pista de tráfego intenso e o espaço de espera é direta, não havendo qualquer proposta de transição entre uma situação e outra. Para o ônibus, a faixa de parada não está segregada da pista, o quê pode ocasionar acidentes e lentidão no trânsito.

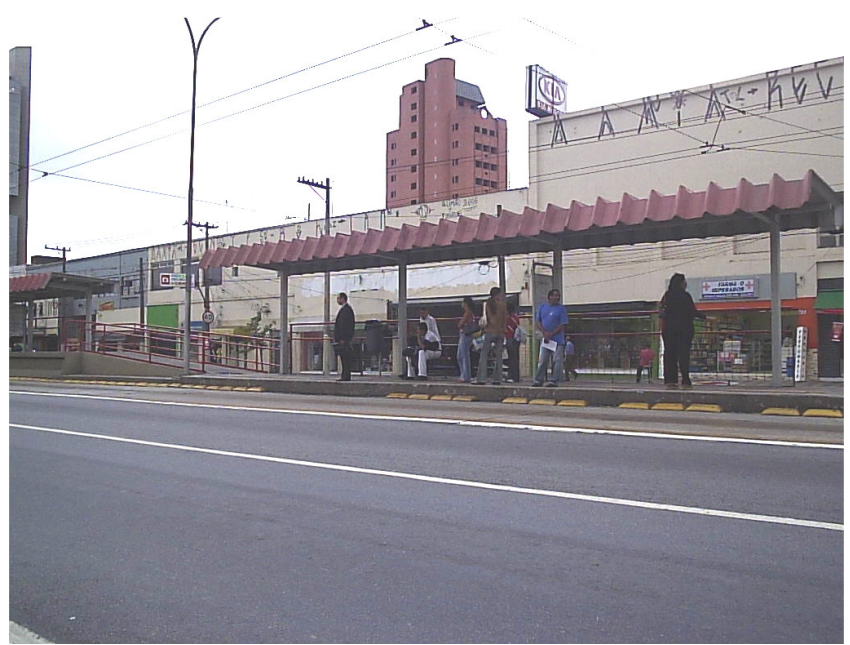

Figura 226 - ponto de ônibus na Av. Marquês de São Vicente.

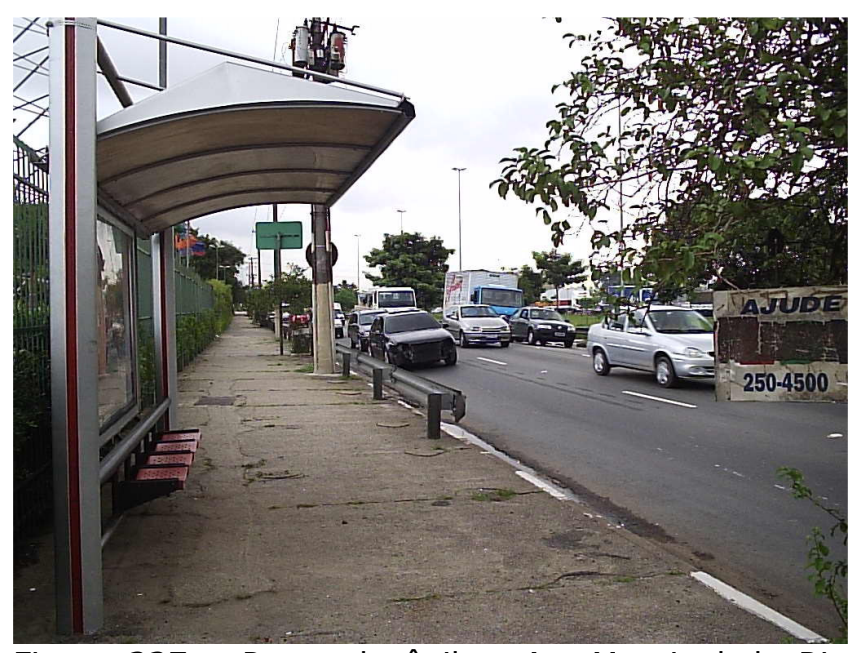

Figura 227 - Ponto de ônibus Av. Marginal do Rio Tietê. 


\section{Roteiro fotográfico - visita acompanhada por cadeirante}

Após o primeiro walkthrough ${ }^{24}$, apresentado no roteiro fotográfico preliminar, foi realizado outro roteiro, dessa vez, com cadeirante em 21 de setembro de 2007, que resultou no relatório a seguir.

O estacionamento continua com o número correto de vagas para PCDs, porém a pintura não corresponde ao exigido pela NBR9050/2004, o que dificulta a delimitação do espaço de manobra do cadeirante, necessário para o translado entre o automóvel e a cadeira de rodas.

Do estacionamento para a entrada do parque o piso possui irregularidades, como se pode ver na foto inferior.

24 Visita técnica exploratória.

Figura 229 - fala de

manutenção no piso. Acesso

do estacionamento para o

parque. 


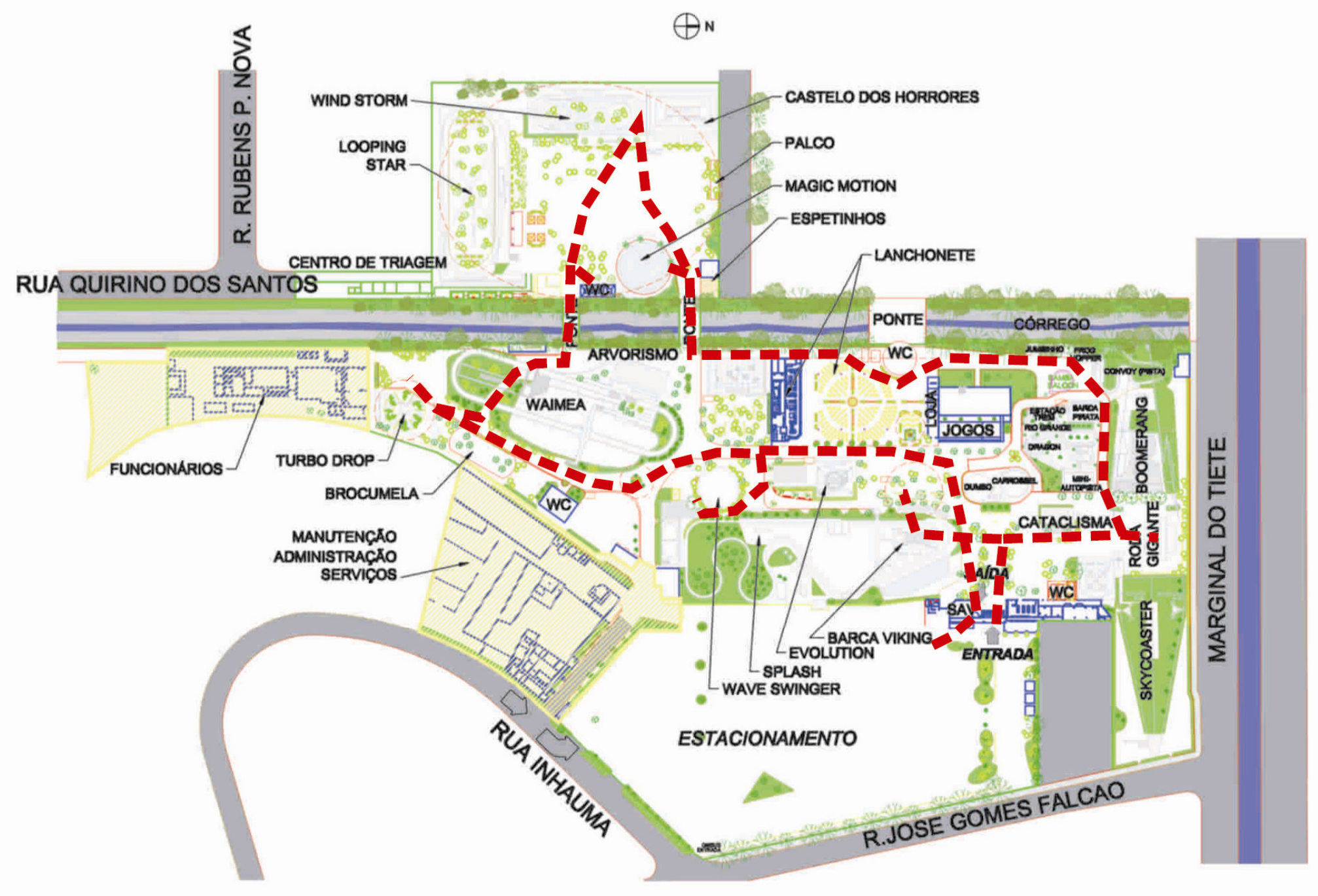

- - Roteiro percorrido

Figura 230 - roteiro percorrido com cadeirante. Mapa base - Plano Diretor Playcenter - 2007. 
O balcão de informações recebe e "avalia" as condições de todas as PCDs. Para essa "avaliação", os funcionários utilizam uma tabela com as restrições de uso de cada atração e, a partir dessa análise, selecionam os brinquedos em que esses visitantes poderão ou não participar. O balcão é alto (aproximadamente $1,10 \mathrm{~m}$ ) e não permite a aproximação do cadeirante para ser atendido, confortavelmente, pelos funcionários do Parque e assinar a ficha que contém os brinquedos selecionados.

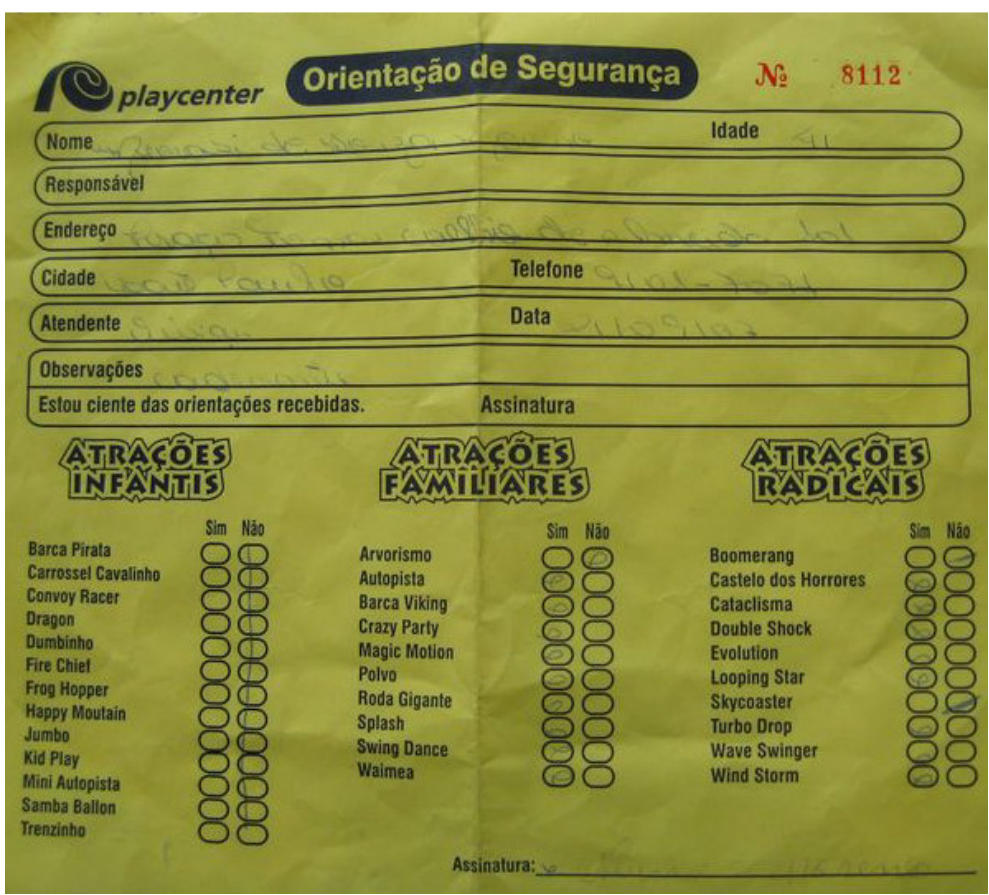

Figura 231 - Ficha de permissão para utilização de brinquedos por PCDs

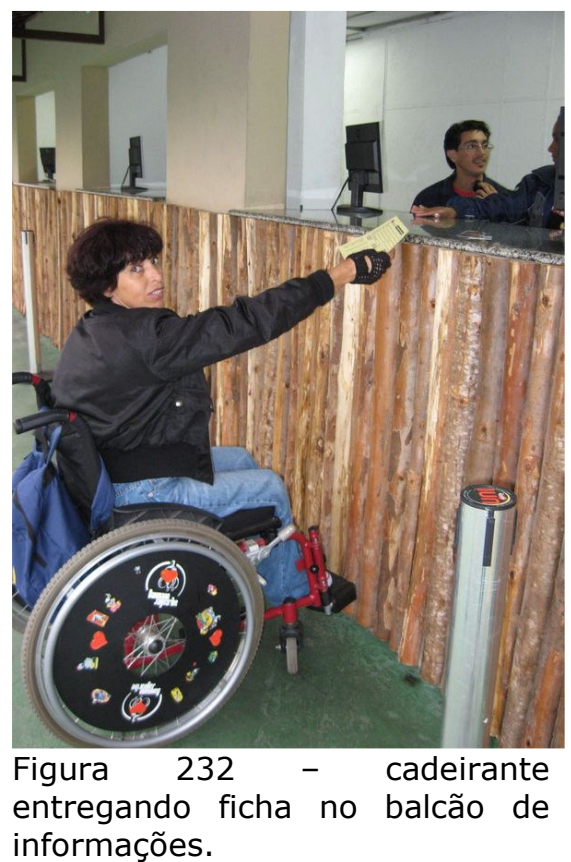

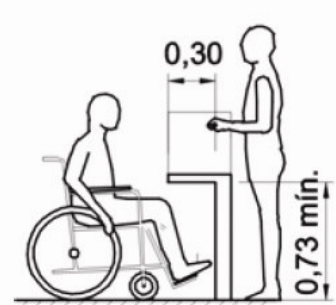

Vista lateral

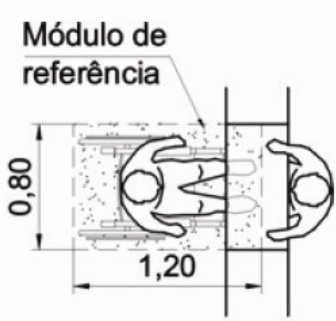

Vista superior
Figura 233 - NBR 9050/2004 - balcões 
A rampa de entrada possui corrimãos instalados em duas alturas e o piso tem faixa de destaque, que indica o caminho a ser percorrido, facilitando a orientação de pessoas com deficiência visual. Esses corrimãos não podem ser utilizados, integralmente, como seria necessário, porque não se podem deslizar as mãos, sobre eles, sem interrupções.

Para os cadeirantes, a entrada é feita na lateral das catracas existentes. Esta solução permite o acesso correto, de acordo com a Norma e faz com que esse acesso aconteça junto das demais pessoas.

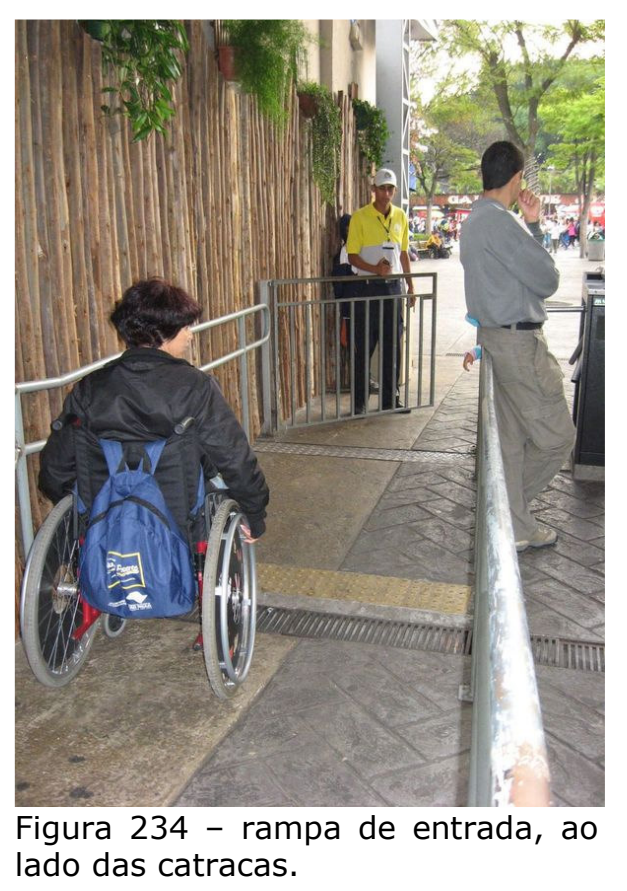


As grelhas ao longo do parque estão sendo trocadas por malha quadriculada, que são mais seguras para cadeirantes, pois evitam o risco de enganchar as rodas. No entanto, ainda existem grelhas a serem trocadas, como pode ser visto nas imagens a abaixo.

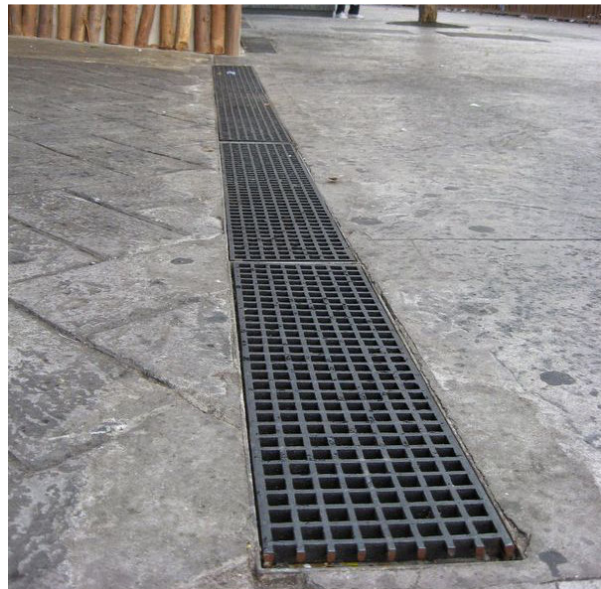

Figura 238 - grelha quadriculada.

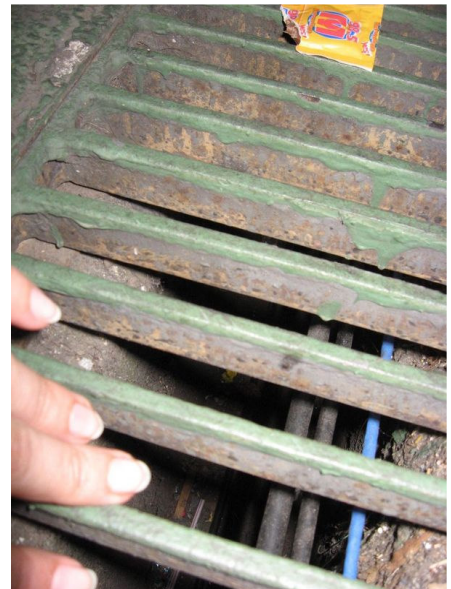

Figura 236 - detalhe de vãos em grelha.

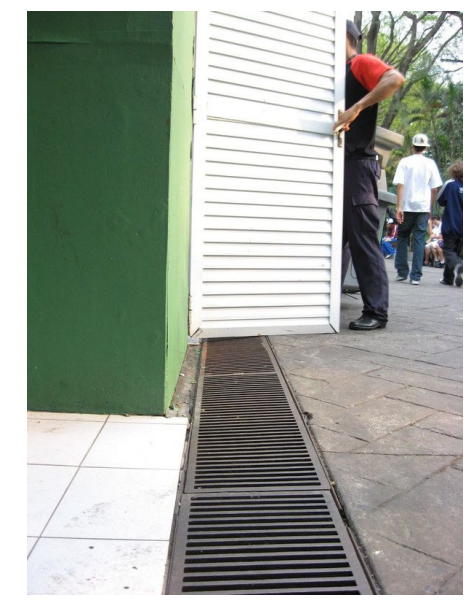

Figura 235 - grelha a ser trocada.

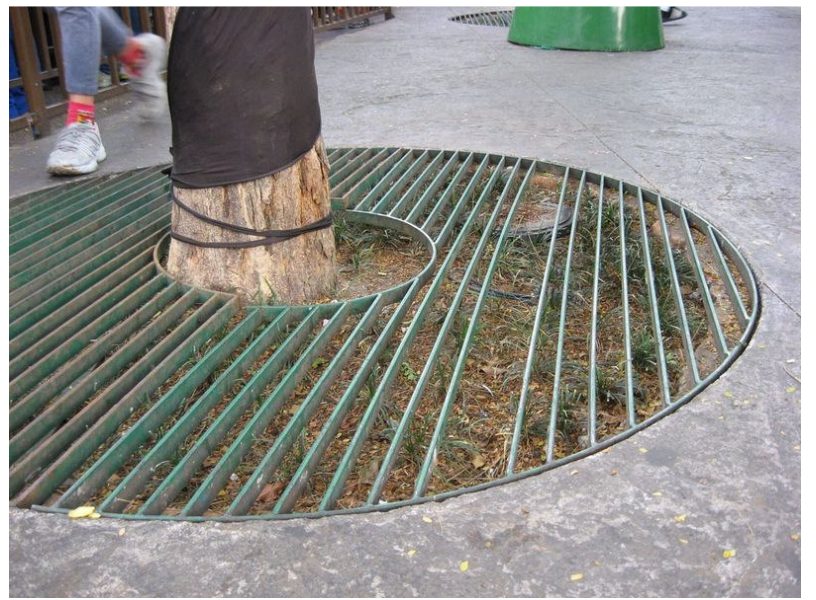

Figura 237 - grelha instalada para a vegetação. 
O primeiro brinquedo visitado foi a Barca Viking. O acesso normal é feito por um labirinto de gradil, seguido por uma escada e uma ponte.

Para um cadeirante ter acesso a esse mesmo brinquedo, a entrada é feita através da fila do Splash (outro brinquedo), em seguida atravessar o canal de água, por uma ponte de madeira removível, e o percurso seguinte é feito sobre outra ponte que leva à saída da Barca, onde o cadeirante poderá, então, entrar com o auxílio de um dos monitores do Playcenter.

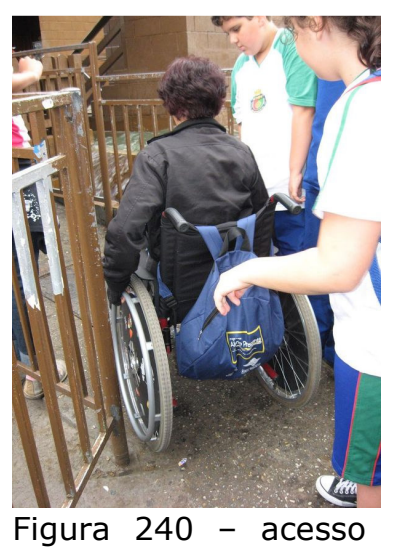

pela fila do Splash.

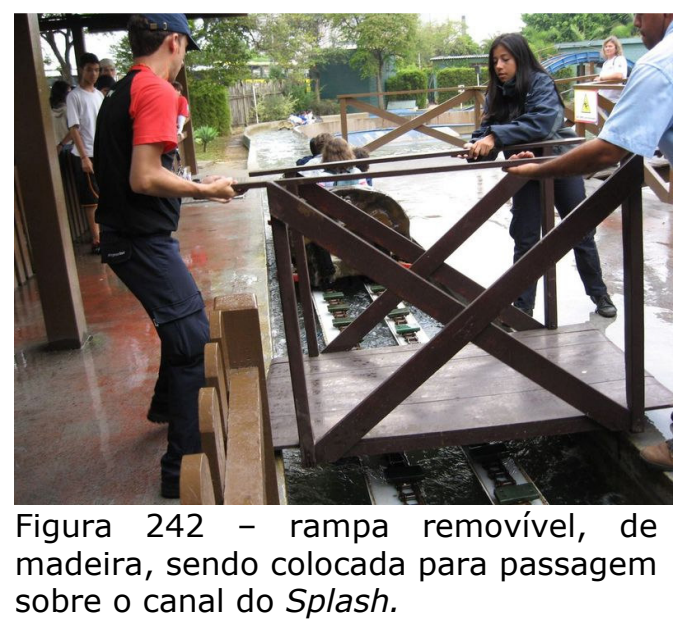

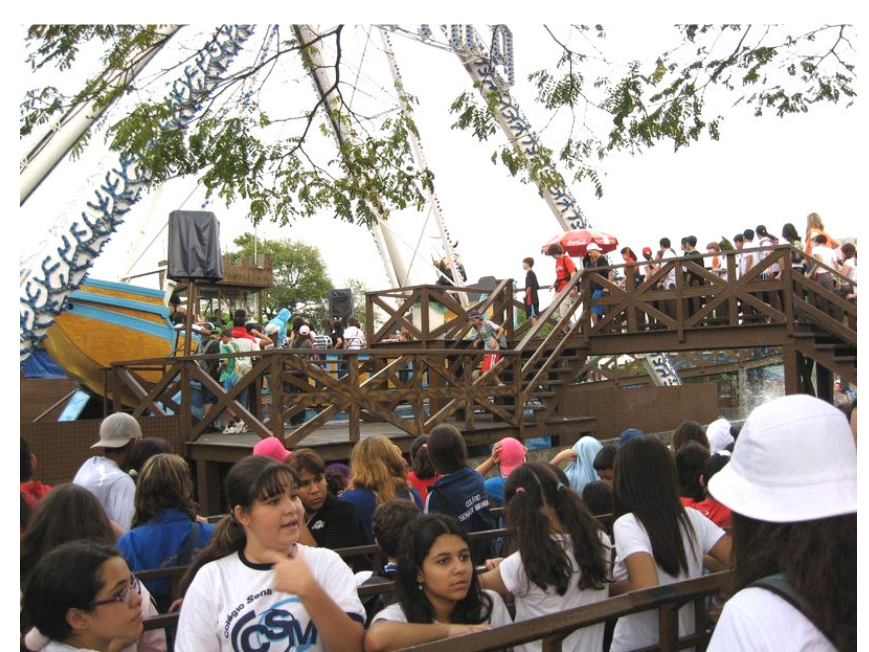

Figura 239 - labirinto de gradil e escadaria de acesso à Barca Viking.

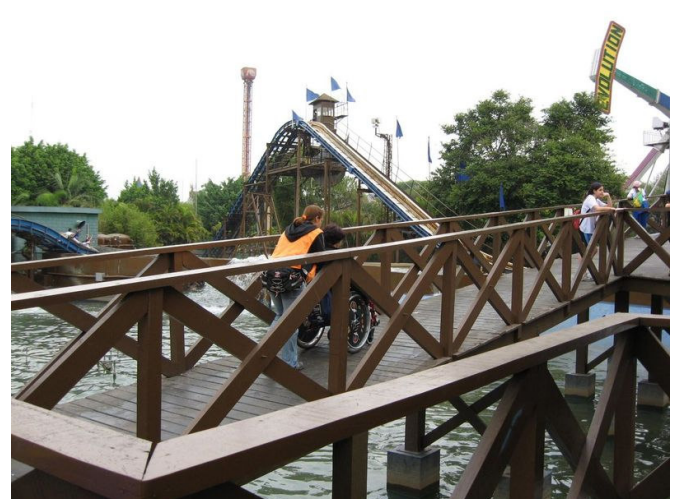

Figura 243 - ponte que leva à saída da Barca Viking.

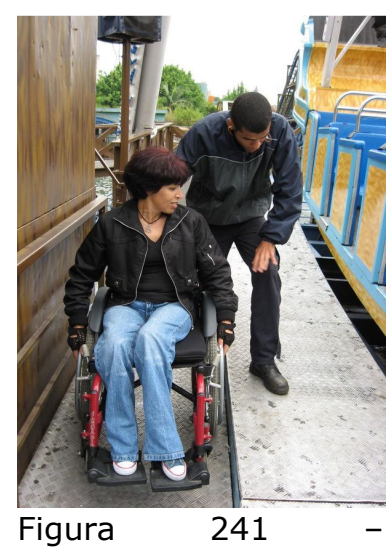

funcionário fazendo o translado da cadeirante para a Barca. Entrada pela saída do brinquedo. 
A entrada do sanitário, próximo à Barca Viking, possui rampa de acesso com inclinação adequada e piso tátil de alerta nas mudanças de nível. A coloração contrastante nos limites dessa rampa auxilia na orientação de pessoas com deficiência visual. Corrimãos foram instalados nas laterais, em duas alturas, como exige a Norma, porém não se podem deslizar as mãos continuamente sobre eles, por conta das hastes de sustentação.

$\mathrm{Na}$ entrada dos sanitários existem bebedouros posicionados em duas alturas, atendendo aos parâmetros da NBR9050/2004.

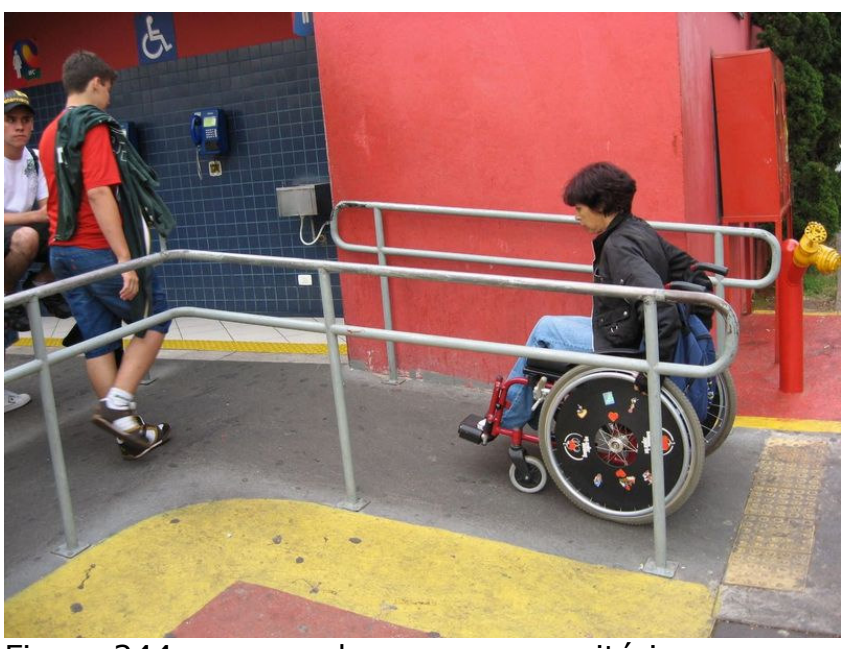

Figura 244 - rampa de acesso ao sanitário.

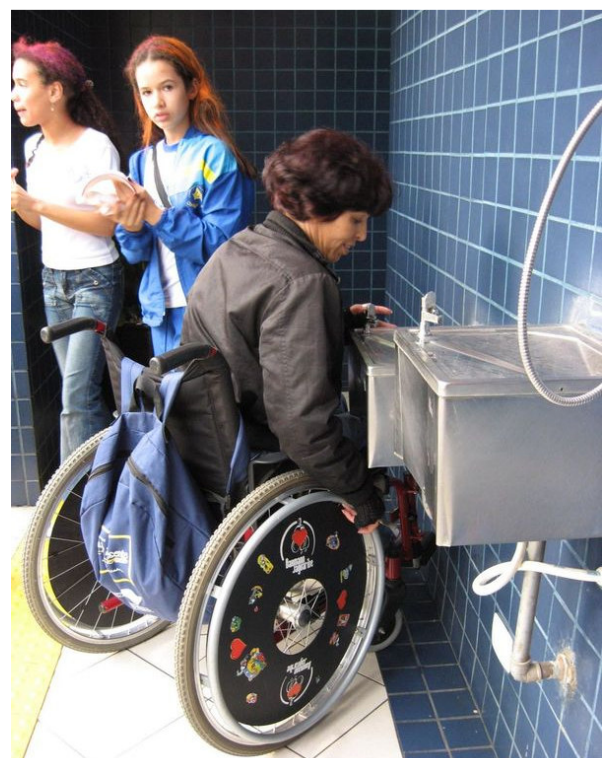

Figura 245 - bebedouro em frente ao sanitário. 


\section{Internamente, um dos sanitários visitados estava com a} cabine, destinada às PCDs, trancada. Foi necessário solicitar o acesso a uma funcionária presente no local. Infelizmente esta situação se repete em muitos locais em toda a cidade.

A cabine mencionada era corretamente dimensionada, tanto no uso do vaso sanitário, com as barras de apoio instaladas dentro dos parâmetros da Norma, como também o lavatório, espelho, papéis e sabonetes. Porém, de acordo com o Decreto Federal No. 5296 de 2004, a entrada dos sanitários acessíveis deve ser independente dos demais.

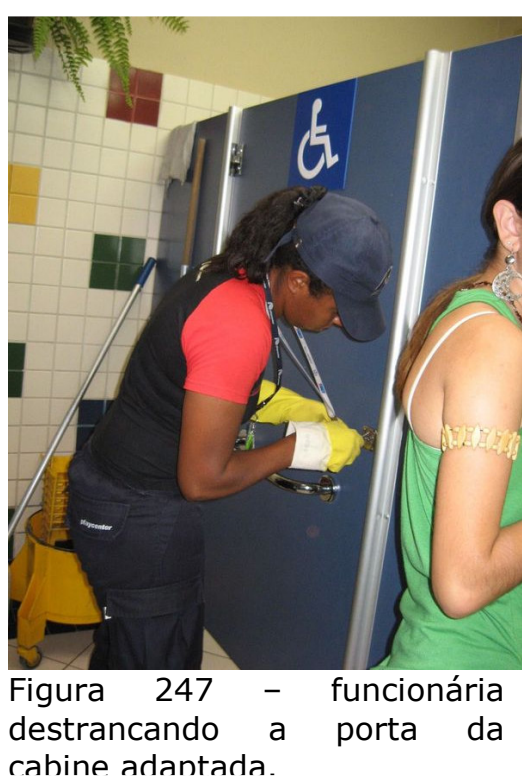

cabine adantada.

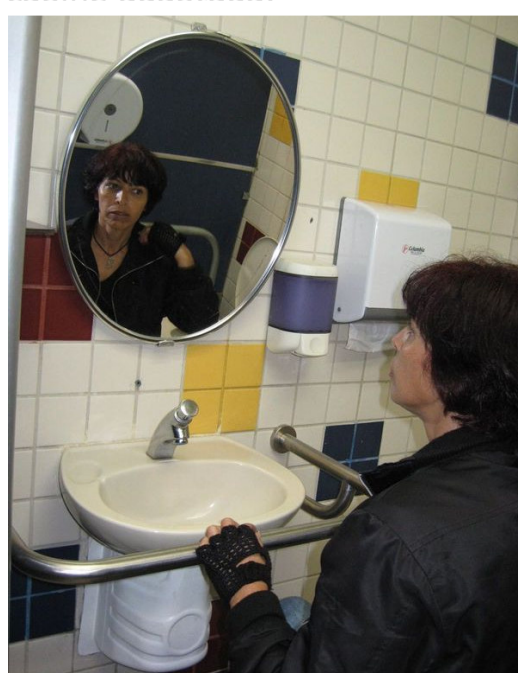

Figura 246 - instalações

dentro da cabine, de banheiro, adaptada. 
Continuando o roteiro percorrido, a caminho da Roda Gigante, o piso ainda não havia sido reformado, a nova versão será em concreto estampado. Na foto, é interessante observar a faixa amarela demarcando esse caminho. Essa faixa poderia ser mantida e reforçada com piso tátil direcional em todo o parque, facilitando o percurso de pessoas com deficiência visual.

A Roda Gigante não possui restrição de uso para cadeirantes, porém seu acesso só pode ser feito com auxilio dos monitores do Playcenter, para efetuar o translado, pois existem quatro degraus para o embarque e o próprio "cesto" não comporta cadeiras de rodas.

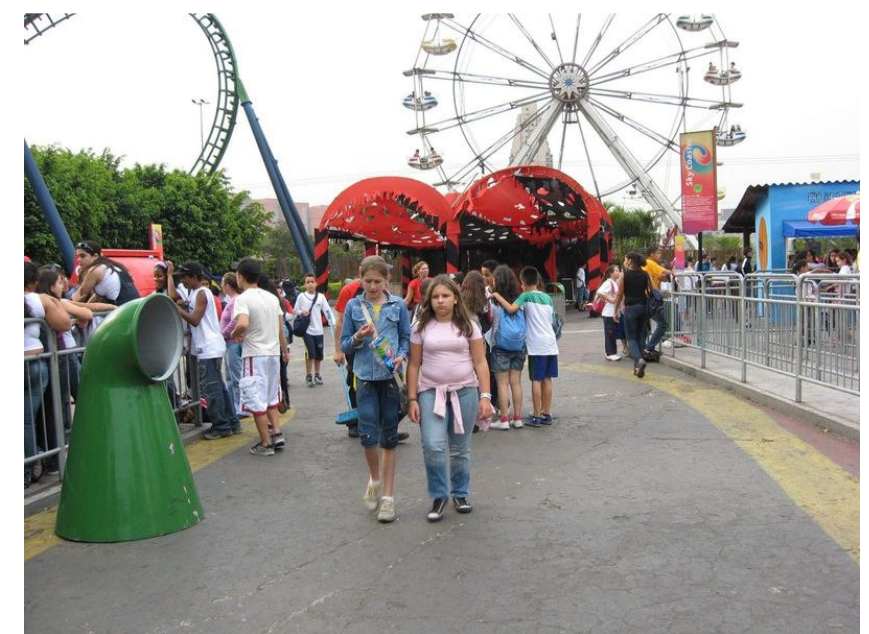

Figura 248 - caminho para a RodaGigante.

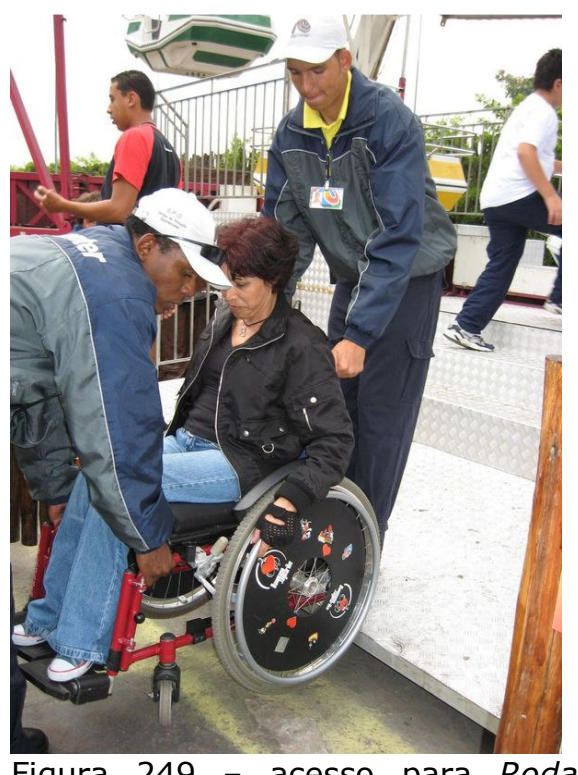
Gigante. 
Há quiosque de venda de alimentos espalhados ao longo de todo o parque e não apresentam desenho que atenda às pessoas em cadeiras de rodas. Os balcões possuem altura superior a 0,90m, recomendado pela Norma. Além disso, um degrau que circunda o atendimento impede a aproximação para o contato com a atendente.

Os caminhos reformados estão em boas condições de circulação. Restam alguns espaços que ainda serão refeitos.

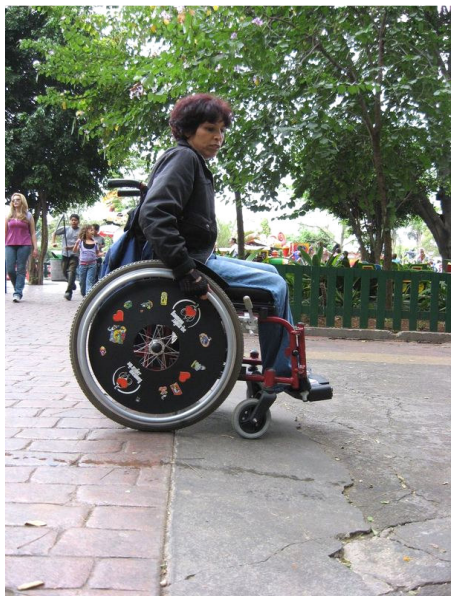

Figura 252 - limite entre o piso reformado e o antigo.

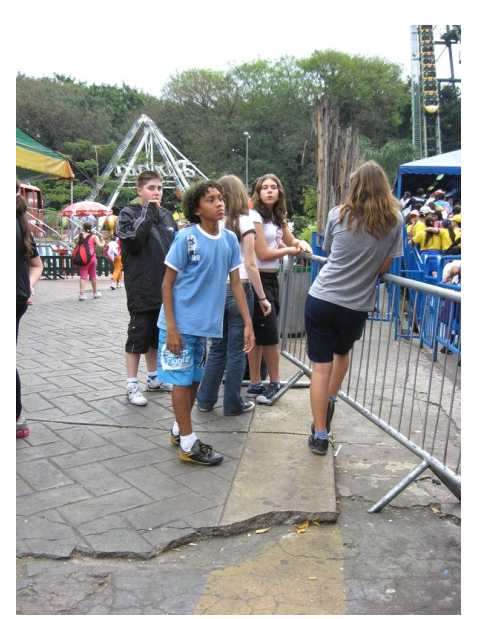

Figura 251 - buracos no piso antigo.

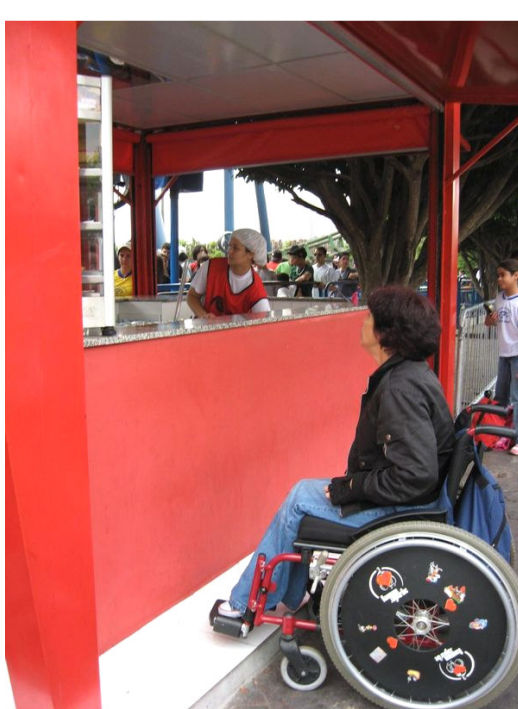

Figura 250 - quiosque de venda de alimentos.

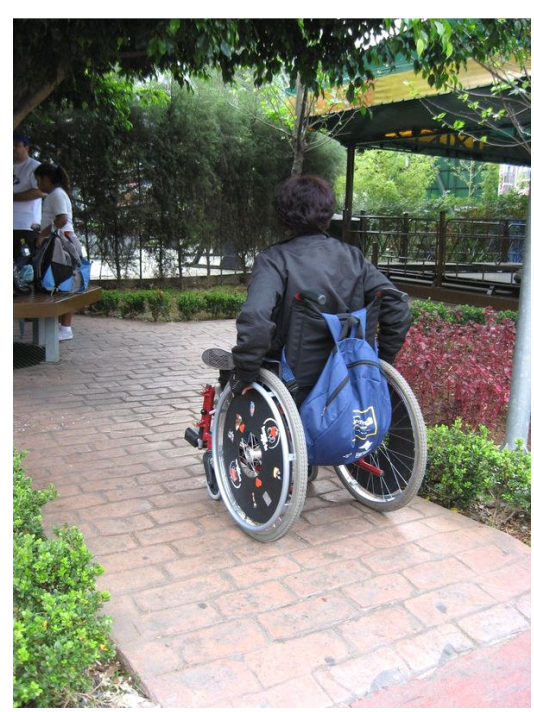

Figura 253 - caminho reformado. 
Atrás da praça de alimentação, existe um acesso a uma área que, durante a noite, funciona como "carceragem de monstros" das Noites do Terror. Para chegar até lá, existe uma rampa extremamente íngreme, que não permite ao cadeirante subir com autonomia. Não possui sinalização tátil, nem corrimãos em duas alturas, como exige a Norma.

$\mathrm{Na}$ praça de alimentação, prosseguindo o roteiro, as mesas fixas, observadas na visita anterior, foram mantidas. Essas mesas apresentam problemas em relação à altura e ao encaixe da cadeira de rodas sob elas.

As novas mesas são móveis e a altura do tampo está entre os 0,75m e 0,85m (de acordo com a NBR9050/2004), porém a largura entre seus pés é inferior a 0,80m, dificultando a aproximação.

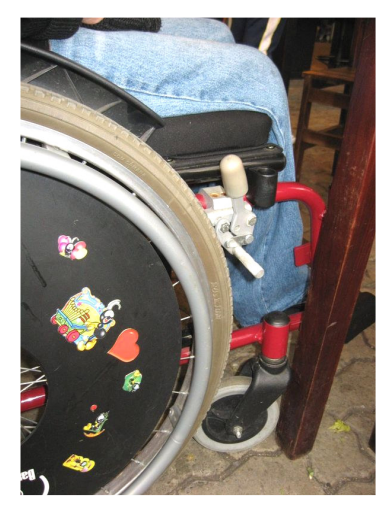

Figura 256 - detalhe do encaixe da cadeira de rodas sob a mesa.

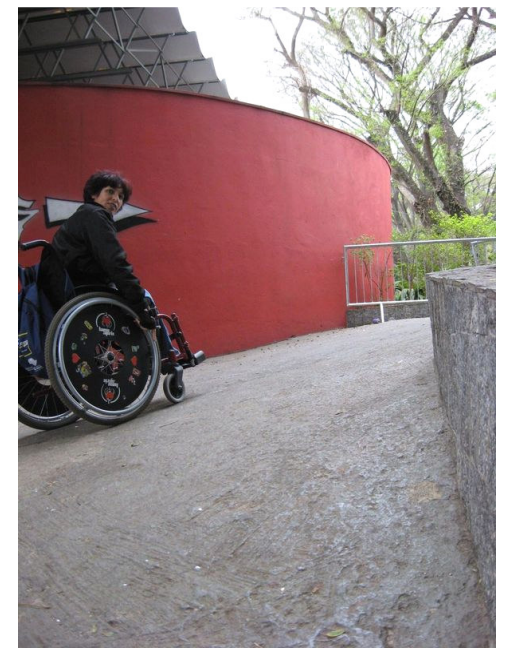

Figura 255 - rampa íngreme, sem sinalização e corrimãos, no acesso à "carceragem de monstros".

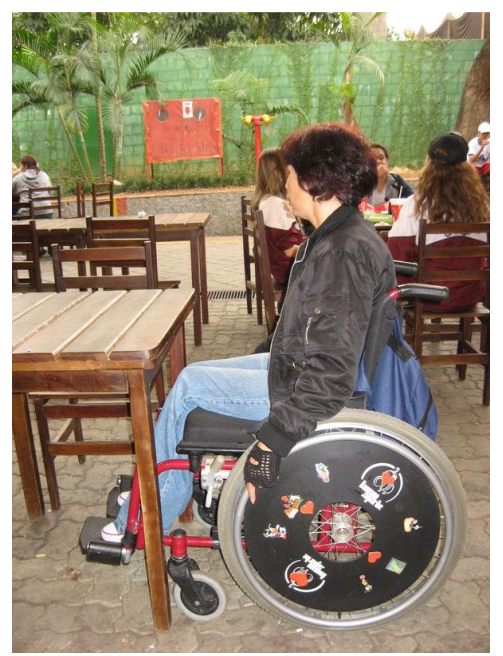

Figura 254 - aproximação em relação às mesas móveis, da praça de alimentacão.. 
Da praça de alimentação para a área de eventos existe uma passagem fechada sobre 0 córrego, que corta 0 parque. A transposição é elevada e para isso existem rampas em ambos os lados. As rampas possuem sinalização tátil e corrimãos em duas alturas, como exige a Norma. Porém, a inclinação é superior aos $8,33 \%$ e os corrimãos não permitem a empunhadura contínua durante o percurso.

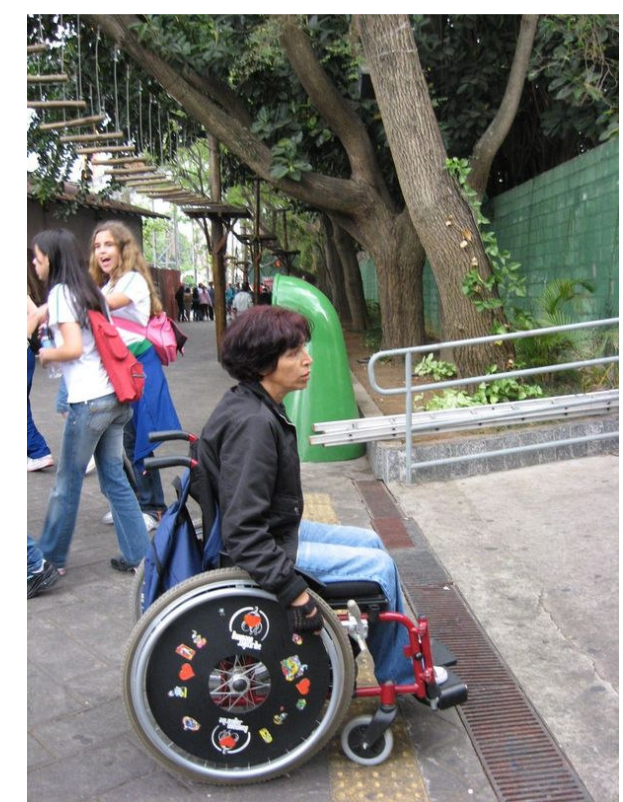

Figura 259 - rampa de passagem sobre o córrego.

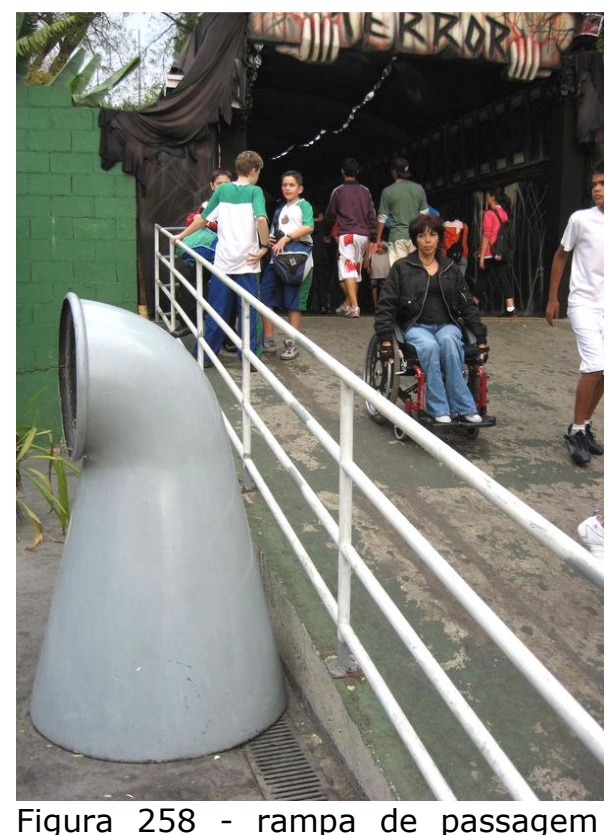

sobre o córrego.

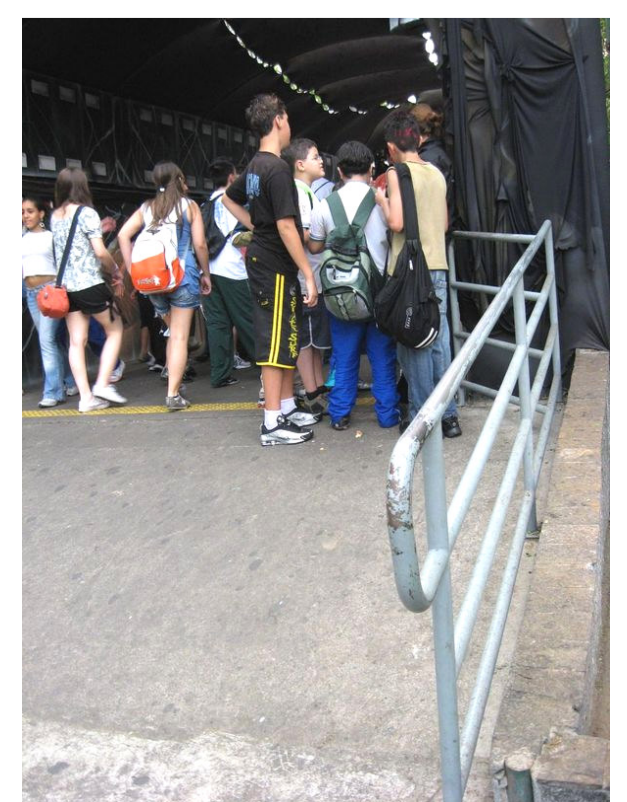

Figura 257 - rampa de passagem sobre o córrego. 
Considerando o roteiro, após a rampa, o Magic Motion foi a atração seguinte. Trata-se de um local para projeção em 3D e para acessá-lo é preciso subir uma extensa e íngreme rampa circular. 0 guarda-corpo possui corrimãos em 3 alturas, porém nenhuma das posições atende aos parâmetros da NBR9050/2004, por isso, não é possível utilizá-los como ferramenta de impulsão na subida, pois não permitem a aplicação de maior força do cadeirante.

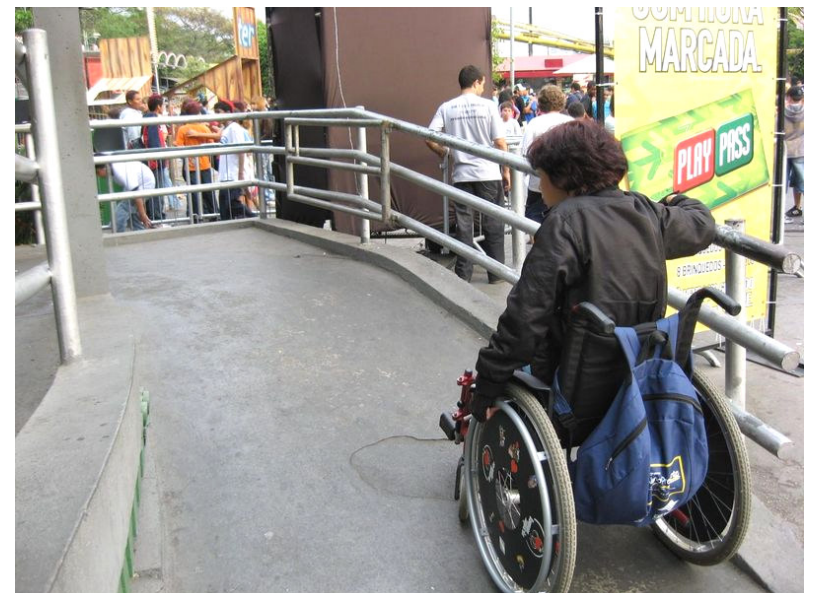

Figura 260 - rampa de acesso ao Magic Motion.

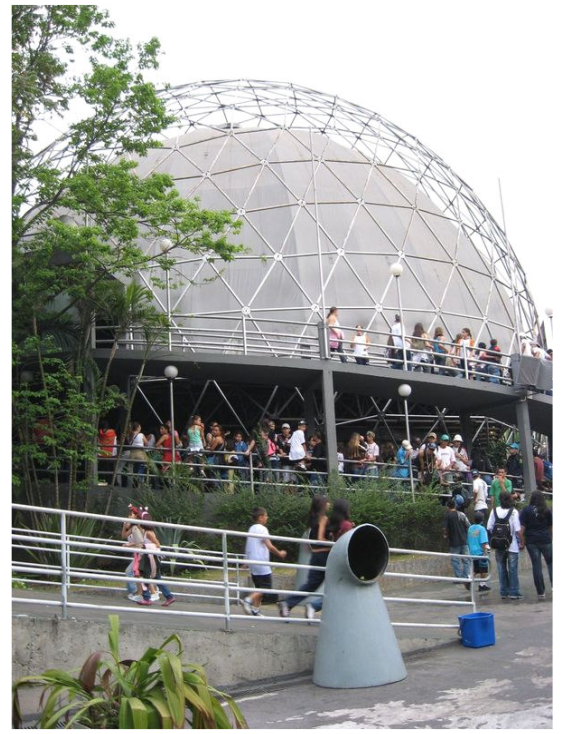

Figura 262 - Magic Motion.

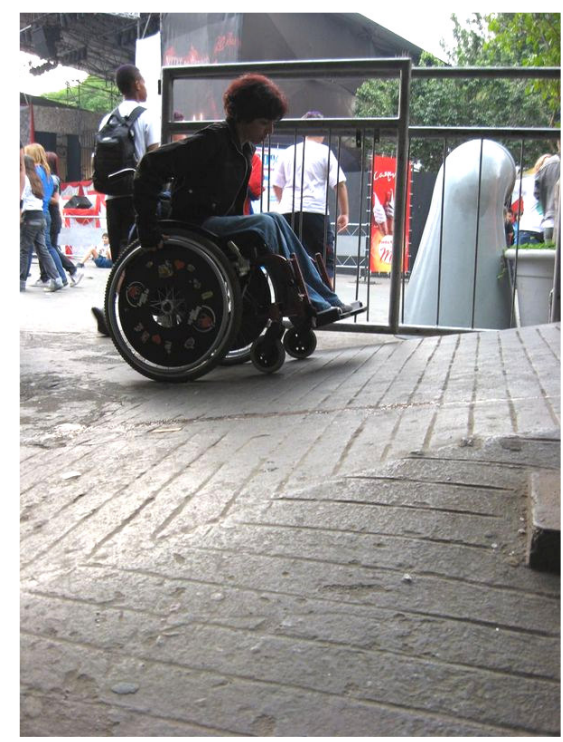

Figura 264 - início da subida da rampa do Magic Motion.

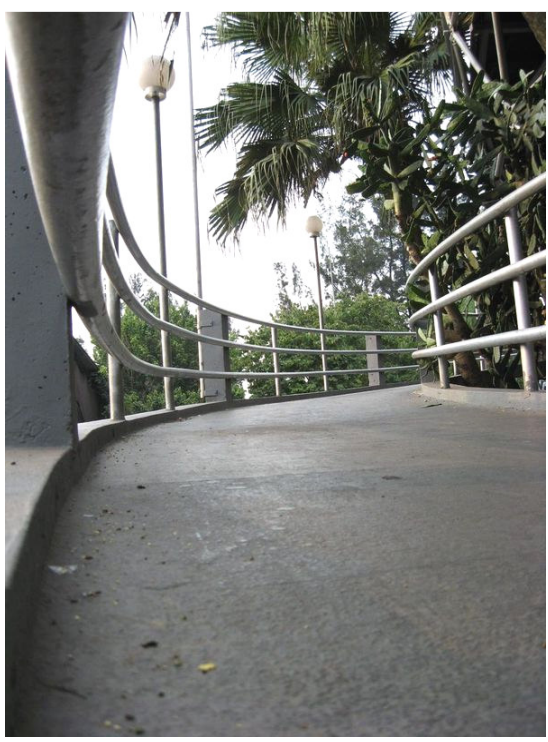

Figura 263 - rampa do Magic Motion.

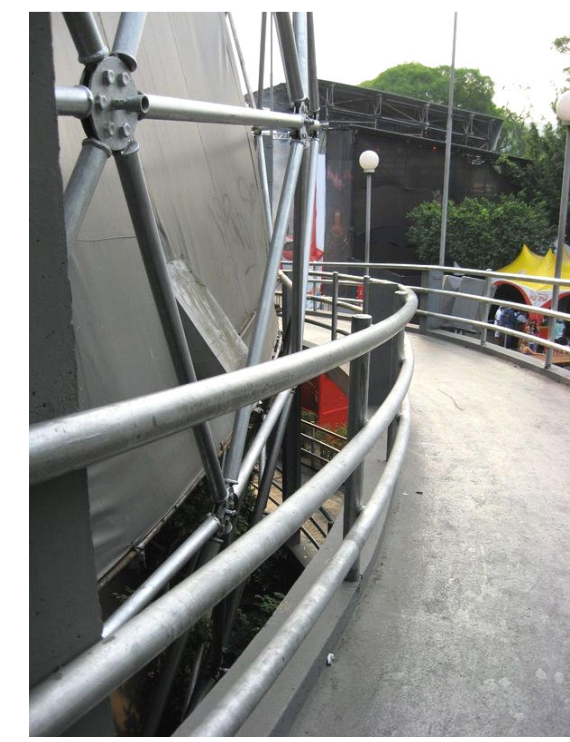

Figura 261 - rampa do Magic Motion. 
Ao subir a rampa, o local da projeção possui acomodações que se movimentam e simulam as sensações do filme apresentado. Para cadeirantes, é possível ficar à frente da platéia, quase sob a tela de projeção. Nesse local, pode-se permanecer na própria cadeira de rodas ou transladar-se para as acomodações reservadas, as quais são fixas e não se movimentam como as demais. Se o cadeirante desejar, um dos monitores o carregará até a parte superior da platéia, que é acessada por degraus. Coloca a pessoa nas cadeiras articuladas, junto com as demais.

As cadeiras articuladas possuem cintos de segurança de dois pontos, na região da cintura. Caso uma pessoa com paralisia dos membros superiores quisesse participar, não poderia, a menos que os cintos fossem redesenhados para mantê-la fixa à cadeira.

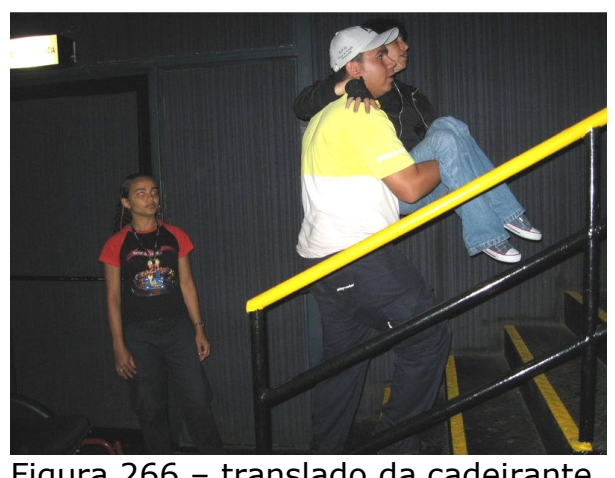

Figura 266 - translado da cadeirante para os assentos da platéia.

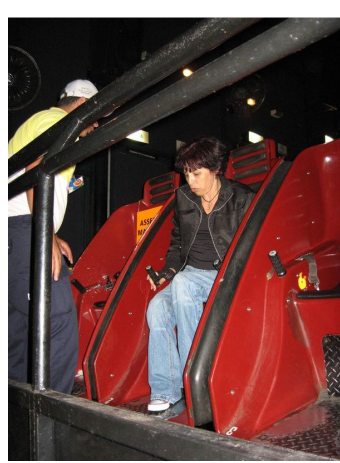

Figura 267 -

Cadeiras articuladas

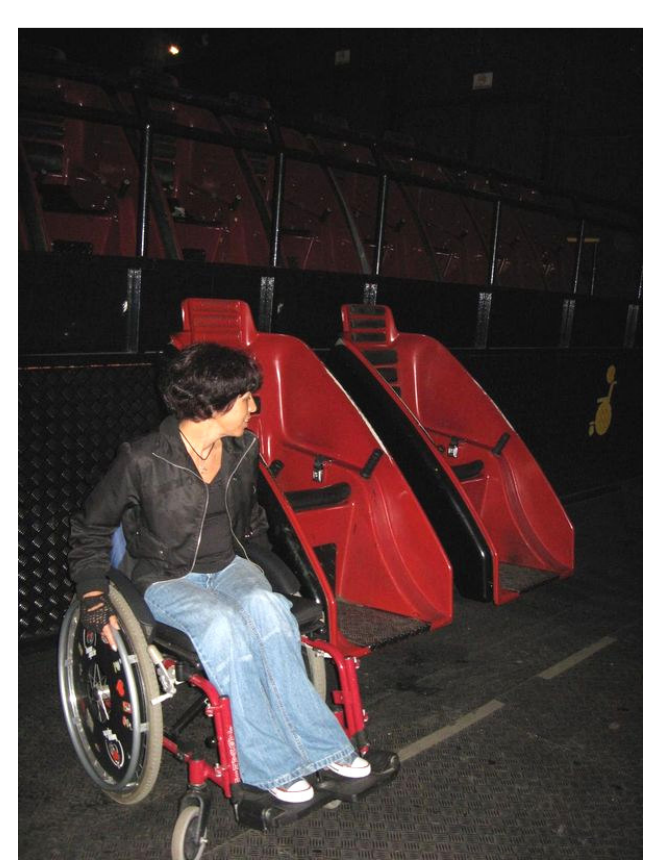

Figura 265 - Acomodações para cadeirantes 
Continuando a visita, na saída do Magic Motion, o balcão do quiosque de churrasco não atende aos parâmetros da Norma. Sua altura é incorreta e não há espaço sob ele, que permita a aproximação, como explicado anteriormente.

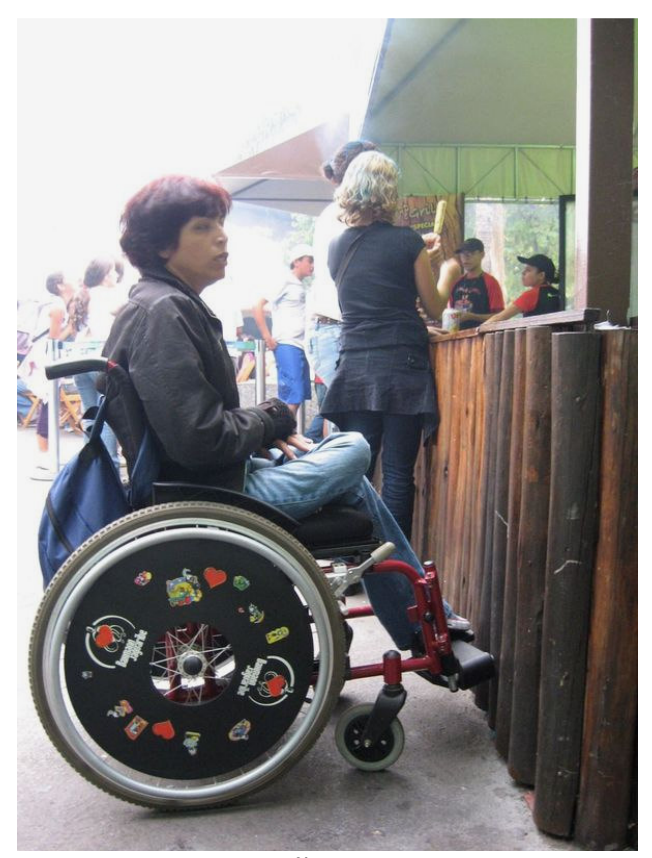

Figura 268 - balcão do quiosque de churrasco. 
A Wind Storm foi a única montanha russa visita nesse roteiro. Dentro das restrições mencionadas no início do percurso, essa não foi uma das atrações proibidas. Para entrar nesse brinquedo, existe uma rampa lateral, com guarda-corpos sem corrimãos contínuos e sem sinalização tátil nas mudanças de nível.

Foi solicitado, na entrada do brinquedo, o termo de permissão. A cadeirante não foi colocada no carrinho, pois nessa atração foi orientada para que o fizesse sozinha e exigiu-se a companhia do responsável. Ao sair, a cadeirante refez o translado e seguiu o mesmo caminho da entrada, que é a saída das demais pessoas.

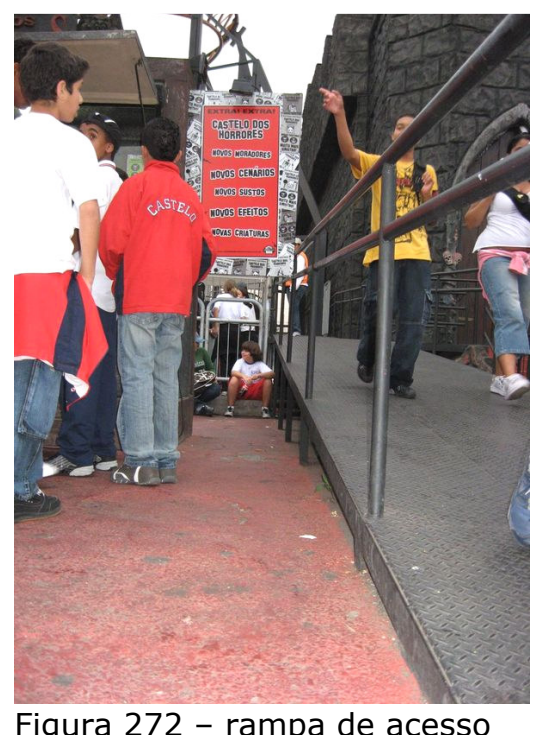

à Wind Storm.

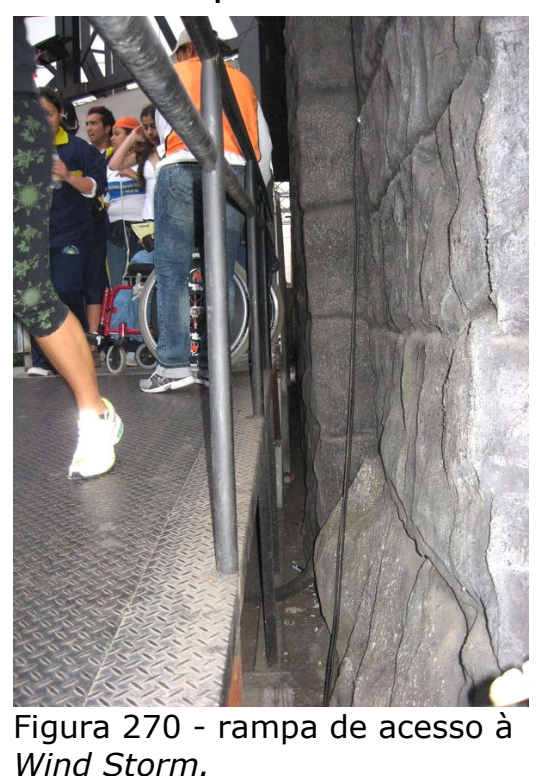

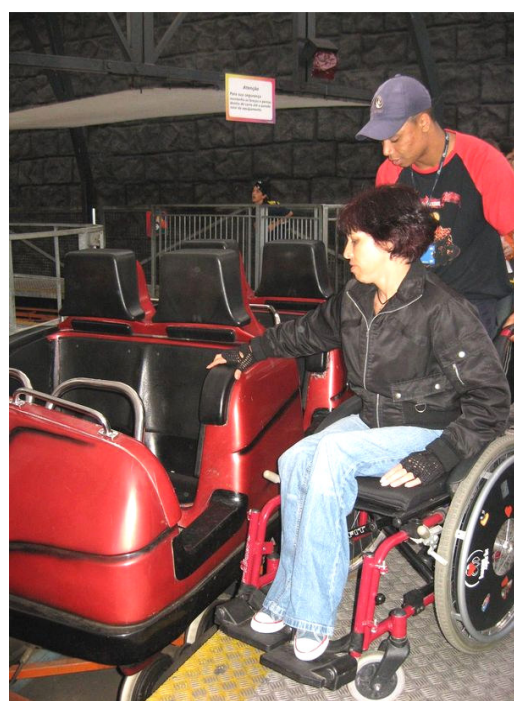

Figura 269 - entrada para 0 carrinho da Wind Storm.

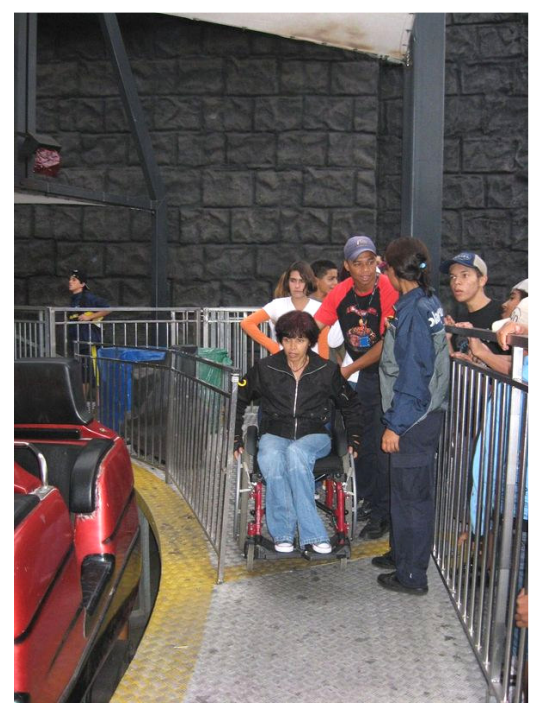

Figura 271 - plataforma de embarque para a Wind Storm. 
Ao sair da atração a próxima parada foi no sanitário da área de eventos. Este estava corretamente sinalizado com piso tátil de alerta nas mudanças de nível, possuía indicação de banheiro acessível e a porta da cabine adaptada estava corretamente destravada. Segundo o Decreto 5296 de 2004 os banheiros para PCDs devem possuir entradas independentes das demais pessoas. Embora sejam banheiros aparentemente novos, não atenderam esta recomendação.

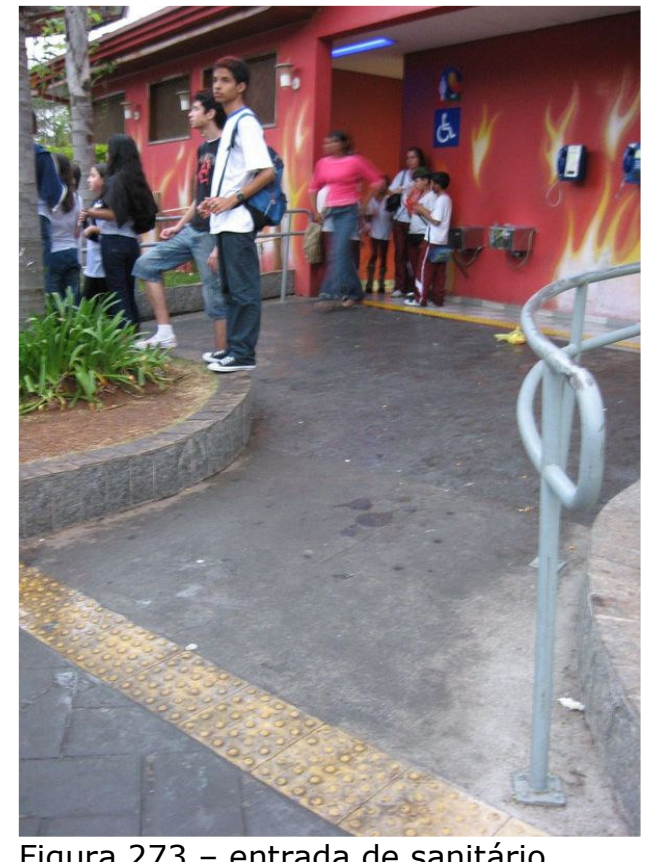

Figura 273 - entrada de sanitário. 
A última atração visitada foi ainda durante o dia, o Wave Swinger, o qual fica em nível elevado e possui cadeiras suspensas que giram, e não são aceitas pessoas que possuam próteses.

O acesso a esse brinquedo é feito por escadas e a cadeirante foi carregada no colo até a cadeira do brinquedo. Ao sair, novamente, o monitor fez o mesmo trajeto, com a visitante nos braços.

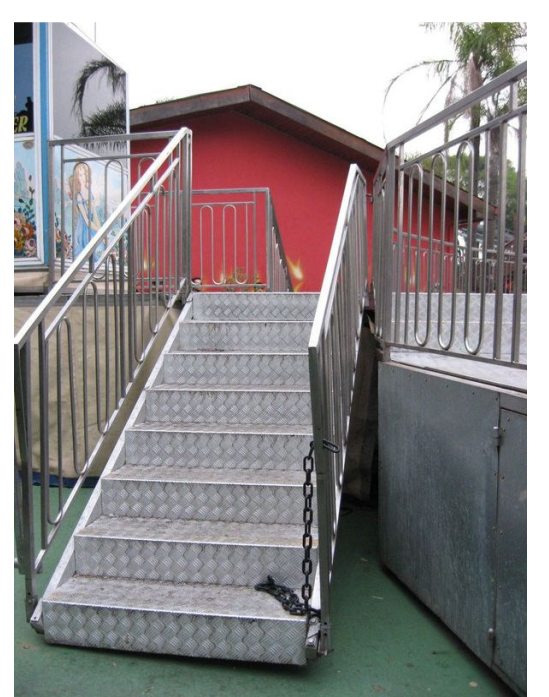

Figura 277 - escada de acesso à plataforma do Wave Swinger.

Acessibilidade à Paisagem Daniela Vaz

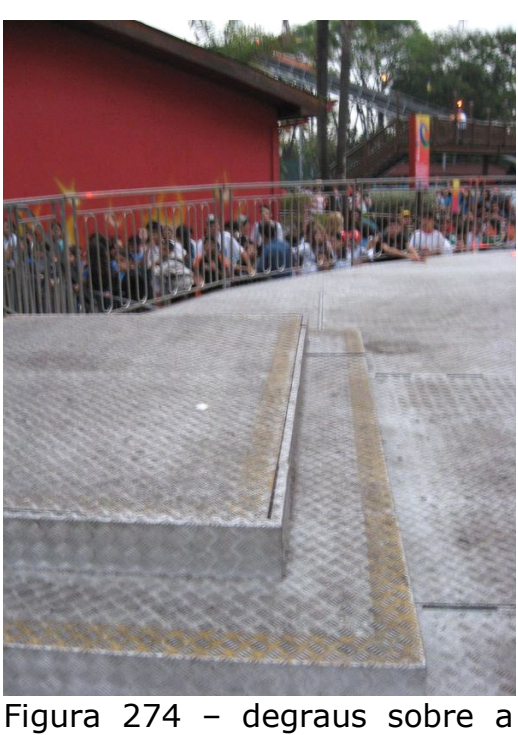

plataforma do Wave Swinger.

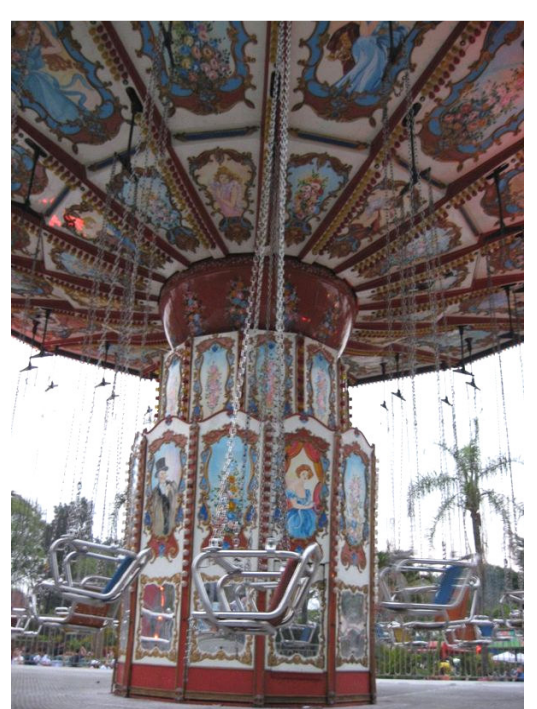

Figura 275 - Wave Swinger.

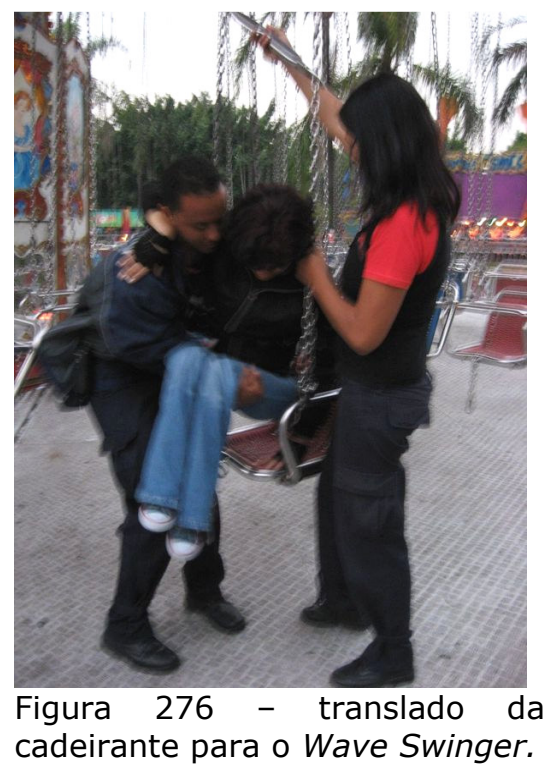

Página 248 
Durante à noite, nas Noites do Terror, é apresentado elenco de atores fantasiados de monstros, iluminação cenográfica e trilha sonora especialmente preparada para compor o clima de "horror".

O roteiro foi refeito ao escurecer, porém, dessa vez, as atrações visitadas foram outras. Não houve o ingresso em qualquer brinquedo mecânico e sim em ambientes que compunham o circuito do evento. Estes eram planos ou acessados por rampas. Os monitores foram muito atenciosos, evitando acidentes como, por exemplo, choque entre visitantes assustados com os "monstros" inesperados e a cadeirante. 


\section{Considerações finais - Playcenter}

O parque Playcenter possui condições territoriais favoráveis para a implantação de acessibilidade. O terreno é plano e amplo, facilitando o desenho de rotas acessíveis. No entanto, o empreendimento evoluiu ao longo de sua história, sem planejamento espacial integrado com este conceito. Em relação aos brinquedos, tantos os novos como os antigos, também não atendem a estas questões.

Após as imposições dos prazos do Decreto 5.296 de 2004, o Playcenter passou a se preocupar mais diretamente com as condições de acessibilidade do parque. Sem dúvida, os ganhos com relação a este tema foram inúmeros. Atualmente, é possível que PCDs circulem por todo o parque e utilizem todos os equipamentos que estejam relacionados à construção civil. Alguns ajustes ainda seriam necessários para que fossem ampliados os quesitos de acessibilidade, segurança e conforto, especialmente em relação aos corrimãos, balcões, escadas e sinalização. O piso está sendo reformado aos poucos, dentro da logística de funcionamento do parque.

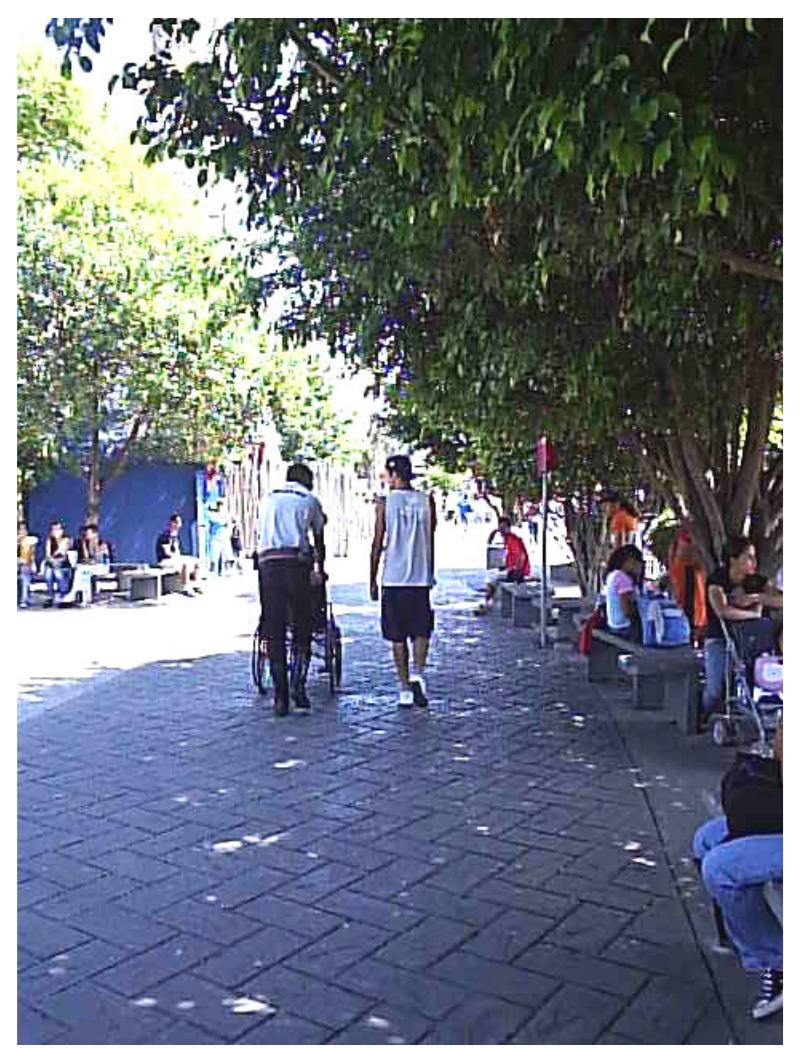

Figura 278 - Monitor levando cadeirante. 
Os brinquedos continuam tendo complicações dentro deste contexto, pois apresentam uma série de restrições, não apenas de acessibilidade (de acesso), mas também de uso, pois, ou a atividade inviabiliza o uso (ex. arvorismo), ou podem representar riscos para determinados tipos de deficiências (ex. montanha russa para pessoas com deficiência mental).

O atendimento dos funcionários do parque foi excelente. Todos foram muito atenciosos e de boa vontade. Garantiram a prioridade da cadeirante nas filas, apresentaram orientação para todos os questionamentos e viabilizaram o ingresso em todas as atrações visitadas.

Faltou guia impresso em Braile e mapa tátil, contendo informações para que pessoas com deficiência visual pudessem orientar-se, autonomamente.

A busca de ganhos de imagem social está fazendo com que o Parque desenvolva ações de integração de PCDs, de forma mais inclusiva, em suas atividades. No entanto, outras alterações precisam ser executadas, visando complementar o programa e garantir que as PCDs, que pretendam visitar o Playcenter, o façam de forma autônoma e descontraída.

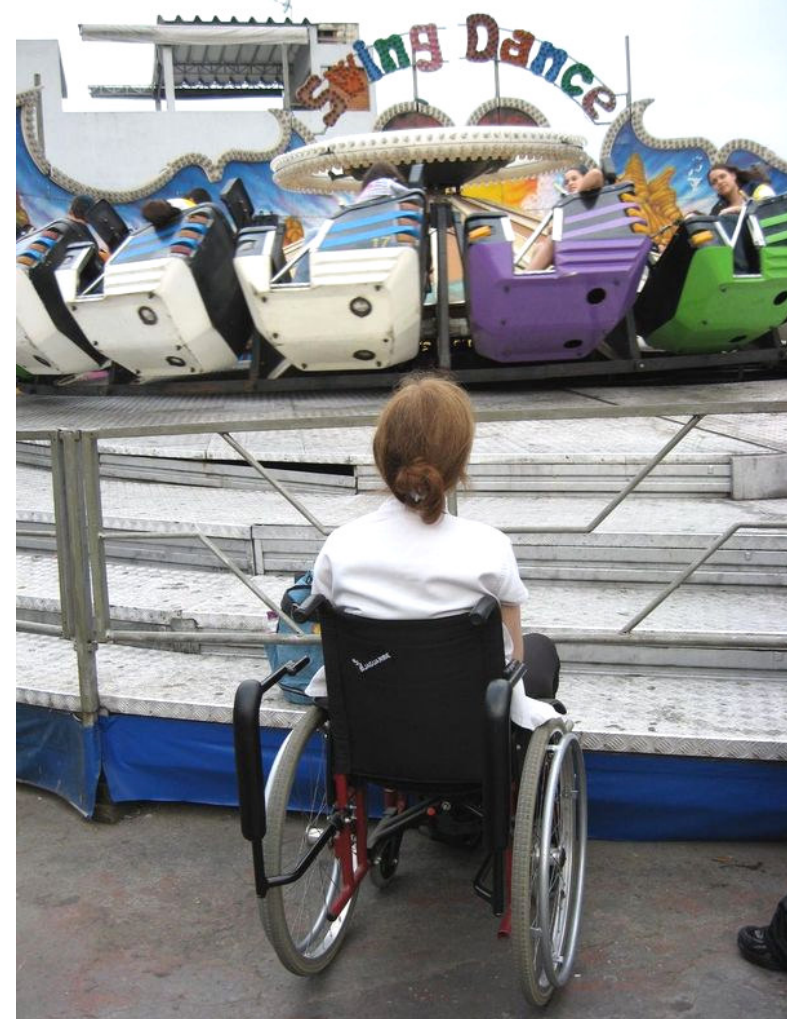

Figura 279 - visitante do Parque, cadeirante, em frente aos degraus de acesso ao Swing Dance. 


\section{Considerações Finais}

Esta dissertação apresentou estudo de avaliação das condições de acessibilidade em espaços livres públicos ou espaços privados de uso coletivo. Essas análises demonstraram aspectos não apenas técnicos e normativos, mas também um panorama de como a questão incorporou-se aos projetos, com que qualidade e em que medida avançou dentro do contexto da inclusão social.

Os estudos desenvolvidos demonstraram que, embora ao longo da história do desenho paisagístico, a acessibilidade, geralmente, não tenha sido incorporada, os projetos avaliados representam avanços na prática do desenho universal.

Esse avanço deu-se após a inserção desses conceitos nos projetos internacionais e após exigências legais, que surgiram de movimentos reivindicatórios. No entanto, os estudos descritos neste trabalho, de modo geral, representam projetos que foram além do aspecto legalista, resultando em espaços inclusivos e agradáveis.

O direito à cidade está longe de ser estendido a todos os cidadãos. Os estudos de casos apresentados são fragmentos de espaços preocupados com a acessibilidade, entretanto, não 
representam um sistema que atenda a cidade toda. A acessibilidade plena, ainda não foi alcançada, e para tanto os projetistas têm a obrigação de desenharem espaços universalmente acessíveis, viabilizando um conjunto integrado.

Dentro desse contexto, o presente trabalho buscou contribuir com análises do espaço livre público ou de uso coletivo, voltados à acessibilidade. A importância deste tema está no fato de que o espaço não edificado representa a possibilidade de acesso aos espaços construídos. Se aquele for universalmente acessível, a cidade oferecerá a oportunidade de acesso a todas as pessoas, inclusive ao meio construído.

Para atingir o objetivo dos espaços universalmente acessíveis, o conceito do desenho universal é importante, pois busca atender ao maior número possível de pessoas, sem distinção. Se este conceito for incutido nos arquitetos, então, poderão surgir espaços de qualidade para todos.

Após as análises dos espaços livres - Calçadas, Praça da Sé e Playcenter - o que se pode notar é que o primeiro passo foi dado. Estes estudos apresentam espaços, que de alguma forma, por força de lei ou motivos econômicos, começaram a atentar para a questão. 
Ainda não apresentam, de modo geral, condição ideal de aplicação de conceitos de acesso universal, porém sinalizam o início deste processo e da maneira como estão, caracterizam espaços de qualidade muito superior aos espaços que não lidam com a acessibilidade, representando ganhos sociais de inclusão.

Os espaços analisados foram adaptados atendendo aos interesses de diferentes agentes - a iniciativa privada ou o poder público - e projetadas por arquitetos. Confirmando que existe a demanda por trabalhos neste sentido.

Seja pelo despertar da consciência, de parte da sociedade, pela questão, seja por força de lei, ou seja, por interesses econômicos, o fato é que os espaços livres também estão sendo gradativamente adaptados ao acesso universal.

Cumpre agora iniciar a discussão da qualidade dessas adaptações, o mérito dos espaços resultantes.

Vale reforçar, ainda, que os projetos que incorporaram os conceitos do desenho universal, como a Praça da Sé, por exemplo, resultaram em propostas de qualidade muito superior às demais, pois 
a concepção apresenta papel fundamental nas conquistas de espaços confortáveis, seguros e acessíveis.

Como dito ao longo do presente trabalho, "a deficiência pode, de fato, segregar pessoas impactando de forma negativa a vida pessoal, social e profissional, no entanto, esse impacto pode ser minimizado ou mesmo dirimido em situações, ambientes e atitudes que levem em consideração as potencialidades do indivíduo e não suas limitações", por isso, a importância de criarem-se espaços universamente acessíveis.

Esta dissertação procurou contribuir, então, para o entendimento do desafio, que a acessibilidade estabelece, e com a mudança dos paradigmas e procedimentos, para quem trabalha com o projeto dos espaços livres. Mudanças que devem pautar não só a prática profissional dos arquitetos, como a formação dos novos profissionais. 


\section{Referências}

Acessibilidade para Todos: uma cartilha de orientação. Rio de Janeiro. Coord. Duarte, C.R. e Cohen, R., Núcleo Pró-Casso, UFRJ/FAU/PROARQ, 2004.

AMERICANS WITH ACT DISABILITIES COMPLIANCE - A PRACTICAL GUIDE. Birmingham, Alabama, Evan Terry Associates, PC, Editora John Willy \& Sons, 1993.

ANAIS DO SEMINÁRIO ACESSIBILIDADE NO COTIDIANO. Rio de Janeiro, Universidade Federal do Rio de Janeiro, Faculdade de Arquitetura e Urbanismo, Programa de Pós-graduação em Arquitetura, Núcleo Pró-acesso, Universidade Veiga de Almeida, Escola de Design, 2004.

ASSOCIAÇÃO BRASILEIRA DE NORMAS TÉCNICAS. ABNT. Acessibilidade a edificações, mobiliário, espaços e equipamentos urbanos - NBR 9050/2004. Rio de Janeiro: ABNT/Fundo Social de Solidariedade do Estado de São Paulo, 2004.

Avaliação Pós-Ocupação: métodos e técnicas aplicados à habitação social / Editores e Coordenadores: Marcelo de Andrade Roméro e Sheila Walbe Ornstein. Porto Alegre : ANTAC, 2003. -- (Coleção Habitare)

BAHIA, Sergio Rodrigues; COHEN, Regina; VERAS, Valéria. Município e Acessibilidade. Rio de Janeiro, IBAM/DUMA, 1998.

BARTALINI, Vladimir. Praças do Metrô: Enredo, Produção, Cenário, Atores. São Paulo, Dissertação de Mestrado FAU-USP, 1988.

BEDNAR, Michael J.. Barrier-free environments. Virginia, Editora Dowden, Hutchinson \& Ross, 1977.

BODSTEIN, Regina; RAMOS, Célia Leitão Ramos; HORTALE, Virgínia Alonso. Programa de Reabilitação Comunitária - Experiência de Inclusão Social da Pessoa Portadora de Deficiência. FUNLAR. Rio de Janeiro, Prefeitura do Rio de Janeiro - 2003.

BURJATO, Ana Lúcia Pinto de Faria. Parques acessíveis - um direito de cidadania. Aplicação de procedimentos para avaliação do projeto implantado o caso do Parque Villa Lobos. São Paulo, Dissertação de Mestrado, 2004. 
CAMBIAGHI, Silvana Serafino. Desenho Universal: Métodos e Técnicas de ensino na Graduação de Arquitetos e Urbanistas. São Paulo, Dissertação de Mestrado, 2004.

CÓDIGO DE TRÂNSITO BRASILEIRO. Disponível em: <http://www.transportes.gov.br/bit/trodo/codigo/index.htm> . Acesso em abril/2007.

COMISSÃO PERMANENTE DE ACESSIBILIDADE - CPA. Guia de Legislação para Pessoas portadoras de Deficiência ou com Mobilidade Reduzida. São Paulo, SEHAB - Secretaria da Habitação do Município de São Paulo, 2002.

COMISSÃO PERMANENTE DE ACESSIBILIDADE - CPA. Guia para Mobilidade Acessível em Vias Públicas. São Paulo, SEHAB - Secretaria da Habitação do Município de São Paulo, 2002.

COMPANHIA METROPOLITANA DE SÃO PAULO. Disponível em: <http://www.metro.sp.gov.br>. Acesso em abril/2007.

COMPANHIA METROPOLITANA DE SÃO PAULO. Disponível em:

<http://www.metro.sp.gov.br/servicos/terminais/barrafunda/barra.shtml > Acesso em abril/2007.

Contos Fantásticos do Século XIX: o fantástico visionário e o fantástico cotidiano. Organizado por Italo Calvino. São Paulo, Companhia das Letras, 2004.

COORDENADORIA NACIONAL PARA INTEGRAÇÃO DA PESSOA PORTADORA DE DEFICIÊNCIA (CORDE). Disponível:

<http://www.mj.gov.br/sedh/ct/corde/dpdh/sicorde/decl_pessoa def.asp>. Acesso em mar/2004.

CRUZ, Luciana Riemer da; BARRETO, Sidirley de Jesus. A Importância do Lazer na Inclusão da Pessoa Portadora de Deficiência Mental na Sociedade. Instituto Catarinense de Pós-graduação. Santa Catarina, 2003. Revista Leonardo Pós. Revista 2 jan. - jun..

DBTAC - National Network of ADA Centers. Disponível em: <http://www.adata.org>. Acesso em out/2007.

DECLARAÇÃO DOS DIREITOS DAS PESSOAS DEFICIENTES. Organização das Nações Unidas (ONU), 1975. Disponível em: portal.mec.gov.br/seesp/arquivos/pdf/dec_def.pdf. Acesso em abril/ 2007. 
DECLARAÇÃO UNIVERSAL DOS DIREITOS HUMANOS. Organização das Nações Unidas (ONU). Disponível em: $<$ http://www.unicrio.org.br/BibliotecaTextos.php?Texto=udhr.htm > . Acesso em abril/2007.

DISABILITY DISCRIMINATION ACT. Department for Education and Employment, The Stationery Office, 1995.

Discutindo a Paisagem. Organizado por Saide Kahtouni, Miranda Martinelli Magnoli, Yasuko Tominaga In Coleção Paisagem Aberta, vol. 1. São Carlos: RiMa, 2006.

DUARTE, Cristiane Rose de Siqueira ; COHEN, R. Afeto e Lugar: A Construção de uma Experiência Afetiva por Pessoas com Dificuldade de Locomoção. In Anais do Seminário Acessibilidade no Cotidiano. Versão em CD. Rio de Janeiro, 2004.

EMURB - Praça da Sé. Requalificação do Espaço Urbano. São Paulo, 2005. Apresentação de Power Point.

GEHL, Jan; GEMZOE, Lars. Novos Espaços Urbanos. Barcelona, Gustavo Gili, 2002.

GOLD, Philip Anthony. Nota técnica - Melhorando as Condições de Caminhada em Calçadas. In Seminário Paulistano de Calçadas - Calçadas seguras, responsabilidade de todos - São Paulo, 2003.

GOMES, Ricardo. Universal Design - Design for the Environment - Product development \& manufacturing. San Francisco, IDSA - Design and Industry Department, San Francisco State University. Summer session, 2003.

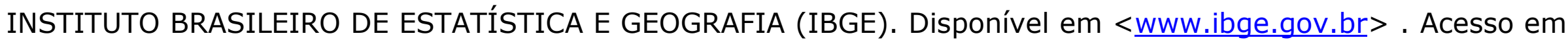
fev./2007.

JANUZZI, G. S. De M. e JANUZZI, N. Portadores de Necessidades Especiais no Brasil: uma reflexão a partir do Censo Demográfico 1991. São Paulo, Integração, 1994.

LAURIE, Michael. Introducción a La Arquitetura Del Paisaje. Barcelona, Gustavo Gili, 1983.

LOPES, Maria Elisabete. Metodologia de Analise e Implementação de Acessibilidade para Pessoas com Mobilidade Reduzida e Dificuldade de Locomoção. São Paulo, Tese de Doutorado, 2005. 
Município Acessível ao Cidadão - Unidade de Políticas Públicas - UPP. São Paulo, Fundação Prefeito Faria Lima - Centro de Estudos e Pesquisas de Administração Municipal (CEPAM), 2001.

NETO, Francisco Donatiello. Manual Técnico- Parques de Diversão. São Paulo, Associação das Empresas de Parques de Diversões do Brasil (ADIBRA), vol.1, 2007.

NOTÍCIAS. Disponível em: < http://www.anoregsp.org.br/noticia/detalha noticia.php?cd noticia=115 $>$. Acesso em abril/2007.

OLIVER, Fátima Corrêa; VAZ, Daniela; et all. Reabilitação no território: construindo a participação na vida social e o exercício da cidadania. São Paulo, Faculdade de Saúde Publica - Terapia Ocupacional - da Universidade de São Paulo, 2002.

ORGANIZAÇÃO INTERNACIONAL DO TRABALHO (ILO). Enciclopédia de Segurança e Saúde Ocupacional. Genebra, Suíça. Traduzido e digitado por Priscilla Cabral Flud (4a Edição). E-mail de Fábio Adiron enviado em 29/jul./2006.

ORNSTEIN, Sheila Walbe; LOPES, Maria Elisabete; CAMBIAGHI, Silvana Serafino. Brooklin acessível. São Paulo: Faculdade de Arquitetura e Urbanismo da Universidade de São Paulo, 2001. (mimeo/ caderno de projetos executivos).

PASSAGEM EM DOMICÍLIO. Disponível em < http://www.passagem-em-domicilio.com.br/terminal-barrafunda.asp>. Acesso em abril/2007.

PEREIRA, Marilu Mourão. Prevenção às deficiências: Alcances e limitações. Disponível em: <http://www.pedagobrasil.com.br/educacaoespecial/prevencaoasdeficiencias.htm> . Acesso em mar/2007.

PREFEITURA DA CIDADE DO RIO DE JANEIRO. Rio Cidade: o urbanismo de volta às ruas. Rio de Janeiro, Mauad, 1998. Organização Andre de Campos Alvarenga.

PREFEITURA DA CIDADE DE SÃO PAULO. Código de Obras do Município de São Paulo. Disponível em: 
<http://www6.prefeitura.sp.gov.br/secretarias/habitacao/legislacao/codigo de obras e edificacoes/0001>. Acesso em nov/2007.

PREFEITURA DA CIDADE DE SÃO PAULO. Disponível em:

$<$ http://www6.prefeitura.sp.gov.br/noticias/sec/deficiencia mobilidade reduzida/2005/12/0005> . Acesso em abril/2007.

PREFEITURA DA CIDADE DE SÃO PAULO. Disponível em:

$<$ http://www.prefeitura.sp.gov.br/portal/a cidade/noticias/audios/index.php?p=14012>. Acesso em jan/2007.

PREFEITURA DE SÃO PAULO - Passeio Livre. Disponível em:

$<$ http://ww2.prefeitura.sp.gov.br/passeiolivre/index.asp>. Acesso em mar./2007.

PREISER, Wolfgang; OSTROFF, Elaine. Universal Design Handbook. New York: McGraw-Hill, c.2001.

PRICE, Richard; STONEHAM, Jane. Making Connections - a guide to accessible greenspace. Londres, The Sensory Trust, 2001.

PROCESS: ARQUITECTURE. Lawrence Halprin. Tóquio: Process Architecture Publishing, n. 0 4, fev./1978.

Programa Brasileiro de Acessibilidade Urbana - Brasil Acessível. Ministério das Cidades- Secretaria Nacional de Transporte e da Mobilidade Urbana, 2006.

RELATÓRIO SOBRE A PREVALÊNCIA DE DEFICIÊNCIAS, INCAPACIDADES E DESVANTAGENS. Coordenadoria Nacional para Integração da Pessoa Portadora de Deficiência (CORDE) -. Niterói, 2004. Disponível em:

<http://www.mj.gov.br/sedh/ct/corde/dpdh/sicorde/Rel Pesquisa.pdf>. Acesso em abril/2007.

RESENDE, Ana Paula Crosara de. Todos Na Cidade: o direito a acessibilidade das pessoas com deficiência física em Uberlândia. Uberlândia. EDUFU, 2004.

SACKS, Oliver. Um Antropólogo em Marte. São Paulo. Companhia das Letras, 2006. 
SAMPACENTRO. Disponível em:

$<$ http://sampacentro.terra.com.br/textos.asp?id=106\&ph=2>. Acesso em out./2006.

SAMPA ONLINE. Disponível em: <http://www.sampaonline.com.br/reportagens/aljc2002jul18.htm>. Acesso em abril/2007.

SÃO PAULO (Município). Lei no. 10.365, de setembro de 1987. Disponível em: $<$ http://www.prefeitura.sp.gov.br/servicos/cidadaos/cidadania/leis municipais/index.php>.Acesso em out/2006. The Center for Universal Design - Environments and Products for All People. Disponível em:

$<$ http://www.design.ncsu.edu/cud/about ud/about ud.htm>. Acesso em ago./2006.

USP LEGAL. Disponível em <http://www.cecae.usp.br/usplegal>. Acesso em abril/2007.

VAZ, Daniela. Passeios no Parque - Acesso a Todos. São Paulo. Trabalho Final de Graduação (TFG), 2003.

YÁZIGI, Eduardo. O mundo das Calçadas - Por uma Política Democrática de Espaços Públicos. São Paulo, Imprensa Oficial do Estado de São Paulo, 2000. 


\section{Legislação.}

BRASIL. DECRETO NO 3.298, DE 20 DE DEZEMBRO DE 1999. Disponível em: <http://www.planalto.gov.br/CCIVIL/decreto/D3298.htm>. Acesso em fev./2008.

BRASIL. DECRETO NO 5.296 DE 2 DE DEZEMBRO DE $2004 . \quad$ Acesso em: http://www.planalto.gov.br/ccivil/ ato2004-2006/2004/Decreto/D5296.htm. Acesso em fev./2008.

BRASIL. LEI NO 7.405, DE 12 DE NOVEMBRO DE $1985 . \quad$ Disponível em: <http://www.planalto.gov.br/CCIVIL/LEIS/1980-1988/L7405.htm>. Acesso em fev./2008.

BRASIL. LEI NO 7.853, DE 24 DE OUTUBRO DE $1989 . \quad$ Disponível em: < http://www.planalto.gov.br/ccivil/LEIS/L7853.htm>. Acesso em fev./2008.

BRASIL. LEI $\mathrm{N}^{\circ}$ 10.048, DE 8 DE NOVEMBRO DE 2000. Disponível em: <http://www.planalto.gov.br/ccivil/Leis/L10048.htm>. Aceso em fev./2008.

BRASIL. LEI N $\mathrm{N}^{\circ}$ 10.098, DE 19 DE DEZEMBRO DE $2000 . \quad$ Disponível em: <http://www.planalto.gov.br/ccivil/LEIS/L10098.htm >. Acesso em fev./2008.

SÃO PAULO (Estado). DECRETO No 33.824, de 21 de setembro de 1991. Disponível em: <http://www.pge.sp.gov.br/centrodeestudos/bibliotecavirtual/dh/volume\%20i/deflei33824.htm>. Acesso em fev./2008.

SÃO PAULO (Estado). LEI No 3.710, de 04 de janeiro de 1983. Disponível em: $<$ http://www.cedipod.org.br/w6leiesp.htm >. Acesso em fev./2008.

SÃO PAULO (Município). LEI NO 9.199, DE 18 DE DEZEMBRO DE 1980. Disponível em: $<$ http://www6.prefeitura.sp.gov.br/secretarias/deficiencia mobilidade reduzida/legislacao/0006>. Acesso em fev./2008.

SÃO PAULO (Município). LEI No 11.228, de 25 de junho de 1992. Disponível em: <www.camara.sp.gov.br/noticias detalhe.asp?id=1124>. Acesso em fev./2008.

SÃO PAULO (Município). Decreto MUNICIPAL N. 33.329 de 1992. Disponível em: < www.pge.sp.gov.br>. Acesso em fev./2008. 
SÃO PAULO (Município). DECRETO No 45.904 de 19 de maio de 2005 . Disponível em: $<w w 2$. prefeitura.sp.gov.br/passeiolivre/pdf/Decreto.pdf>. Acesso em fev./2008.

SÃO PAULO (Município). Instrução Normativa / SAR / 01 / 2000. Disponível em: $<$ www.cedipod.org.br/INSTNORM.htm >. Acesso em fev./2008. 